NEVELÉSTUDOMÁNYI DOKTORI ISKOLA

OKTATÁSELMÉLET DOKTORI PROGRAM

KISS RENÁTA MÁRIA

\title{
A FONOLÓGIAI TUDATOSSÁG TECHNOLÓGIAALAPÚ MÉRÉSE 5-8 ÉVES GYERMEKEK KÖRÉBEN
}

$\mathrm{PhD}$ értekezés

Témavezető:

Prof. Dr. Csapó Benő

egyetemi tanár

Szeged,

2018 


\section{TARTALOMJEGYZÉK}

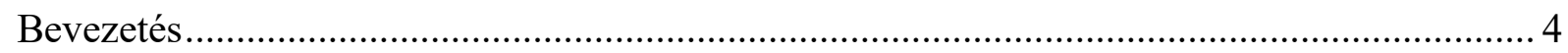

1. A fonológiai tudatosság fogalma és szerepe az olvasástanulás folyamatában ..................... 9

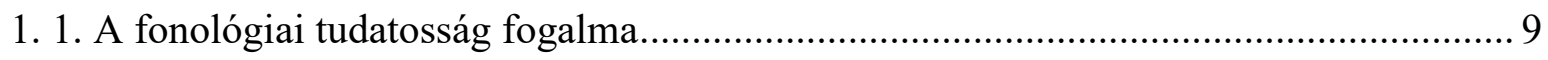

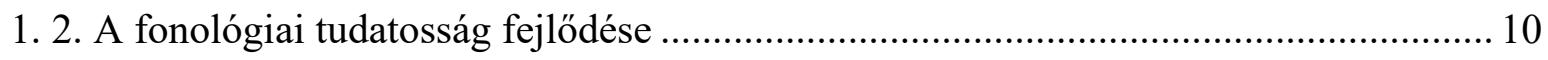

1.3. A fonológiai tudatosság és az olvasás kapcsolata .................................................. 20

2. A fonológiai tudatosság mérései lehetőségei - a hazai és nemzetközi mérési tendenciák

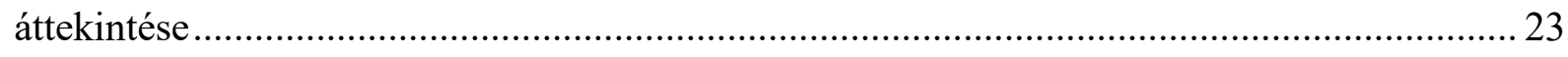

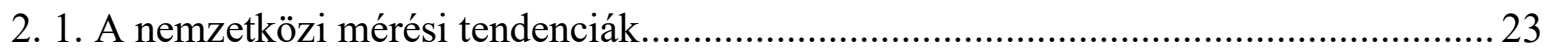

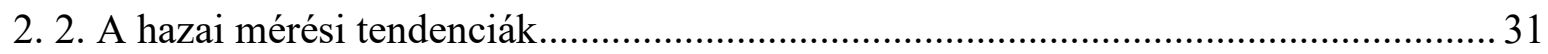

2. 3. A hazai és nemzetközi mérési tendenciák hasonlóságai és különbözőségei................ 34

3. A fonológiai tudatosság online mérési lehetőségei ......................................................... 36

3. 1. Az innovatív itemformátumok kidolgozása - áttérés az élőszavas tesztfelvételről az

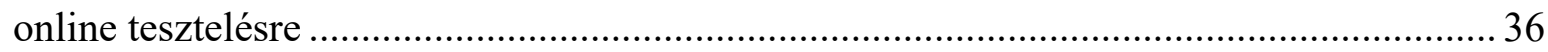

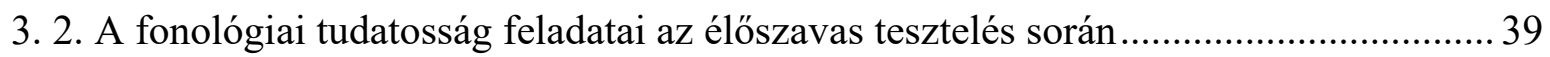

3. 3. A mérőbiztos szerepének megváltozása az online tesztelés során ............................... 41

3. 4. A közvetítő médium hasonlóságai és különbözőségei az óvodai és általános iskolai

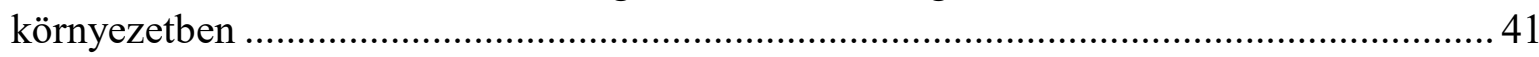

3.5. A dolgozat elméleti vonatkozásainak összegzése ................................................ 42

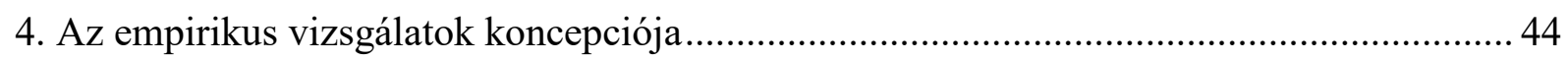

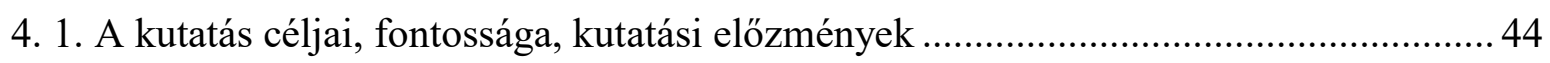

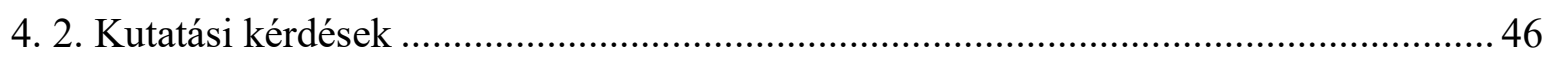

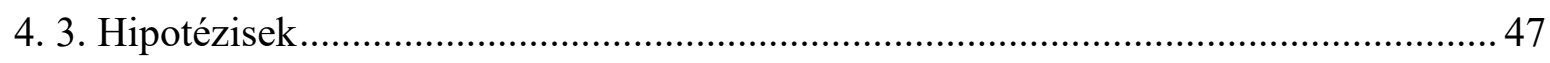

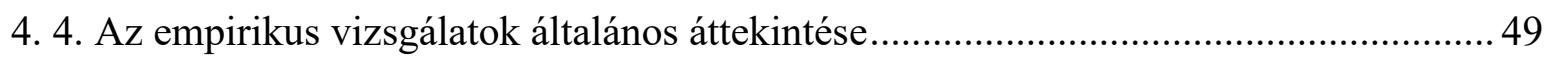

4.5. A fonológiai tudatosság mérőfeladatai online tesztelés során ....................................52

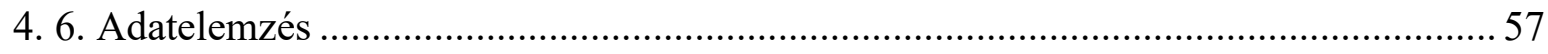

5. A fonológiai tudatosság online felületre adaptálható résztesztjeinek mérési lehetőségei az

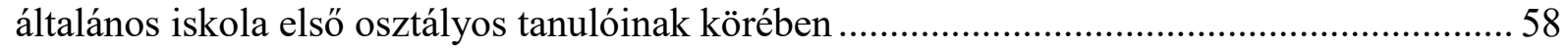

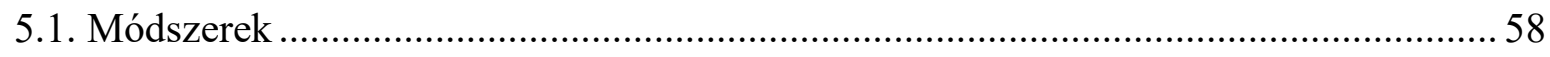

5. 1. 1. A vizsgálatban szereplö minta bemutatása.......................................................... 58

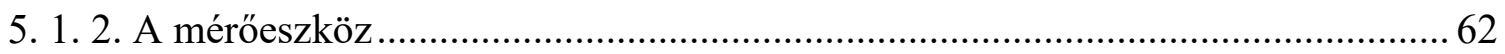

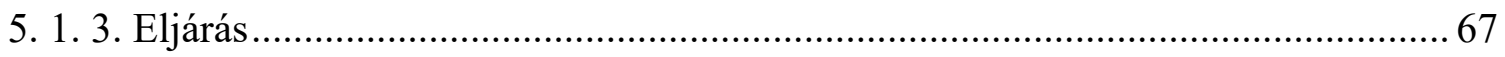

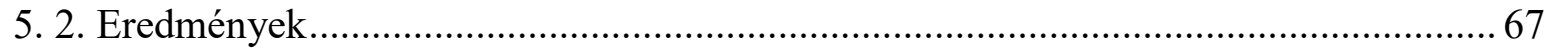

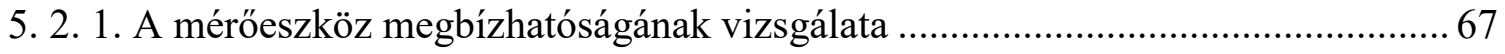

5. 2. 2. A feladatok nehézségének és a tanulók képességszintjének feltárása...................69 
5. 2. 3. A fonológiai tudatosság teszt belső konstruktumának vizsgálata .72

5. 2. 4. A tanulók teszten elért teljesítményének vizsgálata........................................... 78

5. 2. 5. A tanulók teljesítményének eloszlása nemük szerint ......................................... 79

5. 2. 6. A tanulók teljesítményének eloszlása életkoruk szerint........................................ 81

5. 2. 7. A fonológiai tudatosság teszt és a géphasználat teszt összefüggése általános iskola első osztályában.

5. 3. Az első osztályosok körében végzett vizsgálat eredményeinek összefoglalása.

6. A fonématudatosság teszt vizsgálata az általános iskola első évfolyamos tanulóinak körében

6. 1. Módszerek

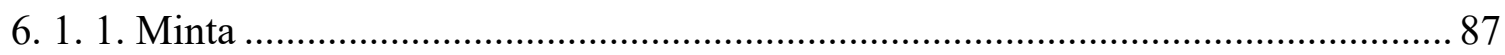

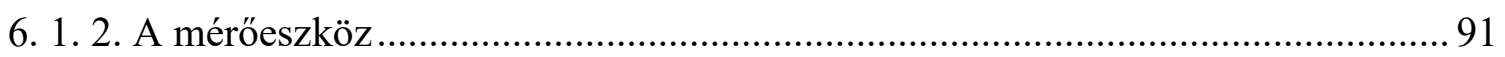

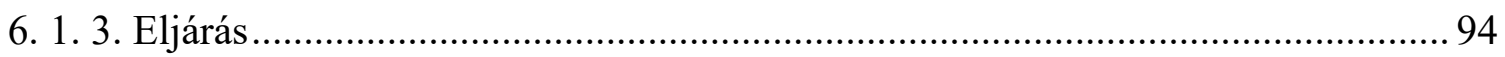

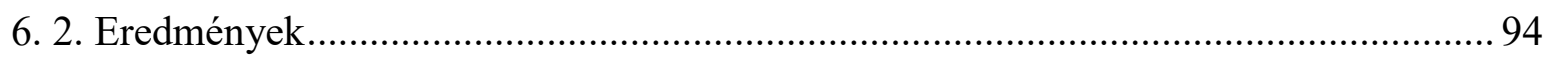

6. 2. 1. A mérőeszköz megbízhatóságának vizsgálata ................................................ 94

6. 2. 2. A feladatok nehézségi, és a tanulók képességszintjének feltárása ...................... 97

6. 2. 3. A fonématudatosság teszt belső konstruktumának vizsgálata............................... 99

6. 2. 4. A tanulók teszten elért teljesítményének vizsgálata............................................ 99

6. 2. 5. A tanulók teljesítményének eloszlása az életkoruk és nemük szerint ................ 101

6. 2. 6. A fonématudatosság teszt és a számítógép-használat teszt összefüggése az első

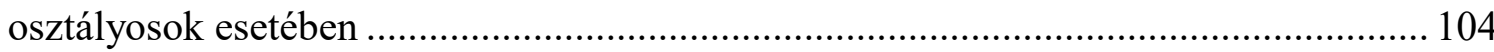

6. 3. Az első osztályos tanulók körében rögzített fonématudatossági teszt eredményeinek összefoglalása

7. A fonológiai tudatosság teszt adaptálható részeinek online tesztelése az óvodai korosztály körében 108

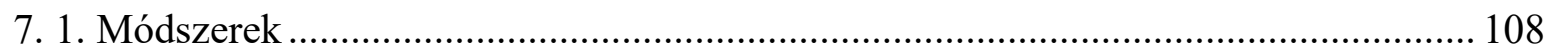

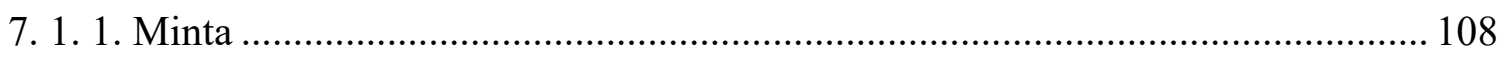

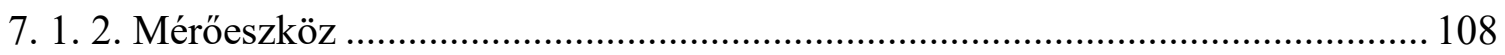

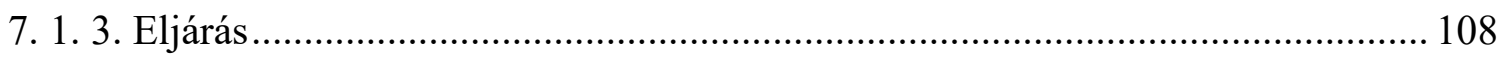

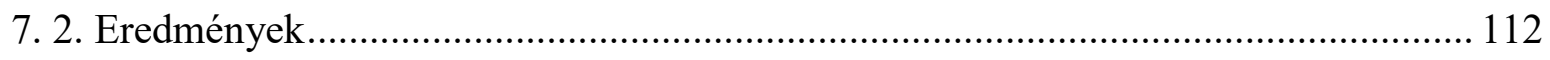

7. 2. 1. A mérőeszköz megbízhatóságának vizsgálata ................................................ 112

7. 2. 2. A feladatok nehézségének és a gyermekek képességszintjének feltárása ........... 114

7. 2. 3. A fonológiai tudatosság teszt belső konstruktumának vizsgálata ...................... 117

7. 2. 4. A gyermekek teszten elért teljesítményének vizsgálata ................................... 122

7. 2. 5. A gyermekek teljesítményének eloszlása az életkoruk és nemük szerint ........... 124

7. 2. 6. A fonológiai tudatosság teszt és a géphasználat teszt összefüggése óvodás korban 
7. 3. A fonológiai tudatosság óvodás korosztály körében végzett vizsgálat eredményeinek

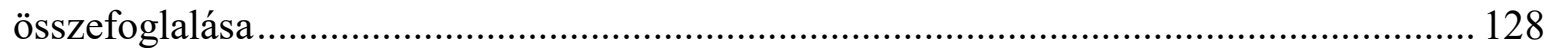

8. A fonológiai tudatosság fejlettségének vizsgálata az óvoda-iskola átmenet során............ 130

8. 1. A vizsgált minta és a két korosztályban rögzített közös itemek bemutatása ............. 130

8. 2. A fonológiai tudatosság fejlettsége az óvoda befejező és az iskola kezdő szakaszában

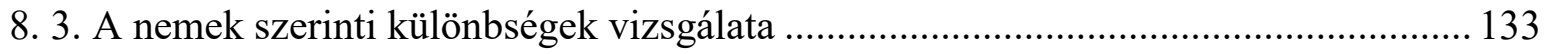

8. 4. A mintán belüli korcsoportok fejlettségének vizsgálata ........................................ 134

8. 5. A feladatok nehézségi, és a tanulók képességszintjének összehasonlítása az óvodai és

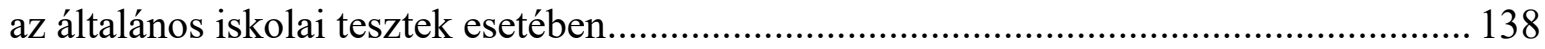

8. 6. Az óvodai és általános iskolai minta összehasonlítása során kapott eredmények

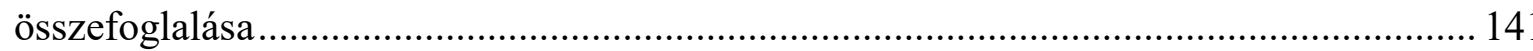

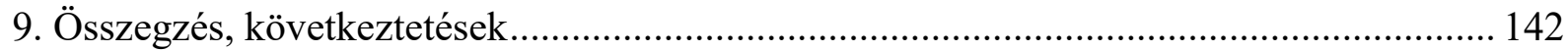

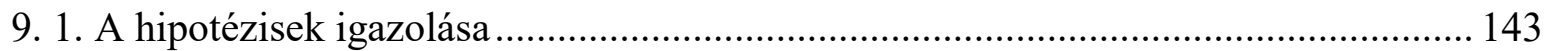

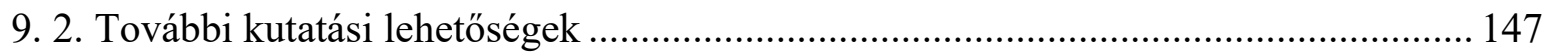

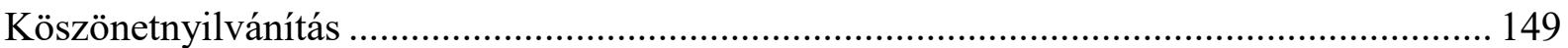

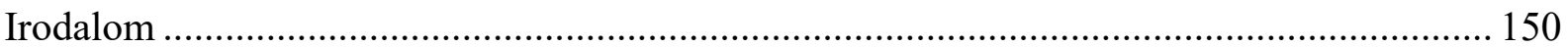

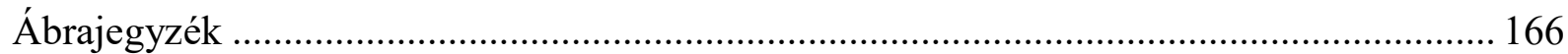

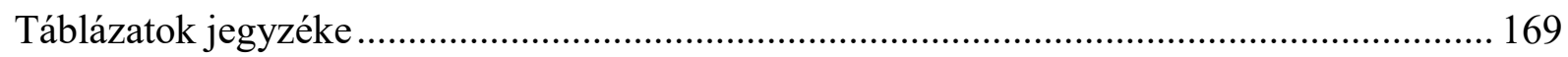

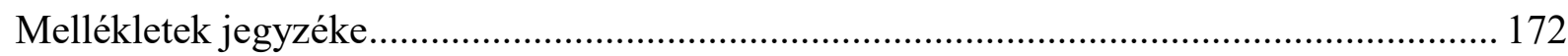




\section{BEVEZETÉS}

Az olvasás az egyén társadalomba való beilleszkedésének alapvető feltételei közé tartozik. Korai vizsgálata, a sikeres dekódolás, a fluens olvasás, valamint az értő olvasás megalapozását képező készségek, kognitív faktorok korai monitorozása elengedhetetlen. A képesség kialakulásának kezdeti szakaszát, valamint a későbbi olvasás sikerességét számos komponens határozza meg. Az olvasási képességet értelmezhetjük pszichikus rendszerként (Nagy, 2004), mely rendszerben minden összetevő müködése kihatással van egymásra és a kimenetre, ezért minden komponens megfelelö szintü müködése szükséges. Lonigan, Schatschneider, \& Westberg (2008) nézetei alapján az olvasási képesség kapcsán kiemelhetők a nyelvi készségekhez kapcsolódó komponensek is. Számos tanulmány bizonyította, hogy nyelvi készségek közül a fonológiai tudatosság meghatározó szerepet tölt be az olvasás elsajátításában (Hsuan, Tsai \& Stainthorp, 2018; Ruan, Georgiou, Song, \& Shu, 2018; Tibi \& Kirby, 2018; Blomert \& Csépe, 2012). A korai életkorban, óvodáskorban mért fonológiai tudatosság prediktív ereje mind a későbbi olvasási, mind a szövegértési képesség fejlődése kapcsán meghatározó (Lonigan, Burgess, \& Anthony, 2000; Phillips, Gormley, \& Anderson, 2016; Stanley, Petscher, \& Catts, 2018; Ziegler \& Goswami, 2005). A fonológiai tudatosságot a kutatók többsége gyüjtőfogalomnak tekinti (pl. Csépe, 2006), de a fogalom megközelítésében nagymértékü változatosság fedezhető fel mind a nyelvi egységek (pl. Torgesen \& Mathes, 2000), mind a nyelvi egységekkel végrehajtandó müveletek tekintetében (pl. Blachman, 1994), és ebből fakadóan a mérőeszközök konstruktumában is. A fonológiai tudatosság korai olvasáselsajátításban betöltött szerepe, a későbbi olvasásteljesítménnyel, szövegértéssel való kapcsolata révén, az olvasás kognitív faktorai közül a leginkább vizsgált területként jelenik meg (Blomert \& Csépe, 2012).

A kisgyermekkori nyelvi fejlődés és a fonológiai tudatosság jelentőségét feltáró tanulmányok számának növekedésével, a területet vizsgáló mérőeszközök száma is folyamatosan nő, a mérésre alkalmazott módszerek bővülnek, színesednek, egyre gyermekbarátabbá és objektívebbé válnak, alkalmazkodva, figyelembe véve a 21. század adta innovatív lehetőségeket. Számos olyan összefoglaló tanulmány, kötet jelent és jelenik meg, mely részletezi az olvasás ezen kognitív faktorának egyre sokszínűbb mérési módszertanát (pl. Chard \& Dickson, 1999; Józsa, Steklács, Hódi, Csíkos, Adamikné, Molnár, Nagy \& Szenczi, 2012; Muñoz, Valenzuela, \& Orellana, 2018; Palmer, Fleming, Horn, Butera, \& Lieber, 2018; Rathvon, 2004). A mérési módszerek és a mérőeszközök sokszínűsége nemcsak kizárólag a 
módszerek bővülésének, hanem a képesség definiálásának sokszínüségében is megmutatkoznak.

Napjainkig a fonológiai tudatosság mérőeljárásai többnyire szemtől szembeni adatfelvételen alapulnak, a mérési metódus folyamán esetenként megjelenik egy-egy olyan feladat, melyet elöre rögzített hanganyag kísért. Ezen hanganyagokat audiokazettára rögzítették, így minőségük egy idő után megkérdőjelezhetővé válik, illetve az audiokazettával segített mérések jellemzése során nem térnek ki a magnó elhelyezkedésére, a hangerőre, az esetleges beszürődő környezeti zajokra, melyek jelentősen befolyásolhatják a tesztek rögzítésének sikerességét. A technika fejlődésével az élőszavas tesztelési mód egyre inkább átalakul, az IKT (Információs és Kommunikációs Technológia) által támogatott lehetőségek előtérbe kerülnek. Megjelennek a számítógép segítette mérőeszközök, a számítógép/szoftver alapú fejlesztőjátékok is, melyek objektivitása, költség- és időtakarékossága jelentős. A szoftverek használata, pedagógiai alkalmazása jelentősen függ a vizsgálatot, fejlesztést végző pedagógus IKT-használattal kapcsolatos attitüdjétől. Az újszerü mérési lehetőségek az innovatív eszközöket alkalmazni, valamint a foglalkozásaiba integrálni tudó pedagógusokat (Zaranis \& Oikonomidis, 2015), valamint az IKT eszközöket szintén alkalmazni tudó tanulókat, gyermekeket kívánnak. Egy 2015 vizsgálat rámutatott arra, hogy mind a pedagógusok, mind a tanulók online teszteléshez való attitüdje pozitív, a megkérdezett pedagógusok 90\%-a, míg a diákok háromnegyede-négyötöde támogatja az innovatív tesztelési módot (Molnár \& Magyar, 2015). Molnár \& Pásztor (2015) kutatásukban rámutattak, hogy bár a diákok egér- és billentyüzethasználati képessége többfaktoros konstruktum, a kisiskolás tanulók mégis rendelkeznek az eszközhasználat képességével, mellyel lehetővé válik a korosztály online tesztelése. A kutatás a fiatalabb korosztály számára az egyszerübb műveletekre, a kattintásra, a nagyobb felületek mozgatására, valamint rövid, egyszerü válaszok gépelésére tesz javaslatot. Ezek az eredmények fontos támpontként szolgálnak az óvodás korosztály számára kidolgozott tesztek során. A 21. század gyermekpopulációjára jellemző, hogy a gyermekek az írás és olvasás elsajátítása előtt használnak IKT eszközöket (McKenney \& Voogt, 2012), illetve az is egyre elfogadottabb nézet, hogy ezektől az eszközöktől a gyermekeket tiltani lehet. Ollé (2013, p. 11.) szerint „ma már felesleges úgy tenni, mintha ez a folyamat lassítható vagy érdemben megakadályozható lenne”. A gyermekek számára az IKT eszközök széles skálája elérhető, a szülők okostelefonjától kezdve a laptopokon át akár az okostévéig. Az IKT eszközök közül mégis a tablet vagy az iPad az, mely a könnyű használhatósága és kompakt megjelenése miatt egyre nagyobb népszerüségnek örvend az óvodai korosztály körében (Beschorner \& Hutchsion, 2013; Marsh, Yamada-Rice, Bishop, Lahmar, Scott \& Plowman, 2015). 
Áttekintve a fonológiai tudatosság hazai és nemzetközi mérési módszereit, támaszkodva az IKT nyújtotta lehetőség előnyére, illetve figyelembe véve az ezirányú pozitív pedagógusi és tanulói attitüdöt és a 21. századi gyermekek informatikai ismeretét, a jelen dolgozat témáját szolgáló, online fonológiai tudatosság teszt kidolgozására vállalkoztunk, melyet óvodai és általános iskolai környezetben rögzítettünk. Egyrészt célunk egy olyan online mérőeszköz fejlesztése, mely a fonológiai tudatosság objektív és megbízható mérőeszközévé válhat az óvodai és általános iskolai környezetben. A munka hiánypótló, hiszen a jelenleg, ezen korcsoport számára alkalmazott mérőeszközök sokszínűsége, a mérőbiztos személyének különbözősége, a tesztrögzítési gyakorlatban szerzett tapasztalata, saját megfigyeléseink alapján, meghatározhatja a gyermekek teszten nyújtott teljesítményét. Továbbá megállapítható, hogy két személyes tesztfelvétel között is számos különbözőség léphet fel, mely természetesen nem kizárólag a pedagógus, mérőbiztos tesztfelvételi szokásaiból, hanem a gyermekek egyéni különbözőségeiből is adódhat, illetve szintén meghatározó tényezőként jelentkezhet a tesztet rögzítő személy segítségnyújtására, írányítására történő reakció (Vigotszkij, 2000; Cunningham \& Carroll, 2015). Carlisle (1990) arra is felhívja a figyelmet, hogy a fonológiai tudatosság teljesítményét jobban meghatározhatja a feladat típusa, mint a valóban megjelenő nyelvi tudás. Nézete szerint az onset-rhyme típusú feladatokon nyújtott jobb teljesítményt a preschool szakaszban gyakrabban megjelenő, azonos komponenst gyakorló feladatoknak is köszönhető. Éppen ezért a hazai mérési gyakorlatra vonatkoztatva szükséges lenne egy változatos teszkörnyezet kialakítása és változatos módszertanú feladatok beépítése, melyre kiváló lehetőséget nyújt az online tesztelés. A Szegedi Tudományegyetem Oktatáselméleti Kutatócsoportja az általános iskola 1-6. osztályos tanulói számára az olvasás pszichológiai, alkalmazási és diszciplináris dimenzióját vizsgáló a feladatbankot fejlesztett. A tesztfeladatok között, az olvasás pszichológiai dimenzióján belül, már megjelennek az adott korcsoport számára fejlesztett, fonológiai tudatosságot vizsgáló mérőfeladatok (Csapó, Józsa, Steklács, Hódi, \& Csíkos 2012; Józsa, Kiss, Nyitrai, Steklács, Szenczi \& Tóth, 2015), viszont a vizsgálat az óvodai korosztályra nem terjed ki. A dolgozat másik célja, a kidolgozott mérőeszköz müködésének és alkalmazhatóságának, valamint a gyermekek/tanulók fonológiai tudatosság teszten nyújtott teljesítményének vizsgálta az óvoda befejező, valamint az általános iskola kezdő szakaszában.

A dolgozat olyan kutatási kérdésekre igyekszik választ adni, minthogy valóban alkalmazható-e az óvodáskorban az online tesztelés, ezek a tesztek megbízhatóan vizsgálják-e a gyermekek képességeit, illetve, hogy az eddigi mérési gyakorlattal párhuzamosan azonos tendenciák jelenkeznek-e az online tesztelés esetében a gyermekek képességeinek vizsgálata 
során. A hazai mérési gyakorlat sokszínűsége, a fonológiai tudatosság mérésének eltérései, különböző tesztelési környezetbe való ültetése, illetve a kismintás mérések nem adnak egyértemü válaszokat a fonológiai tudatoság szubtesztjei közti kapcsolatra, a konstruktum belső szerkezetére. A dolgozat ezen hiányokat igyekszik pótolni. A munka elméleti hasznosságán kívül a kutatás gyakorlati, mindennapi pedagógiai vonatkozásai is relevánsak. Az eddigi mérési gyakorlatot kiegészítve, a mérőbiztosi szerepkör megváltozásával objektív, a fonológiai tudatosság széles spektrumát vizsgáló tesztbattéria jött létre. A pedagógusok objektív képet, kaphatnak a gyermekek/tanulók teljesítményéről, melyet kontextuális adatok egészítenek ki (Molnár, 2016). Ezáltal a pedagógusok kisebb erőbefektetéssel, mégis részletesebb adatokat kaphatnak a gyermekek teljesítményéröl, melyre megalapozottabb fejlesztési módszereket alakíthatnak ki. A pedagógus nem a mérés megvalósításában, hanem az arra épülő fejlesztés kialakításában játszik jelentős szerepet (Kiss, 2016).

A dolgozat nyolc részre tagolódik. Az első fejezet a fonológiai tudatosság fogalmát, és az olvasásban betöltött szerepét hangsúlyozza. A fejezet a fonológiai tudatosság fogalmának többféle változatát ismerteti, elhelyezi a képességet az olvasástanulás folyamatában, vizsgálja a korai szakaszban mért fonológiai tudatosság prediktív erejét, illetve a képesség fejlődését.

A második fejezet a fonológiai tudatosság mérési lehetőségeire tér ki mind hazai, mind nemzetközi szinten. A fejezet bemutatja, hogy különböző kontextusban, változatos módszerrel és mérőeszközök széles repertoárja által, milyen módon történik a fonológiai tudatosság különböző komponenseinek vizsgálata.

A harmadik fejezet a fonológiai tudatosság online mérési lehetőségeit emeli ki, részletezi a hazai fejlesztéseket. A fejezet kitér a szemtől szembeni és az online tesztelés módszertani különbségeire, valamint bemutatja a hagyományos, szemtől szembeni tesztelés során megjelenő különböző itemtípusokat. A fejezet részletezi a mérőbiztos szerepének megváltozását, illetve külön egységet szentel a közoktatás két vizsgált színterének, az óvodának és az általános iskolának online tesztelési módszertanára, kiemelve a két színtér online mérése közti hasonlóságokat és különbségeket is.

A negyedik fejezet az empirikus kutatások koncepciójával foglalkozik, kijelöli a kutatás célját. Kutatási kérdéseket és hipotéziseket fogalmaz meg, majd áttekinti a dolgozat további fejezeteiben megjelenő empirikus kutatásokat.

Az ötödik fejezet az online fonológiai tudatosság teszt első osztályosok körében végzett vizsgálatának eredményeit részletezi. A hatodik fejezet az általános iskola első osztályosainak körében végzett fonématudatosság teszttel dolgozik, míg a hetedik az óvodai korcsoportban végzett vizsgálatok eredményeit mutatja be. Az ötödik, a hatodik és a hetedik fejezet 
következetesen egy gondolatmenetre épül. A fejezetek elsőként a mérőeszköz megbízhatóságát vizsgálják, majd a feladatok nehézségét, a tanulók képességszintjét tárják fel. Mindhárom fejezet kitér a tanulók teszten nyújtott teljesítményének vizsgálatára, a teljesítmények nem és életkor szerinti eloszlására. Az ötödik és a hetedik fejezet a fonológiai tudatosság teszt belső konstruktumát, a képességen belüli rendezőelvet is vizsgálja.

A nyolcadik fejezet összeveti az óvodai és az általános iskolai eredményeket. Az elemzések kizárólag olyan itemekkel dolgoznak, melyek mindkét tesztben szerepelnek. A két mintát területi tagolódás alapján illesztettük, azaz az elemzésekben a szegedi óvodák és a szegedi általános iskolák adatai szerepelnek közel azonos mintaelemszámmal.

A dolgozatot a mérések eredményeit értelmező összegzés zárja le. A kutatások megvalósulását az Szegedi Tudományegyetem Oktatáselméleti Kutatócsoportja, az MTASZTE Képességfejlődés Kutatócsoportja, a Szegedi Tudományegyetem Neveléstudományi Intézete, valamint a Szegedi Tudományegyetem Juhász Gyula Pedagógusképző Karának Tanító- és Óvóképző Intézete támogatta. 


\section{A FONOLÓGIAI TUDATOSSÁG FOGALMA ÉS SZEREPE AZ OLVASÁSTANULÁS FOLYAMATÁBAN}

\section{1. A fonológiai tudatosság fogalma}

A nyelvek tanulmányzása magában foglalja a vizsgált nyelv fonológiájának, szintaxisának, szemantikájának, morfológiájának és pragmatikai tulajdonságainak vizsgálatát. A fonológia az adott nyelv hangkészletével foglalkozik, vizsgálja a hangok, hangsorok egymásra hatását, feltárja az emögött rejlő szabályokat, leírja a rendszerező elveket (Crystal, 2003). A szintaxis a nyelv grammatikai aspektusával, a mondatok, szerkezetek megformáltságával foglalkozik, a szematika a tényleges jelentést, a morfológia a szavak jelentéshordozó, jelentésmódosító egységeire, míg a pragmatika az egyének kommunikáció során megjelenő nyelvhasználatára fókuszál (Gillon, 2017).

Az olvasással összefüggésben leggyakrabban a metanyelvi tudatosság részét képező, fonológiai tudatosságot említik és vizsgálják. A fonológiai tudatosság meghatározásának számtalan változata él az irodalomban, pszichológiai, nyelvészeti, pedagógiai és logopédiai megközelítése egyaránt releváns. Fonológiai tudatosság gyüjtőfogalom, a szavak belső szerkezetéhez való tudatos hozzáférést és a szavak eltérő méretű egységeire (a magyarban szótagokra és hangokra) történő bontás képességét (Csépe, 2006), a nyelvi egységekhez való hozzáférést, valamint az ezekkel való müveletek elvégzésének képességét (Blomert \& Csépe, 2012; Torgensen, Wagner, \& Rashotte 1994; Gillon, 2004), illetve a szavakon belüli fonológiai egységek azonosítását és manipulációját lehetővé tevő készségeket magában foglaló készségeket (Hayes \& Flanigan, 2014) értjük alatta.

Graves, Juel, \& Graves (1998) és Konza $(2011$; 2014) a fonológiai tudatosság kapcsán kiemeli a metanyelv és a metanyelvi tudatosság fogalmát. Kassai (2001) szerint a metanyelvi tudatosságnak nincs egyértelmű meghatározása. Megállapítja, hogy a fogalom egyrészt jelentheti a nyelvvel való müveletvégzést, másrészt pedig a magáról a nyelvről való gondolkodást. Göncz (2003) szerint viszont a tudatosság ezen szintje már „lehetővé teszi, hogy a nyelvet ne csak közlések megértésére és megtételére használjuk, hanem maga a nyelvi rendszer (annak szerkezete és müködési szabályai) képezze a gondolkodás tárgyát" (Göncz, 2003, p. 6.). Lőrik (2006) szerint a metanyelvi tudatosság ,gyermekeknek és felnőtteknek az a képessége, amely lehetővé teszi, hogy a nyelvi tényeket önmagukban véve, tárgyként vizsgálják, és rajtuk különböző müveleteket végezzenek” (Lőrik, 2006. p. 6.). Ellis (2009) a metanyelvi tudatosság alatt a nyelvet irányító absztrakt nyelvi szabályokról való tudatosságot, 
illetve a nyelvi elemzőképességet érti, Bruinsma (2003) szerint már a metanyelvi tudatosság része a beszéd különböző méretü nyelvi egységekre bontása.

Összességében elmondható, hogy a felsorolt nézetek mind azon szempontot támasztják alá, mely szerint a fonológiai tudatosság: (1) egy kiemelkedő metanyelvi készség, (2) a nyelv a gondolkodás tárgyaként jelenik meg, és (3) a nyelvi egységekkel történő müveletvégzés dominál. A képesség átmenet a spontán beszédelsajátítás, valamint az olvasástanulás- és tanítás között. A fonológiai tudatosság müveleteinek, valamint ezek kialakulásának ás fejlődésének áttekintését a következő fejezetek tárgyalják.

\section{2. A fonológiai tudatosság fejlődése}

Goswami (2002), Barbour, Keafer, \& Scott (2003), valamint Stackhouse, Wells, Pacoe, \& Rees (2002) szerint a fonológiai tudatosság fejlődésében két fő szint különböztethető meg: a fonológiai és a fonémaszint. A fonológiai szint rímképzésből, szótagokra bontásból, valamint a szótagkezdet és a rím különválasztásából áll. A fonématudatosság már magába foglalja a manipulációs készségeket is, a szavak hangokra bontását (szegmentálását), a hangokból történő szóalkotást (szintézist), az egyes fonémák szóban betöltött helyének megállapítását (izolálását), a hangok egy adott szón belüli cseréjét, vagy azok elhagyását (törlését) (Chard \& Dickson, 1999). Blachman (1994) a szavak belső egységeivel való manipulálást, Lőrik \& K. Jancsó (2009) a szótag, rím és fonéma szintü müveletvégzést, míg Torgesen \& Mathes (2000) már csak a fonémaszinten történő müveletvégzést érti fonológiai tudatosság alatt. Cunningham \& Carroll (2013) implicit (szótagolás és rímalkotás) és explicit (fonéma) szinteket definiál, Konza (2011) a szókezdet és a rím szétválasztásának képességeként definiálja a fonológiai tudatosságot. A felsorolt elméletek zöme egyetért abban, hogy a fonológiai tudatosság két szintje különíthető el, melyet a nyelvi egység nagysága határoz meg. A fejlődés első szakaszában a szótagok és rímek felismerése, azonosítása, míg a második szakaszban a hangokkal történő tudatos manipuláció jelenik meg.

A fonológiai tudatosságról rendelkezésre álló szakirodalom szerint az egyén nyelvi fejlődése során a szótag szintű fonológiai tudatosság már az óvodás korban megjelenik (Chard \& Dickson 1999, Ziegler \& Goswami 2005). A fonématudatosság bizonyos „egyszerübb” részkészségei, mint a beszédhangok azonosítása vagy differenciálása szintén ebben az életkori szakaszban alakul ki. Fontos megjegyezni, hogy az angolszász kultúrában a beiskolázás már öt éves korban megkezdődik, a gyermekek az óvodai oktatás utolsó évében, az úgynevezett preschool szakaszban az oktatás keretei belül kezdik megismerni a betüket. Magyarországon 
nem jellemző a hasonló korú gyermekek ezirányú célzott oktatása, természetesen ez nem jelenti azt, hogy a magyar óvodákban nem találhatók olyan gyermekek, akik spontán módon és/vagy egyéb, nem intézményes keretek között tesznek szert a képességre. Az angol és magyar nyelvü gyermekek fonológiai tudatosságának fejlődésére, valamint a fejlődés hasonlóságaira és különbözőségeire hívja fel a figyelmet Jordanidisz (2011) a kétnyelvű gyermekek fonológiai tudatosságát vizsgáló tanulmányában. Jordanidisz (2011) a fejlődési különbségeket egyrészt a fonológiai tudatosság fejlődésének különbözőségeivel, másrészt a fonológiai szerkezet különbségeivel, harmadrészt pedig azzal magyarázza, hogy a két kultúra más időpontban emeli be az olvasástanítást az oktatás folyamatába. Jordanidisz összefoglalójában (1. táblázat) a fonológiai tudatosság fejlődése során megjelenik a magyar nyelvben explicit nem értelmezhető onset (szókezdet) és rime (fordításában rím). Az onset és a rime egy szótagon belül megjelenő két dimenziót tükröz. Az onset a szótagkezdő hang, míg a rime egy magánhangzót tartalmazó, szókezdő hangot követő egység (Cuetos, Martínez-García, \& Suárez-Coalla, 2018; Graham, Harris, \& Adkins, 2018) (pl. a cat egyszótagú szó esetében a c az onset, míg az at a rime szerepét tölti be). Az angol és a magyar nyelvben összevetése kapcsán, az említett két nyelvi egység kivételével, azonos komponensek jelennek meg, viszont a komponensek kialakulásának egymáshoz viszonyított időpontja, fejlődésének üteme eltérő. Jordanidisz (2011) összehasonlítása szerint (1. táblázat) az angolban először a rímtalálás, majd a szótagszegmentálás és a -szintézis, míg a magyarban előbb a szótagszegmentálás és -szintézis, majd ezt követően a rímtalálás jelenik meg. Mindkét esetben a sort a fonémákkal történő manipulálás követi. A fonológiai szerkezet különbségeinek bemutatása során megjelenik a nyelvtípusok osztályának két jellemzője: az angol nyelv izoláló, valamint a magyar nyelv agglutináló jellege, illetve ehhez kapcsolódóan olyan szempontok jelennek a táblázat további soraiban, melyek jelentősen megnehezíthetik a szavakon belüli manipulációs folyamatok sikerességét (pl. mássalhangzó-torlódás, több szótagú vagy összetett szavak megjelenési aránya). Az olvasás oktatásának különbségeit már részben érintettük, de Jordanidisz (2011) összefoglalója is kiemeli, hogy az angol nyelvterülettel szemben, ahol már 5 éves korban megjelenik az intézményi keretek közti olvasástanítás, a magyar gyermekek intézményes keretek között 1-2 évvel később, 6-7 évesen kezdik el elsajátítani az írás és olvasás alapjait. 
1. táblázat. Az angol és magyar nyelv összehasonlitása a fonológiai tudatosság szemszögéböl (Forrás: Jordanidisz, 2011)

\begin{tabular}{|c|c|c|}
\hline & Angol & Magyar \\
\hline $\begin{array}{l}\text { A fonológiai tudatosság } \\
\text { fejlődésének különbségei } \\
\text { (Goswami, 2003; Jordanidisz, } \\
\text { 2010; Rudginsky \& Haskell, } \\
\text { 2002; Kassai, 1999) }\end{array}$ & $\begin{array}{l}\text { - Rímtalálás } \\
\text { - Szótagok szegmentálása és } \\
\text { szintézise (blending) } \\
\text { - Szótagkezdet és rím } \\
\text { szegmentálása } \\
\text { - Fonéma izolálás } \\
\text { - Fonémák szegmentálása és } \\
\text { szintézise (blending) } \\
\text { - Fonémákkal történő } \\
\text { manipulálás }\end{array}$ & $\begin{array}{l}\text { - Szótagok szegmentálása és } \\
\text { szintézise (blending) } \\
\text { - Rímtalálás } \\
\text { - Szótagokkal történő } \\
\text { manipulálás } \\
\text { - Fonéma izolálás } \\
\text { - Fonémák szegmentálása és } \\
\text { szintézise (blending) } \\
\text { - Fonémákkal történő } \\
\text { manipulálás (a hivatalos } \\
\text { olvasástanulás megkezdése } \\
\text { előtt) }\end{array}$ \\
\hline $\begin{array}{l}\text { A fonológiai szerkezet } \\
\text { különbségei }\end{array}$ & $\begin{array}{l}\text { - Izoláló nyelv szintetikus } \\
\text { jegyekkel } \\
\text { - Az egy szótagos szavak } \\
\text { aránya a szókészletben: 63\% } \\
\text { - Két-három mássalhangzó } \\
\text { kombinációja a } \\
\text { szótagkezdetben gyakori } \\
\text { - A diftongusok előfordulása } \\
\text { gyakori (a magánhangzók } \\
\text { 40\%-a) }\end{array}$ & $\begin{array}{l}\text { - Agglutináló nyelv } \\
\text { - Az egy, szótagos szavak } \\
\text { aránya a szókészletben: } 36 \% \\
\text { (Tarnóczy, 1995) } \\
\text { - Két-három mássalhangzó } \\
\text { kombinációja a } \\
\text { szótagkezdetben ritka } \\
\text { - Nincsenek diftongusok } \\
\text { (egyes nyelvjárások } \\
\text { kivételével) }\end{array}$ \\
\hline $\begin{array}{l}\text { Az olvasás oktatásának } \\
\text { különbségei }\end{array}$ & 5 éves korban kezdődik & 6-7 éves korban kezdődik \\
\hline
\end{tabular}

A fonológiai tudatosság által takart készségek megjelenését az óvodába lépéstől az óvoda befejezéséig az 2. táblázat foglalja össze. Farrall (2012) megközelítéséből is látszik, hogy a gyermekek egy spontán folyamat részeként az óvodába lépéskor már a szavak szintjén manipulálnak, ebben a korcsoportban már megjelenik a szótudatosság. Az életkor előrehaladtával elsőként felismerik az egyre kisebb nyelvi egységeket (kiscsoportban a szótag és rímtudatosság dominál), majd az óvoda kimeneti szakaszához, befejező évéhez közeledve a a hangok szókezdő helyzetben történő azonosítása, a rövid szavak hangokra bontása jelenik meg, illetve erre épülve, ezzel párhuzamosan a hangokkal történő manupilálás. Az óvodás 
gyermekek nagycsoport végére képesek szókezdő pozícióban lévő beszédhangok leválasztására, hangok szintetizálására.

2. táblázat. A fonológiai tudatosság fejlödése óvodáskorban (Forrás: Farrall, 2012)

\begin{tabular}{|c|c|c|}
\hline \multirow[t]{7}{*}{ Kiscsoport } & Készség & Példa/feladat \\
\hline & Szótudatosság & $\begin{array}{l}\text { A mondatban hallott minden } \\
\text { szóra tapsolj egyet! }\end{array}$ \\
\hline & Szótagtudatosság & A szóban hallott minden \\
\hline & & szótagra tapsolj egyet! \\
\hline & Rímek azonositása & Rímelnek a következö szavak? \\
\hline & Rímprodukció & Mondj egy szót, amely rímel a \\
\hline & & ház szóval! \\
\hline \multirow[t]{9}{*}{ Nagycsoport vége } & Azonos szókezdö beszédhangok & Ugyanúgy/ugyanazzal a \\
\hline & azonositása & hanggal kezdödnek a következö \\
\hline & & szavak? \\
\hline & A szókezdö beszédhangok & Mondd meg, milyen hanggal \\
\hline & leválasztása & kezdödik az a szó, hogy csengö! \\
\hline & A magánhangzó-mássalhangzó & $|\dot{a}+g /=\dot{a} g| f+a \mid,=f a$ \\
\hline & vagy mássalhangzó- & \\
\hline & magánhangzó mintázatok & \\
\hline & szintetizálása & \\
\hline
\end{tabular}

A fonológiai tudatosság bár különböző nyelvi szinteken (szótag és fonémaszint), de azonos mentális műveletekkel operál. Négy mentális müveletet különíthetünk el: (1) a szegmentálás, azaz a különböző nagyságú nyelvi elemekre történő bontása, (2) a szintézis, azaz a nyelvi egységek szavakká történő összefüzése, (3) az izolálás, azaz az adott nyelvi egység elkülönítése a szóból, valamint (4) a nyelvi egységekkel történő manipulálás. Józsa et. al. (2012) értelmezésében a fonológiai tudatosság fejlődése során a következő szakaszok/készségek különíthetők el: (1) szótagok szegmentálása és szintézise, (2) rímtalálás, (3) szótagokkal történő manipulálás, (4) fonémák izolálása, (5) fonémák szegmentálása és szintézise, (6) fonémákkal történő manipulálás. Meglátásuk szerint az említett készségek bár eltérő időpontban jelennek meg, de részben párhuzamosan fejlődnek. Ezen részképességek 
elsajátításának sorrendjét illetően hazai, nagy mintaelemszámú, reprezentatív kutatást nem találtam.

Jordanidisz (2009) az amerikai NILD Phonological Awareness Skills Survey (Barbour, Keafer, \& Scott, 2003) magyar adaptációján keresztül 22 gyermeket, 9 részképességen keresztül vizsgált. Tesztje minden egysége 5 feladatot tartalmazott. A fonológiai tudatosság vizsgált részkészségei között szerepelt a rímképzés, a szótagelhagyás, a szókezdő hang vagy hangcsoport leválasztása, a szótagszintézis, a beszédhang-izolálás, a beszédhangszintézis, beszédhang-szegmentálás, a hosszú beszédhang azonosítása, valamint a beszédhangmanipuláció. A tesztek felvétele első osztály elején, valamint második osztály elején történt, szemtől szembeni, egyéni rögzítés során. A vizsgálat eredményei alapján, első osztály elején Jordanidisz (2009) a gyermekek részteszteken nyújtott átlagteljesítménye alapján következő fejlettségi sorrendet állapította meg: (1) szótagszintézis, (2) szótagelhagyás, (3) beszédhangizolálás, (4) szókezdő beszédhang-hangcsoport leválasztása, (5) beszédhang-szegmentálás, (6) beszédhangszintézis, (7) rímkeresés, (8) hosszú beszédhang azonosítása, (9) beszédhangmanipuláció. Az angol nyelvü vizsgálatok során Karmeenui \& Simmons (1990) a szegmentálás és a szintetizálás kapcsolatára világított rá. A két műveletet szinte egymás előfeltételeiként értelmezi, a gyermeknek először a szegmentálást kell magabiztosan elsajátítania, majd ezután adhatók számára olyan feladatok, melyek a szintetizálást, azaz a kisebb egységek összefüzését kérik. Yopp (1992) a szegmentálást nehezebb feladatnak véli, Chappel, Stephens, Kinnison, \& Petigrew (2009) a fonológiai tudatosság részképességei közül a fonémaszegmentálást a legnagyobb kihívásként jellemzi, míg Konza (2011) a szintetizálást és a szegmentálást reciprok müveletnek tartja. Abban egyetérhetünk, hogy a manipulációhoz, müveleti szinthez köthető feladatok egyéni sikeressége nagymértékben függ a nyelvi és az általános kognitív funkciók érettségétől és müködésétől (Gósy, 2007).

A fonológiai tudatosság fejlődése nyomon követhető a feladatok nehézségi szintjének, összetettségének módosulásával, módosításával is. A fonológiai tudatosságot vizsgáló feladatok nehézségi szintje nemcsak az egyes nyelvi egységek mérete, valamint a végrehajtandó műveletek (azonosítás, differenciálás, manipuláció/műveleti szint) komplexitása mentén közelíthető meg, hanem változtatható a szógyakoriság (gyakorisági szempontból magas és alacsony értékü szavak) és a szemantikai értelmezhetőség (valódi és álszavak), valamint a keresett hang/hívóhang szóbeli pozíciója (szóeleji, szóbelseji, szóvégi), minősége (zöngésség, időtartam, képzéshely, képzésmód) és környezete (magánhangzó előtti, mássalhangzó előtti, magánhangzó utáni, mássalhangzó utáni, két magánhangzó közötti, két mássalhangzó közötti) alapján (Crystal, 2003; Kassai, 2006; Molnár, 1989, Papp, 1966; Siptár, 2006; Zsigri, 2006). A 
fonológiai tudatosság mérőfeladatainak nehézségi szintjét befolyásoló főbb tényezőket a 3. táblázat foglalja össze az általános szempontok mentén, míg a kizárólag csak a fonémaszintre vonatkozó szempontokat az 4. táblázat tartalmazza.

Az általános szempontok (3. táblázat) között szereplő nyelvi szintek, valamint az azonosítási/differenciálási és müveleti szintek szerinti tagolódást, ezen szintek egymáshoz viszonyított nehézségét, illetve az egyén fejlődése során tapasztalható kialakulását és fejlődését már bemutattuk, a feladatok kapcsán megjelenő szógyakoriság és szemantikai értelmezhetőség kérdésköre viszont még érintetlen maradt. A szógyakoriság, akár különböző ortográfiájú nyelvek összehasonlítása során is, gyakran elötérbe kerül mind a szófelismerés és a dekódolás (Csépe, Győri, \& Ragó, 2008), mind a betüzés (Marinelli, Romani, Burani, \& Zoccolotti, 2015) kapcsán. Csépe (2014) egy nyelvközi összeszehasonlító vizsgálat elvégzésének eredményeként megállapította, hogy a fonológiai tudatosság minden ortográfiában kulcseleme a dekódolás fejlettségének. Tanulmányába öt nyelvet vont be, az erősen transzparens finn és magyar, a közepesen transzparens holland és a legkevésbé transzparens portugál és holland nyelvet. Juhász \& Kálló (2017) tanulmányukban megállapítják, hogy egy szeriálisterjedelem-észlelésre épülő feladatok esetében, azaz a szó hosszúságának, szótagszámának megállapítása során, az azonos szóhosszúság mellett befolyásoló tényezőként jelenhet meg a szógyakoriság is. Megállapítják, hogy a gyermekek az általuk jobban ismert szavakat, vagy az olyanokat, melyet pozitív érzelmi hatással felruházottak, rövidebbnek érzékelhetik. A tesztek kialakítása során a gyakorisági szempontból magas, azaz a gyermekek többsége számára ismert szókészlet felől, a gyakorisági szempontból alacsonyabb értékü példa/hívószók felé haladva, nehezíthetők.

A szavak ismerősségének kritériuma kizárható álszavak alkalmazásával. A valid magyar álszóteszt (Racsmány, Lukács, Németh, \& Pléh, 2005) megfelelő álszókészletet nyújt az ilyen típusú tesztek kialakításához. Az álszavak megfelelnek a magyar nyelv fonológiájának, fonotaktikai strukturájának, csupán szemantikai értelemmel nem rendelkeznek. Az álszavak a nemzetközi vizsgálóeljárások részét képezik már az 1980-as évektől, bár ezek a vizsgálatok főként az értelmetlen szavak ismétlésére kérték a gyermekeket. Brady, Schankweiler, \& Mann (1983), valamint Kamhi \& Catts (1986) rámutattak arra, hogy az értelmetlen szavak ismétlése és a későbbi olvasási teljesítmény közti szoros kapcsolat áll fenn, továbbá Campbell \& Butterwort (1985) valamint Snowling \& Hulme (1989) a diszlexiával küzdő gyermekek álszóismétlési teszten nyújtott gyenge teljesítményét emelte ki. A szótag és fonémaszám növelésével a feladat nehézségi szintje tovább növelhető. A szóhosszúsági hatás vizsgálata főként a pszichológiai és munkamemóriát vizsgáló mérőeljárások során, már az 1970-es évektől nyomon követhető (Badelley, Thomson \& Buchanan, 1975; Ellis \& Hennelly, 1980), míg 
hazánkban a fonológiai tudatosság kapcsán Jordanidisz (2009) az amerikai NILD Phonological Awareness Skills Survey (Barbour et al. 2003) adaptálása kapcsán említette meg, hogy a feladtok nehézségi szintjét a fonémák, illetve szótagok számának növelésével, valamint bonyolultabb fonémakapcsolatok beemelésével érte el.

\section{3. táblázat. A fonológiai tudatosság méröfeladatainak nehézségi szintjét befolyásoló tényezök}

\begin{tabular}{ll}
\hline Általános szempontok & \\
\hline A fonológiai tudatosság belüli nyelvi szintek & fonéma \\
& szótag \\
A fonológiai tudatosságon belüli feladatok, műveletek & felismerés, differenciálás \\
& szintézis \\
& szegmentálás \\
Szógyakoriság & törlés \\
& gyakorisági szempontból magas értékü \\
& "közepesen gyakori" \\
Szemantikai értelmezhetőség & gyakorisági szempontból alacsony értékü \\
& valódi szavak \\
A szavak hosszúsága & álszavak \\
& szótagszám \\
\hline
\end{tabular}

A fonématudatosságra fókuszáló feladatok esetében további, a feladatok nehézségi szintjét befolyásoló tényezők emelhetök ki (4. táblázat). Kiss, Hódi \& Török (2015) a képzés helyének és módjának, valamint a fonéma szóbeli pozíciójának szerepét vizsgálták egy saját készítésű fonológiai tudatosság teszt példaanyagán és eredményein keresztül. Eredményeik arra mutattak rá, hogy a vizsgált, 1-4. osztályos populáció esetében a faktoranalízis fő rendezőelve a képzés helye és módja köré szerveződött. A fonéma szóbeli pozíciójának szerepére a dolgozatban már kitértünk, érintettük a fonológiai tudatosság fejlődése kapcsán. A keresett fonéma környezete, az esetleges hasonulások, valamint a mássalhangzó torlódások szintén meghatározó tényezőként jelentkezhetnek, nehezíthetik a hívóhang azonosítását, differenciálását. 


\begin{tabular}{|c|c|}
\hline Szempontok & \\
\hline \multirow[t]{6}{*}{ A keresett fonéma környezete } & magánhangzó előtti (_v) \\
\hline & mássalhangzó előtti (_c) \\
\hline & magánhangzó utáni (v_) \\
\hline & mássalhangzó utáni (c_) \\
\hline & két magánhangzó közötti (v_v) \\
\hline & két mássalhangzó közötti (c_c) \\
\hline \multirow[t]{3}{*}{ A keresett fonéma szóbeli pozíciója } & szó elején \\
\hline & szó belsejében \\
\hline & szó végén \\
\hline \multirow[t]{5}{*}{ A hívóhang minősége } & zöngésség \\
\hline & időtartam \\
\hline & képzéshely \\
\hline & képzésmód \\
\hline & hangkihallás (sorrendi észlelés) \\
\hline
\end{tabular}

A hívóhang minősége kapcsán részletes áttekintést az 5. táblázat ad, hiszen a hangok akusztikai és ejtésbeli hasonlósága, a képzés helye és módja szerinti hasonlósága, illetve két hang képzési helyének közelsége szintén befolyásolja a feladatok nehézségét (Meixner \& Justhné, 1967, Meixner, 1993). A hasonló hangok kihallása és hasonló betűk tanítása során felléphet a homogén gátlás jelensége. A homogén gátlás fogalma szerint a hasonló elemek egyidejü tanulása memorizálási nehézségekhez vezethet (Ranschburg, 1939). Meixner \& Justhné (1967) munkájukban a hármas asszociáció elvét követve világítanak rá a betü vizuális képe, a hang akusztikus képe, valamint a hang beszédmotoros emlékképe alapján megvalósuló hasonlóságokra (5. táblázat). Munkájuk alapján könnyen felállítható betük optikai hasonlósága, mely áttekintés segítséget nyújthat a későbbi feladatok kialakítása során is, illetve tovább vezethet a dolgozat témáját nem képező vizuális differenciálás problémájára is, mely később az olvasás kiemelt kognitív faktorának, a betü-beszédhang megfeleltetésnek, illetve az írás és olvasás elsajátításának kardinális szempontjává válik. Az optikai hasonlóság egyaránt érinti a magán- és mássalhangzókat is. A magánhangzók esetében ez főként a rövid és hosszú hangot jelölő betükön szereplő ékezetek szerepében merül ki, illetve, a betük felett megjelenő szimpla és dupla ékezet (pl. u-ü) esetében jelentős. A mássalhangzók esetében ez a hasonlóság többrétü, 
hiszen nem mindegy, hogy írott vagy nyomtatott, illetve kis- vagy nagybetük összehasonlításáról van szó. Jelen összehasonlítás a nyomtatott kisbetük kérdésére tér ki. Ezek közül is leginkább az irányultság kérdésköréhez is kapcsolható $\mathrm{p}$ és d betűk, valamit az irásmódjukban, betüvezetésükben minimálisan eltérő $\mathrm{b}$ és $\mathrm{d}$ betűk töltenek be kiemeltem fontos szerepet. Hazánk egyik közkedvelt olvasástanítási módszere, mely többek közt a homogén gátlás, valamint az említett hármas asszociációt elvét is követi, a kis és nagybetűk írását együttesen, de a hasonló betűket szeparáltan tanítja, felállítva ezzel egy, az említett szempontokat kiemelten szem előtt tartó betűtanítási sorrendet, illetve folyamatos gyakorlatokat épít be a tanultak szilárdítására (Meixner, 2012).

A hangok akusztikus és beszédmotoros hasonlóságát a hangok képzési helyének és módjának közelsége és hasonlósága alapján jellemezhetjük. A magánhangzók esetében a hasonlóság mértékét a nyelvállás (felső, középső, alsó, legalsó nyelvállású hangok), az ajakmüködés (ajakkerekítéses, ajakréses), valamint a képzés helye határozza meg (elől- vagy hátulképzett). A mássalhangzók esetében ugyanezen hasonlósági szempontok a képzés helye (ajakhang, foghang, ínyhang, gégehang) és a képzés módja (zárhang, réshang, zás-réshang, oldalsó pergőhang) szerint valósulnak meg. Az akusztikai és ejtésbeli hasonlóság esetén a mássalhangzók hasonlósága megjelenhet azonos helyen és módon képzett zöngés és zöngétlen hangok között (zöngés-zöngétlen párok; $\mathrm{f}-\mathrm{v}, \mathrm{t}-\mathrm{d}, \mathrm{sz}-\mathrm{z}, \mathrm{k}-\mathrm{g}$ ), eltérő módon. Az orális-nazális párok esetében azonos helyen képzett zönzgés hangok között gy-ny, valamint szintén azonos helyen képzett zöngés és zöngétlen hangpárok között $(p-m, t-n)$.A lágyított hangok esetében képzés helye szerint azonos zöngés és zöngétlen párok ( $g y-j$ és ny-j párok), a képzés módja szerint megegyező, ám a képzés helye szerint eltérést mutató zöngés, (pl. gy-d), valamint a képzés helye szerint megegyező, de a képzési módban eltérést mutató zöngétlen hangok között ( $\mathrm{t}-\mathrm{c}$ és sz-c párok), a képzési módban megegyező zöngétlen hangok között (c-cs), valamint a képzési módjukban és helyükben is különböző zöngétlen hangok között ( $\mathrm{t}-\mathrm{cs}$ ) lép fel akusztikai és ejtésbeli hasonlóság. A likvidák esetében $(1-\mathrm{j})$ a képzési hely és mód is különbözőséget mutat. Szintén a képzés módja szerinti azonosságot tapasztalhatunk a zöngétlen $\mathrm{p}-\mathrm{t}, \mathrm{s}-\mathrm{f}, \mathrm{t}-\mathrm{k}$ és $\mathrm{sz}-\mathrm{f}$, valamint a zöngés $\mathrm{d}-\mathrm{g}$ hangpárok, valamint a képzési módjukban szomszédos $\mathrm{j}-\mathrm{n}$ és $\mathrm{b}-\mathrm{v}$ zár- és réshangok között. Meixner \& Justhné (1967) az egyéb kategóriába sorolja cs-gy és az ny-v hangpárokat. Mindkét hangpár a képzés módja és helye szerint is eltérést mutat, valamint a cs-gy pár első hangja zöngétlen, míg a második zöngés, az ny-v hangpár esetében viszont mindkét hang zöngés. 
5. táblázat. Betütévesztések lehetösége optikai, akusztikai és ejtésbeli hasonlóság alapján (Forrás: Meixner \& Justhné, (1967. p. 32-3.)

\begin{tabular}{|c|c|}
\hline $\begin{array}{l}\text { Optikai hasonlóság alapján } \\
\text { Magánhangzók: }\end{array}$ & Akusztikai és ejtési hasonlóság alapján \\
\hline $\begin{array}{l}\text { Magánhangzók: } \\
\qquad \begin{array}{l}\mathrm{a}-\mathrm{a} \\
\mathrm{e}-\mathrm{e} \\
\\
\ddot{\mathrm{u}}-\mathrm{u} \\
\mathrm{o}-0 ̋\end{array}\end{array}$ & Magánhangzók: \\
\hline \multirow{7}{*}{$\begin{array}{c}\mathrm{t}-\mathrm{f} \\
\mathrm{p}-\mathrm{d} \\
\mathrm{h}-\mathrm{n} \\
\mathrm{b}-\mathrm{d} \\
\mathrm{c}-\mathrm{cs} \\
\mathrm{m}-\mathrm{n} \\
\mathrm{v}-\mathrm{k} \\
\mathrm{g}-\mathrm{gy}\end{array}$} & $\begin{array}{l}\text { Mássalhangzók } \\
\text { zöngés-zöngétlen: }\end{array}$ \\
\hline & $\begin{array}{l}\text { orális és nazális: } \\
\qquad \begin{array}{c}\mathrm{p}-\mathrm{m} \\
\mathrm{t}-\mathrm{n} \\
\mathrm{gy}-\mathrm{ny}\end{array}\end{array}$ \\
\hline & $\begin{array}{ll}\text { lágyított hang: } & \text { gy }-\mathrm{j} \\
& \mathrm{gy}-\mathrm{d} \\
\mathrm{ny}-\mathrm{j}\end{array}$ \\
\hline & $\begin{array}{l}\text { affrikáták: } \\
\qquad \begin{array}{c}\mathrm{sz}-\mathrm{c} \\
\mathrm{t}-\mathrm{c} \\
\mathrm{t}-\mathrm{cs} \\
\mathrm{cs}-\mathrm{s}\end{array}\end{array}$ \\
\hline & likvidák: $\quad \quad r-j$ \\
\hline & $\begin{array}{l}\text { hasonló módon, egymással szomszédos területen } \\
\text { képzett hangok: } \\
\qquad \begin{array}{l}\mathrm{p}-\mathrm{t} \\
\mathrm{s}-\mathrm{f} \\
\mathrm{t}-\mathrm{k} \\
\mathrm{j}-\mathrm{n} \\
\mathrm{sz}-\mathrm{f} \\
\mathrm{b}-\mathrm{v} \\
\mathrm{d}-\mathrm{g}\end{array} \\
\end{array}$ \\
\hline & $\begin{array}{l}\text { egyéb: } \\
\qquad \begin{array}{c}\mathrm{cs}-\mathrm{gy} \\
\mathrm{n}-\mathrm{v}\end{array}\end{array}$ \\
\hline
\end{tabular}

Összességében elmondható, hogy ugyanúgy, mint a fonológiai tudatosság fogalma kapcsán, úgy a fonológiai tudatosság fejlődésénak jellemzése során is eltérő nézetek bontakoznak ki. A nézetek egyetértenek abban, hogy a fonológiai tudatosság fejlődésében két fő szint különböztethető meg, viszont ezek a szintek több esetben, nagymintás, reprezentatív vizsgálat hiányában, csupán egy-egy feltárás, mérés eredményeit tükrözik. A fonológiai tudatosság fejlődését befolyásolhatja az adott nyelv szerkezete, gazdagsága, így fontos tanulmányozni a vizsgálat nyelve során megjelenő olyan általános szempontokat, melyek 
befolyásolhatják a feladatok nehézségét, illetve szem előtt tartani a vizsgálat nyelvének alapvető hangtani jellemzőit.

\subsection{A fonológiai tudatosság és az olvasás kapcsolata}

Számos tanulmány, különböző elméleteket tár fel az olvasási képesség és a fonológiai tudatosság kapcsolatáról. Ezen elméletek egyetértenek abban, hogy a fonológiai tudatosság (Brady, Braze, \& Fowler, 2011; Adrews \& Wang, 2014; Mayer \& Trezek, 2014), és a részképességének tekintett fonématudatosság (Hatcher, Hulme, \& Ellis, 1994; Smith, Scott, Roberts, \& Locke, 2008) kulcsfontosságú szerepet tölt be az olvasástanulás folyamatában, valamint meghatározó mind a dekódolás (Blomert \& Csépe, 2012), mind a szövegértés (Nation \& Snowling, 2004) tekintetében.

Bár a fonológiai tudatosság és olvasási teljesítmény közötti kapcsolathoz nem fér készség, megoszlanak a vélemények a tekintetben, hogy a két változó között reciprok vagy ok-okozati kapcsolat áll fenn. A fonológiai tudatosság és az olvasás kapcsolatában a kutatások háromféle kapcsolatot igazoltak. Egyrészt a fonológiai tudatosság fejlettségi szintje befolyásolja a későbbi olvasásteljesítményt (Hatcher, Hulme, Miles, Carroll, Hatcher, Gibbs, \& Snowling, 2006; Lonigan, Purpa, Wilson, Walker, \& Clancy-Menchetti, 2013), hiszen azok a gyermekek, akik a fonológiai tudatosság részképességeinek elsajátításában nem érik el az optimum szintet, azok később, az olvasni tanulás kezdeti szakaszában nehézségekkel küzdenek. A fonológiai tudatosság az olvasási képesség alakulásában betöltött kulcsszerepét jól tükrözi, hogy a 4-8 éves korosztály számára készült Diagnosztikus Fejlődésvizsgáló Rendszer (DIFER) beszédhanghallás résztesztje is a fonológiai tudatosság egy szeletének vizsgálatára irányul (Nagy, Józsa, Vidákovich, \& Fazekasné, 2004). A területen lemaradással küzdő óvodáskorú gyermekek számára kidolgozott célzott fejlesztőprogramok nagymértékben hozzájárulnak az olvasás későbbi sikerességéhez. Másrészt Morais (1991) a szó felépítésével, szerkezetével kapcsolatos tudás hiányára, csekély mivoltára világít rá az olvasni nem tudó felnőttek, illetve az olvasást a nem alfabetikus írásrendszer alapján tanulók esetében. Ezzel rámutat arra, hogy a fonológiai tudatosság az olvasástanulás hatására fejlődik. Harmadrészt pedig az olvasástanulás hatására kétirányú, egymást támogató fejlődési folyamat tapasztalható (Klicpera \& GasteigerKlicpera, 2005; Castles \& Coltheart, 2004). A kutatások abban megegyeznek, hogy a fonémaazonosítási és differenciálási képesség kiemelkedő prediktora a későbbi olvasási teljesítménynek (Ziegler \& Goswami, 2005). az olvasástanulás korai szakaszában az egyik legmeghatározóbb tényező a fonológiai tudatosság (Cooper, Roth, \& Speece, 2002; Deacon, 
2012; Carson, Gillon, \& Boustead, 2013; Wackerle-Hollman, Schmitt, Bradfield, Rodriguez, \& McConell, 2013), illetve a fonológiai tudatosságon belül kiemelkedik az óvodás korban mért fonématudatosság (Duff, Hulme, Grainger, Hardwick, Miles, \& Snowling, 2012).

A fonológiai tudatosság fejlődésében, valamint az olvasástanulás folyamatában meghatározó tényező a vizsgált nyelv ortográfiája. Ortográfiának az írásrendszerek alaktanát nevezzük, melyekben bár a betü-beszédhang megfeletetések szám korlátozott, de az általuk alkotott kombinációk száma véges lehet (Blomert \& Csépe, 2012; Perfetti \& Maron, 1998). Ziegler \& Goswami (2005) három fő befolyásoló tényezőt emelt ki a fonológiai tudatosság és az olvasás fejlődése kapcsán: (1) a hang-betű és betü-hang megfeleltetést, mely kétirányú kapcsolattal a agyermekek az olvasástanulás kezdeti szakaszában még nem rendelkeznek, azaz nincs explicit tudásuk sem a beszédhangokról, sem a betűkről, (2) a betü-beszédhang, beszédhang-betű konzisztenciát, azaz, hogy egy hanghoz mennyi, mennyiféle betü, betűkombináció rendelhető, a betü-hang kombinációnak hányfajta kiejtése létezik, és a (3) granualitást, azaz a fonológiai rendszerhez illesztett ortográfiai egység méretét (Csépe, 2014; Szili, 2016). Azon nyelvek esetében, melyek sekély ortográfiai rendszerrel rendelkeznek, azaz a szófelismeréshez szükséges elemek kevesebb és/vagy kisebb egységekből állnak, az írásrendszer összetevői és a beszélt nyelvi elemek nagyfokú hasonlóságot mutatnak, hamarabb kialakul a fonématudatossági szint, míg a mély ortográfiájú nyelvek esetében, melyekben az alkalmazott írásrendszer összetevői és a beszélt nyelvi egységek közötti megfeltetés nem egyértelmű, az olvasásfejlődés első szakasza elnyúlik.

Számos kutatás vizsgálja a fonológiai tudatosság és az olvasás reciprok hatását. A kutatások egyik vonulata fonológiai tudatosság fejlesztésének olvasásteljesítményre gyakorolt hatását vizsgálja. Gillon (2002) 5-7 éves, új-zélandi beszédproblémás gyermekek számára fonológiai tudatosságot fejlesztő tréninget biztosított. A fejlesztés hatásának igazolására ugyanilyen jellemzőkkel rendelkező kontrollcsoportot állított fel. A tréningen részt vett gyermekek esetében erősödtek a fonéma-graféma kapcsolatok, valamint a fonológiai tudatossági és a szófelismerési feladatok során szignifikánsan jobb eredményt értek el a kontrollcsoportban szereplő, ez irányú fejlesztésben nem részesült gyermekeknél.

Stackhouse et al. (2002) kutatásai rámutattak arra, hogy a rímfelismerés nem, viszont a fonématudatosság előrejelzi a későbbi gyenge olvasási és helyesírási teljesítményt. Lundberg, Frost, \& Peterson (1988) dán óvodásokkal kezdett longitudinális vizsgálata során a kísérleti csoport napi 15-20 perces tréningen vett részt, míg a kontrollcsoport ebben nem részesült. $\mathrm{Az}$ általános iskola első osztályában mért eredmények alapján a tréningen résztvevő gyermekek helyesírási teljesítményében szignifikánsan jobb teljesítmény mutatkozott, míg az olvasási 
tesztben nem tapasztaltak számottevő különbséget. Második osztályra mind az olvasás, mind a helyesírás területén a tréningben részesülők eredményei szignifikánsan magasabbnak mutatkoztak. Lundberg kutatása továbbá rámutatott arra, hogy a fonémaszintézis, a szókezdő fonéma törlése, valamint a fonémaazonosítás és -differenciálás prediktálja leginkább a későbbi olvasási és helyesírási teljesítményt. Lonigan et al. (2013) 318 iskolakezdés előtt álló (preschooler) gyermekkel végzett kontrollcsoportos vizsgálatában rámutatott arra, hogy a fonológiai tudatosság közvetlen tanításában részesült gyermekek, az ezirányú teszteken, szignifikánsan jobb teljesítmény nyújtottak a hagyományos olvasás és ABC tanulással oktatott társaiknál. Bailet, Repper, Murphy, Piasta, \& Zetter-Greeley (2013) iskolakezdés előtt gyermekek vizsgálata során szintén hasonló következtetésre jutott, munkájuk során kimutatták, hogy a korai intervenció pozitív irányba mozdította el a gyermekek fonológiai tudatosságának fejlődését.

Fontos megjegyezni, hogy a fonológiai tudatosság fejlettsége nem az egyetlen olyan szempont, mely a későbbi olvasási teljesítmény befolyásolhatja. Furnes \& Samuelsson (2010) tanulmánya alapján megállapítható, hogy az olvasási nehézségekkel küzdő gyermekek szintén nehézséget mutathatnak nemcsak a fonológiai tudatosság (Rack, Snowling, \& Olson, 1992; Stanovich \& Siegel, 1994), hanem a betüismeret (Pennington \& Lefly, 2001; Snowling, Gallagher, \& Frith, 2003), a gyors automatikus megnevezés (Wolf \& Bowers, 1999), a verbális memória (Swanson \& Siegel, 2001), és a szemantikai és szintaktikai képességek terén (Catts, Fey, Zhang, \& Tomblin, 1999; Rego \& Bryant, 1993) is.

Jelen fejezet elméleti áttekintéséből látható, hogy bár a fonológiai tudatosság meghatározása sokrétü, a fejlődésének üteme, valamint egyes részképességek kialakulása nyelvterületeként eltérő lehet, mégis az olvasás egyik olyan meghatározó kognitív faktorának sokrétủ szerepe jelenik meg, melynek megfelelő fejlettsége nélkül az írás-olvasástanulás és tanítás folyamata akadályokba ütközhet. Ez okból kifolyólag indokolttá válik a képesség fejlődésének kisgyermekkori monitorozása, mely a későbbi fejlesztések alapjául szolgálhat. 


\section{A FONOLÓGIAI TUDATOSSÁG MÉRÉSEI LEHETŐSÉGEI - A HAZAI ÉS NEMZETKÖZI MÉRÉSI TENDENCIÁK ÁTTEKINTÉSE}

A fonológiai tudatosság vizsgálata az 1970-es évektől egyre inkább előtérbe került (Bradley \& Bryant, 1983; Gillon, 2017; Leong \& Sheh, 1982; Marcel, 1980; Rozin \& Gleitman, 1977; Tunmer\& Fletcher, 1981; Zifcak, 1981). A vizsgálati, mérési tendenciák hazai és nemzetközi szinten is változatos képet mutatnak. A gyermekek, tanulók teljesítményének vizsgálatára norma-, és kritériumorientált tesztek, a 21. század lehetőségeit kihasználva pedig már nemcsak szemtől-szembeni, hanem számítógép segítette, illetve online mérési módszerek is megjelennek.

A fonológiai tudatosságon belül megjelenő fonématudatosság már az óvodás korú gyermekek körében is mérhető (Farrall, 2012). Az első fonématudatosságot mérő teszt Bruce nevéhez köthető (Bruce, 1964). Bruce, nagyságrendileg 10 perces tesztje során fonématörlési feladatok szerepelnek, a vizsgált személynek szóban kell válaszolnia a kérdésre, hogy milyen új szót kap egy meghatározott, specifikus hang leválasztása után. Napjainkban a fonológiai tudatosság vizsgálata már számítógép-alapú mérések során is megjelenhet (Wagner, Torgesen, Rashotte, \& Pearson, 2013). Hazánkban a legelterjedtebb, szemtől szembeni, a fonológiai tudatosság fonémaszintủ azonosítási és differenciálási müveleteit magában foglaló mérőeszköz a Difer beszédhanghallás résztesztje (Nagy et al., 2004). A technológiaalapú mérésben rejlő lehetőségeket kihasználva az utóbbi években elkészült a Difer teszt online verziója (Csapó, Molnár, \& Nagy, 2014), valamint további kutatások is megjelentek a beszédpercepció, valamint a fonológiai tudatosság és a mentális lexikon fejlettségének vizsgálatára (Szili \& Pásztor, 2013). Ezen mérések a kisiskolás tanulókra irányultak, hiányterületnek számít az óvodás korosztály ezirányú vizsgálata.

\section{1. A nemzetközi mérési tendenciák}

A nemzetközi mérési tendenciák áttekintése során angol nyelvü tesztek szerepelnek. Rathvon (2004) a mérőeszközöket a vizsgált komponensek alapján kategorizálja, elkülönítve a korai olvasási képesség komponenseire alapuló méréseket (fonológiai feldolgozás, gyors automatikus megnevezés, ortográfiai feldolgozás, a beszélt nyelv, a nyomtatott szöveg ismerete, betűismeret, szóolvasás, hangos olvasás, szövegértés, írott nyelv), valamint az olvasás komponenseit vizsgáló bettériákat. Rathvon a fonológiai tudatosság mérését három kritikus problémakör mentén vizsgálja: (1) a feladatok sztenderdizálásának hiánya, (2) a feladatok prediktív validitásának relatív volta az olvasásfejlődés különböző szakaszaiban, valamint (3) a 
vizsgáztató és pontozó variancia. A fonológiai tudatosság résztesztjei, tesztfeladatai rendkívül sokszínűek (6. és 7. táblázat). A feladatok, feladattípusok felvételének sorrendje nem minden esetben meghatározott, a feladatok kontextusa, valamint nehézségi szintje, összetettsége, a mérőbiztos személye és a válaszadás módja eltérést mutathat. A feladatok előrejelző ereje nem tisztázott, nyelvenként, de akár mérőeszközönként is eltérést mutathat. Az említett táblázatokban található mérőeszközök a fonológiai tudatosság legalább egy részterületét vizsgálják, és az óvodás korú gyermekek, illetve általános iskola első osztályos tanulók számára kidolgozott feladatokat tartalmazzák. A mérőeszközök részben Rathvon (2004), részben pedig saját gyüjtés alapján kerültek beemelésre. A méröeszközöket a tesztbattéria jellemzői alapján csoportosítottuk. Bár mindkét battériatípus tartalmaz olyan elemeket, melyek a fonológiai tudatosság mérését biztosítják, a feladatok kontextusa eltérő. Az első csoport olyan mérőeszközöket tartalmaz, melyek a korai olvasási képesség komponenseit vizsgálják. A bemutatott mérőeszközök esetében a fonológiai tudatosság egy-egy részterületének vizsgálata mellett megjelenik a betü-beszédhang megfeleltetés, az álszóolvasás, a hangosolvasás, a hallás utáni értés és írás, a betüzés, a szófelismerés, az ortográfiai, szemantikai és szintaktikai feldolgozás, valamint az olvasási fluencia is. A bemutatott mérőeszközök széles életkori szakaszt fednek le, de természetesen korosztályspecifikus vagy épp opcionális,elhagyható feladatokat is tartalmaznak (6. táblázat).

A korai olvasási képesség komponenseinek mérőeszközei közül először a Dynamic Indicators of Basic Early Literacy Skills (2002) tesztet mutatjuk be. A mérőeszköz számos változata ismert, jelenleg a hatodik kiadása $\left(\operatorname{DIBELS}^{6 \text { th }}\right)$ használatos (Good \& Kaminski, 2002). A DIBELS $^{6 \text { th }}$ a fonématudatosság mellett olvasási fluenciát is mér. Mivel a teszt széles életkori sávot lefed (óvodától hatodik osztályig), ezért a mérőeszközben, főként a vizsgált személyek olvasási képességeihez igazodva jelennek meg a rögzítendő résztesztek, melyek közül az egyes mérési alkalmak esetében szerepelnek kötelezően felveendő és opcionális egységek is (Cummings, Otterstedt, Kennedy, Baker, \& Kame'euni, 2011). A DIBELS ${ }^{6 \text { th }}$ formatív értékelést biztosít, míg a következő, továbbfejlesztett változata a DIBELS Next, már kritériumorientált értékelési formában gondolkodik. A DIBELS ${ }^{6 \text { th }}$ a 10 hónapos nevelési évet/ tanévet három hónapos ciklusokra bontja, a gyermekek, tanulók vizsgálata a nevelési év/tanév elején, közepén és végén valósul meg.

A Fox in a Box (Adams, Treadway, \& CTB/McGraw-Hill, 2000) teszt által vizsgált részterületek négy nagyobb egység, a fonématudatosság, a fonéma-graféma megfeleltetés, az olvasás és szóbeli kifejezésmód és a hallás utáni értés és írás köré szerveződnek. Jellemzően a fonématudatosság köré csoportosuló feladatokat (rímprodukció, szótagtapsolás, szegmentálás, 
szintézis, szókezdő és szóvégi mássalhangzók felismerése) csak az óvodáskorban vizsgálják. A teszt kritériumorientált értékelési rendszerrel dolgozik, mely óvodától második évfolyamig alkalmazható. A mérések időtartama 100-122 perc között alakul. A teszt rögzítésére évente kétszer kerül sor, a kora őszi méréseket általában egy tavaszi kontrollmérés követi. A teszt gyermekközpontúságát bizonyítja, hogy a kisebbek számára a feladatokat egy róka báb segítségével teszik érdekesebbé, fenntartva ezzel a gyermekek érdeklődését és motivációját.

A Group Reading Assessment and Diagnostic Evaluation (Williams, 2002) teszt 16 részterületen keresztül vizsgál öt olvasási előkészséget és olvasási komponenst az óvoda kezdő szakaszától egészen felnőttkorig. A legkisebb korosztály esetében a teszt a képazonosítási feladatok mellett csupán szókezdő és szóvégi hangok azonosítását kérő, valamint rímkeresési feladatokat alkalmaz, míg az idősebb korosztály esetében megjelennek szókincset, szövegértést vizsgáló résztesztek. A mérőeszköz standardizált. A teszt felvételének ideje 45 és 115 perc közé tehető, mely nagymértékben függ a vizsgált minta életkorától, a gyermekek/tanulók olvasási képességének fejlettségétől, és az említett két tényezőből következően, a bevonható résztesztek számától is.

Phonological Awareness Literacy Screening (Invernizzi \& Meier, 2002a, 2002b) a fonológiai tudatosság egyes elemein túl a fonéma-graféma megfeltetést, a betüzést és a szófelismerés képességét is vizsgálja. A mérőeszköz kritériumorintált értékelési formával dolgozik, főként nagymintás, longitudinális adatfelvétel esetén alkalmazzák. A tesztet óvodától egészen harmadik osztályig évente két alkalommal, ősszel és tavasszal rögzítik. A mérőeszköz célja kettős: egyrészt azon gyermekeket/tanulókat kívánja feltérképezi, akik olvasási képességükben elmaradást mutatnak, másrészt gyermekek/tanulók olvasási előképességeire vonatkozó azon változókat kívánja feltárni, melyek támogatják a további oktatási folyamat megtervezését.

Phonological Awareness Screening Test (Adams, Foorman, Lundberg, \& Beeler, 1998) a szótag- és fonématudatosság, betü-beszédhang megfeletetést, valamint a szavak hosszúságának össszehasonlítását vizsgálja óvodától első évfolyamig. A mérőeszköz nem standardizált, melyet eredetileg Dániában és Svédországban fejlesztettek ki. A normaorientált mérőeszköz a gyermekek/tanulók teszten nyújtott teljesítményének jellemzésére, a gyermekek képességeinek egymáshoz való viszonyítására alkalmas. A teszt rögzítése történhet egyéni és csoportos tesztfelvétel során. A résztesztenként 5 itemet tartalmazó mérőeszköz szemtől szembeni rögzítése nagyságrendileg 30 percet vesz igénybe.

Predictive Reading Profile (Flynn, 2001) az olvasás előkészségeinek vizsgálatát négy fö szempont, a fonológiai, ortográfiai, szemantikai és szintaktikai feldolgozás körül vizsgálja. A 
mérőeszköz hat kötelezően rögzítendő, illetve opcionális részteszteket is tartalmaz mint a történetírás, szegmentálás, törlés és tanári értékelő skála. A teszt rögzíthető egyéni tesztelés során, de alkalmazható kiscsoportos, valamint osztálytermi környezetben is.

A Texas Primary Reading Inventory (Foormann, Fletcher, Francis, Carlson, Chen, \& Mouzaki, 2002) az olvasási előképességek mérésére fejlesztett mérőeszköz, mely öt olvasási komponenst (a fonématudatosságot, a betü-beszédhang megfeletetést, az olvasási pontosságot, a szövegértést és az olvasási fluenvciát) vizsgál. A teszt standardizált, óvodától egészen második évfolyamig alkalmazható, rögzítésére az óvodai korcsoportban évente kétszer, a nevelési év közepén és végén, az általános iskolai tanulók körében pedig az első és második osztály elején kerül sor. Opcionális mérési pontként szerepel az általános iskolai tanulók esetében egy második adatfelvétel, mely a tanév közepén jelenik meg.A mérőeszközt Texas iskoláinak több mint 95\%-ában alklamazzák.

\section{6. táblázat. A korai olvasási képesség komponenseire irányuló mérések}

\begin{tabular}{|c|c|c|}
\hline A mérőeszköz megnevezése & A vizsgált területek, szubtesztek & Korosztály \\
\hline $\begin{array}{l}\text { Dynamic Indicators of Basic Early } \\
\text { Literacy Skills 6th Edition (2002) }\end{array}$ & $\begin{array}{l}\text { szókezdő hang azonosítása } \\
\text { betü-hang megfeleltetés } \\
\text { álszóolvasás } \\
\text { hangos olvasás }\end{array}$ & óvodától 6. évfolyamig \\
\hline Fox in a Box (2000) & $\begin{array}{l}\text { fonématudatosság } \\
\text { fonéma-graféma megfeleltetés } \\
\text { olvasás és szóbeli kifejezésmód } \\
\text { hallás utáni értés és írás }\end{array}$ & óvodától 2. évfolyamig \\
\hline $\begin{array}{l}\text { Group Reading Assessment and } \\
\text { Diagnostic Evaluation (2002) }\end{array}$ & $\begin{array}{l}\text { rímfelismerés képek alapján } \\
\text { szókezdő és szóvégi hangok } \\
\text { azonosítása } \\
\text { nyomatott szöveg ismerete } \\
\text { szókincs } \\
\text { szövegértés } \\
\text { fonéma-graféma megfeleltetés }\end{array}$ & $\begin{array}{l}4 \text { éves kortól } \\
\text { felnőttkorig }\end{array}$ \\
\hline $\begin{array}{l}\text { Phonological Awareness Literacy } \\
\text { Screening (2002) }\end{array}$ & $\begin{array}{l}\text { rímelö képek, azonos hanggal } \\
\text { kezdődő képek párosítása } \\
\text { hangok keverése } \\
\text { szókezdő, szóbelseji és szóvégi } \\
\text { hangok azonosítása, megnevezése } \\
\text { fonémaszintézis } \\
\text { betü-beszédhang megfeleltetés } \\
\text { betűzés } \\
\text { szófelismerés }\end{array}$ & óvodától 3. évfolyamig \\
\hline $\begin{array}{l}\text { Phonological Awareness Screening } \\
\text { Test (1998) }\end{array}$ & $\begin{array}{l}\text { rímkeresés } \\
\text { szótagszámlálás } \\
\text { szókezdő hangok azonosítása } \\
\text { fonémaszámlálás }\end{array}$ & óvodától 1. évfolyamig \\
\hline
\end{tabular}




\begin{tabular}{|c|c|c|}
\hline & $\begin{array}{l}\text { szavak hosszának } \\
\text { összehasonlítása (fonémák } \\
\text { alapján) } \\
\text { betú-beszédhang megfeleltetés } \\
\text { szókezdő hangok alapján }\end{array}$ & \\
\hline Predictive Reading Profile (2001) & $\begin{array}{l}\text { fonológiai feldolgozás } \\
\text { (fonémaazonosítás, szótag és } \\
\text { fonéma számlálás, } \\
\text { fonémaszegmentálás) } \\
\text { ortográfiai feldolgozás } \\
\text { szemantikai feldolgozás } \\
\text { szintaktikai feldolgozás }\end{array}$ & 5-6 éves korosztály \\
\hline $\begin{array}{l}\text { Texas Primary Reading Inventory } \\
(2002)\end{array}$ & $\begin{array}{l}\text { fonématudatosság (szókezdő és } \\
\text { véghangok törlése, szintézis) } \\
\text { betú-beszédhang megfeleltetés } \\
\text { olvasási pontosság } \\
\text { szövegértés } \\
\text { olvasási fluencia }\end{array}$ & óvodától 2. évfolyamig \\
\hline
\end{tabular}

A mérőeszközök másik csoportja az olvasás komponenseire alapuló méréseket tartalmaznak. A fonológiai tudatosság feladatai mellett megjelennek a gyors automatikus megnevezéshez, a dekódoláshoz, kézíráshoz, helyesíráshoz köthető feladatok is. Egyes áttekintett mérőeszközök a feladatok sokszínűsége és összetettsége miatt óvodától egészen felnőttkorig alkalmazhatók (7. táblázat).

A Comprehensive Test of Phonological Processing (CTOPP, Wagner, Torgesen, \& Rashott, 1999), valamint annak 14 évvel későbbi újbóli kiadása (CTOPP-2, Wagner, Torgesen, Rashott, \& Pearson, 2013) a fonológiai tudatosság fő mentális müveletein túl az olvasás egyéb kognitív faktorát, a gyors automatikus megnevezést is vizsgálja. A teszt első kiadása az 5-6, valamint a 7-24 éves korosztály vizsgálatára alkalmas, míg a második kiadás már 4-6 éves korosztályt vizsgál. A két életkori szakasz szétválasztásának oka a feladatok nehézségi szintjében rejlik, hiszen míg a fonológiai tudatosságra épülő feladatok a 4-5-6 évesek is megfelelőnek bizonyultak, addig az olvasással, dekódolással járó feladatok ezen korosztály számára nem teljesíthetők. A teszt bár szemtől szembeni felvételen alapszik, CD melléklettel rendelkezik. A vizsgált személyek teljesítményét minden esetben a mérőbiztos rögzíti.

A Dyslexia Screening Test (Nicolson \& Fawcett, 1996) 11 részterületet tartalmaz. Ezek között már található szóolvasást, betüzést, verbális (megadott kezdőhang alapján) és szemantikai (megadott téma alapján) fluenciát, valamint munkamemóriát terhelő számsorismétlés visszafelé típusú feladat is. A 6-16 éves gyermekek, tanulók teljesítményét százalékos eredményeik alapján öt kategóriába sorolják. Főként a fiatalabb korosztály esetében javasolt a félévenkénti tesztfelvétel. Bár a mérőeszköz rögzítése szemtől szembeni 
adatfelvételen alapszik, egyes feladatok felvételét audiokazettára rögzített hanganyaggal segítették.

A Phonological Abilities Test (Muter, Hulme, \& Snowling, 1997) A teszt olyan részképességek vizsgálatát célozta meg (7. táblázat), melyek a későbbi olvasási teljesítmény prediktorai. A mérőeszköz normaorientált értékelést biztosít a 4-7 éves gyermekek számára. A teszttel végzett vizsgálatok fő eredményének tekinthető azon következtetés, mely szerint a különböző életkorú gyermekek esetében, más-más részterületeken elért teljesítmény határozza meg a későbbi olvasási teljesítményt. Az ötévesek esetében a rímfelismerés, a szókezdő és szóvégi fonémák törlése és a betüismeret, a hatévesek esetében a rímprodukció, a szókezdő és szóvégi fonémák törlése és a betüismeret, a hétévesek esetében pedig a rímfelismerés, a fonémák törlése a két, már említett pozícióban, a betűismeret és a produkció sebessége meghatározó. Összességében elmondható, hogy a minden életkori csoportban meghatározó, szókezdő és szóvégi fonématörlés mutatta a legerősebb kapcsolatot a későbbi olvasásteljesítménnyel.

Phonological Awareness Test (Robertson \& Salter, 1997), valamint második kiadása, a Phonological Awareness Test $-2^{\text {nd }}$ edition (Robertson \& Salter, 2007a) a fonológiai tudatosság, valamint a betü-beszédhang megfeleltetés és a dekódolás fejlettségi szintjének kimutatására alkalmazható 5-11 éves gyermekek körében. A résztesztek között szerepelnek opcionálisan rögzítendők is, hiszen a mérőeszközzel végzett vizsgálatok széles életkori csoportot fednek le, így a feladatok nehézségi szintje, illetve a feladatok megoldásához szükséges háttértudás mértéke eltérő. A teszt szemtől szembeni felvételen alapszik, viszont egyes részei (a dekódolás és a graféma szubteszt) már elöre rögzített hanganyag, illetve színes kockák és vonalas lap segítségével kerül rögzítésre. A teljes teszt rögzítése nagyságrendileg 40 percet vesz igénybe. A teszthez elérhető egy felhasználóbarát értékelő, pontozó szoftver is. A teszt második kiadásának - Phonological Awareness Test $-2^{\text {nd }}$ edition (Robertson \& Salter, 2007a) rögzítése nagyságrendileg szintén 40 percet igényel, viszont a második kiadás mérési útmutatója kitér arra, hogy a teszt több ülésben, több mérési alkalomra lebontva is rögzíthető. A feladatok rögzítéséhez kizárólag olyan mérőbiztosokat alkalmaznak, akik előzetes képzettséggel rendelkeznek a nyelv fonológiai struktúrájára vonatkozóan, tehát főként beszédterapeutákkal, gyógypedagógusokkal vagy olvasást tanító pedagógusokkal dolgoznak (Robertson \& Salter, 2007b).

Process Assessment of the Learner: Test Battery for Reading and Writing (Berninger, 2001) tesztben a fonológiai tudatosságot vizsgáló szubtesztek közül óvodáskorban szótag és rím szintű feladatok szerepelnek, első évfolyamon szótag és fonéma, míg második évfolyamra 
már csak fonéma szintű feladatokat találhatunk, illetve második évfolyamban egy új, a betűzést kérő feladattípus is megjelenik. A mérőeszköz óvodától hatodik évfolyamig alkalmazható, normaorientált teszt. A mérőeszköz célja a gyermekek/tanulók képességeinek monitorozása, az esetlegesen fellépő problémák diagnosztizálása, illetve azon gyermekek/tanulók feltérképezése, akik elmaradással küzdenek az olvasás és/vagy íráskészségek terén. A tesztcsomag különböző manuális kiegészítőket tartalmaz (pl. fa toll), melynek célja egyrészt a feladatok szemléltetése, másrészt a tanulók válaszadási módjának könnyítése. Mivel a mérőeszköz tág életkori szakaszt vizsgál, illetve a szubtesztek a különböző életkori csoportok fejlettségéhez igazodnak, ezért az életkor előrehaladtával - föként az olvasástanulás -anítás hatására, óvoda és második évfolyam között - a mérőeszköz struktúrája átalakul.

A Test of Language Development - Primary: Third Edition (Newcomer \& Hammill, 1997) bár számos területet vizsgál, a fonológiai tudatosság feladatok kis számban képviseltetik magukat. A feladatok között csupán a két nyelvi szintet (szótag és fonéma) magában foglaló törlési feladatok jelennek meg. A teszten nyújtott eredmények alapján ezek a feladatok az alacsonyabb életkori csoportokban nehéznek bizonyultak, illetve ez az egy feladattípus nem elegendő a gyermekek fonológiai tudatosságának jellemzésére.

A Test of Phonological Awareness (Torgesen \& Bryant, 1994) a szókezdő és szóvégi hangok leválasztására és összehasonlítására fókuszáló teszt, mely óvodától második évfolyamig alkalmazható. A teszt a gyermekek fejlettségi szintjét, életkori sajátosságait figyelembe véve két változattal rendelkezik. Az óvodás korosztály (5-6 évesek) számára kidolgozott változat szókezdő hangokkal operál, míg az általános iskolások (6-8 évesek) számára készítettek esetében szóvégi hangok jelennek meg. Mind a két változat vizuális segédeszköz, azaz képek alapján keresi az azonosságot és különbséget a szókezdő és/vagy szóvégi hangok esetében. A méröeszköz egyéni képességmérésre is alkalmas, valamint kiscsoportos (kb. hat gyermek/tanuló) és osztálytermi környezetben is rögzíthető. A teszt rögzítéséhez két mérőbiztos szükséges, közülük az egyik a klasszikus mérőbiztosi feladatot látja el, tehát a feladatok közlésére fókuszál, míg a másik mérőbiztos arra figyel, hogy a gyermekek/tanulók valóban az utasításokat követik-e, illetve önállóan dolgoznak-e. A teszt rögzítése megközelítőleg 15-30 percet vesz igénybe, mely függ attól is, hogy egyszerre hány gyermekkel dolgoznak a mérőbiztosok.

Yopp-Singer Test of Phoneme Segmentation (Yopp, 1995) a gyermekek fonéma elkülönítésének, izolálásának és produkciójának nem standardizált mérőeszköze. A teszt elsősorban az óvodai korosztályt célozza meg, de általános iskola első osztályában is alkalmazható, tanév elején, egyfajta bemeneti tesztként. Ebben az esetben a mérőeszköz 
segítséget nyújt azon gyermekek/tanulók feltérképezéséhez, akik a fonológiai tudatosság terén elmaradással rendelkeznek.

\section{7. táblázat. Az olvasás komponenseire alapuló mérőeszközök}

\begin{tabular}{|c|c|c|}
\hline A mérőeszköz megnevezése & Vizsgált területek, szubtesztek & Korosztály \\
\hline $\begin{array}{l}\text { Comprehensive Test of } \\
\text { Phonological Processing (1999) és } \\
\text { Comprehensive Test of } \\
\text { Phonological Processing } 2 \text { (2013) }\end{array}$ & $\begin{array}{l}\text { hangelhagyás } \\
\text { hangszintézis szavak és álszavaknál } \\
\text { fonémaazonosítás } \\
\text { hangszegmentálás szavak és álszavaknál } \\
\text { beszédhang-manipulálás } \\
\text { fonológiai memória } \\
\text { gyors automatikus megnevezés }\end{array}$ & $\begin{array}{l}\text { 4-5-6 éves és 7- } \\
24 \text { éves } \\
\text { korosztály } \\
\text { számára }\end{array}$ \\
\hline Dyslexia Screening Test (1996) & $\begin{array}{l}\text { gyors automatikus megnevezés } \\
\text { fonémaszegmentálás } \\
\text { betüzés } \\
\text { szóolvasás } \\
\text { számsorok visszafelé történő ismétlése } \\
\text { verbális és szemantikai fluencia }\end{array}$ & $\begin{array}{l}\text { 6-16 éves } \\
\text { korosztály } \\
\text { számára }\end{array}$ \\
\hline
\end{tabular}

$\begin{array}{lll} & \text { rímfelismerés képek alapján } & \\ & \text { rímképzés } & \\ & \text { kezdő és véghangok törlése } & 4-7 \text { éves } \\ \text { Phonological Abilities Test (1997) } & \begin{array}{l}\text { szavak hangokkal történő kiegészítése } \\ \text { beszédprodukció sebességének vizsgálata }\end{array} & \\ & \text { ugyanazon szó tízszeri ismétlése által } \\ \text { betüismeret }\end{array}$

\begin{tabular}{|c|c|c|}
\hline $\begin{array}{l}\text { Phonological Awareness Test } \\
\text { (1997) }\end{array}$ & $\begin{array}{l}\text { rímfelismerés és -képzés } \\
\text { mondat, szótag és fonéma szegmentáció } \\
\text { hangok izolációja } \\
\text { fonémaszintézis } \\
\text { fonématörlés } \\
\text { fonémahelyettesítés } \\
\text { dekódolás } \\
\text { szavak kiejtése }\end{array}$ & $\begin{array}{l}5-11 \text { éves } \\
\text { korosztály }\end{array}$ \\
\hline $\begin{array}{l}\text { Phonological Awareness Test }-2^{\text {nd }} \\
\text { edition }(2007)\end{array}$ & $\begin{array}{l}\text { rímmel kapcsolatos mủveletek } \\
\text { mondat-, szó-, és hangszegmentálás } \\
\text { hangizolálás } \\
\text { szó-, szótag-, és hangtörlés } \\
\text { hangmanipuláció } \\
\text { hang- és szótagszintézis } \\
\text { betü-hang megfeleltetés }\end{array}$ & $\begin{array}{l}5-9 \text { éves } \\
\text { korosztály }\end{array}$ \\
\hline $\begin{array}{l}\text { Process Assessment of the } \\
\text { Learner: Test Battery for Reading } \\
\text { and writing (2001) }\end{array}$ & $\begin{array}{l}\text { gyors automatikus megnevezés } \\
\text { helyesírás } \\
\text { fonológiai tudatosság (rím, szótag és } \\
\text { fonéma szinten, szótag- és hangtörlési } \\
\text { feladatokkal) }\end{array}$ & $\begin{array}{l}\text { óvodától } 6 . \\
\text { évfolyamig }\end{array}$ \\
\hline
\end{tabular}




\begin{tabular}{|c|c|c|}
\hline & $\begin{array}{l}\text { dekódolás } \\
\text { finommotorika } \\
\text { kézírás (írás-mozgás koordináció) } \\
\text { megértés }\end{array}$ & \\
\hline $\begin{array}{l}\text { Test of Language Development - } \\
\text { Primary: Third Edition (1997) }\end{array}$ & $\begin{array}{l}\text { szemantika } \\
\text { szintaktika } \\
\text { fonológiai tudatosság } \\
\text { hallásutáni értés } \\
\text { rendszerezés } \\
\text { fonéma- és szótagtörlés, } \\
\text { két elhangzott szóról azonosságának } \\
\text { vagy különbözőségének megállapítása }\end{array}$ & $\begin{array}{l}4-8 \text { éves } \\
\text { korosztály }\end{array}$ \\
\hline $\begin{array}{l}\text { Test of Phonological Awareness } \\
\text { (1994) }\end{array}$ & hang-összehasonlítás & $\begin{array}{l}\text { Óvodától } 2 . \\
\text { évfolyamig }\end{array}$ \\
\hline $\begin{array}{l}\text { Yopp-Singer Test of Phoneme } \\
\text { Segmentation (1995) }\end{array}$ & fonémaszegmentálás & óvoda \\
\hline
\end{tabular}

\section{2. A hazai mérési tendenciák}

Hazánkban a fonológiai tudatosság vizsgálatára főként szemtől-szembeni, előszavas felvételen alapuló tesztfeladatok jellemzők, de a nemzetközi tendenciához hasonlóan, már megjelennek az elöre rögzített hanganyaggal (példaanyaggal) rendelkező feladatok, illetve egyes, a feladatok megoldását és a szemléltetést segítő manuális segédeszközök is. A hazai tesztek között szerepelnek magyar nyelvre fejlesztett és adaptált mérőeszközök is.

A GMP-teszt (Beszédészlelési és megértési teljesítmény vizsgálata; Gósy, 1995/2006) az egyik leggyakrabban alkalmazott feladatsor, melynek célja a nyelvi képességek monitorozása. A mérőeszköz a beszédészlelés, beszédmegértés, íráskészség, és olvasásértés területeit 20 alteszten keresztül vizsgálja. A teszt előnye, hogy a GMP-1 részteszt a G-O-H hallásvizsgálatot foglalja magában, mely segítséget nyújt az esetleges hallási deficit kiszűrésére, a globális észlelés feltérképezésére. A beszédhangok megkülönböztetését a GMP-17-es alteszt vizsgálja. A teszt további előnye, hogy az egyes területek elmaradottsága esetén a pedagógus már előre kidolgozott terápiás tervet alkalmazhat. A teszttel kizárólag a GMP diagnosztika tanfolyamot végzett pedagógusok dolgozhatnak, illetve az a mérést követő fejlesztést is kizárólag ők végezhetik.

A DIFER (DIagnosztikus FEjlődésvizsgáló Rendszer) (Nagy, Józsa, Vidákovich, \& Fazekasné, 2004) a sikeres iskolakezdést meghatározó elemi alapkészségek fejlettségét 
vizsgálja 4-8 éves gyermekek körében. A teszt kritériumorientált értékelési rendszerrel rendelkezik, hét készséget, szemtől szembeni vizsgálatok során mér (8. táblázat), de egyes résztesztek feladatlappal (pl. írás-mozgás koordináció) vagy manuális segédeszközzel (az elemi számolási képesség pálcikákkal végzett feladatai) operálnak. A teszt a beszédhanghallás részteszten keresztül vizsgálja a fonológiai tudatosságot, oppozíciós szópárokat alkalmaz, vizsgálja a hangdifferenciálást a szó elején, végén és belsejében (Fazekasné, 2000). A teszt online adaptációjával végzett vizsgálatok (Csapó, Molnár \& Nagy, 2015) általános iskola első osztályos tanulók körében valósultak meg. Az online változat a teljes beszédhanghallás, relációszókincs teszt mind a négy változatát, az elemis zámolási készség műveletek pálcikákkal és számképolvasás részeit, a tapasztalati következtetés és a tapasztalati összefüggés-megértés szubteszteket tartalmazta.

SZÓL-E? - Szürőeljárás az óvodai logopédiai ellátásban (Kas, Lőrik, M. Bogáth, Sz. Vékony, \& Sz. Mályi, 2012), az ötödik életévüket betöltött gyermekek képességeit tíz terület bevonásával vizsgálja A teszt felvétele szemtől szembeni, egyéni tesztelésen alapul, nagyságrendileg 20 percet vesz igénybe. A szürést végző mérőbiztos személye logopédiai végzettséghez kötött. A gyermekek teszten elért eredményeit a logopédus egy 740 fös referenciacsoport eredményeihez viszonyíthatja.

Hangtani Tudatosság teszt (Lőrik \& Májercsik, 2015) 40 itemből álló tesztegyüttes, mely minden részterületet (8. táblázat) 4 itemmel vizsgál, főként fonémaszintre fókuszálva. A tíz vizsgált részterület közül csupán kettő (rímfelismerés és -választás) foglalkozik a fonémánál nagyobb nyelvi egységgel. A teszt az óvoda befejező évében járó gyermekeknek, valamint általános iskola első osztályos tanulói számára készült.

Az amerikai NILD Phonological Awareness Skills Survey (Barbour, Kaefer, \& Scott, 2003) magyar adaptációját és az ahhoz füződő, 22 gyermeket felölelő vizsgálat Jordanidisz (2009) nevéhez füződik. Jordanidisz longitudinális vizsgálatot végzett első, majd ugyanazon második osztályos gyermekekkel. A teszteket egyénileg, 15-20 perc alatt rögzítette, továbbá a gyermekek helytelen válaszait is lejegyezte.

A 3DM-H (Tóth, Csépe, Anniek, \& Blomert, 2014).; Tóth, 2012) a holland 3DM holland teszt (Diszlexia DifferenciálDiagnózisa, Maastricht) magyar adaptációja. Az eredeti mérőeszköz a diszlexia feltárásának hivatalos segédeszköze, a mérőeszköz csupán egyetlen aspestusa vizsgálja a fonológiai tudatosságot, és azon belül is kizárólag egyszótagú szavak fonématörlési feladatiaira fókuszál. A teszt 1-4, évfolyamon standardizált, felnőttek esetében is kpróbálásra került. A méréseket kizárólag képzett pszichológua, logopédus vagy fejlesztőpedagógus végezheti. Az eredményeket egy úgynevezett $\mathrm{KOH}$ (kognitív olvasási, 
helyesírási) indexen keresztül értelmezhetjük. A mutató normapontszámként értelmezendő. A teszt képzéshez és vagy megvásárláshoz kötött.

8. táblázat. A fonológiai tudatosság magyar nyelvü mérőeljárásai

\begin{tabular}{|c|c|c|}
\hline A mérőeszköz megnevezése & A mért részterületek, tesztfeladatok & Korosztály \\
\hline GMP-teszt (2000) & $\begin{array}{l}\text { beszédészlelés (akusztika, fonetika, } \\
\text { fonológia) } \\
\text { beszédértés (szemantikai és szintaktikai } \\
\text { viszonyok) } \\
\text { íráskészség } \\
\text { olvasáskészség }\end{array}$ & 3-6 éves korosztály \\
\hline $\begin{array}{l}\text { DIFER (2004) } \\
\text { (DIFER online változata } \\
\text { (Csapó, Molnár \& Nagy, } \\
\text { 2015)) }\end{array}$ & $\begin{array}{l}\text { írás-mozgás koordináció } \\
\text { beszédhanghallás } \\
\text { relációszókincs } \\
\text { elemi számolási készség } \\
\text { tapasztalati következtetés } \\
\text { tapasztalati összefüggés-megértés } \\
\text { szocialitás }\end{array}$ & 4-8 éves korosztály \\
\hline SZÓL-E? (2012) & $\begin{array}{l}\text { hangképzés (fonetikai, fonológiai } \\
\text { fejlettség, fonológiai feldolgozás és } \\
\text { döntés) } \\
\text { nyelvi fejlettség (verbális munkamemória, } \\
\text { téri viszonyok, tartalmi-szerkezeti } \\
\text { feldolgozás és reprodukció) } \\
\text { olvasás és írástanulás előkészségei } \\
\text { (vizuális felismerés és differenciálás, } \\
\text { fonológiai feldolgozás és reprodukció, } \\
\text { fonológiai tudatosság, lehívás mentális } \\
\text { lexikonból) }\end{array}$ & $\begin{array}{l}\text { óvodáskor, } 5 \text { éves } \\
\text { kortól }\end{array}$ \\
\hline $\begin{array}{l}\text { Hangtani Tudatosság teszt } \\
(2015)\end{array}$ & $\begin{array}{l}\text { rímfelismerés és -választás, szóvégi és } \\
\text { szókezdő szótag leválasztása, szókezdő } \\
\text { hang azonosítása és leválasztása, fonéma } \\
\text { szintézis, szegmentálás és izolálás, } \\
\text { szóvégi hang megadása }\end{array}$ & $\begin{array}{l}\text { óvoda nagycsoport és } \\
\text { első osztály }\end{array}$ \\
\hline $\begin{array}{l}\text { NILD Phonological } \\
\text { Awareness Skills Survey } \\
\text { adaptálása (2009) }\end{array}$ & $\begin{array}{l}\text { rímképzés } \\
\text { szótagelhagyás } \\
\text { szókezdő beszédhang vagy hangcsoport } \\
\text { leválasztása } \\
\text { szótagszintézis } \\
\text { beszédhang-izolálás } \\
\text { beszédhangszintézis } \\
\text { beszédhang-szegmentálás } \\
\text { hosszú beszédhang azonosítása } \\
\text { beszédhang-manipuláció }\end{array}$ & $\begin{array}{l}\text { első és második } \\
\text { évfolyam }\end{array}$ \\
\hline $\begin{array}{l}\text { 3DM-H } \\
\text { (Tóth et. a. 2014; Tóth, 2012) }\end{array}$ & $\begin{array}{l}\text { olvasás (gyakori, ritka és álszavak } \\
\text { megnevezési teljesítménye) } \\
\text { helyesírás } \\
\text { fonématudatosság (fonématörlés } \\
\text { egyszótagú szavak segítségével) } \\
\text { betű-hang megfeleltetés } \\
\text { gyors automatikus megnevezés }\end{array}$ & 1-4. évfolyam \\
\hline
\end{tabular}


(betúlisták, számok, vonalas ábrák)

nyelvi emlékezet (beszédhang- es

szótagterjedelem)

téri-vizuális emlékezet (vizuális

szekvencia és Corsi-kocka)

választásos reakcióidő (vizuomotoros

koordináció)

\section{3. A hazai és nemzetközi mérési tendenciák hasonlóságai és különbözőségei}

A hazai és nemzetközi (jelen esetben angol nyelvü) mérési tendenciák különbözőségei főként a két nyelv, valamint az olvasástanítás különbségei adják (1. táblázat). Az angol nyelvterületen a gyermekek már az általános iskolai oktatást megelőző évben olvasni és írni tanulnak, ennek hatására a fonológiai tudatosságuk fejlödése felgyorsul. Van Tilborg, Segers, van Balkom, \& Verhoeven (2018) megállapítása szerint a gyermekek már óvodában a mondókákon keresztül felismeri, hogy a hangokkal manipulálni lehet, illetve arra is rávezetik, hogy a különböző hangokat, különböző betűk reprezentálják. Pullen \& Justice (2003), valamint Storch \& Whitehurst (2002) munkái kitérnek arra, hogy az formális olvasástanítás előtt a gyermekek esetében kialakul a betü-beszédhang megfeleltetés, valamint a szavak dekódolásának képessége.

Míg hazánkban az óvoda-iskola átmenet során megvalósuló tesztek a beszédhangok azonosítását és differenciálását, az azokkal való manipulációt vizsgálják, addig nemzetközi szinten ugyanezen korosztály számára megjelennek a gyors automatikus megnevezés, a betübeszédhang megfeleltetést, a nyomtatott szöveg ismeretét kérő feladatok is. Ebből a szempontból a nyugati mintát követi Csépe (2013) és Tóth (2012) munkája is, hiszen a 3DM-H tesztben már megjelenik a gyors automatikus megnevezés, melynek több változatával is dolgoznak. A gyors automatikus megnevezési feladatok számos változata ismert (Logan, Schatschneider és Wagner, 2011; Wolf és Bowers, 1999), a képek megnevezéséhez nem minden esetben szükséges betü, illetve számismeret, a nyomtatott szöveg ismerete átmenetet képez, föként a szövegben való tájékozódás vizsgálatát tüzi ki célul, addig a betü-beszédhang megfeleltetés már valóban az grafémák és fonémák összekapcsolásának meglétét feltételezi.

Összességében elmondható, hogy a 2. fejezet a fonológiai tudatosság mérésének széles spektrumát lefedi, viszont sem a hazai, sem a nemzetközi tesztek és tesztrögzítési módszerek nem mutatnak egységes képet. A tesztek standardizálásának kérdésköre, az értékelési kritériumok eltérései, valamint a teszt rögzítésének eltérő volta számos kérdést von maga után. Szintén szembetünő a tesztelési környezet változékonysága is, illetve az is, hogy a tesztet 
rögzítő személy milyen képzettséggel rendelkezik, illetve mennyi segítséget kap az adatok értelmezéséhez, illetve a későbbi fejlesztési terv kialakításához. 


\section{A FONOLÓGIAI TUDATOSSÁG ONLINE MÉRÉSI LEHETÖSÉGEI}

\section{1. Az innovatív itemformátumok kidolgozása - áttérés az élőszavas tesztfelvételről az online tesztelésre}

A Rathvon (2004) által megállapított kritikus problémakörök (a feladatok sztenderdizálásnak hiánya, a feladatok prediktív validitásának relatív volta, valamint a vizsgáztatói és pontozói variancia) kiküszöbölésének egy lehetséges módja, hogy olyan objektív mérőeszközt készítsünk, mely rögzítési folyamatára és értékelésére a mérőbiztos személye és a pontozói variancia nem lehet befolyással, illetve olyan mérőeszközt fejlesszünk, melyben a fonológiai tudatosság vizsgálata során kiemelten fontos hangzó utasítás azonos módon jelenik meg minden feladat során. Erre kínál lehetőséget az online tesztelés.

A Szegedi Tudományegyetem Oktatáselméleti Kutatócsoportja olyan online mérőrendszert dolgozott ki, mely már óvodától kezdve egészen az egyetemi alkalmasság mérésig magában foglaló teszteket tartalmaz. Az eDia rendszer (Molnár, 2015) tesztjeinek csupán egyetlen szeletét képezi az anyanyelvi műveltség, az iskolakészültség vagy olvasásszövegértés mérése. A szemtől szembeni tesztelésről az online tesztelésre való áttérés viszont a feladatok újragondolására sarkallta a tesztek megalkotóit. A két mérési módszer közti különbségek/változások főként a feladattípusok és válaszadás módjának, a mérőbiztos feladatkörének és a tesztelés körülményeinek megváltozása köré csoportosíthatók. A két tesztfelvételi típus jellemzőire az 9. táblázat hívja fel a figyelmet.

9. táblázat. Az élöszavas tesztfelvétel és az online tesztelés jellemzői

Élőszavas tesztfelvétel

Online tesztelés

Artikulációs problémák

Nonverbális ráhatás

Elöre rögzített hanganyag

Szubjektivitás térnyerése

Megváltozott mérőbiztos 
Az élőszavas, azaz szemtől szembeni tesztfelvétel során teljes mértékben a mérőbiztos irányítja és esetenként befolyásolhatja a tesztelés menetét. Az ilyen típusú adatrögzítésre az egyéni tesztfelvétel jellemző, tehát a mérőbiztos egyszerre egy gyermekkel/tanulóval foglalkozik. Az egyéni tesztelés nemcsak jelentős időtöbbletet okoz, hanem megnövelheti a gyermekben jelentkező esetleges, a tesztelés során fellépő frusztráció lehetőségét is. Az élőszavas tesztelés során a gyermek/tanuló nemcsak hallja az adott feladatra vonatkozó utasítást, hanem látja is a mérőbiztost. Ezen két releváns szempont tükrében figyelembe kell venni a mérőbiztos részéröl jelentkező esetleges artikulációs, hangképzési problémákat, nehézségeket, illetve a szintén a mérőbiztos felöl érkező nonverbális ráhatást, valamint a válaszadás során jelentkező esetleges félrehallást. Ezen tényezők együttesen, de akár különkülön is jelentősen befolyásolhatják a gyermekek teszten elért teljesítményét, akár a mérőbiztos beszédprodukciója, akár percepciója kapcsán.

Molnár (2016) kilenc szempont alapján osztályozza a technológiaalapú mérés hatékonyságát. Munkájában kiemeli (1) a tesztelés gazdaságosságát, (2) a tesztszerkesztés változatosságát, (3) az azonnali, objektív és standardizált visszacsatolás lehetőségét, (4) a tanulók motivációjának változását, (5) az innovatív feladatszerkesztési lehetőségeket, (6) az adaptív tesztelés lehetőségét, (7) a tesztelésbe bevonhatók körének bővülését, (8) a kontextuális adatok hatékony rögzítését és elemzését, valamint azt, hogy (9) az innovatív tesztelés során tesztek jóságmutatói javulhatnak. Ezen szempontok mentén kijelenthető, hogy az óvodai és kisiskolai tesztelés során is egyértelműen érvényesülnek a felsorolt szempontok. A tesztelés valóban gazdaságos, hiszen míg a szemtől szembeni tesztelések során a tesztrögzítő egyszemélyben hangoztatja a példaanyagot (az előre megvásárolt/nyomtatott/másolt papíralapú feladatlapról), majd a válasz pontosságát írásban rögzíti (az előzőleg vásárolt/szokszorosított) értékelő lapon, addig az online rendszeren egyszerü internetkapcsolattal elérhetővé válnak a tesztek, a mérőbiztos pedig csupán felügyelői szerepet tölt be. A tesztszerkesztés változatosságának köszönhetően dolgozhatunk statikus és dinamikus elemekkel, melyekre 
kattinthatnak, és melyeket vonszolhatnak a gyermekek/tanulók. Az azonnali visszacsatolásnak köszönhetően a válaszokat a rendszer azonnal rögzíti, melyek azonnal lekérhetők, elérhetők az online felületen, így nem kell várni a manuális kiértékelésre, illetve az eredmények feldolgozásának hibaszázaléka is jelentősen csökken. Az online tesztelés során a gyermekek/tanulók előre rögzített hanganyaggal dolgoznak. A rendszer beállításainak köszönhetően a hang indítására, indulására többféle lehetőség kínálkozik. Egyrészt a teszt szerkesztői dönthetnek amellett, hogy a gyermek/tanuló maga indítja el a hangfájlt, illetve amellett is, hogy a hang magától induljon el akár az adott feladat megjelenése idejében, de akár beállíthatja azt is, hogy a hang bár automatikusan induljon, mégis a feladat betöltésétőlszámított néhány másodperc elteltével (ezt a rövid, néhány másodpercnyi időtartamot szintén a teszt készítői határozzák meg). A hangok esetében további beállításként szerepelhet, hogy az adott utasítás és példa hányszor váljon meghallgathatóvá. A nyelvi képességek vizsgálata során a szemtől szembeni felvételek esetében is találhatunk olyan kritériumot, mely érinti az ismétlések számát, illetve korlátozza azt. A DIFER beszédhanghallás résztesztje esetében a feladat elhangzása után egyszeri ismétlés megengedett, ugyanúgy, mint a szemtől szembeni adafelvétel esetében (Nagy, Józsa, Vidákovich, \& Fazekasné Fenyvesi, 2004). Az online rendszerben az ismétlések száma szintén korlátozható, beállítható. A válasz helyessége vagy esetleges helytelensége mellett arra is kapunk visszajelzést az adatokból, hogy a gyermek mennyi időt töltött a feladatban, ha esetleg nem pontot érő válaszra kattintott, akkor melyik disztraktort választotta, módosított-e a válaszán, valamint arra is, hogy mennyi idő alatt ért végig a teszten. Ezen tényezők az élőszavas felvétel során bár megfigyelhetők, de rögzítésre, többségében, nem kerülnek. Egyedül Jordanidisz (2011) számol be arról, hogy a szemtől szembeni tesztrögzítés során rögzítette a gyermekek válaszát akkor is, ha azok nem az elvárt választ tükrözték. A gyermekek az innovatív eszközzel történő tesztelést játékként fogják fel, gyakran saját példájukat mesélik, hogy ők mit, hogy szoktak játszani ezen eszközök segítségével (Kiss, 2016). Csapó, Molnár, \& Nagy (2015) a Difer teszt online adaptációjával végzett vizsálatok során, a tradicionális szemtől szembeni vizsgálat megbízhatósági mutatójához képest (Cronbach- $\alpha=0,89)$, közel 0,5-el magasabb értéket tapasztaltak (Cronbach $-\alpha=0,94)$ az általános iskola első osztályos tanulók körében.

Összességében elmondható, hogy a Molnár (2016) által felállított, az online tesztelésre vonatkozó kategóriák mentén az online tesztelés rejtette lehetőségek széles skálája megragadható. Alehetőségeknek kiaknázása egy pontosabb, részletesebb képet biztosít a gyermekek/tanulók teljesítményéről. Azt viszont nem szabad figyelmen kívül hagyni, hogy a többletadatok kizárólag abban az esetben vezethetnek pontosabb fejlesztési lehetőséghez, ha az 
adatokat valóban értelmezni tudó és a kínálkozó lehetőségekkel valóban élni tudó pedagógusok alkalmazzák és hasznosítják az online tesztelés nyújtotta lehetőségeket.

\section{2. A fonológiai tudatosság feladatai az élőszavas tesztelés során}

Az élőszavas, szemtől szembeni tesztek közös jellemzője, hogy hangzó utasításra épülnek, a méröbiztos személyes jelenlétét és aktív közremüködését követelik, valamint a gyermek a mérőbiztos kérésére, kérdésére, a feladat típusától függően főként verbális választ ad. Az élőszavas tesztfelvétel egyik legérzékenyebb pontja a fonológiai tudatosság részét képező, a hangok kihallására, differenciálására vonatkozó feladatok felvétele. A fonológiai tudatosság feladatai, hasonlóan a többi szemtől szembeni tesztfeladathoz, verbális választ követelő, vagy a válaszadás módját tekintve tapsolást, kopogást, szóalkotást kérő feladatokként jelentek meg, esetleges bábok, vagy egyéb játékos elemek bevonásával (pl. Józsa, Steklács, Hódi, Csíkos, Adamikné, Molnár, Nagy, \& Szenczi, 2012; Nagy et al., 2004; Adams, Treadway, \& CTB/McGraw-Hill, 2000). A manuális segédeszközök mennyisége és formája természetesen függ a vizsgált korosztály életkori sajátosságaitól. Az online mérések során a szemtől szembeni, esetenként nyílt végű feladatokat olyan zárt itemekké alakítottuk, melyekre kattintással vagy vonszolással is megbízható választ kaphatunk. Jelen fejezetben a fonológiai tudatosság azon feladattípusait tekintjük át, melyek a szemtől szembeni mérési gyakorlat szerves részét képezik (1. melléklet). Azon itemtípusok, melyeket az online mérőeszköz során nem kerültek kifejlesztésre, az élőszavas feladatok bemutatása során sem szerepelnek. Ezáltal a fejezet kizárólag a fonológiai tudatosság (1) szótag- és fonémaszintézis, (2) szótag- és fonémaszegmentálás, (3) szótag- és fonématörlés, valamint (4) fonémaazonosítás részterületeire szorítkozik.

A szótagszintű tudatosság a fonológiai tudatosság fejlődésének korai szakaszában kialakul. Az óvodai gyakorlatok, foglalkozások egészen kiscsoporttól előszeretettel alkalmazzák körjátékokra, ritmikus mondókákra, játékos feladatokra épülő fejlesztését, gyakorlását. A feladatok összetételüket, felépítésüket tekintve azonos elméleti alapokon nyugszanak, a pedagógus kreativitásán múlik, hogyan színezi, milyen kontextusba ülteti azokat, szóban közli a hívószavakat, példákat, vagy képek, memóriajátékok, találós kérdések kapcsán vezeti rá a gyermekeket a feladatok példaanyagára. A szótagszintézis feladat szemtől szembeni felvétele során a pedagógus szótagjaira tagoltan mondja a szót, a gyermek feladata pedig a hallott szótagok szóvá történő összekapcsolása. Az óvoda nagycsoportos, illetve általános iskola első osztályos tanulói számára a mérési gyakorlat 2-4 szótagos szavak szintetizálást 
javasolja (Józsa et. al., 2012). A szegmentálás feladatok az élőszavas tesztelés során főként szótagszámlálásként jelennek meg. A gyermek/tanuló akár az adott szó elhangzása után számmal (verbális válaszadás), vagy a szótag számát lekopogva, a megfelelő számú ujj, pálcika vagy figura segítségével (nem verbális válaszadás) adja meg válaszát. Egyes gyermekek esetében az említett módszerek együttes alkalmazása is megfigyelhető. A szótagtörlés feladatok esetében szintén a pedagógus/mérőbiztos kérésére szóban válaszol a gyermek, elhagyva a hívószó első vagy utolsó szótagját. A mérési módszertan alapján a gyermek/tanuló előbb kimondja a szót, majd verbális választ ad. Az említett feladatok során a gyermek semmilyen vizuális ingert nem kap, nem látja az adott feladatlapot, kizárólag a kérdező hangját hallja, manuális segédeszközök esetleg a szótagok számlálása, a szegmentálás feladatok esetében megjelenhet.

A fonémaszintü feladatok (szintézis, szegmentálás, törlés) (1. melléklet) módszertanilag ugyanazon sémára épülnek, mint a szótagszintü feladatok. Abban az esetben, ha gyermek/tanuló betüismerete már kellőképp fejlett, a fonémaszintü müveleti feladatok megoldása összekapcsolható a betü-beszédhang megfeleltetési feladatokkal. Ez az összekapcsolás megfelelőképpen alkalmazható a fonémaszintézis feladatok esetében, hiszen kérhetjük a tanulót a hívóhangok leírására és azon keresztüli összeolvasására. Természetesen a feladat az olvasni/írni nem tudó gyermekek esetében vizuális segédlet/segítség nélkül szóban is megválaszolható. A manuális segédeszközök használata a szegmentálás feladatok esetében megkönnyíthetik a válaszadást, hiszen ebben az esetben szemléltetést, vagy szemléltetéssel egybekötött verbális választ várunk a gyermektől. Természetesen a számlálást kérő feladatok esetében a matematikai tudást, azaz föként a számok és mennyiségek kapcsolatát nem szabad figyelmen kívül hagyni. Juhász \& Radics (2017) az ujjpercepció fontosságát emeli ki elemek számolása kapcsán. Munkájukban megállapítják, hogy az ujjak segítenek a belső, néma számlálás esetében (Geary, 1995), illetve tehermentesítik a munkamemóriát is. Az ujjakkal való manipuláció megtiltása, megakadályozása a válaszadás során nagyobb hibaarányt vont magával (Alibali \& DiRusso, 1999). A törlést kérő feladatoknál a kezdő- vagy véghang elhagyásával kell az újonnan képzett szót kiejteni, míg az azonosítás feladatok esetében a gyermek verbális választ ad arra a kérdésre, hogy hallja-e az adott hangot a szóban, vagy sem.

A szemtől-szembeni tesztelés tehát vagy tisztán verbális válaszadással vagy a verbális és manuális válaszadás összekapcsolásával jelenik meg előre megalkotott feladatokon keresztül. A feldatok metódusa egyhangú és monotón, a feladat utasítását, illetve a példaszót, hívóhangot a vizsgálatot végző, többnyire pedagógus, közli, majd a gyermek válaszol. A feladatok 
módszertana a müveleti szintek mentén, a nyelvi egység méretétől függetlenül azonosságot mutathat.

\section{3. A mérőbiztos szerepének megváltozása az online tesztelés során}

A különbözö típusú mérőeszközök más-más méröbiztosi felkészültséget igényelnek. Az élőszavas tesztfelvétel során a mérőbiztos a gyermekkel szemben ül, többnyire zárt, csendes teremben. A mérőbiztos és a gyermek látják egymást, olvashatnak egymás mimikájából, gesztusaiból, testtartásából. A rögzítendő tesztet az óvópedagógus akarata ellenére is manipulálhatja, hanglejtésével, nonverbális jelekkel sugalmazhatja a helyest választ a gyermek felé, de akár egy kezdetleges megfázás vagy rekedtség is befolyásolhatja a pedagógus hangprodukcióját és így a gyermek teszten nyújtott teljesítményét, valamint a teszt objektivitását is. A mérőbiztosnak továbbá nemcsak saját hangjának monotonitására, gesztusainak leküzdésére kell koncentrálnia, hanem az eredmények pontos rögzítésére is. Ezen szempontok alapján elmondható, hogy a tesztfelvétel sok időt, koncentrációt és önfegyelmet követel az óvópedagógustól. Az online tesztelés során a gyermekeket alacsony létszámú csoportokban mérjük, a tesztet a közvetítő médium hatására pedig játékként fogják fel (Kiss, 2016). A méröbiztos feladatköre megváltozik, a mérések ideje, a csoportos rögzítési formát figyelembe véve, jelentősen csökken. A feladatokra adott válaszokat a mérőbiztosnak nem kell rögzítenie, a rendszer tárolja azokat (Molnár, 2016). Ezen eredmények később excel táblázatként lekérhetők a rendszerből. A feladatokat a mérőbiztosnak nem kell felolvasnia, hanem az elöre rögzített hanganyag segítségével minden gyermek ugyanazt a hangot, ugyanazt a példát hallja, melyet a gyermek önmagának, egy hangszórógombra való kattintással indít. A mérőbiztos így kizárólag a gyermeket segíti tesztelés közben, megfigyeli reakcióit, értékelést készít a gyermek feladattartásáról, feladatokhoz való viszonyulásáról. A mérőbiztos már nem a teszt tényleges felvétele során játszik kiemelkedő szerepet, hanem az eredmények értékelésében, és az eredményekre épülő fejlesztési terv kidolgozásában (Kiss, 2016).

\section{4. A közvetítő médium hasonlóságai és különbözőségei az óvodai és általános iskolai környezetben}

A tesztek kialakítása során mind a két közvetítő médium által kínált lehetőségeket és az asztali gép és a tablet közti különbségeket is figyelembe kellett vennünk (10. táblázat). A feladatok tervezése során meghatározó tényező az eltérő képernyőfelbontás, illetve az asztali gépek monitora és a tabletek képernyője közti méretkülönbség. A számítógépes tesztelés 
esetében a navigálás egér segítségével történik. Ebben az esetben a tanulónak rendelkeznie kell a megfelelő kéz-egér koordináció képességével, fel kell ismernie az összefüggést az egér mozgatása és a képernyőn megjelenő kurzor mozgása között. A tabletes tesztelés során a gyermekek viszont közvetlen kapcsolatba kerülnek a képernyővel, így ujjuk kiváltja az egér funkcióját (Molnár, 2016).

Az óvodai tabletes tesztelés előrelépést jelent a korábbi óvodai, szemtől szembeni, élőszavas tesztfelvételhez képest, viszont az egyszerre, egy helyszínen mérendő gyermekek számát tekintve nem versenyezhet az általános iskolai, középiskolai vagy akár egyetemi bemeneti mérésekkel. Ennek oka kettős: egyrészt a vizsgálatban részt vevő óvodákban nincs kialakított gépterem a gyermekek számára, másrészt az óvodáskorú gyermekek tesztelése során egyéb, a gyermekek korából és óvodai szocializációjából fakadó körülmények is szerepet játszhatnak (pl. nagyobb mértékủ kooperáció a társakkal, rövid egészségügyi szünetek, gyenge feladattartás). A tablettel megvalósuló tesztelés ennek ellenére közvetlenebb, valamint mozgásában szabadságot ad a gyermeknek, hiszen megfoghatja a táblagépet, mozoghat az eszközzel (Kiss, 2016).

10. táblázat. Az asztali gépes (PC-s) és tabeletes tesztelés közti különbségek

\begin{tabular}{ccc}
\hline Szempont & \multicolumn{2}{c}{ Platform } \\
& PC gépterem & Tablet \\
\hline Navigálás & egérrel & tap-eléssel \\
Hangok automatikus indítása & megvalósul & csak részben megoldott \\
Eszközhasználat szabadsága & helyhez kötött & mobil \\
\hline
\end{tabular}

\subsection{A dolgozat elméleti vonatkozásainak összegzése}

A dolgozat három fejezet mentén világít rá a fonológiai tudatosság fogalmára és mérési tendenciáira. A fonológiai tudatosság fogalmi megközelítése (Csépe, 2006; Blomert Csépe, 2012; Torgesen, Wagner \& Rashotte, 1994; Gillon, 2004; Hayes \& Flanigan, 2014) és mérési metódusa változatos képet mutat (6., 7., és 8. táblázat), viszont a kutatások egyetértenek abban, hogy a korai nyelvi képességek ezirányú biztos elsajátítása kulcsfonosságú a későbbi olvasási teljesítmény alakulásában (Blomert \& Csépe, 2012; Nation \& Snowling, 2004), ezért korai monitorozása elengedhetetlen. Az olvasás alappillére a beszélt nyelv és a hangok közti kapcsolat megértése (Wagner \& Torgesen, 1987; Konza, 2014), éppen ezért kiemelkedő 
tényező a szavakkal, szótagokkal és hangokkal végzett tudatos manipuláció. Mivel a fonológiai tudatosság elméleti megalapozása és megalapozottsága, évtizedekre nyúlik vissza, ezért az elméleti rész ennek kiaknázására egy fejezetet szentel, melyben részletezi az elméletek, megközelítések sokszínűségét.

A dolgozat újdonságát maga az online tesztelés adja, ezért az elméleti áttekintés jórészt a hazai és nemzetközi mérőeljárások jellemzőit, valamint a szemtől szembeni és online tesztelések módszertani kérdéseit taglalja. A mérőeszközök jellemzése során egyértelmüen látszik az, hogy a fonológiai tudatosság mérése többnyire egy-egy résztesztjén keresztül valósul meg, mely résztesztek változatos tesztkörnyezetben, eltérő korcsoportok bevonásával, illetve eltérő technikai feltételek mellett valósulnak meg. Szemtől szembeni vizsgálatok esetében megjelennek a konstruktum vizsgálatát lefedni törekvő mérőeszközök (8. táblázat). Hazánkban eddig nagymintás, a fonológiai tudatosság egy résztesztjét lefedő online mérés a DIFER beszédhanghallás résztesztjével valósult meg (Csapó, Molnár \& Nagy, 2014), illetve szintén online környezetben egy, a fonématörlés müveletére fókuszáló mérőeszköz ismert (Tóth et. al, 2014; Tóth, 2012). A fonológiai tudatosság és a mentális lexikon fejlettségének online vizsgálatára Szili (2016a; 2016b; 2016c), valamint Szili \& Pásztor (2013) munkája világít rá. Az online tesztelések viszont az általános iskola kezdő évfolyamait fedték le, az óvodai korosztály tesztelésére nem szorítkoztak.

Az elméletek és mérőeszközök sokszínüségének feltárása biztos alapot nyújt egy olyan online fonológiai tudatosság teszt kialalkítására, melyben szótag- és fonémaszintü, innovatív és változatos feladatok jelennek meg. A fonológiai tudatosság fejlődése, valamint a gyermekek IKT-eszközökkel való familiaritása lehetőséget nyit az óvodai online tesztelés kialakításához. 


\section{AZ EMPIRIKUS VIZSGÁLATOK KONCEPCIÓJA}

\section{1. A kutatás céljai, fontossága, kutatási előzmények}

A dolgozat keretein belül bemutatásra kerülő mérőeszközök a tesztfejlesztési folyamat szerves részét képezik, mely során célunk egy, a 21. század digitális kihívásait figyelembe vevő, innovatív, az iskolaérettség kognitív feltételeit vizsgáló mérőeszköz kidolgozása. Ezen feltételrendszer elengedhetetlen része a fonológiai tudatosság vizsgálata. A fonológiai tudatosság egy kiemelkedően fontos része, a fonémaazonosítás vagy a beszédhanghallás (tehát a fonémák különböző hangkörnyezetben és különböző szóbeli pozícióban/pozíciókban történő azonosítása és/vagy differenciálása) jelenleg is az iskolaérettség kognitív kritériumainak részét képezi.

A dolgozatban szereplő empirikus vizsgálatok (11. táblázat), mivel két közoktatási színtér, az óvoda és az általános iskola közti átmenet megvalósulását hivatottak lefedni, az óvoda nagycsoportjában, a koruk szerint iskolaérett gyermekek körében és az általános iskolák első osztályában zajlottak. A két szintér mérési módszere között is jelentős eltérés mutatkozott, hiszen míg az általános iskolai online mérések módszertana már a vizsgálatok kezdetekor kidolgozott volt, addig az óvodai online mérések még hiányterületnek számítottak. Így a kezdeti, 2014-es óvodai vizsgált során ezt a hiátust is pótoltuk.

Az ütemezésből látszik, hogy 2014 februárja és decembere közös több tesztváltozatot rögzítettünk. A teszteket a dolgozat fő részét képező fonológiai tudatosság teszt előkészületei során, előkészítésében, illetve az óvodai online mérés technikai feltételeinek megalapozásában játszottak szerepet. Az első, óvodai tabletes tesztelések részét képezte egy fonológiai tudatosság teszt kidolgozása, valamint a Token teszt gyermek változatának részbeni, online felületre történő adaptálása. A fonológiai tudatosság teszt a szótagok és fonémák azonosítására fókuszált. A teszt 107 középső (átlagéletkor=4,85, szórás=0,27) és 137 nagycsoportos gyermek (átlagéletkor=5,81, szórás $=0,31$ ) részvételével megbízhatónak bizonyult (Kiss, 2015; Kiss \& Patai, 2015a, 2015b). A Token teszt során a gyermek öt különböző színü (kék, zöld, sárga, fehér és piros) kört és négyzetet lát két leosztási formában. A kezdeti vizsgálatban az A elrendezést alkalmaztuk, melyben a körök és a négyzetek egyazon méretüek, öt négyzet és öt kör szerepel egy sorban. A tesztet, a fonológiai tudatosság teszttel, egyazon mintán rögzítettük. A teszt megbízhatónak bizonyult (Cronbach- $\alpha=0,82$ ). A Difer teszt online változatával történt vizsgálatokon 244, koruk szerint iskolaérett gyermek vett részt, a teszt online változata megbízhatónak bizonyult (Cronbach- $\alpha=0,90)$. Az online fonológiai tudatosság teszt, illetve 
Difer teszt beszédhanghallás résztesztjének rögzítése a fonológiai tudatosság konstruktumán belüli vizsgálatok kapcsán egyértelmü elfeltételként értelmezhető a későbbi tesztek kialakításához, viszont a Token-teszt adaptációja és az előkészületi szakaszon történő vizsgálata kérdéseket vonhat maga után. A teszt adaptálásának mind elméleti mind gyakorlati volnatkozásai relevánsak. Figyelembe véve a beszédmegértés hierarchikus felépítésű modelljét (Gósy, 2005) feltételeztük, hogy a beszédészlelés megfelelő szintű fejlettsége elengedhetetlen a Token teszttel vizsgált beszédmegértés rész teljesítéséhez, illetve folyamatban lévő vizsgálataink arra is kiterjednek, hogy a fonológiai tudatosság és a Token-teszten nyújtott teljesítmények közötti kapcsolatot feltárjuk. A munka technikai, gyakorlati oldalát tekintve pedig rávilágított arra, hogy megfigyeléseink alapján az itemek vonszolása a tablet érintőképernyőjén nem okoz gondot az óvodás korosztály számára sem. Összességében elmondható, hogy a három teszt óvodai mintán történő rögzítése teljeskörű rálátást biztosított az innovatív tesztelési módszer elméleti és gyakorlati oldalára egyaránt. A kezdeti vizsgálatok tehát nemcsak kizárólagosan a gyermekek képességeinek feltérképezésére irányultak, hanem a tesztek új típusú környezetben való müködésének, létjogosultságának megállapítására is, hiszen a megváltozott közvetítő médium, valamint a szemtől szembeni tesztelés felváltó innovatív forma, a feladatok újragondolását követelte a tesztek fejlesztőitől is.

A kezdeti vizsgálatok tapasztalatait összegezve 2015 őszétől az új típusú iskolakészültség méröeszközcsomag kidolgozásán és fejleszésén dolgoztunk, melynek három pontban történő bemérését és a teszt fejlesztésének lépéseit, illetve az egyes mérési pontokon tapasztalt eredményeket az ötödik, a hatodik és a hetedik fejezet vonatkozó részei mutatják be. Ezáltal jelen dolgozat kitér az óvoda-iskola vizsgálata során alkalmazott mérőeszközök jellemzésére, a mérőeszközökben jelentkező korlátok és lehetőségek feltárására, valamint egy új típusú tesztbattéria részét képező, a fonológiai tudatosság online vizsgálatára szorítkozó teszt fejlesztési folyamatára. A tesztfejlesztési folyamat célja egy, a pedagógusok számára is könnyen alkalmazható, a fonológiai tudatosság vizsgált részképességeit objektíven mérő, játékos mérőeszköz kidolgozása, mely megbízhatóan méri az óvodás gyermekek és első osztályos tanulók képességeit. Célunk továbbá a mérőeszköz segítségével megkönnyíteni a pedagógusi mérési gyakorlatot, hiszen tapasztaltuk, hogy a pedagógusokra nagy és monotón terhet ró a tesztek időközönkénti rögzítése, az objektív tesztfelvétel, illetve a mérési útmutatóban szereplö összes szempont folyamatos követése. 


\section{1. táblázat. A dolgozatban szereplö méröeszközök megnevezése és felvételének ütemezése}

\begin{tabular}{cc}
\hline Ütemezés & Kutatási tevékenység \\
\hline $\begin{array}{c}\text { A fonológiai tudatosság, a Token teszt, az eDifer és a gyors } \\
\text { automatikus megnevezés tesztek próbamérése óvodás } \\
\text { korosztály körében }\end{array}$ \\
Az új típusú iskolakészültség méröeszközcsomag \\
próbamérése (géphasználat, induktív gondolkodás, az \\
olvasás elökészségei, a matematikai tanulásának \\
előfeltételei) \\
2015 ősze \\
az online iskolakészültség mérőeszközcsomag rögzítése az \\
óvodai korosztály körében \\
az iskolakészültségi mérőeszközcsomag rögzítése általános \\
iskola első osztályos tanulóinak körében
\end{tabular}

Összességében, jelen dolgozat keretein belül bemutatott vizsgálatok két, egymásra építkező részre tagolhatók:

1) Pilotvizsgálatok a fonológiai tudatosság egyes részkészségeinek online vizsgálatára, az online vizsgálatokban rejlő kihívások és lehetőségek feltérképezése az óvodás korosztály körében

2) A fonológiai tudatosság online tesztelése és a teszt fejlesztésének bemutatása az óvodás és kisiskolás korosztály bevonásával

\section{2. Kutatási kérdések}

A kutatási kérdések az online tesztek alkalmazhatóságának és a gyermekek fonológiai tudatosságának mérése köré csoportosíthatók.

I. A mérőeszközökre és a fonológiai tudatosság konstruktumára vonatkozó kutatási kérdések: 
Alkalmasak-e a tesztek az egyes részterületek vizsgálatára az adott korcsoportokban?

Megfelelőek-e a tesztek pszichometriai jellemzői?

Mennyire illeszkedik a tanulók képességszintjéhez a tesztek nehézsége?

Megfelelőek-e a tesztek konstruktumvaliditása?

Milyen összefüggések tapasztalhatók a részterületek között?

II. A fonológiai tudatosság fejlődésére vonatkozó kutatási kérdések:

Hogyan változik a fonológiai tudatosság fejlettsége a vizsgált korcsoportokon belül és a korcsoportok között?

Mely vizsgált részképességek függenek össze leginkább a fonológiai tudatosság fejlődésével?

III. A fonológiai tudatosság mérésére és a háttérváltozókra vonatkozó kérdések:

Befolyásolja-e a közvetítő médium használatának képessége a fonológiai tudatosság teszten elért teljesítményeket az óvodai és általános iskolai korcsoporton?

Milyen összefüggések és különbségek jelennek meg az egyes háttérváltozók tekintetében?

\section{3. Hipotézisek}

I. A mérőeszközökre és a fonológiai tudatosság konstruktumára vonatkozó hipotézisek:

H1: A tesztek megbízhatóan becslik az óvodás gyermekek és az általános iskola első osztályos tanulóinak fonológiai tudatosságbeli fejlettségét, a tesztek pszichometriai mutatói megfelelök. A fonológiai tudatosság azonos korosztálya számára fejlesztett mérőeszközök mind szemtől szembeni, mind a képesség mérésére adaptált online, számítógép alapú tesztváltozatok megbízhazóan alkalmazhatók a konstruktum vizsgálatára (Jordanidisz 2011; Csapó, Molnár \& Nagy, 2015).

H2: A teszt belső konstruktumának vizsgálata alapján (CFA) a vizsgált nyelvi egység mérete és a nyelvi egységgel végrehajtott müvelet mindkét korosztály esetében együttesen határozzák meg a teszten nyújtott teljesítményt. A fonológia tudatosság konstruktumának vizsgálata nem mutat egységes képet, hiszen a mérőeszközök különböző korú és összetételü mintával, valamint a fonológiai tudatosság különböző résztesztjeit lefedő mérőeszközökkel dolgoznak 
(Schatsneider, Francis, Foorman, Fletcher, \& Mehta, 1999; Yopp, 1988; Stahl \& Murray, 1994; Kiss, Hódi, Tóth, \& B. Németh, 2016)

II. A fonológiai tudatosság fejlődésére vonatkozó hipotézisek:

H3: Az általános iskola első osztályos gyermekek teszten nyújtott átlagteljesítménye magasabb lesz, a közoktatás két színtere közti fejlödés kimutathatóvá válik. Ez a fejlődés nem feltétlen érinti a fonológiai tudatosság minden, a résztesztek által vizsgált területét. Az eddigi szemtől-szembeni vizsgálatok alapján megállapítható, hogy szótagtudatosság spontán és folyamatosan, a fonématudatosság, az olvasástanítás hatására jelentkező ugrásszerüen fejlődik (Jordanidisz, 2017), így feltételezzük, hogy az általános iskola első osztályos tanulók magasabb teljesítményt érnek el az online teszteken is.

H4: Az óvodai és az első évfolyamos minta életkori csoportjain belül is kimutatható különbség lesz a fonológiai tudatosság fejlettségében. A közoktatás két színtere számos életkori csoport olvasztótégelyeként szolgál. A legfiatalabb és a legidősebb gyermekek, tanulók életkora között több év különbség lehet. A fonológiai tudatosság fejlődését számos olyan tényező befolyásolhatja, melyek nem a közoktatási színterekhez köthetők, és meghatározhatják a fejlődését, fejlettségét. Ilyen komponens lehet többek közt a szókincs (Oluette \& Haley, 2013) és a formális írás-olvasás tanítás (Skibbe, Grimm, Bowles \& Morisson, 2012). Bár a dolgozat ezeket a szempontokat nem tárta fel a vizsgálatok során, a fonológiai tudatosság fejlettségére, fejlődésére való hatásának feltételezése nem hagyható figyelmen kívül.

III. A fonológiai tudatosság mérésére és a háttérváltozókra vonatkozó kérdések:

H5: A közvetítő médium használatának képessége (PC vagy tablet) sem az óvodai sem az általános iskolai mintán sincs hatással a teszteken nyújtott teljesítményre (Csapó, Molnár, \& Nagy, 2015; Molnár, 2016).

H6: Feltételezzük, hogy az eddigi kutatásokkal összhangban a nemek között teljesítménybeli különbség tapasztalható (Price-Mohr \& Mohr, 2017). Hazánkban az online tesztelés területén a Difer teszt beszédhanghallás résztesztjének eredményei szintén különbségeket mutattak ki az első osztályos lány tanulók javára (Csapó, Molnár, \& Nagy, 2015). 


\section{4. Az empirikus vizsgálatok általános áttekintése}

Mivel jelen munka több kisebb kutatásból áll, ezért ezen fejezet általános áttekintést ad a munka során alkalmazott módszerekről. Az adott kutatásokra vonatkozó részletes jellemzéseket a dolgozat vonatkozó fejezetei tartalmazzák.

A vizsgálatokat óvoda nagycsoportos, valamint általános iskola első osztályos gyermekek körében végeztük. Az óvodai mintát kizárólag a csongrádi megyeszékhely óvodái alkották, önkéntes csatlakozás alapján (12. táblázat). Az általános iskola első osztályos gyermekei mind a 2015-ös, mind a 2016-os mintavétel során az Oktatáselméleti Kutatócsoport partneriskolahálózatának intézményeiből kerültek ki. A 2015-ös mintát 1291 tanuló, míg a 2016-os, első osztályos mintát 4386 tanuló alkotta.

A vizsgálatokban résztvevő gyermekek eloszlását, számát és nemek szerinti eloszlást az 12. táblázat mutatja. A 2015-ös és 2016-os adatgyüjtés folyamán a tesztekbe épített, a gyermekek nemére vonatkozó kérdést maguk a tanulók válaszolták meg, az óvodai adatokat pedig óvodai adatközlés alapján rögzítettük. Az óvodai adatközlés során nem jelentkezett adathiány a gyermekek nemére vonatkozóan, míg az általános iskolai mintavétel során a hiányzó adatok számát a 12 . táblázat Nem válaszolt sora szemlélteti. A minta vizsgálatára vonatkozóan egyéb háttérváltozók nem állnak rendelkezésünkre.

A minta esetében szembetünő lehet, hogy az óvodai korosztály a többi mintához képest kis elemszámmal képviselteti magát. Ennek oka a megváltozott tesztelési környezetnek, a vizsgált gyermekek korának, valamint az infrastrukturális változásoknak is betudható, melyre az 3. fejezet ad magyarázatot.

\section{2. táblázat. A minta összetétele, nemek szerinti bontása}

\begin{tabular}{|c|c|c|c|c|}
\hline & Óvoda & $\begin{array}{l}\text { 1. évfolyam } \\
\text { (2015-ös } \\
\text { adatgyüjtés) }\end{array}$ & $\begin{array}{l}\text { 1. évfolyam } \\
\text { (2016-os } \\
\text { adatgyüjtés) }\end{array}$ & Összesen \\
\hline Fiú & 171 & 616 & 2206 & 2993 \\
\hline Lány & 146 & 567 & 2073 & 2786 \\
\hline Nem válaszolt & 0 & 118 & 107 & 225 \\
\hline Összesen (fö) & 317 & 1301 & 4386 & 6004 \\
\hline
\end{tabular}

A mérőeszközök a fonológiai tudatosság egyes részképességeinek online mérésére szorítkoznak. Az eredeti mérőeszköz, melyet a tesztfejlesztés során módosítunk, 55 itemet tartalmazott. A feladatok két nyelvi szintet (fonéma és szótag), négy műveleti szintet 
(azonosítás, szintézis, szegmentálás és törlés) fedtek le. A szótag szintű feladatok esetében nem tartottuk fontosnak az azonosítás meglétét, hiszen az óvoda nagycsoportjában már fonéma szinten manipulálnak a gyermekek. A feladatok online felületre készültek, végső megjelenési formájuk kialakításában óvó- és fejlesztőpedagógusok is segítségünkre voltak. A kialakítás során fontosnak tartottuk az egyszerü, lényegre törő, ámde gyermekbarát utasításokat és megjelenési formákat (pl. robot, kukac), mégis figyeltünk arra, hogy a színes megjelenési forma ne ragadja el a gyermek figyelmét a megoldandó feladatról. Minden feladat kizárólag hangzó utasítást tartalmazott, melyet a gyermek a feladat képi anyagának betöltésétől számított két másodperc késleltetéssel hallgathattak meg. A késleltetéssel célunk volt, hogy bár kevés, de valamennyi időt biztosítsunk a gyermekek/tanulók számára a képi információ feldolgozására is, ezáltal ne egyszerre terheljük a vizuális és auditív percepciót.

Bár a teszt felépítésében és egy feladattípus vizuális megjelenítésében a két első osztályos mérés között, a tesztfejlesztés eredményeképpen változás történt, a tesztek nyitó (1. ábra) és záró oldala/diája (2. ábra) a tesztelések folyamán ugyanaz maradt. A nyitóoldal a mérési azonosítók beírására szolgál, míg a záróoldalon a tanuló/gyermek százalékos teljesítménye mellett a Malacka által tartott lufik száma is jelzi a tanuló/gyermek teljesítményét.

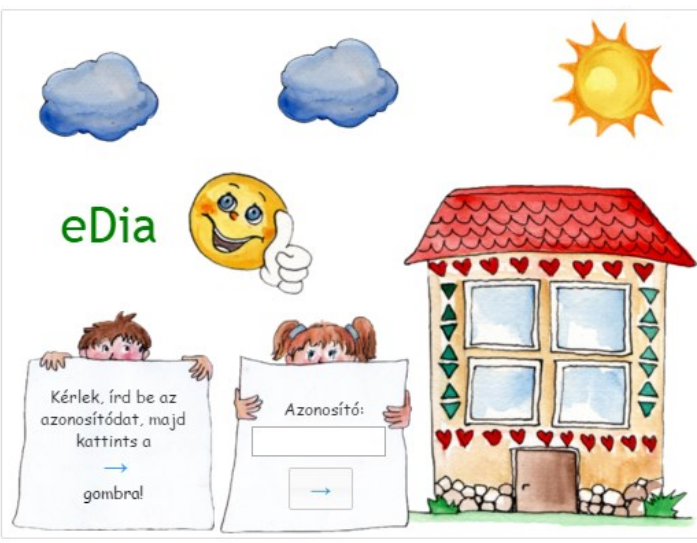

1. ábra

A rögzített tesztek egységes nyitóoldala

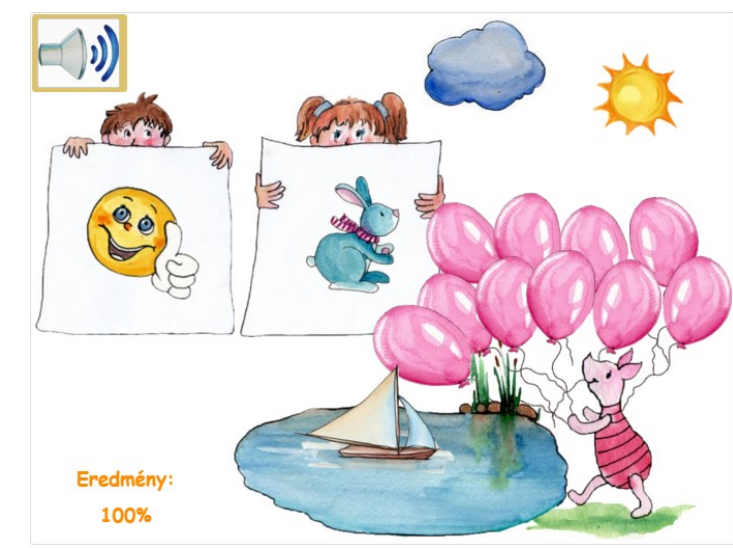

2. ábra

A rögzített tesztek egységes záróoldala

Mindhárom tesztfelvétel esetén közös továbbá, hogy a nyitóoldal után instrukciós diák jelennek meg. Az instrukciós diák célja, hogy felhívják a figyelmet a feladatok közti előrehaladás menetére, azaz a feladat meghallgatása, válaszadás, nyílra történő kattintás hármasára. Az első instrukciós dia (3. ábra) továbbá azt hivatott felmérni, hogy a tanuló megfelelő hangerővel hallja-e a feladatot, hiszen mind az óvodai, mind az általános iskolai 
korosztály feladatai kizárólag hangzó utasításra épülnek, szöveges instrukció egy feladat során sem jelenik meg. A második instrukciós dia (4. ábra) a képernyő tetején lévő narancssárga csíkra hívja fel figyelmet, mely a tesztben való tájékozódást, az előrehaladás ütemét is jelzi, mely a figyelemzavaros, vagy feladattartási nehézségekkel küzdő tanulók számára hasznos támpont lehet a tesztelés során.
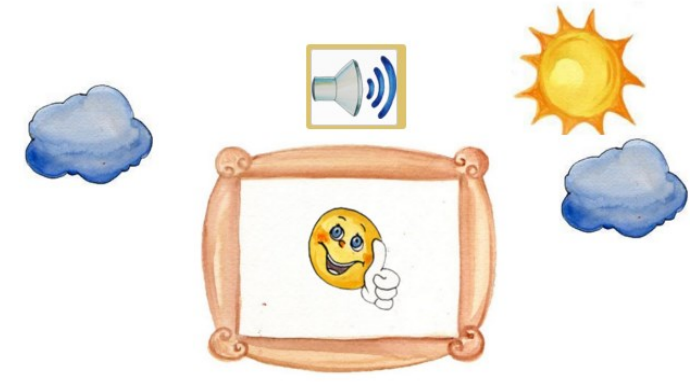

3. ábra

A tesztben való elörehaladást segítő instrukciót tartalmazó dia

Instrukció: Kérlek, játssz velem! Ha az egérrel a hangszóróra kattintasz, megtudod, hogy mit kell tenned! Ha befejeztél egy játékot, akkor kattints a nyílra! Ha túl hangos vagy túl halk a hangom, kérd meg a teremben lévö felnőttet, hogy segítsen beállitani! Ha jól hallod a hangomat, akkor kattints a nyílra!
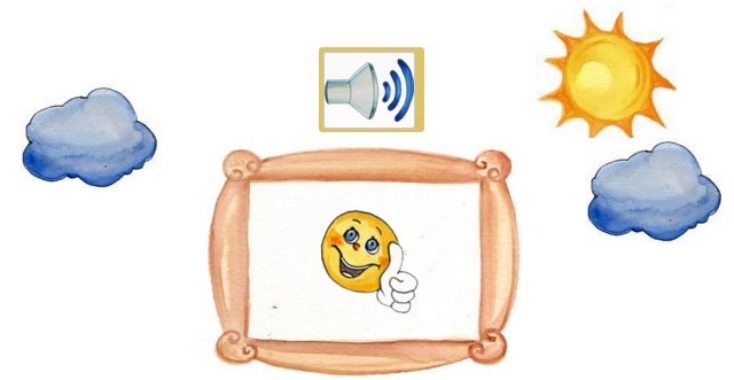

4. ábra

A tesztben való eligazodást segítő instrukciót tartalmazó dia

Instrukció: A képernyő tetején lévő narancssárga csík azt mutatja, hogy hol tartasz a játékban.

Nagyon fontos, hogy mindig figyelmesen hallgasd meg, hogy mi a feladat! Figyelj, mert minden feladatot csak egyszer fogsz hallani! Kezdjük el a játékot! Kattints a nyillra!

A mérőeszköz rögzítése során az óvodai és általános iskolai korosztály esetében különbségek tapasztalhatók. Az általános iskolai korosztály esetében az iskola géptermében, a pedagógusok irányításával történt a tesztfelvétel, közvetítő médiumként asztali gépek jelentek meg, míg az óvodában kis csoportokban (általában 5 fö), hallgatók rögzítették a teszteket, közvetítő médiumként pedig az érintőképernyős eszköz, a tablet jelent meg. 


\subsection{A fonológiai tudatosság mérőfeladatai online tesztelés során}

Az online feladatok kialakítása során az első legfontosabb tényező, mely a feladatok átalakítását is jelentősen meghatározta, a mérőbiztos és a vizsgált személy közti közvetlen interakció iránya. A gyermek/tanuló a feladatok megoldása során nem verbális választ ad, hanem a számítógép/tablet képernyőjén való müveletvégzéssel adja meg válaszát. Az óvodai tesztelés során azt tapasztaltuk, hogy a sztenderd válaszadási módok (tapsolás, ujjakon való számlálás) és az online tappelés, vonszolás akár együtt is megjelenhet, hiszen a szegmentálás feladatok megoldása során többször előfordult, hogy a gyermek a képernyő előtt is tapsolt, vagy az ujjait használta, majd ezután adta meg válaszát.

$\mathrm{Az}$ első online feladataink a szótag és fonémaazonosítást vizsgálták, dichotóm feladatokon keresztül (5. ábra). A gyermek a képernyőn sem az utasítást, sem a hívóhangot, sem a célszót nem látta, csupán hallott inger alapján dolgozott, melyet a hangszórógombra történő kattintással maximum kétszer hallgathatott meg.

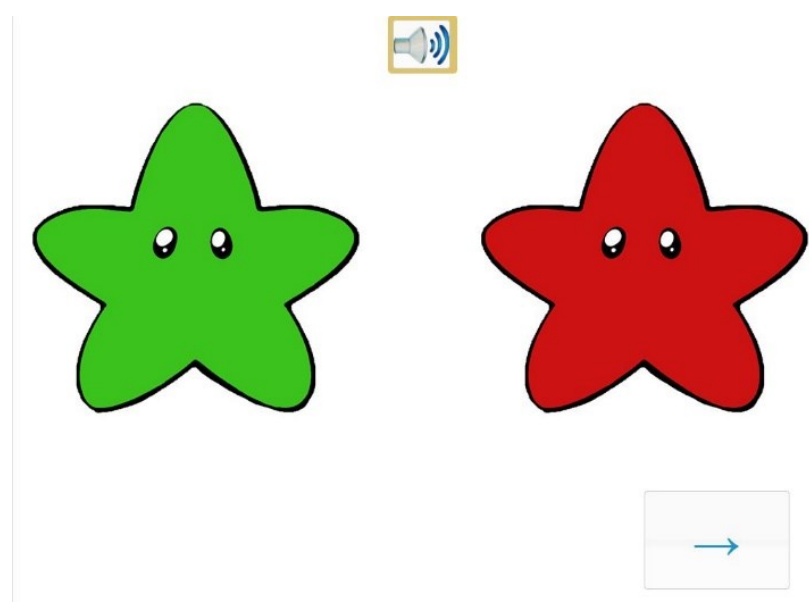

5. ábra

A fonológiai tudatosság online tesztelésének elsö megjelenési formája

A kezdeti dichotóm feladatok után, melyek a nyelvi egységek (szótag és fonéma) azonosítására szorítkoztak a fonológiai tudatosság egyre több részterületét vontuk be, illetve a tappelés (érintés) műveletén kívül a vonszolást is beépítettük. A dolgozat részét képező tesztfeladatok során a hangok meghallgathatóságát már nemcsak kétszeri lejátszásra korlátoztuk, hanem késleltettük is, ezzel elősegítve, hogy a vizuális és az auditív inger ne egyszerre érje a gyermeket. Mivel a mérőeszközök bemutatása során ezek a feladatok szerepelni fognak, ezért jelen fejezetben, csak a technikai megvalósításukra térnék ki. 
A fonémaazonosítási feladatok közül három típust készítettünk. Az első tesztelést követve a fonémák azonosítására szolgáló feladatot (Hallod-e a hangot a szóban? típusú feladat), a kezdeti piros és zöld csillagos megjelenítési formához képest jelentősen módosítottuk (6. ábra). Bár a feladat továbbra is dichotóm maradt, a helyes válasz megjelölését pipával, a helytelenét x-szel helyettesítettük. A helyes és helytelen megoldás közti kontrasztot a pipa zöld, illetve az x piros színével tovább erősítettük. A háttér változékonysága (a bolygó színe a robot lába alatt) tovább segítette a gyermeket azon tény megerősítésében, hogy a nyíl megnyomása utána valóban új feladat következett. A feladat a továbbiakban nemcsak a színek, hanem a háttér formáinak, akár feladatról feladatra történő megváltoztatásával, tovább módosítható.

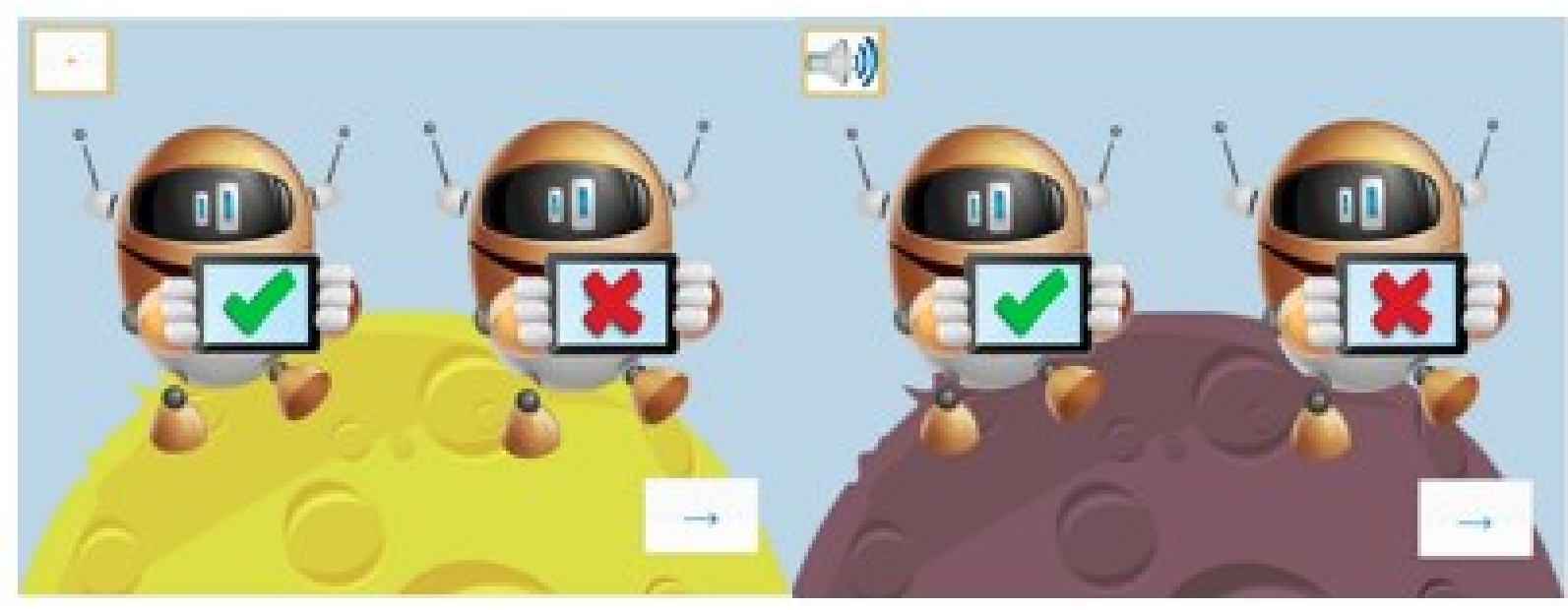

6. ábra

Változatok a fonémaazonositás feladat megjelenitési formájára

A tesztben a hívóhang szóban betöltött pozíciójának meghatározását kérő feladattípus is helyet kapott. A feladatok során arra adtak választ a gyermekek, hogy a hívóhang az adott szó elején, közepén (belsejében) vagy a végén szerepel. Az itemek megjelenítési formájául kisvonatot alkalmaztunk (7. ábra). A vonat mozdonya, illetve vagonjai jól elkülöníthető egységeket képeznek, illetve a mozdonyból kiáradó füst a vonat haladási irányát is jelzi. A feladatok változatossá tétele során ebben az esetben is a hátteret módosítottuk. A szubtesztben való előrehaladás során maga a vonat is előrébb halad, melyet a mögötte látható dombok mozgása szimbolizál. 


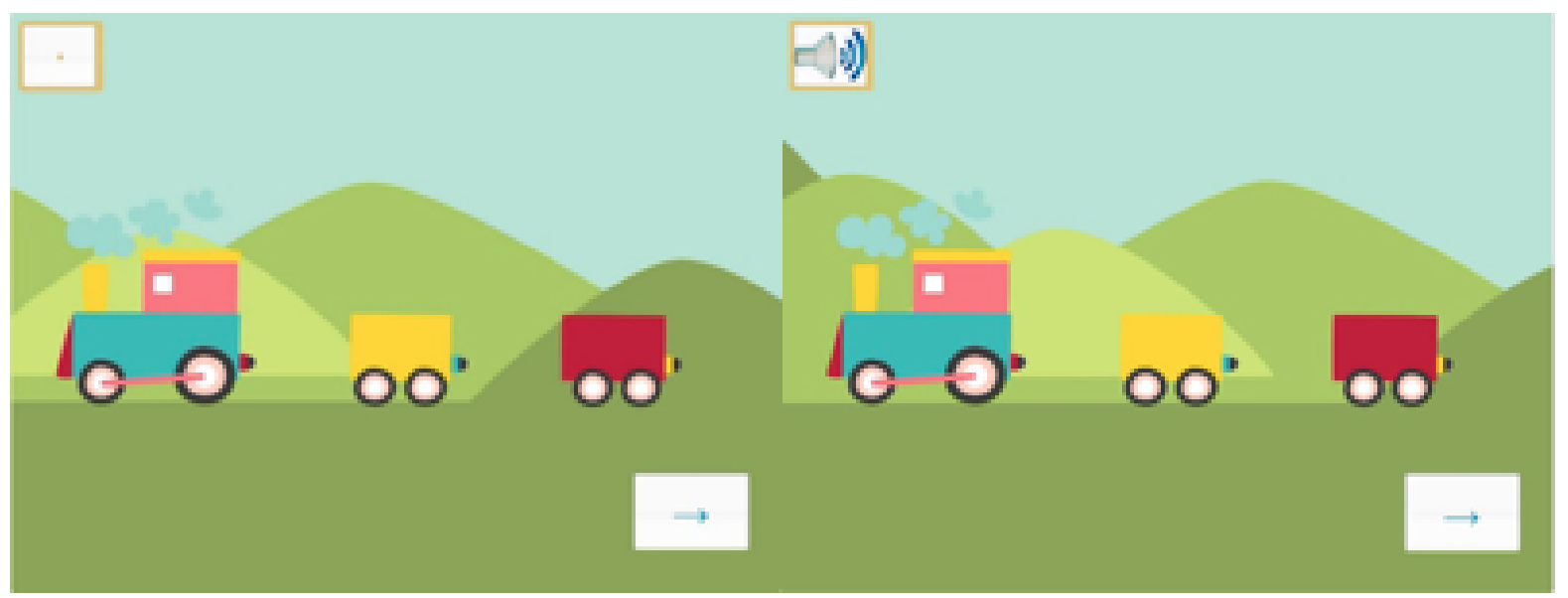

\section{2. ábra}

A fonémaazonositás a hivóhang helyének meghatározásával típusú feladat megjelenitési formája

A szókezdő hangok azonosítását kérő feladat esetében képekkel dolgozunk (8. ábra). Ezek a képek a feladat során megnevezésre/azonosításra kerülnek. Az azonosításhoz segítségül szolgál egy piros, a kép nevének elhangzása során látható keret, mely tulajdonképpen mintegy helyettesíti a szemtől szembeni mérések során történő, ujjal történő rámutatást. Ez a piros keret az adott kép nevének elhangzása esetén körbeöleli a szót szimbolizáló képet, majd eltünik, a következő kép megnevezése során pedig akörül tünik fel, majd ismételten eltűnik. A feladat megjelenítéséből adódóan a folyamat egy adott feladaton belül háromszor ismétlődik.

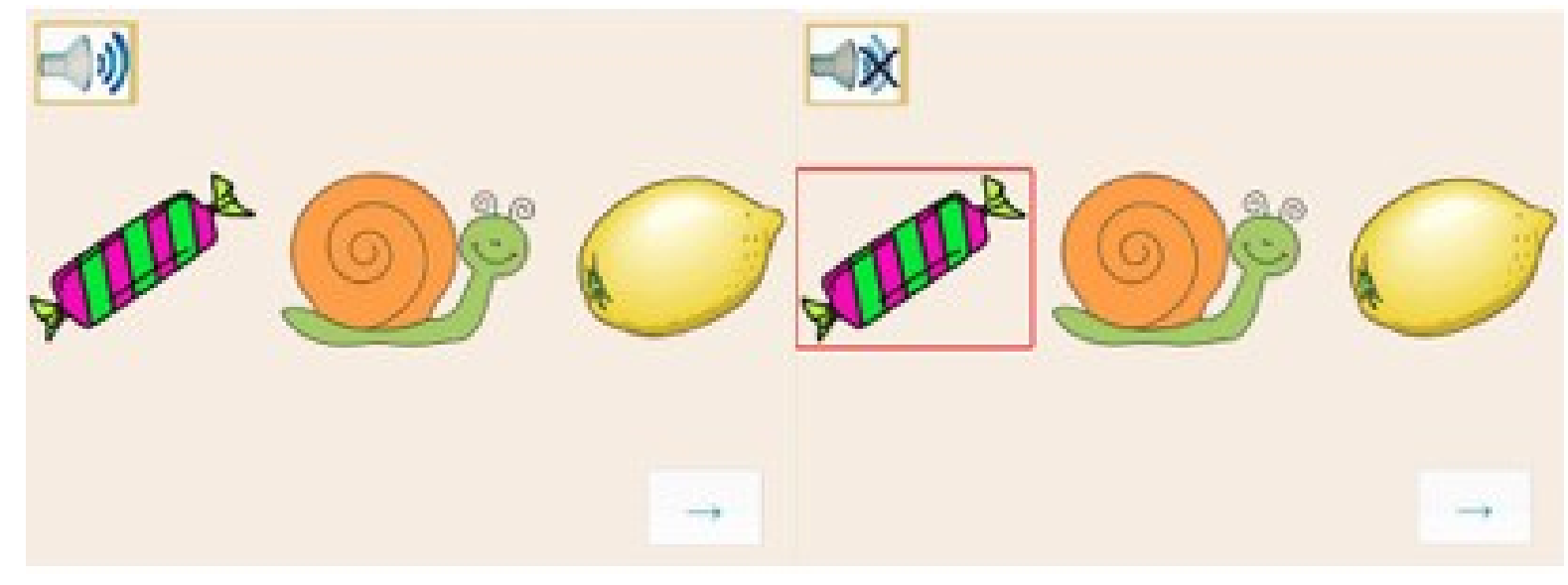

8. ábra

A szókezdö hang azonositását kérö feladat megjelenítési formája

A műveleti szintet képviselő feladatok megjelenítési formái között, a nyelvi szintek tekintetében, nem mutatkozik különbség. A szintézis és törlés feladatok esetében három kép 
közül kattintással választja ki a tanuló az általa helyesnek vélt választ (9. ábra). Természetesen a hívószók tekintetében a képek, valamint a háttérszín és a képek körüli keret színe változik.

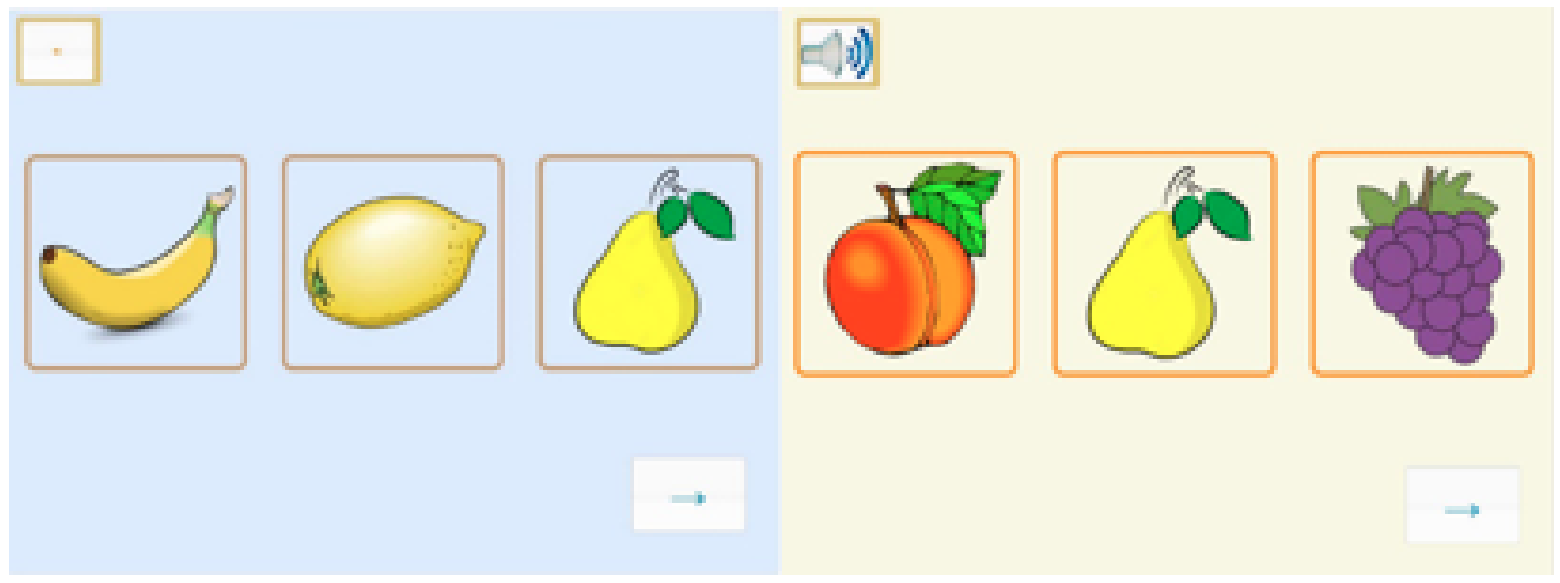

\section{9. ábra}

A szótag-és a fonémaszintézist, valamint a szótag- és a fonématörlést kérö feladatok megjelenitési formája

A szegmentálást kérő feladatoknak két változata is elkészült. Az első változatban a vonszolás müveletével kellett a domino kockáira emlékeztető pöttyök közül kiválasztani a legmegfelelöbbet. A szótagszegmentálás és a fonémaszegmentálás feladatok között minimális megjelenítésbeli különbség tapasztalható (10. ábra), viszont ez a különbség a válaszadás folyamatát (utasítás meghallgatása, bábu megfelelő célmezőbe való vonszolása) nem érinti. A feladat során, hasonlóan a fonémaazonosítást kérő feladat esetében (6. ábra), szintén a háttérrel, azaz jelen esetben a fü mozgásával jeleztük a feladatok közti haladást, szimbolizálva a kukac haladását. 


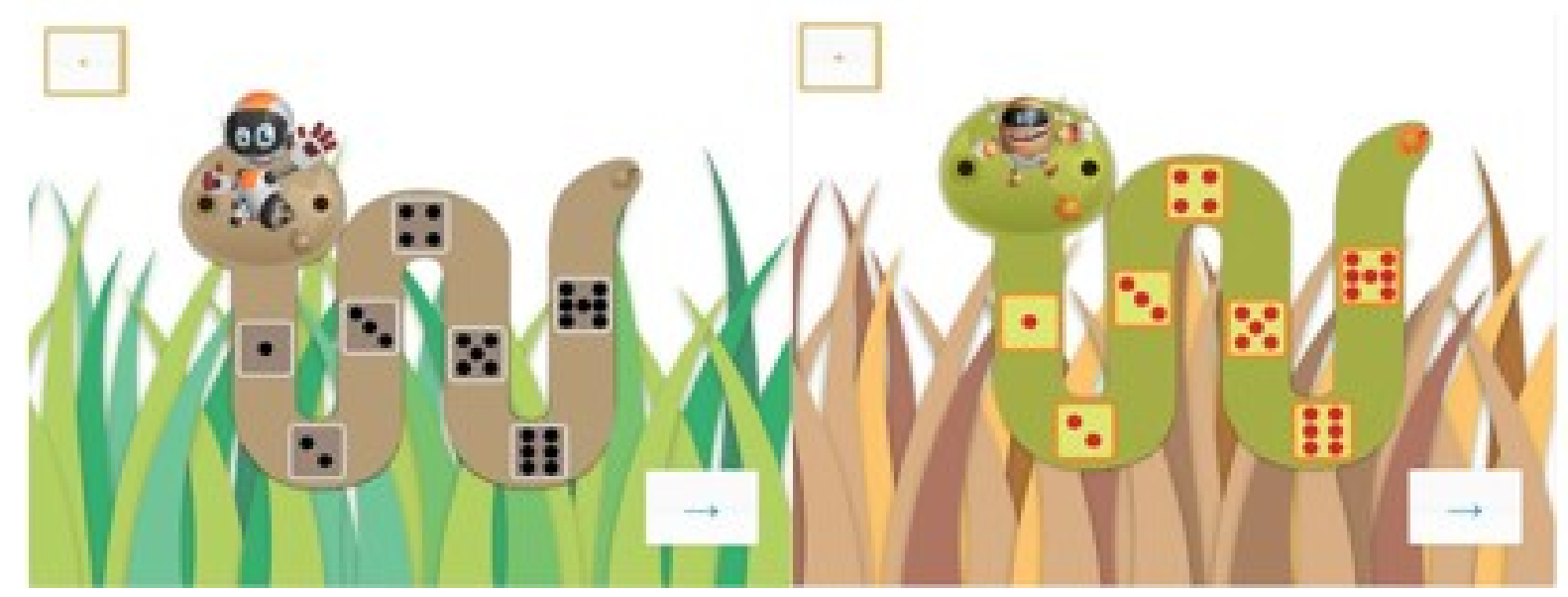

\section{0. ábra \\ A szótag- és a fonémaszegmentálás feladatok megjelenitési formája}

A feladat megjelenítési formáját a 2016-os mérésre tovább egyszerüsítettük, ezáltal a fonématudatosságot vizsgáló tesztben egységesen csak a kattintás/tappelés müvelete jelent meg. Az eredeti és a módosított feladattípust a 11. ábra jeleníti meg. A virágszirmokra történő kattintás sorrendje a feladat értékelésének szempontjából nem releváns, ahogy az sem, hogy a gyermek, sorban, az egymás melletti szirmokra kattint-e vagy sem. A 2016-os tesztelés során ez a feladattípust már csak a fonémaszegmentálást kérő itemekre készítettük el, hiszen az említett mérés során szótagszintű feladatok nem jelentek meg.

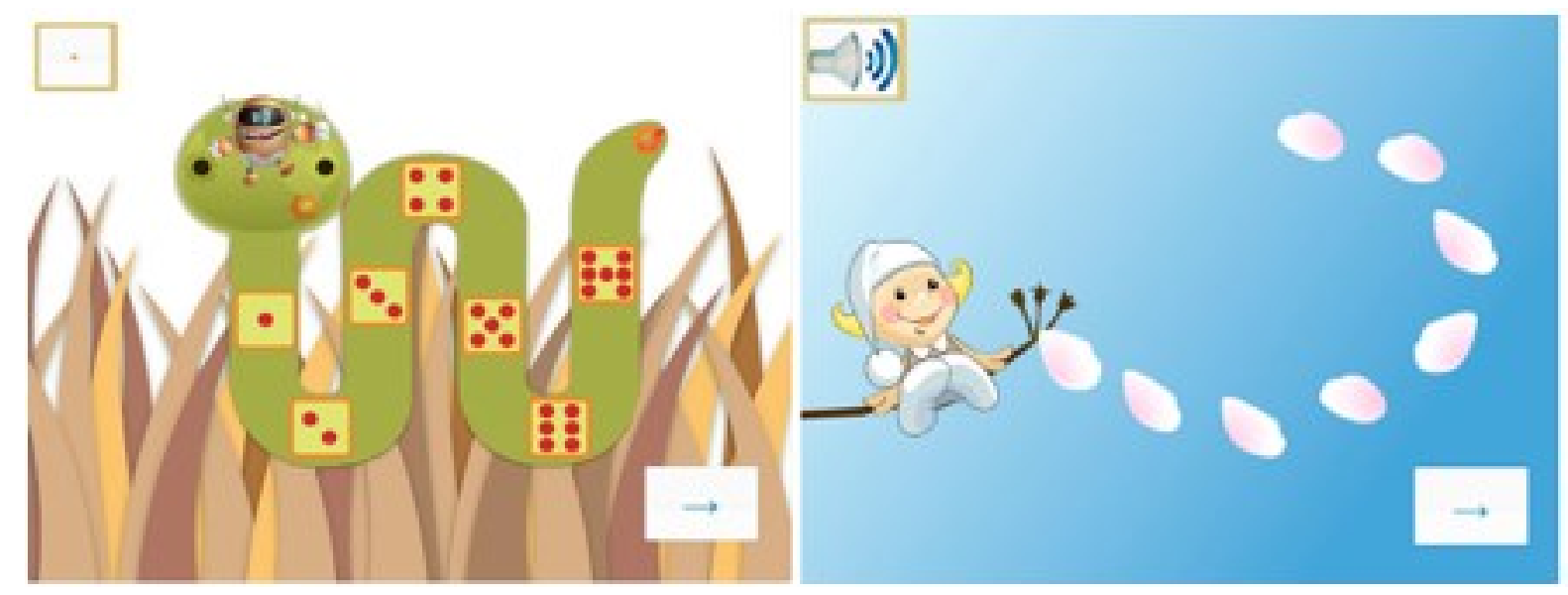

41. ábra

A fonémaszegmentálás feladat eredeti és módositott változatának megjelenitési formája

A bemutatott feladatokat három mérési ponton alkalmaztuk. Az első mérési pont egy 55 itemet tartalmazó, első osztályban rögzített fonológiai tudatosság teszt volt. A teszt 15 iteme 
szótagszintű feladatokat, 40 iteme pedig fonémaszintü feladatokat tartalmazott. A méröeszközben a fonémaazonosítás és a fonémaazonosítás a hang helyének meghatározásával feladattípusok 10-10, a többi feladattípus (azótagszintézis, -szegmentálás, -törlés és, szókezdő hang azonosítása, fonémaszintézis, -szegmentálás, -törlés) 5-5 itemmel képviseltete magát. Ez az alap mérőeszköz került rögzítésre 2015 őszén általános iskola első osztályos tanulói, és 2016 tavaszán óvoda nagycsoportos, korük szerint iskolaérett gyermekek körében. 2016 őszén a módosított fonémaszegmentálás feladat alkalmazásával (11. ábra), 40 itemen keresztül, fonématudatosságot vizsgáltunk az általános iskola első osztáylos tanulói körében. A tesztek, a vizsgálat módszertanának részletes bemutatását az egyes vizsgálatok eredményeinek bemutatása során tárgyaljuk (5.1., 6.1., 7.1., és 8.1. fejezet).

\section{6. Adatelemzés}

A dolgozat ötödik, hatodik és hetedik fejezetei minden esetben tartalmazzák az adott vizsgálatra vonatkozó módszerek, mérőeszközök, eljárások és eredmények leírását. A két országos vizsgálat esetében a Központi Statisztikai Hivatal (KSH) vonatkozó adatait alkalmazzuk a minta a reprezentativitásának vizsgálatára, majd pontos képet adunk a régiónkénti és megyénkénti eloszlásokról mind az összminta, mind a nemek tekintetében. Az adatok elemzése során a klasszikus és a modern statisztikai módszereket egyaránt alkalmazzuk. A tesztek belső konzisztenciájának megbízhatósági mutatójául a Cronbach- $\alpha$ mutatót használjuk, majd az itemek tesztbeli működésének vizsgálatára elöször az elkülönítés mutató értékeit vesszük alapul, megállapítjuk mely itemek eltávolítása indokolt. Az személy-item térkép megalkotásához a ConQuest program használatával RASCH-modellt rajzoltunk fel az itemek müködésének, és ezáltal a gyermekek képességszintjének jellemzéséhez (Molnár, 2013). Minden esetben vizsgáljuk a teszten belüli korrelációs értékeket, majd a teszt szerkezetének, belső konstruktumának vizsgálatához, és annak felrajzolásához megerősítő faktorelemzést végzünk az $\mathrm{R}$ statisztikai program segítségével. A tanulók teszten elért teljesítményét a leíró statisztikai módszereken túl az eloszlásokkal is jellemezzük. A rendelkezésünkre álló háttéradatok vizsgálatához (vizsgált mintán belüli életkori eloszlás, nem, géphasználat teszttel való kapcsolat) ANOVA elemzést, t-próbát és regressziós elemzéseket alkalmazunk. 


\section{A FONOLÓGIAI TUDATOSSÁG ONLINE FELÜLETRE ADAPTÁLHATÓ RÉSZTESZTJEINEK MÉRÉSI LEHETŐSÉGEI AZ ÁLTALÁNOS ISKOLA ELSŐ OSZTÁLYOS TANULÓINAK KÖRÉBEN}

\subsection{Módszerek}

\section{1. 1. A vizsgálatban szereplő minta bemutatása}

A 2015-ös, első osztályosokat felölelő minta 51 iskola, 71 osztályának, 1301 tanulójából állt. A gyermekek átlagéletkora 6,67 év (szórás=0,59 év). Az adatfelvétel évében, az általános iskola első osztályát megkezdő tanulók, valamint a mintában szereplő tanulók regionális eloszlását az 12. ábra szemlélteti, míg a lány és a fiú tanulók eloszlását az 13. és 14. ábrán ábrázoltuk. A hét régió közül Dél-Dunántúl, Észak-Alföld és Közép-Dunántúl esetében közelíti meg a minta eloszlása az országos eloszlást. Két régióban (Közép-Magyarország és Nyugat-Dunántúl) a minta alul-, míg szintén kettő esetében (Dél-Alföld és Észak-Magyarország) felülreprezentált. A rendelkezésünkre álló adatok alapján a minta regionális eloszlásának nemek szerinti bontását is vizsgálni kívánjuk. A lányok esetében alulreprezentáltnak tekinthető Észak-Alföld, KözépMagyarország és Nyugat-Dunántúl, felülreprezentáltnak Dél-Alföld és Észak-Magyarország. A lány tanulók eloszlása Dél- és Közép-Dunántúl esetében közelíti meg az országos eloszlás mértékét. A fiúk esetében alulreprezentáltnak tekintő Közép-Magyarország és NyugatDunántúl, felülreprezentáltnak Dél-Alföld, Dél-Dunántúl és Észak-Magyarország, míg a maradék két régió esetében (Észak-Alföld és Közép-Dunántúl) a mintában szereplő fiú tanulók eloszlása megközelítette az országos fiú tanulók eloszlásának arányát. $\mathrm{Az}$ illeszkedésvizsgálatok szerint a minta és az országos eloszlások között a régiók tekintetében nem jelentkezik különbség sem a teljes minta $\left(\chi^{2}=42,00 \mathrm{df}=36 \mathrm{p}>0,05\right)$, sem a lányok $\left(\chi^{2}=42,00\right.$ $\mathrm{df}=36 \mathrm{p}>0,05)$, sem a fiúk $\left(\chi^{2}=35,00 \mathrm{df}=30 \mathrm{p}>0,05\right)$ esetében. 


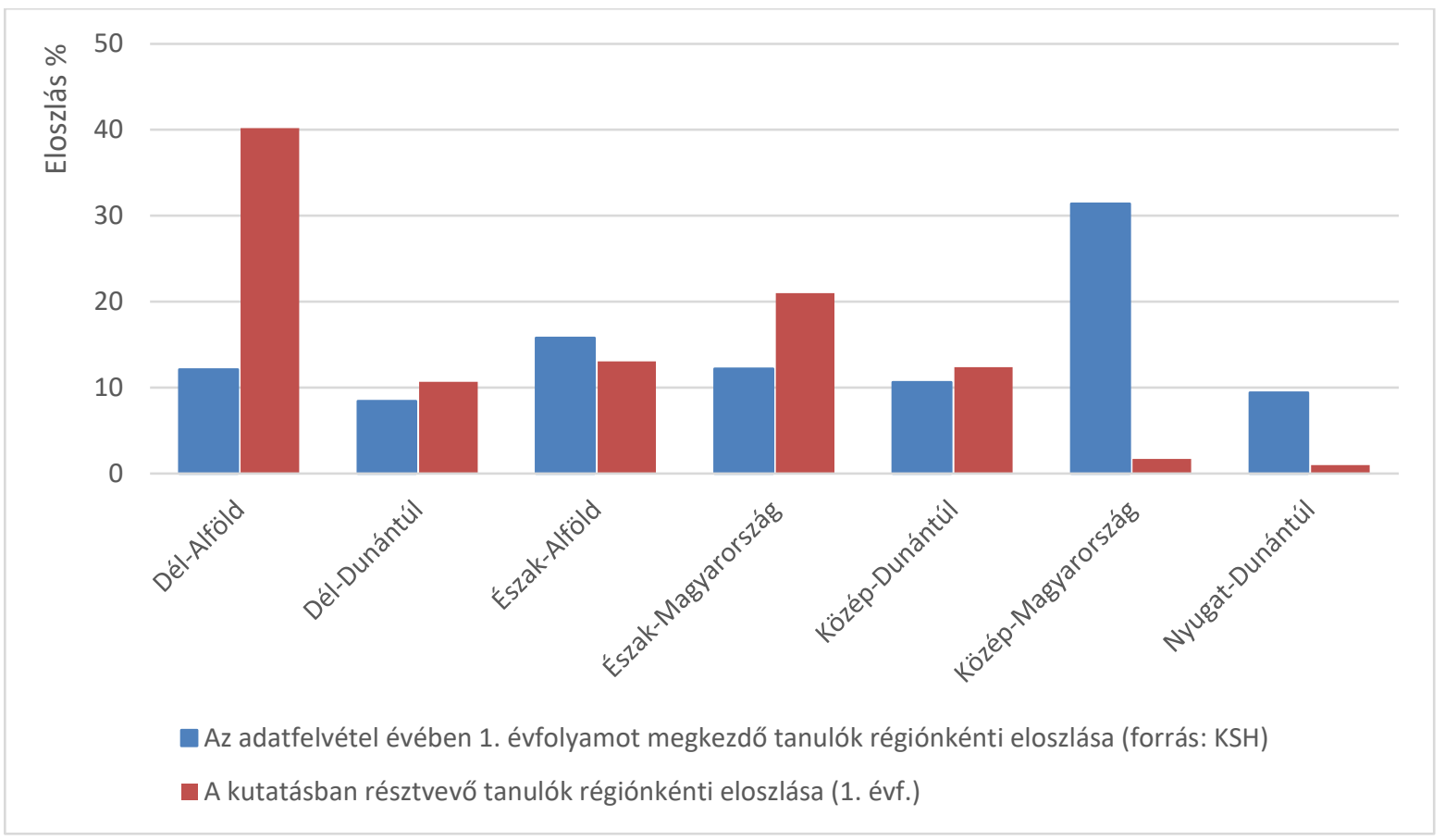

12. ábra

Az adatfelvétel évében (2015) 1. évfolyamot megkezdő tanulók, valamint a vizsgálatainkba bevont minta regionális eloszlása

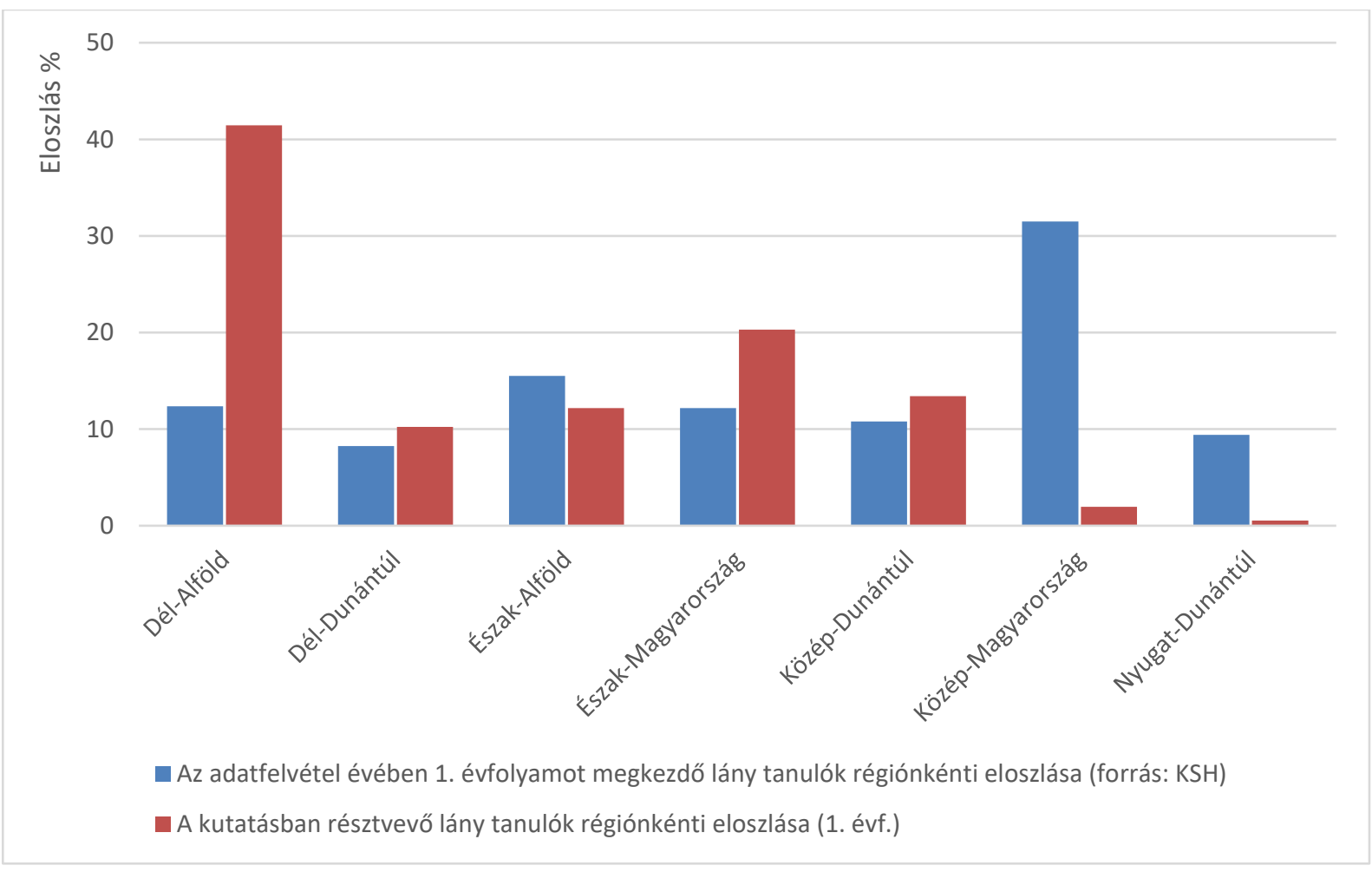

13. ábra

Az adatfelvétel évében (2015) 1. évfolyamot megkezdö lány tanulók, valamint a vizsgálatainkba bevont lány tanulók regionális eloszlása 


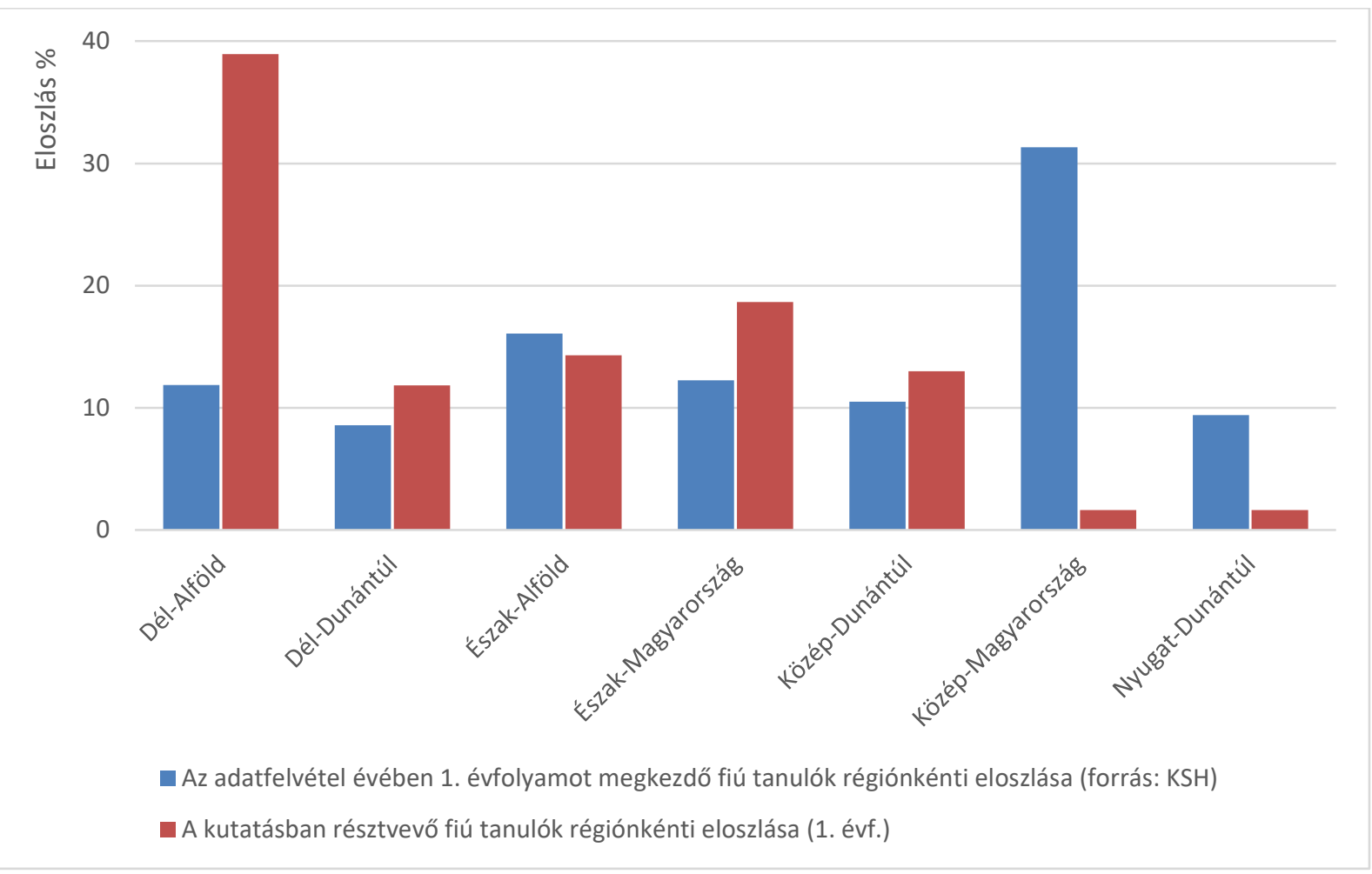

\section{4. ábra}

Az adatfelvétel évében (2015) 1. évfolyamot megkezdö fiú tanulók, valamint a vizsgálatainkba bevont fiú tanulók regionális eloszlása

A megyénkénti eloszlások vizsgálatával árnyaltabb képet kaphatunk a minta eloszlásáról (15. ábra). Mivel a mintánkban Pest megye egyedül Budapesttel képviseltette magát, ezért eltekintettünk a megye feltüntetésétől, és az ábrán Budapestet jelenítettük meg. Az ábráról egyértelműen leolvasható, hogy Budapest alulreprezentáltsága a legerősebb. Szintén alulreprezentált Baranya, Szabolcs-Szatmár-Bereg, Tolna és Zala megye, míg felülreprezentáltnak tekinthető Békés, Borsod-Abaúj-Zemplén, Csongrád, Fejér és Somogy megye. A lányok esetében az alulreprezentált Hajdú-Bihar megye, felülreprezentált BácsKiskun megye (16. ábra). A fiúk esetében a teljes minta megyei eloszlásához képest alulreprezentált Heves és Nógrád megye, felülreprezentált pedig Jász-Nagykun-Szolnok megye (17. ábra). A megyei szintü eloszlások vizsgálata során nem tapasztaltunk szignifikáns különbséget sem a teljes minta $\left(\chi^{2}=195,00 \mathrm{df}=182 \mathrm{p}>0,05\right)$, sem a lányok $\left(\chi^{2}=182,00 \mathrm{df}=169\right.$ $\mathrm{p}>0,05)$, sem a fiúk $\left(\chi^{2}=180,00 \mathrm{df}=168 \mathrm{p}>0,05\right)$ esetében. 


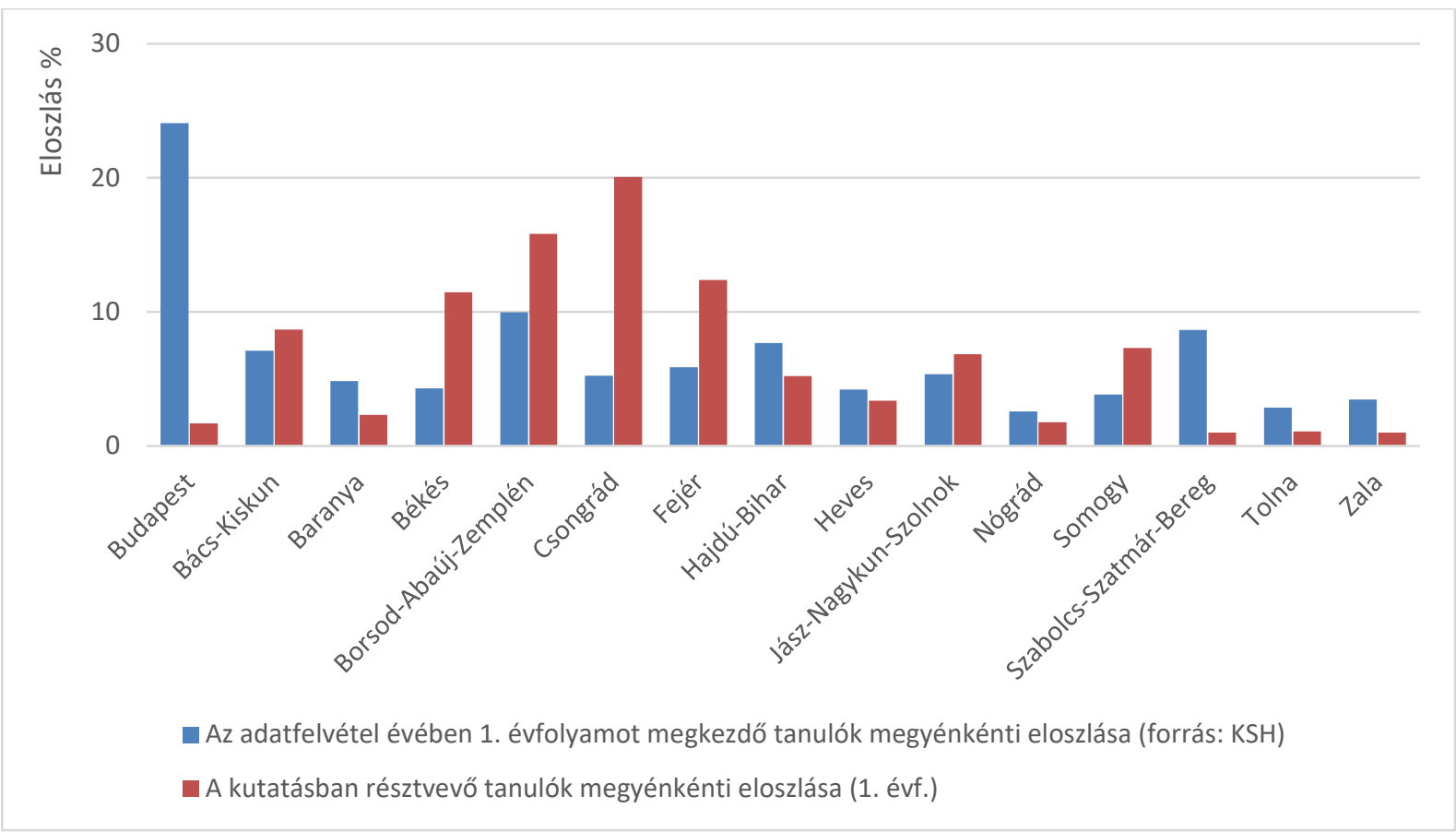

15. ábra

Az adatfelvétel évében (2015) 1. évfolyamot megkezdö tanulók megyénkénti eloszlása

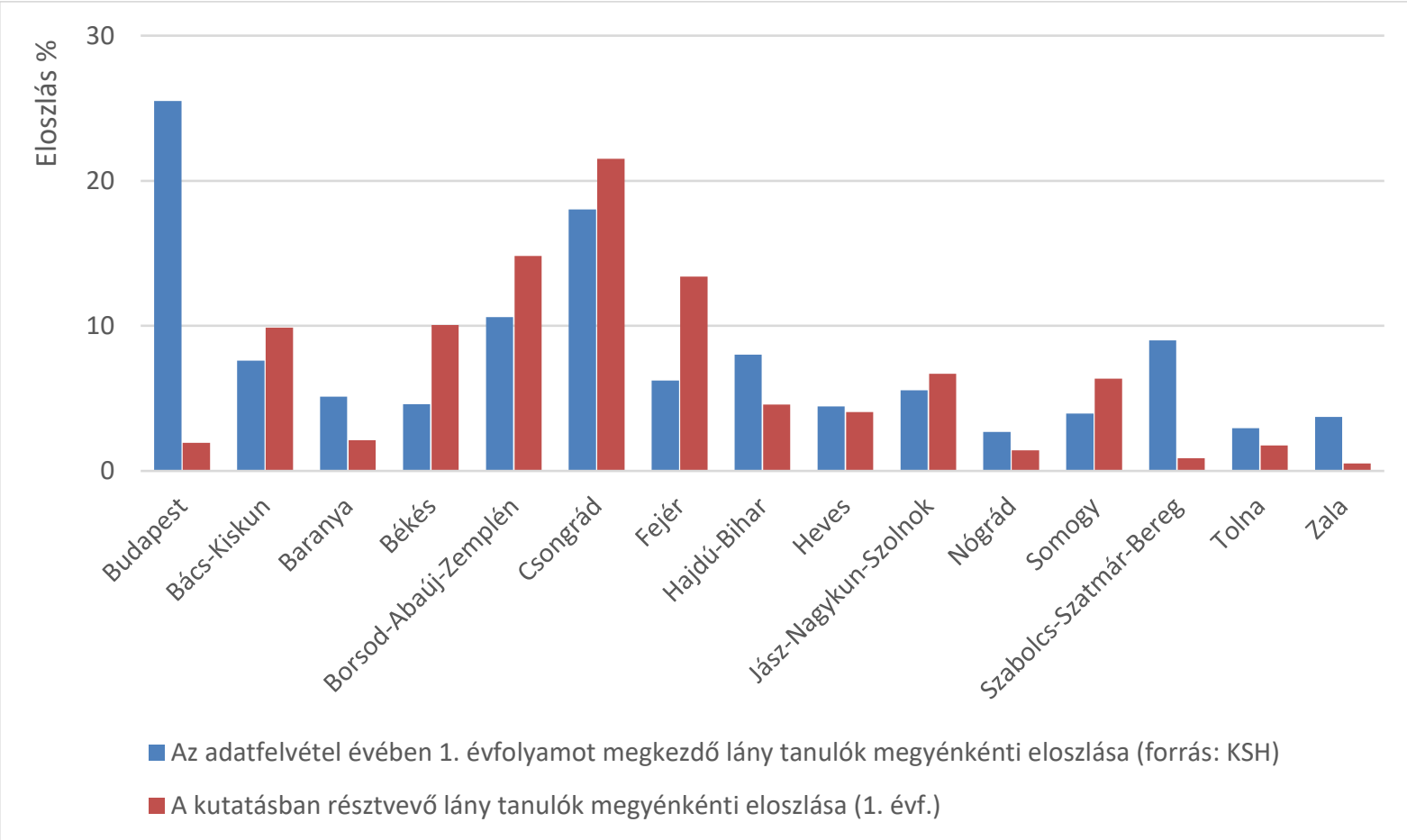

16. ábra

Az adatfelvétel évében (2015) 1. évfolyamot megkezdö lány tanulók, valamint a vizsgálatainkba bevont lány tanulók megyénkénti eloszlása 


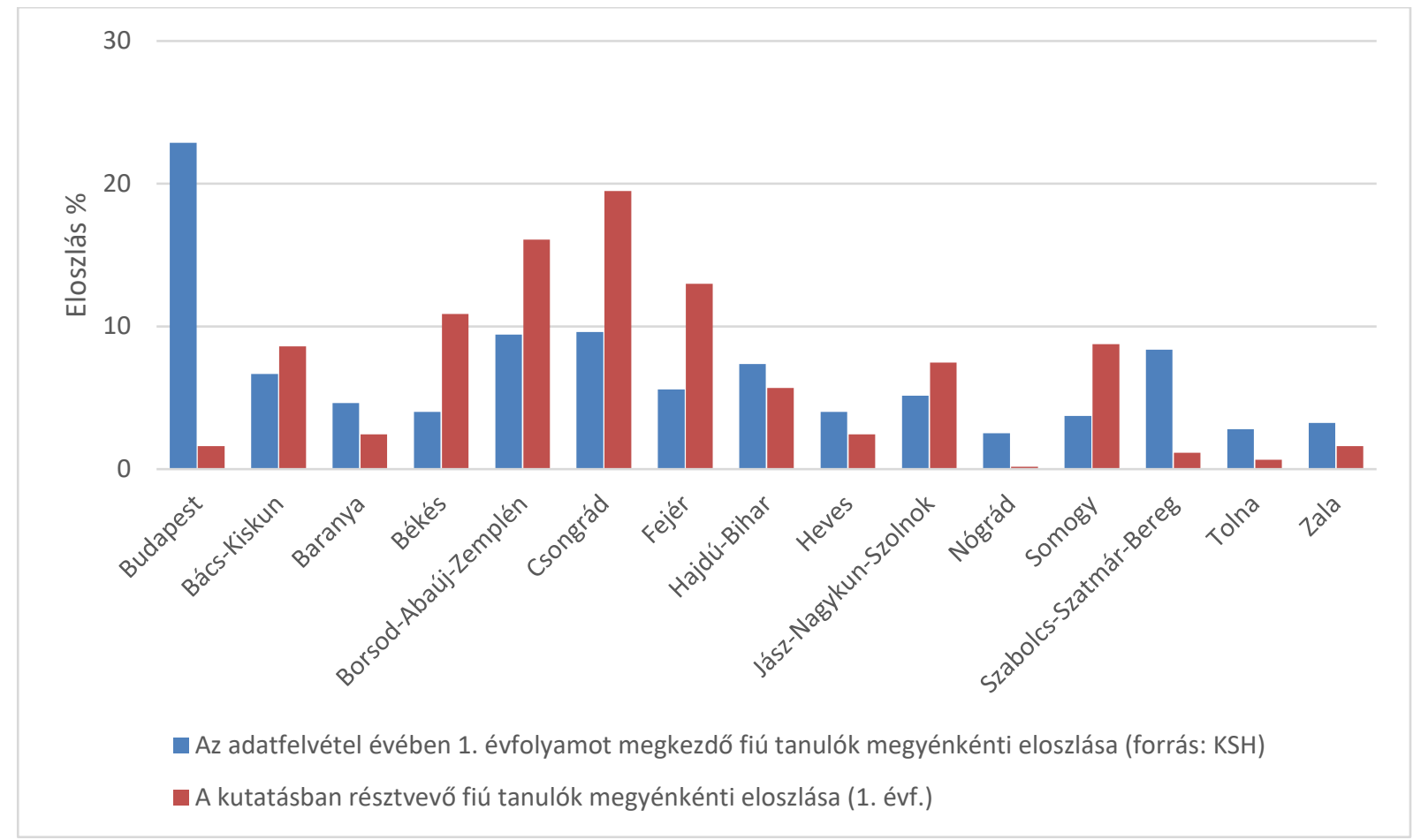

\section{7. ábra}

Az adatfelvétel évében (2015) 1. évfolyamot megkezdö fiú tanulók, valamint a vizsgálatainkba bevont fiú tanulók megyénkénti eloszlása

\section{1. 2. A mérőeszköz}

A mérőeszköz olyan készségek vizsgálatára irányul, amelyek a későbbi olvasásteljesítmény megbízható jóslói, előrejelzői. Jelen teszt két nyelvi szinten (szótag és fonéma szint) keresztül hét feladattípus fejlettségi szintjének megállapítását teszi lehetővé. A kialakított teszt felépítését az 13. táblázat szemlélteti.

13. táblázat. Az online fonológiai tudatosság teszt felépitése

\begin{tabular}{cccc}
\hline Terület & Részterület & Feladattípus & Itemszám \\
\hline Fonológiai & Szótagtudatosság & Szótagszintézis & 5 \\
tudatosság & Szótagszegmentálás & 5 \\
& \multirow{2}{*}{ Fonématudatosság } & Szótagtörlés & 5 \\
& & Fonémaazonosítás & 25 \\
& & Fonémaszintézis & 5 \\
& & Fonémaszegmentálás & 5 \\
& & Fonématörlés & 5 \\
\hline Teljes teszt & & $\mathbf{5 5}$ \\
\hline
\end{tabular}


Az adatfelvétel során a gyermekek elöször szótagtudatosságra, ezt követően fonématudatosságra vonatkozó feladatokat kapnak, biztosítva így számukra a nagyobb nyelvi egység felől a komplexebb, beszédhangokkal végzett müveletek felé haladás folyamatosságát.

A szótagtudatosság mérése során három feladattípus jelenik meg. A szótagszintézis feladatok megoldása során a gyermek szótagokra tagolva hallja a hívószót, majd a hallott inger alapján a hívószót jelölő képre kattint. A helyes válasz tehát a citrom szó tagolt formájának meghallgatása után a citrom képére történő kattintással adható meg (18. ábra). A szótagszegmentálás feladatok során a gyermek szótagokra bontja a hallott szót, majd arra a mezőre húzza a bábuját, amelyikben annyi pöttyöt lát, ahány szótagra bontotta a hívószót (19. ábra). A szótagtörlés feladatok során a gyermek egy szót hall, amelynek első vagy utolsó szótagjának elhagyásával, egy, a képernyőn látható kép nevét kapja. A feladat megoldása a képre történő kattintással adható meg. A példafeladatban a rádió első tapsának, szótagjának elhagyásával a dió szó keletkezik, így a helyes válasz a diót ábrázoló képre történő kattintással adható meg (20. ábra).

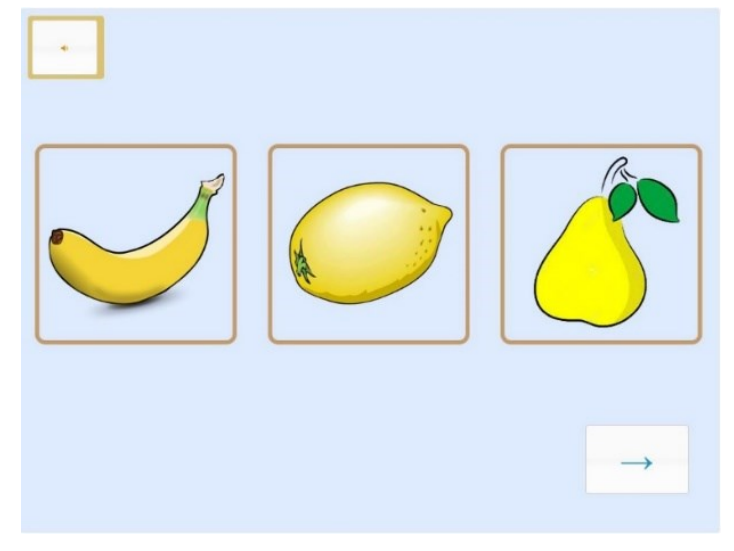

18. ábra

Példafeladat a szótagszintézis feladat megjelenitési formájára

[Egy szót fogok neked mondani, de jól figyelj, mert lassan, tagoltan mondom. Melyik kép neve lehet ez? Kattints rá! citrom]

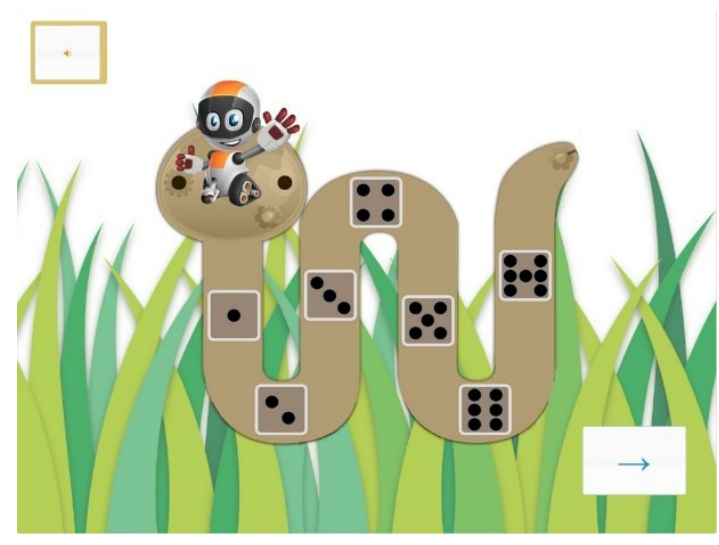

19. ábra

Példafeladat a szótagszegmentálás feladat megjelenitési formájára

[A hallott utasitás: Társasozni fogunk. A bábud a kiskukac fején áll. Húzd arra a mezöre a bábud, amennyit erre a szóra tapsolnál: alma] 


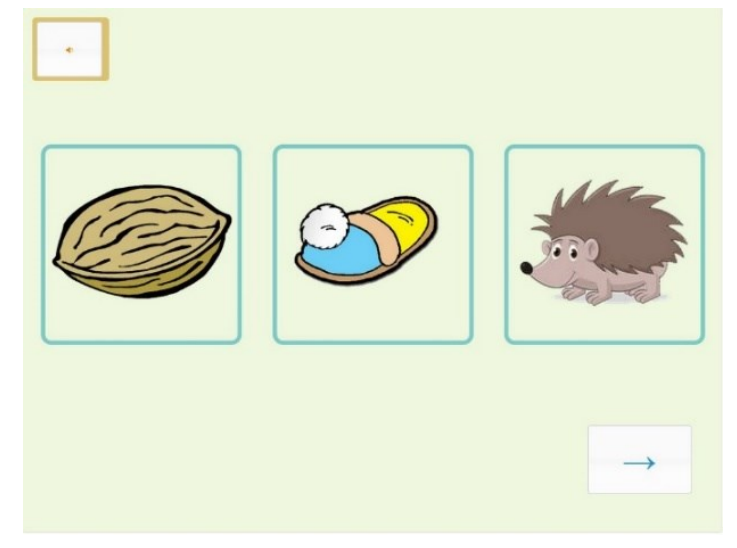

\section{0. ábra \\ Példafeladat a szótagtörlés feladat megjelenitési formájára \\ [Egy szót fogsz hallani. Tapsold el magadban a szót, majd mondd ki az elsö taps nélkül. Melyik kép jelöli az új szót? Kattints rá! rádió]}

A fonématudatosság mérése során négy feladattípus jelenik meg. A fonémaazonosítás feladatok esetében a gyermekeknek hívóhangról meg kell állapítaniuk, hogy hallották-e azt a szóban, vagy sem. Ha válaszuk igenlő, akkor a zöld pipára kattintanak, ha nemleges, akkor a piros x-re (21. ábra). A fonémaazonosítás feladat komplexitását növeli, hogy a gyermektől a hang helyének meghatározását is kérjük. Ebben a feladatban a kisvonat elejére (mozdonyra), vagy közepére illetve végére (első vagy második vagonra) történő kattintással dönt, hogy a feladatok során szókezdő, szóbelseji vagy szóvégi pozícióban hallotta az adott hangot. A példafeladat a $\mathrm{v}$ hang szókezdő pozíciójának megállapítását kéri a tanulótól, így a helyes válasz a mozdonyra történő kattintással adható meg (22. ábra). A szókezdő hangok azonosítása során a gyermek számára megnevezzük a képeket, majd kattintással dönt, hogy melyik két kép neve kezdődött ugyanazzal a hanggal. A mintafeladatban megfigyelhetö, hogy a szókezdő hangok azonos fonológiai helyzetben szerepelnek, tehát mindhárom esetben magánhangzó követi őket. A feladat megoldása a banán és a barack képére történő kattintással adható meg (23. ábra). 


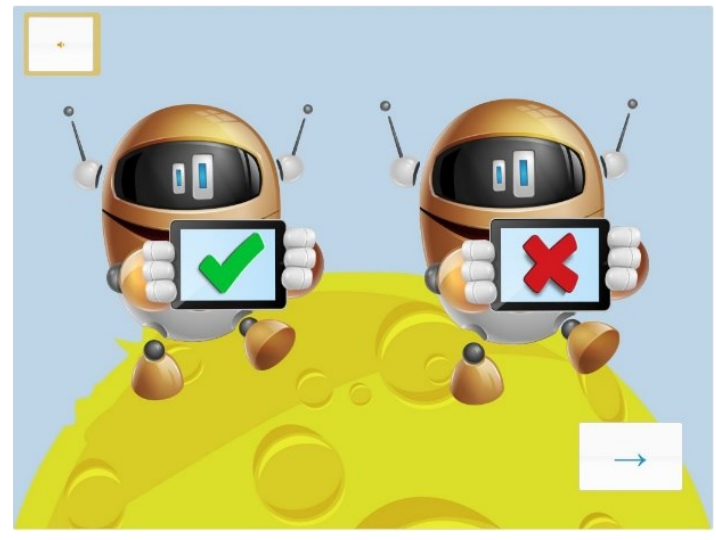

215. ábra

Példafeladat a fonémaazonositás feladat megjelenitési formájára

[Hallod-e a hangot a szóban? Ha igen, kattints a pipára, ha nem, kattints az x-re! kulcs]

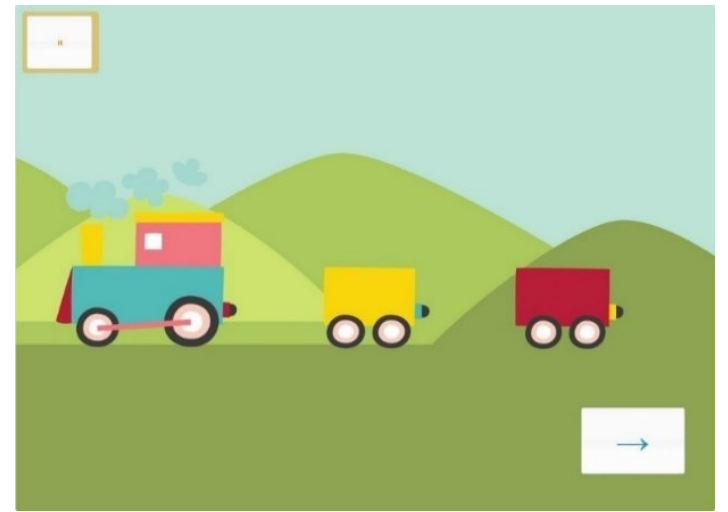

6. ábra

Példafeladat a fonémaazonositás a hivóhang helyének meghatározásával típusú feladat megjelenitési formájára [Hol hallod a hangot a szóban? A szó elején, közepén vagy végén? Kattints a kisvonat elejére, közepére vagy végére! v vakáció]

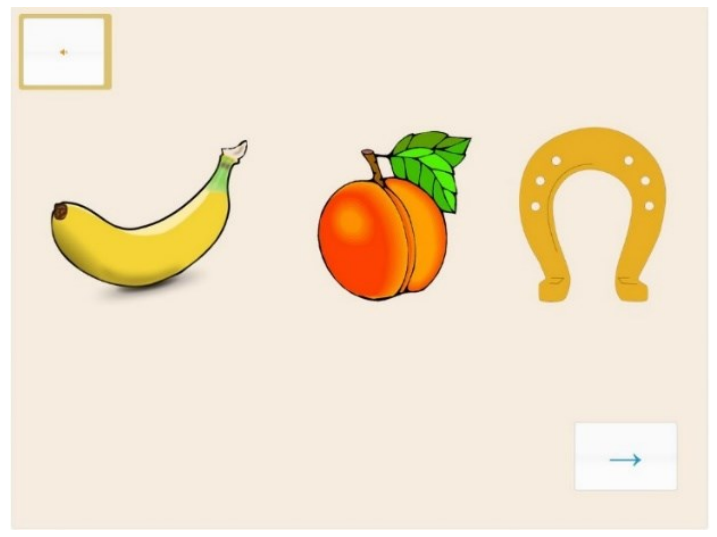

23. ábra

Példafeladat a szókezdö hangok azonositását vizsgáló feladat megjelenitési formájára [Ez egy banán, ez egy barack, ez pedig egy patkó. Melyik kettö kezdödik ugyanúgy? Kattints rájuk!]

A mérőeszköz további részében a fonémaszintű szintézis, szegmentálás, és törlési műveletek jelennek meg, megjelenésük alapja, illetve a válaszadás módja szinte azonosságot mutat a szótagszintü feladattípusokéval. A fonémaszintézis feladat során a gyermek hangjaira bontva hallja a képernyőn szereplö egyik kép nevét, majd kattintással dönt, melyiket hallotta (24. ábra). A példafeladat a csikó képére történő kattintással válaszolható meg. A fonémaszegmentálás 
részben a gyermek a társasjáték bábuját húzza arra a mezőre, amelyen annyi pont van ahány hangot hallott a szóban (25. ábra). A mintafeladat a bábu második, azaz két pöttyöt tartalmazó mezőre való húzásával válaszolható meg. A fonématörlés részteszt egy-egy szóeleji vagy szóvégi hang elhagyását kéri a tanulótól. A képernyőn a tanulónak csupán a keletkezett szót szimbolizáló képre kell kattintania (26. ábra), a példafeladat a szóvégi d hang elhagyásával, a középső képre történő kattintással válaszolható meg.
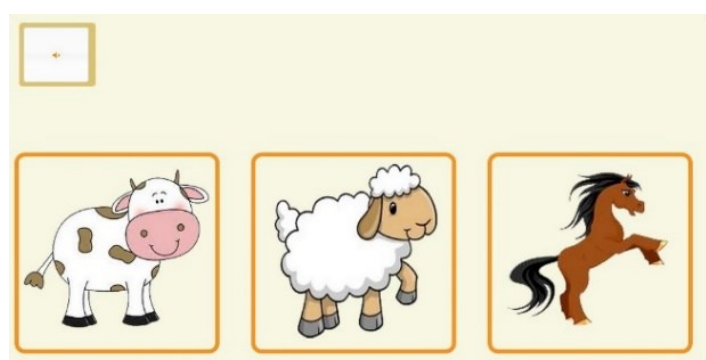

24. ábra

Példafeladat a fonémaszintézis feladat megjelenitési formájára [Egy szót fogok neked mondani, de jól figyelj, mert lassan, hangokra bontva mondom.

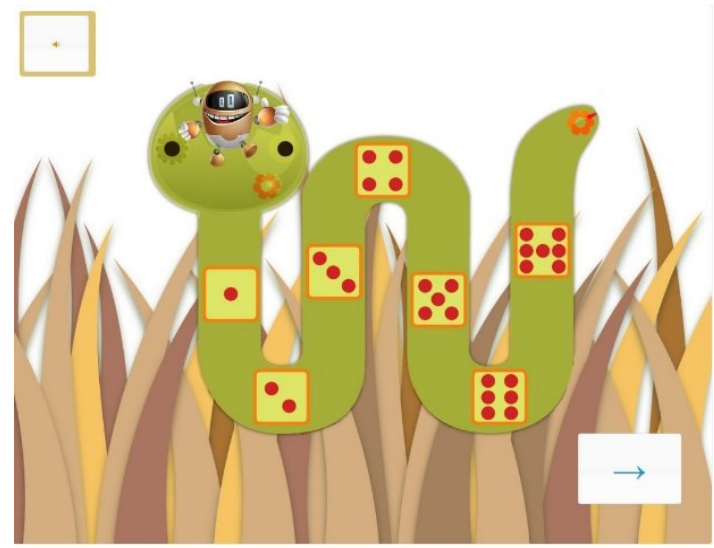

\section{5. ábra}

Példafeladat a fonémaszegmentálás feladat megjelenitési formájára

[Társasjátékot fogunk játszani. Szavakat fogsz hallani. Lépj annyit Robi robottal, ahány hangot hallasz a szóban! fa]

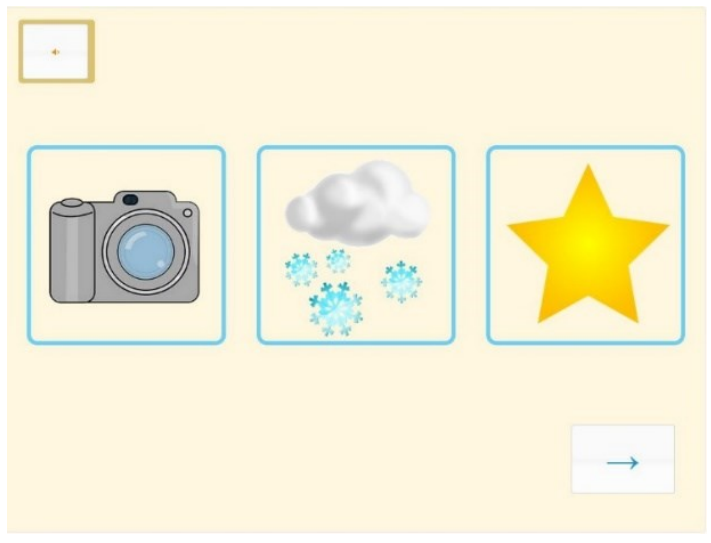

7. ábra

Példafeladat a fonématörlés feladat megjelenitési formájára 
[Egy szót fogsz hallani. Mondd ki magadban a szót az utolsó hangja nélkül. Melyik kép jelöli az általad kimondott szót? Kattints rá! hód]

\section{1.3. Eljárás}

Az általános iskolai tesztfelvétel megkezdése előtt az iskolák számára mérési útmutatót küldtünk, melyben ismertettük a mérés tárgyát, valamint a tesztek rögzítésére és a mérések lebonyolításához szükséges instrukciókat (2. melléklet). Az iskola a tanulók köznevelési információs rendszeren (KIR) keresztül generált mérési azonosítóját alkalmazta belépési azonosítóként, ezáltal biztosítva a mérésben résztvevő tanulók anonimitását. Mivel az elsős korosztály még magabiztosan írni és/vagy olvasni nem tud, ezért kértük a pedagógusokat, hogy a tanulók mérési azonosítóját a mérés megkezdése előtt a kijelölt helyre gépeljék be, ezáltal is gördülékenyebbé téve a tesztelés menetét. Jelen tesztet az iskolakészültségi mérőeszközcsomag második tesztjeként, 45 perces tanóra keretein belül oldották meg a tanulók. A tesztet megelőzte a géphasználat teszt, melynek kitöltésével a tanulók gyakorolhatták a kéz-egér együttmozgásának törvényszerüségét, illetve játékos feladatokon keresztül megismerkedhettek a tesztre jellemző itemtípusokkal, gyakorolhatták az egy vagy több helyre, képre való kattintást, illetve az itemek húzását, vonszolását (3. melléklet).

\section{2. Eredmények}

\section{2. 1. A mérőeszköz megbízhatóságának vizsgálata}

A fonológiai tudatosság több résztesztjét lefedő teszt megbízhatósági mutatóit a 14 . táblázat foglalja össze. Bár a teljes teszt megbízhatósága magas (Cronbach- $\alpha=0,89$ ), mégis, a képesség által lefedett nyelvi egységek és müveletek szerinti elkülönülés miatt, érdemes megvizsgálnunk a résztesztek megbízhatósági mutatóit. Alacsony megbízhatósági mutatóval rendelkezik az 5 itemes szótagtörlés részteszt, és a 10 itemes fonémaazonosítás részteszt. A feladatokat a felismerni kívánt nyelvi egység mérete (szótag és fonéma), valamint a müveleti szintek szerint (szintézis, szegmentálás, törlés, azonosítás) elkülönítés szerint is vizsgáltuk. A nyelvi egység mérete szerinti tagolódás alapján a fonéma egység rendelkezik magasabb, a szótag nyelvi egység alacsonyabb mutatókkal, míg a müveletek szerinti tagolódás esetében a Cronbach- $\alpha$ értékek alapján csökkenő sorrendben az azonosítás, szintézis, szegmentálás és törlés területek következnek. Mindenképp megjegyzendő, hogy mindkét tagolás szerint a legmagasabb értékkel rendelkező egységek képviseltetik magukat a legnagyobb itemszámmal. 
A tesztbe összesen 1301 gyermek lépett be, melyből a teljes tesztre vonatkozóan 1291 érvényes adat érkezett.

14. táblázat. A fonológiai tudatosság teljes tesztjének és résztesztjeinek reliabilitás mutatói (Cronbach- $\alpha$ )

\begin{tabular}{lccc}
\hline \multicolumn{1}{c}{ A teszt megnevezése } & $\begin{array}{c}\text { Itemek } \\
\text { száma }\end{array}$ & Cronbach- $\alpha$ & N \\
\hline Szótagszintézis & 5 & 0,79 & 1301 \\
Szótagszegmentálás & 5 & 0,67 & 1300 \\
Szótagtörlés & 5 & 0,43 & 1300 \\
Fonémaazonosítás & 10 & 0,55 & 1300 \\
Fonémaazonosítás a hívóhang & 10 & 0,78 & 1298 \\
helyének meghatározásával & 5 & 0,75 & 1297 \\
Fonémaszegmentálás & 5 & 0,74 & 1295 \\
Szókezdő hang azonosítása & 5 & 0,72 & 1295 \\
Fonémaszintézis & 5 & 0,66 & 1293 \\
Fonématörlés & 25 & 0,84 & 1295 \\
\hline Azonosítás & 10 & 0,74 & 1294 \\
Szintézis & 10 & 0,71 & 1297 \\
Szegmentálás & 10 & 0,64 & 1293 \\
Törlés & 15 & 0,72 & 1299 \\
\hline Szótag szintü feladatok & 40 & 0,88 & 1292 \\
Fonéma szintű feladatok & $\mathbf{5 5}$ & $\mathbf{0 , 8 9}$ & $\mathbf{1 2 9 1}$ \\
\hline Teljes teszt & & & \\
\hline
\end{tabular}

Mivel a résztesztek reliabilitásmutatói közti különbség jelentős, ezért indokoltnak találtuk az itemek elkülönítés mutatóinak vizsgálatát (27. ábra). A kapott értékek alapján 7 item rendelkezik 0,3 alatti korrelációs értékkel. Ezen itemek eltávolítása bár az összteszt reliabilitását lényegesen nem, de a résztesztek megbízhatóságát, a szótagtörlés részteszt kivételével, jelentősen növelte. A tesztben szereplő további 48 item korrelációja eléri vagy meghaladja a 0,3-as teszt-item korrelációs értéket. A továbbiakban ezen 48 itemet tekintjük a teszt szerves részének. Az elkülönítés mutatók figyelembe vételével módosított tesztet, valamint a teszt és a résztesztek reliabilitás mutatóit az 15. táblázat tartalmazza. Az itemek közti korrelációs értékeket az 4. melléklet tartalmazza. Az átlagos tesztidő 19,41 perc (szórás=5,91), mely megfelel az előzetes elvárásoknak, egy első osztályos tanuló számára átlagosan fél tanóra alatt teljesíthető. 


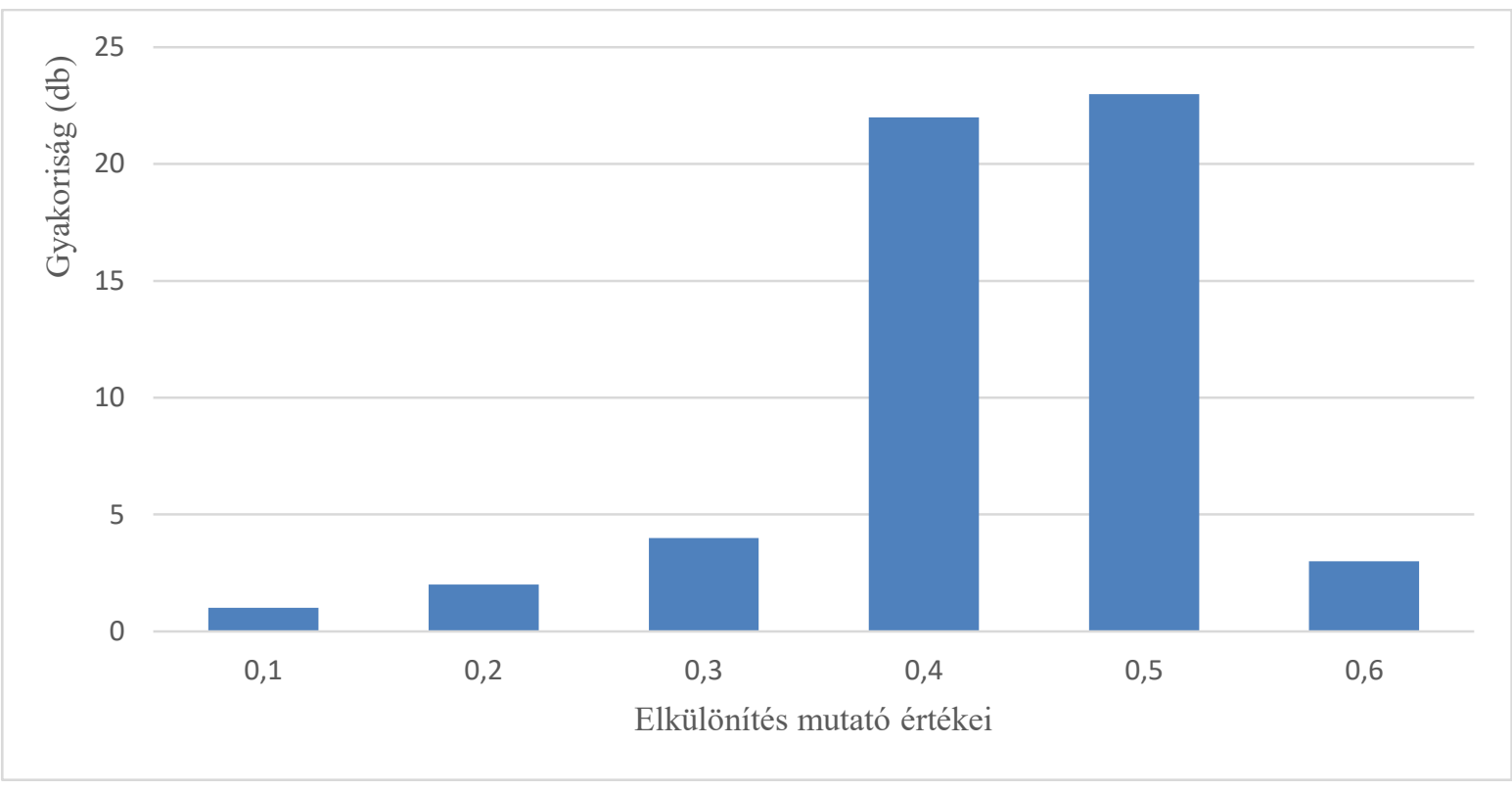

27 ábra

Az itemek elkülönités mutatóinak eloszlási gyakorisága

15. táblázat. Az elkülönités mutatók figyelembe vételével módositott teszt felépitése, a teljes teszt és a résztesztek reliabilitás mutatói (Cronbach- $\alpha$ )

\begin{tabular}{cccc}
\hline A teszt megnevezése & $\begin{array}{c}\text { Itemek } \\
\text { száma }\end{array}$ & Cronbach- $\alpha$ & $\mathrm{N}$ \\
\hline Szótagszintézis & 5 & 0,79 & 1301 \\
Szótagszegmentálás & 5 & 0,67 & 1300 \\
Szótagtörlés & 2 & 0,36 & 1300 \\
Fonémaazonosítás & 7 & 0,63 & 1300 \\
Fonémaazonosítás a hívóhang & 10 & 0,78 & 1298 \\
helyének meghatározásával & 4 & 0,76 & 1297 \\
Fonémaszegmentálás & 5 & 0,74 & 1295 \\
Szókezdő hang azonosítása & 5 & 0,72 & 1295 \\
Fonémaszintézis & 5 & 0,66 & 1293 \\
Fonématörlés & 22 & 0,85 & 1295 \\
Azonosítás & 10 & 0,74 & 1294 \\
Szintézis & 9 & 0,70 & 1297 \\
Szegmentálás & 7 & 0,67 & 1293 \\
Törlés & 12 & 0,75 & 1299 \\
\hline Szótag szintű feladatok & 36 & 0,89 & 1292 \\
\hline Fonéma szintü feladatok & $\mathbf{4 8}$ & $\mathbf{0 , 9 0}$ & $\mathbf{1 2 9 1}$ \\
\hline Teljes teszt & & & \\
\hline
\end{tabular}

\section{2. 2. A feladatok nehézségének és a tanulók képességszintjének feltárása}

Az itemek müködéséröl további információt nyújthat a valószínüségi tesztelmélet alkalmazása (Molnár, 2013). Az EAP/PV reliabilitás mutató értéke 0,89. Az eredmények 
alapján készült személy-item térkép (28. ábra) azt mutatja, hogy az itemek a képességskála széles spektrumát lefedik, találhatunk nehéz, és könnyü itemet egyaránt. Az ábra bal oldalán lévő skála a feladatok nehézségét, míg jobb oldala a tanulók képességszintjét jelzi. Az ábra bal oldalán lévő minden x 8.4 tanulót reprezentál. Az ábra jobb oldalán lévő számok az teszt itemeit jelölik. Az itemek könyebb áttekinthetőségét színekkel segítettük. A fonémaszintű feladatokat a színpaletta hideg, míg a szótagszintü feladatokat a meleg árnyalatok jelzik. Így fonémaazonosítást kék (1-17 és 22-26), a fonémaszegmentálást türkiz (18-21), a fonématörlést sötétzöld (32-36), a fonémaszintézist szürke (27-31), míg a szótagszegmentálást arany (42-46), a szótagszintézist narancssárga (37-41) és a szótagtörlést halványsárga színekkel (47 és 48) jelenítettük meg.

Az itemek a képességkála széles tartományát lefedik, -2,016 és 1,910 itemnehézségi szint közt oszlanak meg. Az itemek eloszlásából látszik, hogy a feladatok nehézségét nem a nyelvi egység nagysága határozta meg, hiszen mind a fonémaszinttel, mind a szótagszinttel kapcsolatos itemek szétszóródnak a képességskálán. A szegmentálás műveletét magába foglaló feladatok (fonámaszinten a 18, 19, 20, 21, 22, szótagszinten a 42, 43, 44, 45, 46-os számmal jelöltek) az 1,381 és 1,910 logitértékek között helyezkednek el, ezzel kijelenthető, hogy ezen feladatok a gyermekek számára nehéznek tekinthetők. Közöttük csupán három, az azonosítás müveletét megkövetelő feladat $(10,4,11)$. kapott helyet A -0,091 és 0,568 képességszintek között kizárólag azonosítási feladatok szerepelnek. Ezen intervallum alatt már keverednek a törlés és szintézis müveletét kérő feladatok, viszont a -1,427-es logitérték alatt már csak szintézist kérő feladatok szerepelnek. A -1,427 és 0,285 közötti tartományban helyet kap egy, fonémaazonosítást kérö feladat is (1-es számmal jelölt szám). Bár a képességszintek szerint kategorikusan nem különíthetők el az egyes itemek, de az a tendencia rajzolódik ki, mely szerint az itemnehézségi skála alapján nehéz, összetett feladatnak számított a szegmentálást kérő feladat, majd az egyre könnyebbek felé haladva következtek az azonosítást, törlést és szintézist kérő itemtípusok. A tanulók teljesítményét leginkább a 19 és 21-es számú feladatok differenciálták, melyek egy-egy fonémaszegmentálási feladatot jelöltek. Az itemekA tanulók teljesítményét egy szótagszintézis feladat (41) nem differenciálta, hiszen azt minden tanuló helyesen oldotta meg. 
4

3

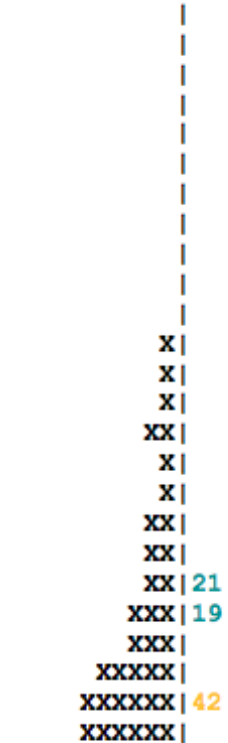

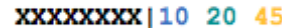

28. ábra

Az elsö osztályos fonológiai tudatosság teszt személy-item térképe.

A fonémaszintü feladatokat a szinpaletta hideg, míg a szótagszintü feladatokat a paletta meleg árnyalatai jelzik. Így fonémaazonositást kék, a fonémaszegmentálást türkiz, a fonématörlést sötétzöld, a fonémaszintézist szürke, míg a szótagszegmentálást arany, szótagszintézist narancssárga és a szótagtörlést halvanysárga szinek jelölik. 


\section{2. 3. A fonológiai tudatosság teszt belső konstruktumának vizsgálata}

A teszt konstruktumának vizsgálatára a résztesztek közti korrelációk feltárását, valamint a CFA (Confirmatory Factor Analyses, megerősítő faktoranalízis) módszerét alkalmaztuk. A korrelációk vizsgálata során alkalmaztuk a reliabilitás-vizsgálat során is megjelenő nyelvi egység mérete szerinti, a müveletek szerinti, valamint a feladattípusok szerinti tagolást és vizsgáltuk a különböző területek, egységek összefüggéseit is. A nyelvi egység mérete szerinti elkülönítés esetében (16. táblázat) a szótagtudatosság és a teljes teszt között közepes korreláció figyelhető meg, míg a fonématudatosság és a teljes teszt között erős függő kapcsolat áll fenn. A két nyelvi egységet vizsgáló rész között közepes korreláció tapasztalható.

16. táblázat. A nyelvi egységek és a teljes teszt közti korrelációs együtthatók

\begin{tabular}{ccc}
\hline & Teljes teszt & Szótagszint \\
\hline Szótag szint & 0,70 & \\
Fonéma szint & 0,97 & 0,50 \\
\hline
\end{tabular}

Megjegyzés: minden korreláció szignifikáns $p<0,01$ szinten

A mủveletek között gyenge vagy közepes kapcsolat áll fenn. A leggyengébb a kapcsolat a szintézis és a szegmentálás műveletek között, míg a legerösebb a szegmentálást és az azonosítást kérő feladatok között jelentkezik (17. táblázat).

17. táblázat. A müveleti szintek és a teljes teszt közti korrelációs együtthatók

\begin{tabular}{ccccc}
\hline & Teljes teszt & Azonosítás & Szintézis & Szegmentálás \\
\hline Azonosítás & 0,92 & & & \\
Szintézis & 0,73 & 0,51 & & \\
Szegmentálás & 0,69 & 0,54 & 0,37 & \\
Törlés & 0,66 & 0,46 & 0,47 & 0,38 \\
\hline
\end{tabular}

Megjegyzés: minden korreláció szignifikáns $p<0,01$ szinten

A vizsgált feladattípusok és a teljes teszt között gyenge, közepes és magas korrelációs értékeket is találunk, a teljes teszttel leggyengébb összefüggést a szótagtörlés részteszt mutatja, míg legerősebb kapcsolat a teljes teszt és a fonémaazonosítás a hang helyének meghatározásával részteszt között áll fenn. A résztesztek között a gyenge, elhanyagolható kapcsolattól egészen a közepe korrelációs értékekig találhatunk példát. A fonémaszegmentálás és a szótagszintézis közti kapcsolat elhanyagolható, míg a résztesztek közti legerősebb 
összefüggést a fonémaazonosítás és a fonémaazonosítás a hang helyének meghatározásával résztesztek között fedezhetjük fel (18. táblázat).

Mivel a korrelációs vizsgálatok egy komplex teszt és abenne lévő szubtesztek nyelvi egység, müveletenkénti, illetve résztesztekkénti tagolódása szerint tárták fel a különböző értékeket, ezért a különböző, komplex teszten belül megjelenő kisebb egységek más-más súllyal kerültek bele az elemzésbe, a más-más itemszámok függvényében. Ezáltal az itemszámok bár befolyásolhatják a kapott eredményeket, mégis ezek az értékek elővetítik a teszt belső konstruktumának szerkezetét.

18. táblázat. A feladattípusok és a teljes teszt közti korrelációs együtthatók

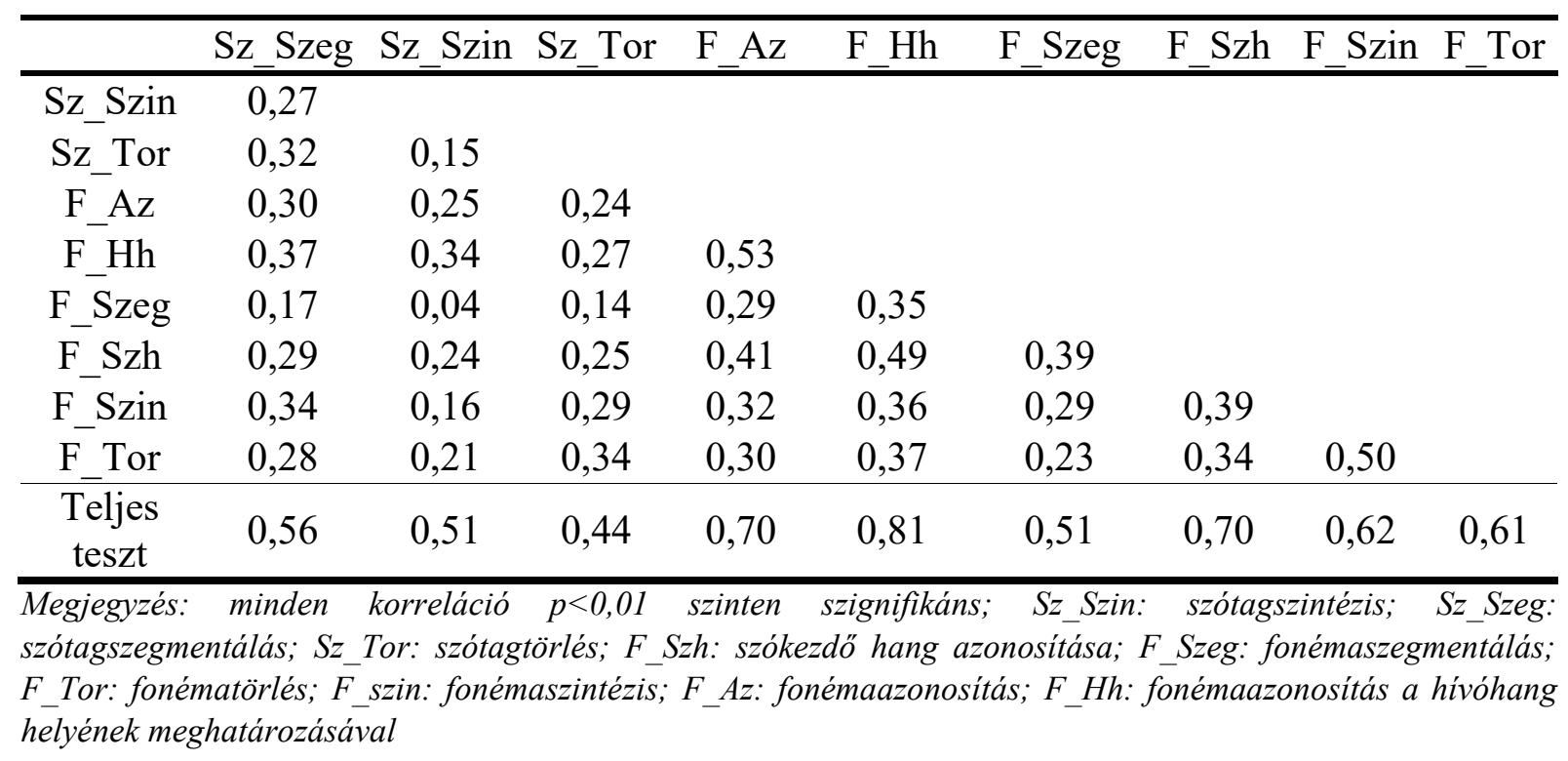

A korrelációs értékek vizsgálata, valamint vonatkozó kutatások alapján a teszt struktúrájának vizsgálatára 1-, 2-, 4-, 7- és 9-dimenziós modelleket teszteltünk. Az 1-dimenziós modellben a teljes teszt egy osztatlan egységként jelent meg, a 2-dimenziós modell a nyelvi egységek mérete (szótag és fonéma), a 4-dimenziós a feladatok mủveleti szintje (azonosítás, szegmentálás, szintézis és törlés), a 7-dimenziós nyelvi egységek szerinti bontást is tartalmazza a müveleti szintek mentén (szótagszegmentálás, szótagszintézis, szótagtörlés, fonémaazonosítás, fonémaszegmentálás, fonémaszintézis, fonématörlés), míg a 9-dimenziós a különböző feladattípusok mentén értelmezendő. Ezen dimenziók felállítása során a konstruktumon belüli rendezőelvet még nem határoztuk meg. A 7-dimenziós modell értékei bár megközelítik a modell elfogadásához szükséges értékeket, de egyedül a 9-dimenziós modell értékei tekinthetők megfelelőnek (19. táblázat). 
19. táblázat. Az elsö osztályos fonológiai tudatosság teszt megerösitő faktorelemzésének eredményei

\begin{tabular}{ccccccc}
\hline Modell & $\chi^{2}$ & $d f$ & $p$ & CFI & TLI & RMSEA (95\% CI) \\
\hline 9- dimenziós & 2043,286 & 1044 & 0,000 & 0,926 & 0,920 & $0,027(0,025-0,029)$ \\
7- dimenziós & 3155,877 & 1154 & 0,000 & 0,856 & 0,847 & $0,037(0,035-0,038)$ \\
4- dimenziós & 5443,138 & 1169 & 0,000 & 0,693 & 0,678 & $0,053(0,052-0,055)$ \\
2- dimenziós & 5939,725 & 1079 & 0,000 & 0,641 & 0,625 & $0,059(0,058-0,061)$ \\
1- dimenziós & 6787,025 & 1080 & 0,000 & 00,579 & 0,560 & $0,064(0,063-0,065)$ \\
\hline
\end{tabular}

Megjegyzés: df = degrees of freedom; CFI = Comparative Fit Index; TLI = Tucker-Lewis Index; RMSEA = Root Mean Square Error of Approximation; $\chi 2$ and df are estimated by WLSM5.

A belső szerkezet felállításához, tehát a dimenziók egymáshoz való viszonyának felállításához a konstruktum modelljének kirajzolása mellett döntöttünk, melynek az előzőekben felállított, megfelelően illeszkedő 9-dimenziós modellt vehettük és vettük alapul. Három modellstruktúrát teszteltünk (20. táblázat). Az első modellstruktúra esetében (29. ábra) feltételeztük, hogy minden dimenzió külön kapcsolódik a fonológiai tudatossághoz, mint látens változóhoz, tehát magát a látens konstruktumot a kilenc feladattípus közvetlenül határozza meg. A második modell esetében (30. ábra) a nyelvi egység méretét (szótag és fonéma) határoztuk meg elsődleges rendező elvként, tehát a fonológiai tudatosság látens konstruktumához közvetlenül a két eltérő méretü nyelvi egység kapcsolódik, a harmadik modellben (31. ábra) pedig a műveletek (azonosítás, szintézis, szegmentálás, törlés) szerinti tagolódást jelenti az elsődleges rendező elvet. Minden modell az itemekből indul ki, csupán a feladattípusok, a nyelvi egység mérete, illetve a müveletek szerinti rendezőelv konstruktum-meghatározó szerepére kívántunk rávilágítani. A kapott értékek alapján a 3. modell rendelkezik megfelelő értékekkel, így kijelenthető, hogy a teszt belső szerkezetétt a nyelvi egység méretétől függetlenül a müveleti szintek határozzák meg.

20. táblázat. Az első osztályos fonológiai tudatosság teszt belső kontsruktumának meghatározása

\begin{tabular}{lcccccc}
\hline Modell & $\chi^{2}$ & $d f$ & $p$ & CFI & TLI & RMSEA (95\% CI) \\
\hline Modell 1 & 2387,357 & 1071 & 0,000 & 0,903 & 0,898 & $0,031(0,029-0,033)$ \\
Modell 2 & 2387,249 & 1069 & 0,000 & 0,903 & 0,897 & $0,031(0,029-0,033)$ \\
Modell 3 & 2286,649 & 1067 & 0,000 & 0,910 & 0,905 & $0,030(0,028-0,032)$ \\
\hline
\end{tabular}


Megjegyzés: $d f=$ degrees of freedom; $C F I=$ Comparative Fit Index; TLI = Tucker-Lewis Index; RMSEA $=$ Root Mean Square Error of Approximation; $\chi 2$ and $d$ are estimated by WLSM5.

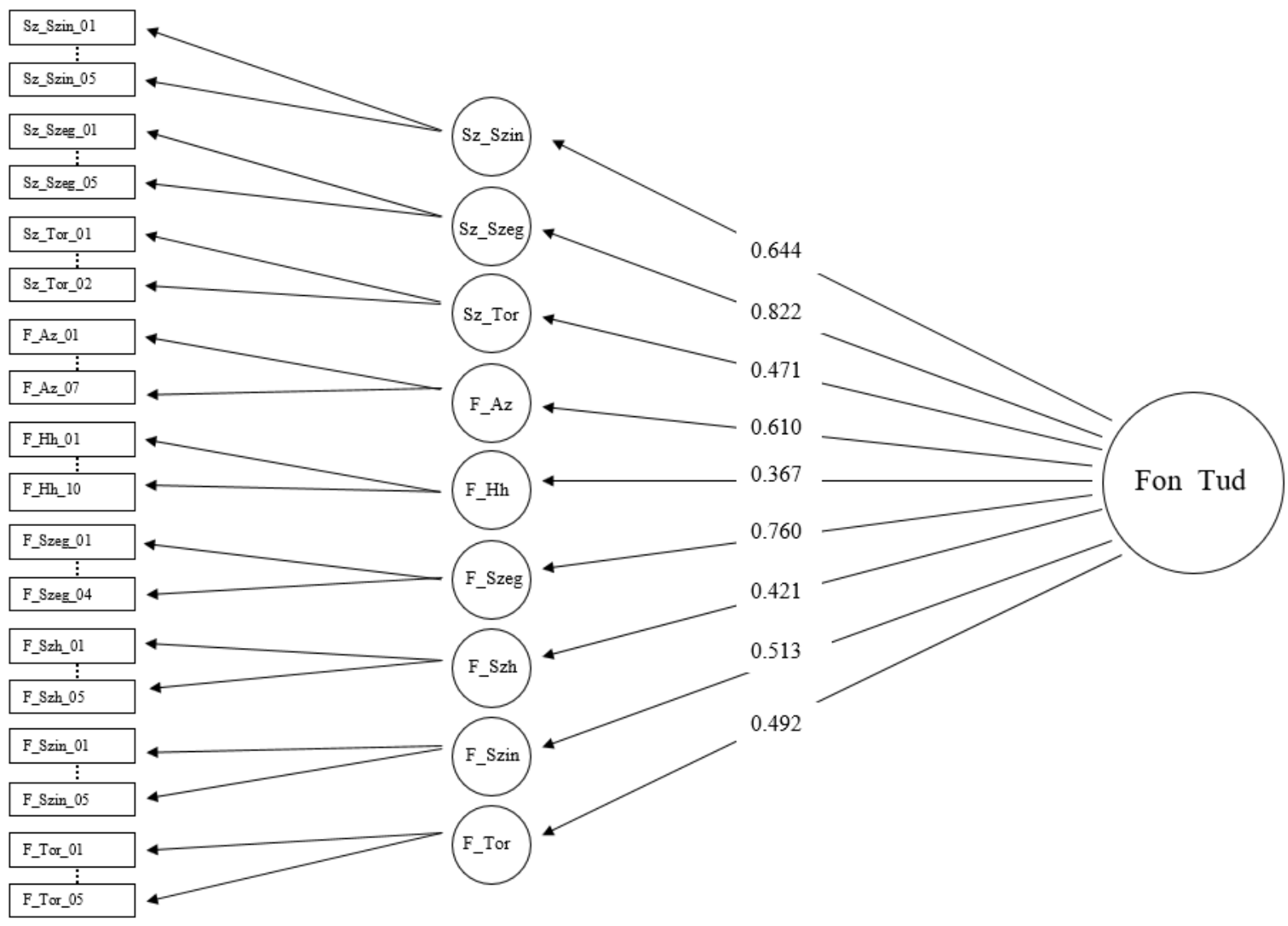

298. ábra

Az elsö évfolyamos fonológiai tudatosság teszt hierarchikus faktorelemzése, 1. modell Fon_tud: fonológiai tudatosság; Sz_Szin: szótagszintézis; Sz_Szeg: szótagszegmentálás; Sz_Tor: szótagtörlés; $F$ Szh: szókezdö hang azonositása; $F \_$Szeg: fonémaszegmentálás; F_Tor: fonématörlés; $F \_s z i n:$ fonémaszintézis; $F \_$Az: fonémaazonositás; $F \_h h$ : fonémaazonositás a hivóhang helyének meghatározásával 


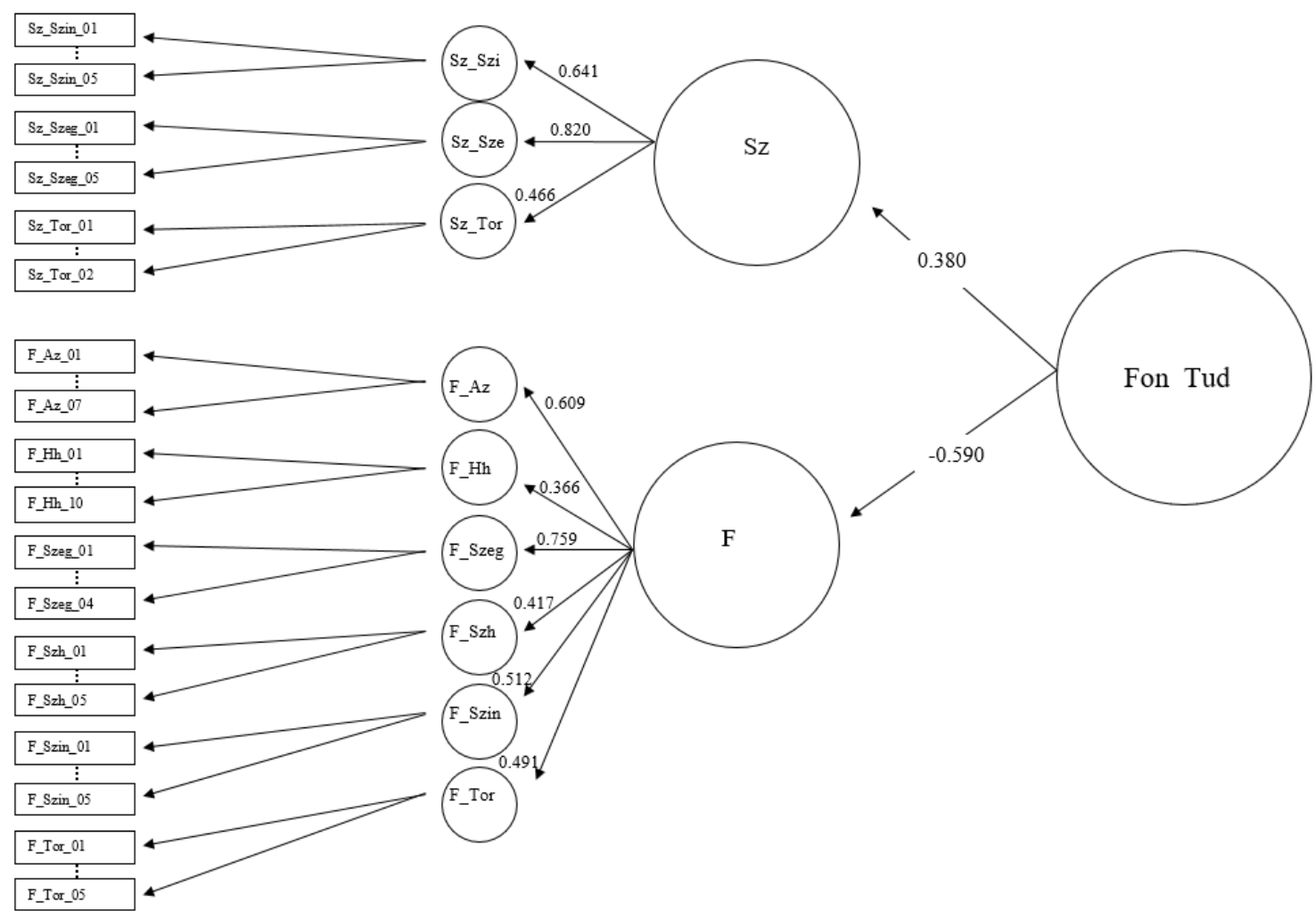

30. ábra

Az elsö évfolyamos fonológiai tudatosság teszt hierarchikus faktorelemzése, 2. modell. Fon_tud: fonológiai tudatosság; Sz: szótag; F: fonéma; Sz_Szin: szótagszintézis; Sz_Szeg: szótagszegmentálás; Sz_Tor: szótagtörlés; $F \_S z h$ : szókezdö hang azonositása; $F$ Szeg: fonémaszegmentálás; $F$ Tor: fonématörlés; $F$ szin: fonémaszintézis; $F \_$Az: fonémaazonositás; $F \_$hh: fonémaazonositás a hívóhang helyének meghatározásával 


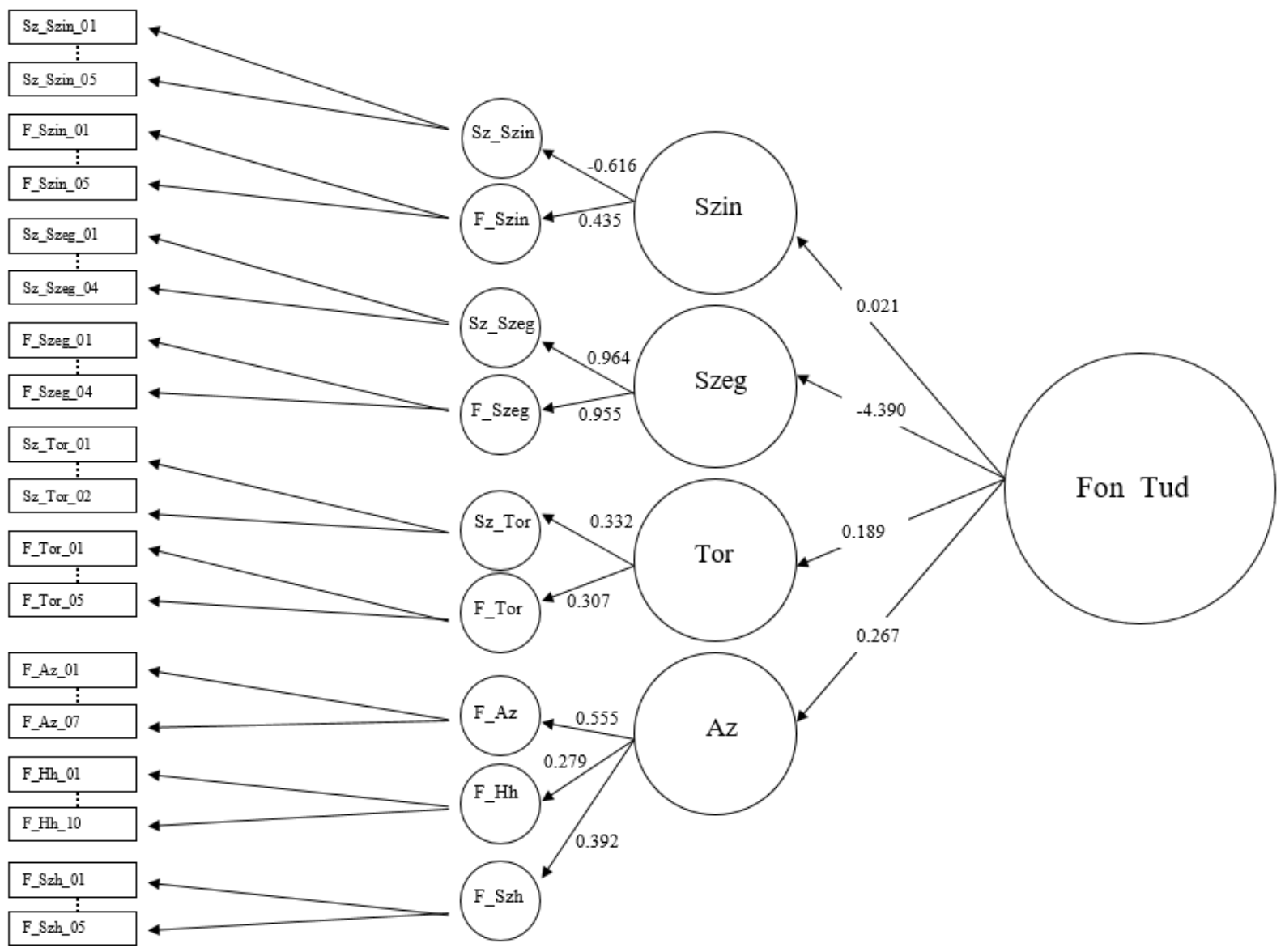

31. ábra

Az elsö évfolyamos fonológiai tudatosság teszt hierarchikus faktorelemzése, 3. modell Az itemek faktorsúlyait a 3. melléklet tartalmazza. Fon_tud: fonológiai tudatosság; Sz: szótag; F: fonéma; Sz_Szin: szótagszintézis; Sz_Szeg: szótagszegmentálás; Sz_Tor: szótagtörlés; $F \_S z h:$ szókezdö hang azonositása; $F_{-}$Szeg: fonémaszegmentálás; $F_{-}$Tor: fonématörlés; $F \_$szin: fonémaszintézis; $F \_$Az: fonémaazonositás; $F$ hh: fonémaazonositás a hivóhang helyének meghatározásával; Szin: szintézis; Szeg: szegmentálás; Tor: törlés; Az: azonositás

A vonatkozó alapján CFI és TLI értékek alapján (20. táblázat) a 3. modell tekinthető elfogadhatónak. A modell (31. ábra) az itemektől indul ki, majd a kilenc feladattípusokon és négy müveleti szinten keresztül határozza meg a fonológiai tudatosságot mint látens konstruktumot. Az azonosítás látens változóján kívül mindhárom müveleti szinthez (szintézis, szegmentálás, törlés) szótag- és fonémaszintű feladatok is kapcsolódnak, míg az azonosítás müveletét csak fonémaszintű feladatok alkotják. A szintézis és szegmentálás müveletének esetében a fonémaszintü, míg a törlés esetében a szótagszintü feladatok kapcsolodnak a müveleti szintü látmüveleti szintek A faktorsúlyokból egyértelmüen leolvasható, hogy a 
szegmentálás látens változója határozza meg legkevésbé a fonológiai tudatosságot mint látens konstruktumot. Az itemek az ábra bal oldalán találhatók, téglalappal jelezve. Az egyes itemek között szaggatott vonal látható, mely jelzi, hogy az adott résztesztet az ábrán feltüntetettnél több item alkotta. Az itemek faktorsúlyait az 5. melléklet tartalmazza.

\section{2. 4. A tanulók teszten elért teljesítményének vizsgálata}

A teszt megbízhatóságának és konstruktumának vizsgálata után a diákok teszten elért teljesítményét is vizsgálni kívánjuk. A tanulók teljes teszten elért átlagteljesítménye $57,80 \%$ pont volt, mely nagymértékben nem tér el a pszichometrikailag kívánatos 50\%-tól. A teljes teszt szórása 19,17\%pont, ami egyrészről jelzi a teszt megfelelő differenciáló erejét, másrészt a tanulók közötti nagy különbségekre is rámutat. Az eredmények alapján megállapítható, hogy a szótagszintézis feladatok bizonyultak a legkönnyebbnek, a gyermekek átlagos teljesítménye 87,12\%pont volt. Az átlagteljesítmények alapján legnehezebbnek bizonyult a fonémaszegmentálás feladattípus (31,01\%pont). A szórások értékei alapján megállapítható, hogy a részterületek közül legkevésbé a szótagszintézis, míg leginkább szótagszegmentálás feladattípus differenciált. Az értékek áttekintése során a feladatok itemszáma is meghatározó tényező, hiszen az egyes résztesztek között akár 8 item különbség is jelentkezik (21. táblázat).

\section{1. táblázat. A tanulók teszten elért teljesitményének átlaga és szórása}

\begin{tabular}{ccccc}
\hline Feladattípus & $\begin{array}{c}\text { Itemek } \\
\text { száma }\end{array}$ & $\begin{array}{c}\text { Átlag } \\
\%\end{array}$ & $\begin{array}{c}\text { Szórás } \\
\%\end{array}$ & $\mathrm{~N}$ \\
\hline Szótagszintézis & 5 & 87,12 & 21,81 & 1301 \\
Szótagszegmentálás & 5 & 39,94 & 35,89 & 1300 \\
Szótagtörlés & 2 & 73,19 & 33,90 & 1300 \\
Fonémaazonosítás & 7 & 53,46 & 27,41 & 1300 \\
Fonémaazonosítás a hívóhang & 10 & 48,63 & 28,68 & 1298 \\
helyének meghatározásával & & 49,01 & 34,98 & 1297 \\
Szókezdö hang azonosítása & 5 & 78,38 & 27,82 & 1295 \\
Fonémaszintézis & 5 & 31,01 & 34,73 & 1295 \\
Fonémaszegmentálás & 4 & 75,35 & 27,94 & 1293 \\
Fonématörlés & 5 & $\mathbf{5 7 , 8 0}$ & $\mathbf{1 9 , 1 7}$ & $\mathbf{1 2 9 1}$ \\
\hline Teljes teszt & $\mathbf{4 8}$ & & &
\end{tabular}

A tanulók képességeinek árnyaltabb feltárását szolgálja a teljes teszten és a feladattípusokon nyújtott teljesítmények eloszlása is. A Kolmogorov-Smirnov teszt szerint (22. táblázat) az eloszlások jobbra aszimmetrikusak a szótagszintézis, a szótagtörlés, a 
fonémaazonosítás, a szókezdő hang azonosítása, a fonémaszintézis és fonématörlés feladattípusok, és a teljes teszt esetében, azaz a normál eloszláshoz képest több tanuló ért el magasabb teljesítményt, valamint az eloszlások lapultabbak a szótagszegmentálás, szótagtörlés, fonémaazonosítás, a fonémaazonosítás a hívóhang helyének meghatározásával, a szókezdő hang azonosítása, a fonémaszegmentálás és a teljes teszt esetében, tehát ezeken a részteszteken nyújtott teljesítmény a normál eloszláshoz képest alacsonyabb és egyenletesebb volt. Mind résztesztek, mind a teljes teszt eloszlása szignifikánsan eltér a normál eloszlástól.

22. táblázat. A teljes teszt és a feladattípusok eloszlásainak statisztikai mutatói

\begin{tabular}{cccccc}
\hline Feladattípus & $\begin{array}{c}\text { skewness } \\
\text { (szimmetria) }\end{array}$ & $\begin{array}{c}\text { kurtosis } \\
\text { (lapultság) }\end{array}$ & $\begin{array}{c}\text { Kolmogorov- } \\
\text { Szmirnov } \\
\text { teszt }\end{array}$ & df & $\mathrm{p}$ \\
\hline Szótagszintézis & $-2,102$ & 4,293 & 0,186 & 1294 & $<0,01$ \\
$\begin{array}{c}\text { Szótagszegmentálás } \\
\text { Szótagtörlés }\end{array}$ & 0,326 & $-1,293$ & 0,356 & 1294 & $<0,01$ \\
Fonémaazonosítás & $-0,889$ & $-0,404$ & 0,355 & 1294 & $<0,01$ \\
Fonémaazonosítás a & $-0,017$ & $-0,994$ & 0,130 & 1294 & $<0,01$ \\
hívóhang helyének & 0,197 & $-1,023$ & 0,127 & 1294 & $<0,01$ \\
meghatározásával & & & & & \\
Szókezdő hang & $-0,022$ & $-1,295$ & 0,139 & 1294 & $<0,01$ \\
azonosítása & $-1,283$ & 0,717 & 0,267 & 1294 & $<0,01$ \\
Fonémaszintézis & 0,789 & $-0,721$ & 0,252 & 1294 & $<0,01$ \\
Fonémaszegmentálás & Fon & & & & \\
Fonématörlés & $-1,127$ & 0,448 & 0,241 & 1294 & $<0,01$ \\
\hline Teljes teszt & $\mathbf{- 0 , 2 5 7}$ & $\mathbf{- 0 , 2 8 2}$ & $\mathbf{0 , 0 4 5}$ & $\mathbf{1 3 0 1}$ & $<\mathbf{0 , 0 1}$ \\
\hline
\end{tabular}

\section{2. 5. A tanulók teljesítményének eloszlása nemük szerint}

A nemek közti különbségek vizsgálata során elsőként a teljes teszt és adott nem közti korrelációs értéket vizsgáltuk. Az elemzések során a fiúkat az 1-es, míg a lányokat a 2-es változó jellemzi, így ha a korrelációs együttható értéke pozitív, akkor a lányok, ha negatív, akkor a fiúk teljesítménybeli előnyét jelzi. A teljes teszt és a nem közötti korrelációs együttható értéke $\mathrm{r}=0,02$, az összefüggés nem szignifikáns ( $\mathrm{p}>0,05)$. Mivel a korreláció pozitív értékü, ezért a tendencia a lányok előnyét mutatja (23. táblázat).

A teljes teszttel való összefüggésen kívül vizsgáltuk a nyelvi egység mérete, a műveletek, valamint a feladattípusok közti összefüggéseket is. A nyelvi egység nagysága szerinti tagolódás és a nemek között nem találtunk szignifikáns összefüggést, a műveleti elkülönítés alapján pedig egyedül a nyelvi egységek törlését kérő feladatok mutatják a lányok szignifikáns 
teljesítménybeli előnyét. A résztesztek során a fonémaszintézis esetében mutatkozott még szignifikáns különbség szintén a lányok javára (24. táblázat).

23. táblázat. A nem és résztesztek közti korrelációs együtthatók értékei, a vonatkozó szignifikancia értékek és a mintaelemszáma

\begin{tabular}{cccc}
\hline Feladattípus & nem & $\mathrm{p}$ & $\mathrm{N}$ \\
\hline Szótagszintézis & 0,00 & 0,89 & 1183 \\
Szótagszegmentálás & $-0,01$ & 0,84 & 1183 \\
Szótagtörlés & 0,05 & 0,08 & 1183 \\
Fonémaazonosítás & $-0,02$ & 0,56 & 1183 \\
Fonémaazonosítás a & & & \\
hívóhang helyének & $-0,02$ & 0,54 & 1183 \\
meghatározásával & & & \\
Szókezdő hang & 0,02 & 0,41 & 1181 \\
azonosítása & $0,07^{*}$ & 0,02 & 1180 \\
Fonémaszintézis & 0,00 & 0,85 & 1182 \\
Fonémaszegmentálás & 0,06 & 0,06 & 1179 \\
Fonématörlés & $-0,01$ & 0,81 & 1183 \\
\hline Azonosítás & 0,04 & 0,15 & 1183 \\
Szintézis & 0,00 & 0,96 & 1183 \\
Szegmentálás & $0,06^{*}$ & 0,03 & 1183 \\
Törlés & 0,01 & 0,63 & 1183 \\
Szótag & 0,02 & 0,52 & 1183 \\
Fonéma & $\mathbf{0 , 0 2}$ & $\mathbf{0 , 5 0}$ & $\mathbf{1 1 8 3}$ \\
\hline Teljes teszt & &
\end{tabular}

24. táblázat. A fonológiai tudatosság fejlettsége az általános iskola elsö osztályos tanulók körében

\begin{tabular}{|c|c|c|c|c|c|c|c|c|c|}
\hline \multirow{2}{*}{ Feladattípus } & \multirow{2}{*}{$\mathrm{Nem}$} & \multirow{2}{*}{$\mathrm{N}$} & \multirow{2}{*}{$\begin{array}{c}\text { Átlag } \\
(\%)\end{array}$} & \multirow{2}{*}{$\begin{array}{c}\text { Szórás } \\
(\%)\end{array}$} & \multicolumn{2}{|c|}{ Levene } & \multirow{2}{*}{$\mathrm{t}$} & \multirow{2}{*}{ df } & \multirow[b]{2}{*}{$\mathrm{p}$} \\
\hline & & & & & $\mathrm{F}$ & $\mathrm{p}$ & & & \\
\hline \multirow{2}{*}{ Szótagszegmentálás } & fiú & 616 & 41 & 35,2 & \multirow{2}{*}{1,10} & \multirow{2}{*}{0,29} & \multirow{2}{*}{$-0,14$} & \multirow{2}{*}{1167,04} & \multirow{2}{*}{0,89} \\
\hline & lány & 567 & 41,1 & 36,2 & & & & & \\
\hline \multirow{2}{*}{ Szótagszintézis } & fiú & 616 & 88,2 & 20,8 & \multirow{2}{*}{0,25} & \multirow{2}{*}{0,62} & \multirow{2}{*}{0,20} & \multirow{2}{*}{1181} & \multirow{2}{*}{0,84} \\
\hline & lány & 567 & 88 & 20 & & & & & \\
\hline \multirow{2}{*}{ Szótagtörlés } & fiú & 616 & 72 & 34,5 & \multirow{2}{*}{7,05} & \multirow{2}{*}{0,01} & \multirow{2}{*}{$-1,76$} & \multirow{2}{*}{1180,97} & \multirow{2}{*}{0,078} \\
\hline & lány & 567 & 75,5 & 32 & & & & & \\
\hline \multirow{2}{*}{ Fonémaazonosítás } & fiú & 616 & 55 & 27 & \multirow{2}{*}{1,02} & \multirow{2}{*}{0,31} & \multirow{2}{*}{0,58} & \multirow{2}{*}{1181} & \multirow{2}{*}{0,56} \\
\hline & lány & 567 & 54 & 27,86 & & & & & \\
\hline \multirow{2}{*}{$\begin{array}{l}\text { Fonémaazonosítás a } \\
\text { hívóhang helyének } \\
\text { meghatározásával }\end{array}$} & fiú & 616 & 50,3 & 28,6 & \multirow{2}{*}{0,00} & \multirow{2}{*}{0,96} & \multirow{2}{*}{0,61} & & 054 \\
\hline & lány & 567 & 49,3 & 20,84 & & & & 1181 & 0,54 \\
\hline álás & fiú & 615 & 31,25 & 35 & ב0 0 ר & 080 & -0 & 1180 & 085 \\
\hline 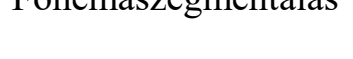 & lány & 567 & 31,5 & 35 & 0,02 & 0,07 & & & $0,0 J$ \\
\hline & fiú & 614 & 49,4 & 34,8 & 0,20 & 0,65 & $-0,82$ & 1179 & 0,41 \\
\hline
\end{tabular}




\begin{tabular}{|c|c|c|c|c|c|c|c|c|c|}
\hline $\begin{array}{l}\text { Szókezdő hang } \\
\text { azonosítása }\end{array}$ & lány & 567 & 51 & 34,4 & & & & & \\
\hline \multirow{2}{*}{ Fonémaszintézis } & fiú & 614 & 77,4 & 28 & \multirow{2}{*}{7,34} & \multirow{2}{*}{0,01} & \multirow{2}{*}{$-2,32$} & \multirow{2}{*}{1177,93} & \multirow{2}{*}{0,02} \\
\hline & lány & 566 & 81 & 25,6 & & & & & \\
\hline \multirow{2}{*}{ Fonématörlés } & fiú & 614 & 74,8 & 28,6 & \multirow{2}{*}{10,23} & \multirow{2}{*}{0,00} & \multirow{2}{*}{$-1,92$} & \multirow{2}{*}{1176,58} & \multirow{2}{*}{0,05} \\
\hline & lány & 565 & 77,8 & 25,8 & & & & & \\
\hline \multirow[t]{2}{*}{ Szintézis } & fiú & 616 & 59,1 & 24,2 & \multirow{2}{*}{0,07} & \multirow{2}{*}{0,79} & \multirow{2}{*}{$-1,45$} & \multirow{2}{*}{1181} & \multirow{2}{*}{0,15} \\
\hline & lány & 567 & 61,1 & 23,7 & & & & & \\
\hline \multirow[t]{2}{*}{ Szegmentálás } & fiú & 616 & 62,89 & 20,78 & \multirow{2}{*}{0,02} & \multirow{2}{*}{0,9} & \multirow{2}{*}{$-0,05$} & \multirow{2}{*}{1181} & \multirow{2}{*}{0,96} \\
\hline & lány & 567 & 62,89 & 20,56 & & & & & \\
\hline \multirow[t]{2}{*}{ Törlés } & fiú & 616 & 73,86 & 25,86 & \multirow{2}{*}{7,85} & \multirow{2}{*}{0,01} & \multirow{2}{*}{$-2,2$} & \multirow{2}{*}{1180,14} & \multirow{2}{*}{0,03} \\
\hline & lány & 567 & 77 & 23,14 & & & & & \\
\hline \multirow[t]{2}{*}{ Azonosítás } & fiú & 616 & 51,55 & 24,09 & \multirow{2}{*}{0,07} & \multirow{2}{*}{0,8} & \multirow{2}{*}{0,24} & \multirow{2}{*}{1181} & 0.81 \\
\hline & lány & 567 & 51,18 & 24,09 & & & & & \\
\hline Szótao & fiú & 616 & 65,92 & 20,83 & 0.24 & 062 & -0.49 & 1181 & 0.63 \\
\hline & lány & 567 & 65,75 & 21 & & 0,02 & $-0,4\rangle$ & & \\
\hline Fonéma & fiú & 616 & 56,03 & 21,33 & 0.81 & 0.37 & -0.64 & 1181 & 0.52 \\
\hline & lány & 567 & 56,83 & 20,25 & 0,01 & ו & $-0,04$ & & (0, \\
\hline Telies teszt & fiú & 616 & 58,48 & 19,12 & 0.19 & 0.66 & -0.68 & 1181 & 0.5 \\
\hline & lány & 567 & 59,23 & 18,14 & & & & & , \\
\hline
\end{tabular}

\section{2. 6. A tanulók teljesítményének eloszlása életkoruk szerint}

Az általános iskola első osztálya széles korcsoportot fed le. Egyrészt olyan tanulók is találhatók első osztályban, akik valami miatt óvodai csoportot ismételtek, tehát több mint 3 évet töltöttek a közoktatás legalsóbb szintjén, de vannak olyan tanulók is, akik koruk szerint elérték a tankötelesség alsó korhatárát, és iskolába léptek. Így a mintában 2006-2009 között született gyermekek egyaránt szerepelnek. Mivel a legfiatalabb és legidősebb korcsoportok átlagéletkora között 2,42 év korkülönbség is fellelhető, ezért érdemes a mintát korcsoportokra bontani. A tanulók életkorának vizsgálata során megnéztük, hogy milyen átlagéletkor és szórás jellemezte a vizsgált mintát. A korcsoportok átlagéletkorát és annak szórását az 25 . táblázat tartalmazza. A táblázatból leolvasható, hogy a mintában legkisebb elemszámmal a 2006-os születésű tanulók (12 fö), míg legnagyobb elemszámmal a 2008-ban született tanulók képviseltetik magukat (893 fö). 


\begin{tabular}{lccc}
\hline Születési év & $\begin{array}{c}\text { Átlagéletkor } \\
(\text { év) }\end{array}$ & $\begin{array}{c}\text { Szórás } \\
\text { (év) }\end{array}$ & $\mathrm{N}$ \\
\hline 2006 & 8,83 & 0,58 & 12 \\
2007 & 7,60 & 0,49 & 86 \\
2008 & 6,78 & 0,41 & 893 \\
2009 & 6,11 & 0,17 & 310 \\
\hline
\end{tabular}

A legjobb átlagteljesítményt a 2009-ben született gyermekek érték el, de a legnagyobb szórás érték is ehhez a korcsoporthoz köthető (26. táblázat). A születési év tekintetében szignifikáns különbség nem tapasztalható az életkor és az összteljesítmény tekintetében ( $\mathrm{F}(3$, 1297) $=3,02, p>0,05)$. Hasonlóan a korábbi elemzésekhez, a nyelvi egység mérete, müveleti szintü és résztesztenkénti bontást is tanulmányoztuk. Szignifikáns különbséget találtunk a műveleti egységek tekintetében a szintézis $(F(3,1297)=3,64 p<0,05)$ és az azonosítás $(F(3$, $1297)=3,88 \mathrm{p}<0,01)$, valamint a résztesztek szintjén a szótagszintézis esetében $(\mathrm{F}(3$, 1297)=3,75 p<0,05). A variancianalízis Tukey’s-b post hoc elemzése alapján, az azonosítás műveleti szint esetében a 2008-as és 2009-es születésű tanulók szignifikánsan jobban teljesítettek 2007-es társaikhoz képest, a szótagszintézis részteszt esetében pedig a 2008-as születésűek nyújtottak szignifikánsabb jobb teljesítményt a 2006-os születésű tanulóknál. A szintézis művelet esetében, Dunnett's post hoc teszt alapján, a 2008-as és 2009-es tanulók esetében szignifikánsan jobb teljesítmény tapasztalható, mint a 2007-es tanulók esetében, tehát az azonosítást és a szintézist kérő feladatok esetében ugyanaz a tendencia rajzolódik ki.

26. táblázat. A tanulók teljesitményének átlaga és szórása a születési év függvényében

\begin{tabular}{lccc}
\hline Születési év & $\begin{array}{c}\text { Átlag } \\
(\%)\end{array}$ & $\begin{array}{c}\text { Szórás } \\
(\%)\end{array}$ & N \\
\hline 2006 & 50,87 & 18,81 & 12 \\
2007 & 52,50 & 18,12 & 86 \\
2008 & 58,08 & 19,05 & 893 \\
2009 & 58,69 & 19,60 & 310 \\
\hline
\end{tabular}

Mivel az első osztályosok körében az adott születési év a készség- és képességfejlődés nagy intervallumát fedi le, ezért az életkori csoportok féléves bontása mellett döntöttünk. A minta féléves bontását, illetve a mintaelemszámát és a tanulók teszten elért teljesítményét az 27. táblázat tartalmazza. A féléves életkori csoportok és az összteljesítmény tekintetében 
szignifikáns különbség tapasztalható $(\mathrm{F}(7,1293)=2,12, \mathrm{p}=0,04)$, viszont post hoc teszt eredményei alapján nem állapítható meg, hogy ezen különbség mely részminták között jelentkezett.

27. táblázat. A tanulók teljesitményének átlaga és szórása a születési félév függvényében

\begin{tabular}{ccccc}
\hline Születési félév & $\begin{array}{c}\text { Átlag } \\
(\%)\end{array}$ & $\begin{array}{c}\text { Szórás } \\
(\%)\end{array}$ & N \\
\hline \multirow{2}{*}{2006} & 1. félév & 41,67 & 22,54 & 3 \\
& 2. félév & 53,94 & 17,81 & 9 \\
\multirow{2}{*}{2007} & 1. félév & 48,60 & 21,11 & 15 \\
& 2. félév & 53,31 & 17,50 & 71 \\
\multirow{2}{*}{2008} & 1. félév & 56,58 & 19,20 & 264 \\
& 2. félév & 58,73 & 18,97 & 629 \\
\multirow{2}{*}{2009} & 1. félév & 59,42 & 18,92 & 247 \\
& 2. félév & 55,81 & 22,00 & 63 \\
\hline
\end{tabular}

A nyelvi egység mérete szerint a szótag szintű feladatok $(F(7,1293)=2,23 p<0,05)$, a múveleti szintek szerint a szintézis $(F(7,1293)=2,42 p<0,05)$ és az azonosítás $(F(7,1293)=2,48 p<0,05)$, míg résztesztenkénti bontás esetében a szókezdő hang azonosítása $(F(7,1289)=2,37 \mathrm{p}<0,05)$ és a szótagszintézis esetében $(F(7,1293)=2,44 p<0,05)$ jelennek meg a születési félév szerinti szignifikáns különbségek. A variancianalízis Tukey’s-b post hoc elemzése alapján a szótag szintü feladatok és a szintézis esetében ugyanaz a jelenség tapasztalható, mint az összteljesítmény és a születési félévek ANOVA elemzése során. Bár a különbség szignifikánsnak mondható ( $\mathrm{p}_{\text {szótag }}=0,03, \mathrm{p}_{\text {szintézis }}=0,02$ ) a post hoc teszt alapján nem állapítható meg, hogy mely korcsoportok között jelentkezik számottevő különbség. Az azonosítást kérő itemek esetében a 2008. 2. félévében és a 2009. 1. félévében született tanulók szignifikánsan jobban teljesítettek a 2006. 1. félévében született tanulóknál. A szókezdő hang azonosítása esetében és a szótagszintézis feladattípus esetében a 2008. 2. félévében született gyermekek jobban teljesítettek a 2007. 1. félévében született tanulóknál.

\section{2. 7. A fonológiai tudatosság teszt és a géphasználat teszt összefüggése általános}

\section{iskola első osztályában}

A fonológiai tudatosság teszt során a tanulók mind kattintást, mind vonszolást igénylő feladattípusokkal is találkoztak. Ebből kifolyólag a géphasználat teszt és a fonológiai tudatosság teszt összefüggését három szempontból vizsgáltuk (28. táblázat). Egyrészt kíváncsiak voltunk a géphasználat teszt és a teljes teszt, másrészt a kattintást igénylő géphasználat feladatok és a fonológiai tudatosság teszt azonos műveletét kívánó feladatai, 
harmadrészt pedig a géphasználat teszt vonszolást és a fonológiai tudatosság teszt vonszolást igénylö feladatai között fellépő magyarázóerő nagyságára.

A teljes géphasználat teszt 9,3\%-ban magyarázza a fonológiai tudatosság teszten nyújtott teljesítményt $(\mathrm{F}(1,1299)=133,32, \mathrm{p}<0,01)$, a vonszolást igénylő feladatok esetében $8,9 \%(\mathrm{~F}(1$, $1299)=126,74 \mathrm{p}<0,01)$, a kattintást kérő feladatok esetében pedig 2,9\% $(\mathrm{F}(1,1299)=38,54$, p<0,01) a megmagyarázott variancia. A magyarázóerő mindhárom esetben szignifikáns.

28. táblázat. A géphasználat teszt és a fonológia tudatosság teszt összefüggésének vizsgálata az általános iskola első osztályos tanulóinak körében

\begin{tabular}{cccccc}
\hline & $\mathrm{r}$ & $\beta$ & $\mathrm{r} \beta^{*} 100$ & $\mathrm{p}$ & $\mathrm{r}^{2}$ \\
\hline Teljes teszt & 0,31 & 0,31 & 9,61 & $<0,01$ & 0,10 \\
Kattintás & 0,17 & 0,17 & 2,89 & $<0,01$ & 0,03 \\
Vonszolás & 0,30 & 0,30 & 8,88 & $<0,01$ & 0,09 \\
\hline
\end{tabular}

\section{3. Az első osztályosok körében végzett vizsgálat eredményeinek összefoglalása}

2015-ben egy, a fonológiai tudatosság számos feladattípusát lefedő online, fonológiai tudatosság teszt kifejlesztésére vállalkoztunk, melyet az általános iskola első osztályos tanulói számára fejlesztettünk. A tesztet a Szegedi Tudományegyetem Oktatáselméleti Kutatócsoport partneriskolai hálózatának első osztályos tanulói töltötték ki. A bevont minta jellemzése során, bár nem tapasztaltunk szignifikáns különbséget a KSH vonatkozó adatai és a minta eloszlása kapcsán, a próba segítségével sem tudjuk elutasítani a reprezentativitást, ugyanakkor az 5. 1. 1. fejezet diagramjaiból (12-17. ábra) jól látszik, hogy a minták eloszlása különbözik az KSH országos eloszlásától. Regionálisan azt tapasztalhatjuk, hogy túlnyomórészt dél-alföldi tanulók töltötték ki a tesztet, a megyei eloszlás vizsgálatánál is leginkább Csongrád megye képviseltette magát.

A fonológiai tudatosság mérésére kifejlesztett teszt, 1301 tanuló bevonásával megbízható mérőeszköznek bizonyult az általános iskola első osztályos tanulói számára. Az eredményekből viszont látszik, hogy a bár a fonémaazonosításra vonatkozó feladatok nem elhagyhatók a konstruktum mérése során, mégis a feladatok méröértéke elmarad a kívánatos Cronbach- $\alpha$ értéktől. Az itemek elkülönítés mutatóinak vizsgálata, azaz az alacsony korrelációs értékek miatt összesen 7 item eltávolítása mellett döntöttünk. A szótagtörlés feladattípus így rendkívül alacsony reliabilitással és mintaelemszámmal jelent meg a konstruktumban, és szintén alacsonynak tekinthető a fonémaazonosítás dichotóm feladatainak megbízhatósága is. 
A személy-item térkép eredményei alapján megállapítható, hogy a feladatok a nyelvi egység méretétől függetlenül, az adott müveleti komponensek mentén különülnek el. A gyermekek számára a szegmentálás mủveleti szint feladatai bizonyultak a legnehezebbnek, majd ezt követték az azonosítást, törlést és szintézist kérő feladatok. A feladatok nehézségi szintjének kapott rendezőelve ellentmond az eddig tapasztalt, illetve elvárt nehézségi sorrendnek, hiszen az azonosítás feladatok esetében a tanulók számára, akiket már hasonló tesztekkel az iskolakészültségi mérések során (pl. a DIFER beszédhanghallás résztesztje) vizsgáltak, és ezeken a szemtől szembeni teszteken megfelelö teljesítményt nyújtottak, viszonylag nehéznek bizonyult az azonosítást kérő feladatok megválaszolása.

A teszt belső konstruktumának felállítását a vonatkozó irodalmon túl a személy-és itemtérkép, valamint a teszten belüli korrelációs értékek is előkészítették. Azon hipotézisunk, mely szerint a nyelvi egység mérete és az azzal végrehajtott müvelet együtt határozza meg a konstrukumot, megdőlni látszik. Bár az irodalom jelzi, hogy különböző életkori szakaszokban, illetve a vizsgált területek függvényében a teszt belső konstruktuma módosulhat, jelen vizsgálat esetében a müveletek szerinti tagolódás a meghatározó (31. ábra).

A tanulók teszten elért teljesítményének vizsgálata során megállapítható, hogy a fonológiai tudatosság teszt az összteszt tekintetében a pszichometrikailag kívánatos $50 \%$-tól csak kis mértékben tér el, viszont egyes résztesztek szórása egyes feladattípusok differenciáló erejére hívja fel a figyelmet. A nemek szerinti bontás esetében az összteszt tekintetében bár a lány tanulók átlagosan jobb teljesítményt értek el, a tanulók nemek közti teljesítménykülönbsége nem szignifikáns. A törlés művelete és a fonémaszintézis feladattípus esetében viszont kimutatható szignifikáns teljesítménybeli különbség a lány tanulók számára.

Az általános iskola első osztálya fejlettségi szintjük és életkorukban és rendkívül széles réteget fed le. Jelen mintában négy évfolyam gyermekei szerepelnek. Az éves mellett a tanulókat féléves életkori szakaszokra történő bontás mellett is jellemeztük, hiszen bár egyéb háttéradat hiányában, de feltételezhető, hogy azon tanulók, akik az adatfelvétel időpontjában bár kis számmal (12 tanuló), de 8 . vagy 9. életévüket betöltve első osztályosok, egyéb meghatározó háttértényezők miatt töltöttek a kötelezően elöírtnál több évet óvodai környezetben. A minta életkor szerinti eloszlásából látszik, hogy többnyire 7. életév körül kerültek beiskolázásra a gyermekek (átlagosan 6,78 évesen). Összteszt szinten azok a gyermekek érték el a legjobb teljesítményt, akik átlagosan 6,11 évesek voltak a teszt rögzítésének idejében, valamint a feladatok az ö teljesítményüket differenciálták a leginkább, tehát ők azok, aki valóban a tanköteles kor szerint kezdték meg az általános iskola első osztályát. 
Mivel a teszt online környezetben jelent meg, ezért fontos azt is vizsgálnunk, hogy jelentkezett számottevő médiahatás a feladatok megoldása során. A vonszolást kérő feladatok esetében, valamint a teljes géphasználat és a fonológiai tudatosság teszt között fellépö megmagyarázott variancia kiugróan magas a kattintást kérő feladatok esetében tapasztalható értéknél, ezért indokoltnak láttuk, hogy a következő mérési szakaszra a szegmentálás feladattípus megjelenési formáját megváltoztassuk, hiszen ez volt az egyetlen feladattípus, mely a drag \& drop funkció alkalmazását, azaz vonszolást kér a tanulóktól.

Összességében elmondható, hogy az általános iskola első osztályos tanulói körében rögzített fonológiai tudatosság teszt megbízható mérőeszköznek bizonyult. A további tesztfejlesztési munkák során mindenképp fontos megállapítás, hogy a teszt eredményei a nyelvi egység nagyságával szemben, a müveletek meghatározó szerepét emelik ki, így a teszt konstruktumának, valamint a két nyelvi szint együttes beemelésének újragondolására ösztönöznek. A médiahatás csökkentésére célszerünek tünhet a feladatok válaszadási módjának egységesítése is. 


\section{A FONÉMATUDATOSSÁG TESZT VIZSGÁLATA AZ ÁLTALÁNOS ISKOLA ELSÖ}

ÉVFOLYAMOS TANULÓINAK KÖRÉBEN

\section{1. Módszerek}

\section{1. 1. Minta}

A 2016-os, első osztályos mintában 4342 tanuló szerepelt. A tanulók átlagéletkora 6,67 év (szórás=0,58 év). A minta 158 általános iskola 234 osztályának 2051 lány és 2185 fiú tanulójából állt. A tanulók nemére vonatkozóan 106 hiányzó adatunk van. A Központi Statisztikai Hivatal adatbázisának vonatkozó adatait áttekintve regionális és megyei szintü összehasonlítást végeztünk. A 2016-os tanévben az általános iskola első osztályos tanulóinak, illetve a mintában szereplő tanulók regionális eloszlását az 32. ábra tartalmazza, míg a lány és fiú tanulók eloszlását az 33. és 34. ábra jeleníti meg. A hét régió közül Dél- és Nyugat-Dunántúl, valamint Észak-Magyarország esetében a minta eloszlása megközelíti az országos eloszlást. A minta Közép- Magyarország esetében alul, míg Közép-Magyarország, Észak- és Dél- Alföld esetében felülreprezentált. A minta regionális eloszlásának nemek szerinti bontása esetében lány tanulók alulreprezentáltsága jelenik meg Közép-Magyarország, míg felülreprezentáltsága Közép-Dunántúl, Észak- és Dél-Alföld esetében. A lány tanulók eloszlása Nyugat- és DélDunántúl, valamint Észak-Magyarország esetében közelíti meg az országos eloszlás mértékét. A fiúk esetében közel azonos kép rajzolódik ki, mint a lány tanulók esetében. A fiú tanulók alulreprezentáltnak Közép-Magyarország, felülreprezentáltnak Közép-Dunántúl, Észak- és Dél- Alföld esetében tekinthetők. A többi régió esetében (Nyugat- és Dél- Dunántúl, valamint Észak-Magyarország) a mintában szereplő fiú tanulók eloszlása megközelítette az országos fiú tanulók eloszlásának arányát. A régiónkénti vizsgálatok illeszkedésvizsgálata alapján nem tapasztaltunk különbséget sem a teljes minta $\left(\chi^{2}=56,00 \mathrm{df}=49, \mathrm{p}>0,05\right)$, sem a lány $\left(\chi^{2}=56,00\right.$ $\mathrm{df}=49, \mathrm{p}>0,05)$, sem a fiú tanulók $\left(\chi^{2}=56,00 \mathrm{df}=49, \mathrm{p}>0,05\right)$ esetében. 


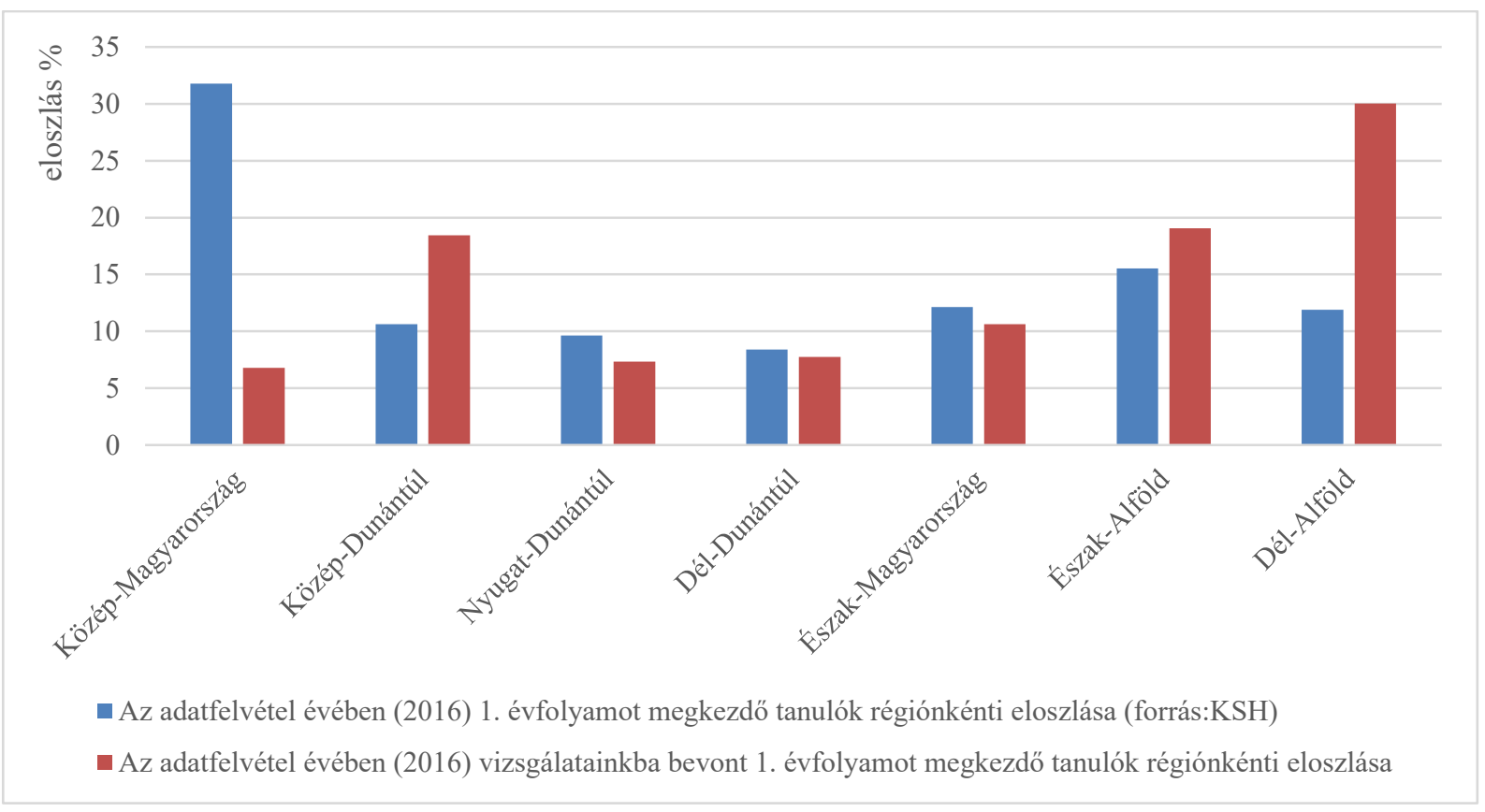

32. ábra

Az adatfelvétel évében (2016) 1. évfolyamot megkezdö tanulók, valamint a vizsgálatainkba bevont minta regionális eloszlása

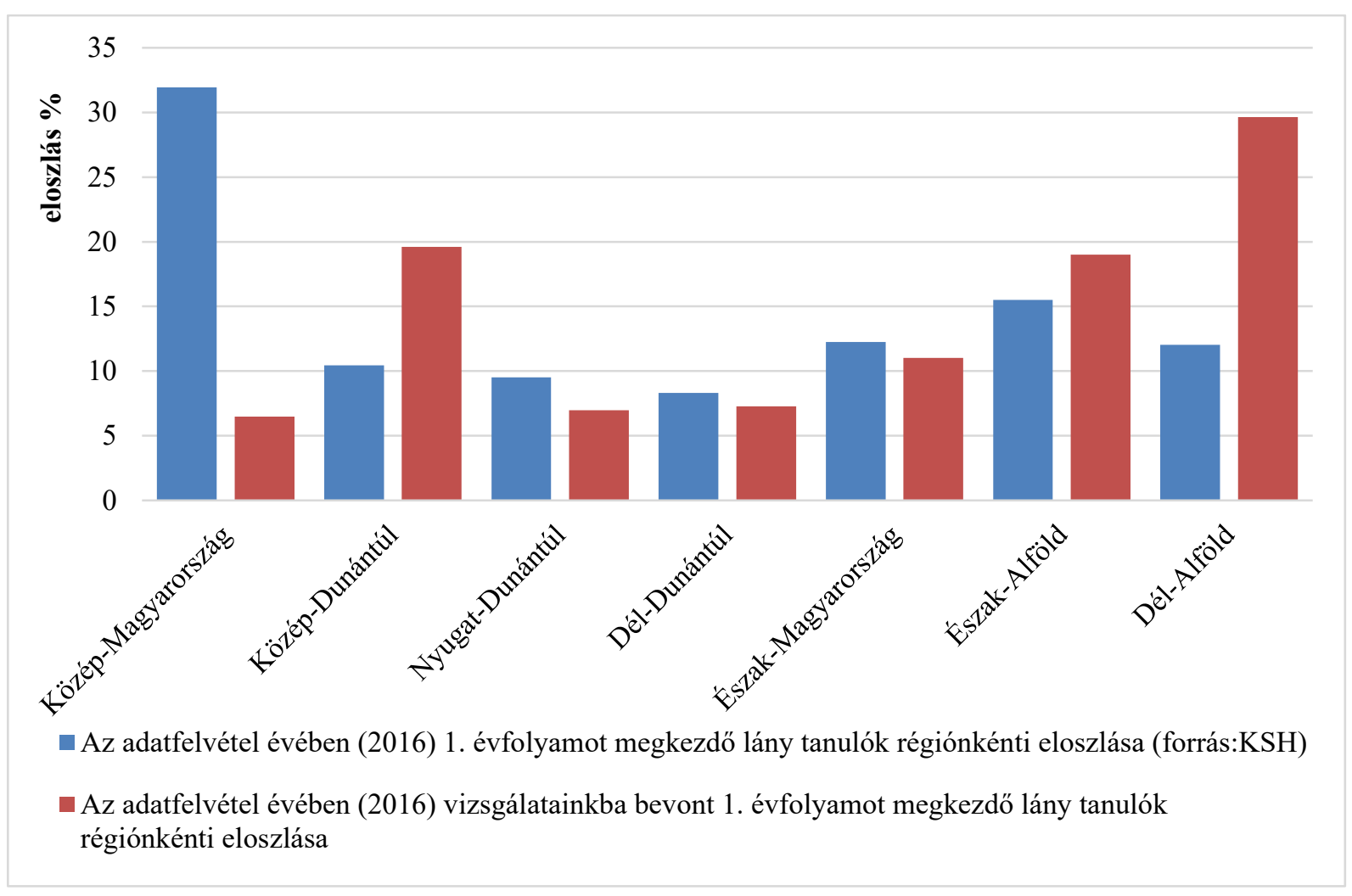

33. ábra

Az adatfelvétel évében (2016) 1. évfolyamot megkezdö lány tanulók, valamint a vizsgálatainkba bevont lány tanulók regionális eloszlása 


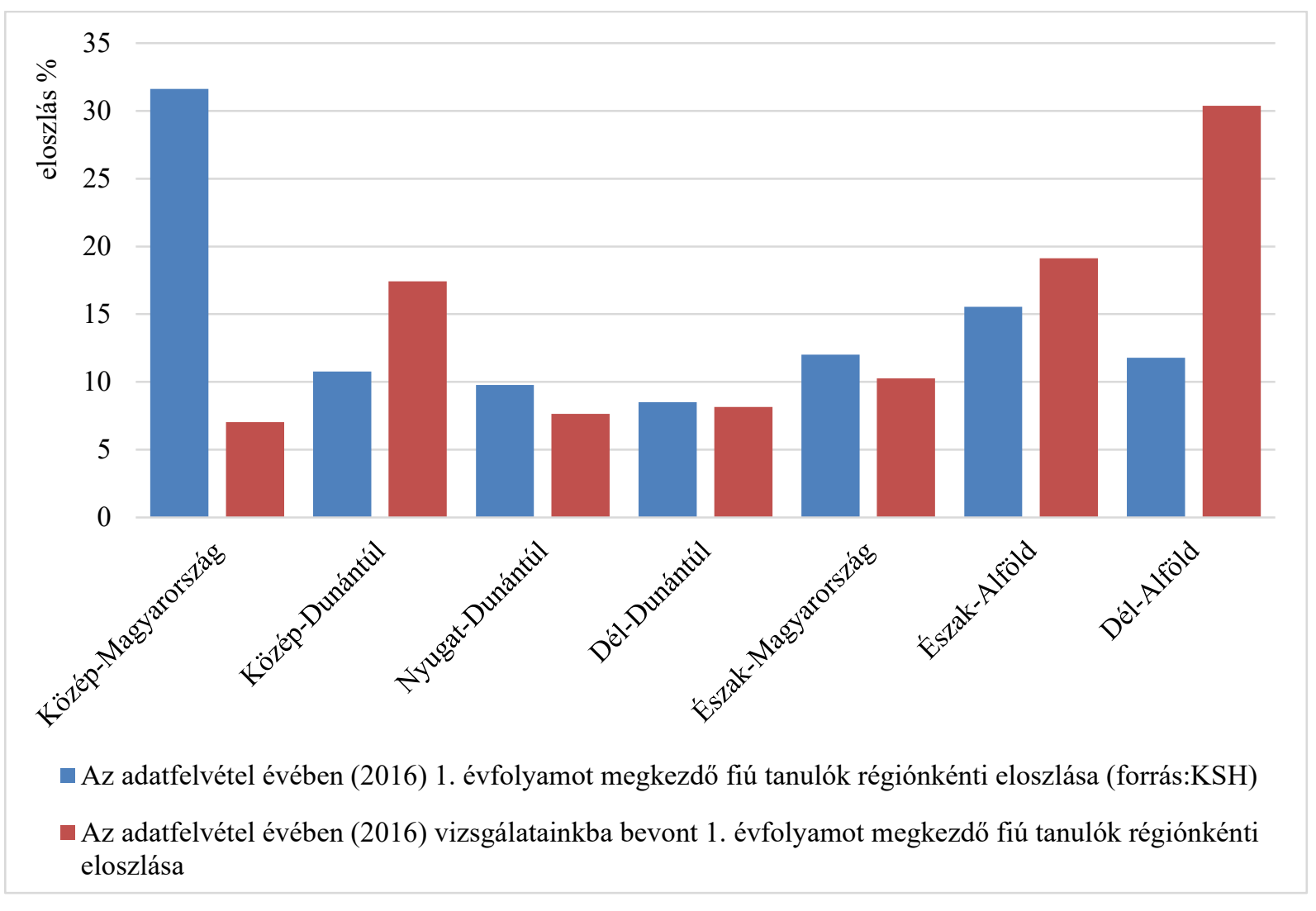

\section{4. ábra}

Az adatfelvétel évében (2016) 1. évfolyamot megkezdö fiú tanulók, valamint a vizsgálatainkba bevont fiú tanulók regionális eloszlása

A régiónkénti eloszlás után a megyénkénti eloszlást is vizsgáltuk. Mivel mind Budapest, mind Pest megye szerepeltette magát a mintában, ezért a fővárost és az öt magába foglaló megyét külön egységként kezeltük. A 2016-ban első osztályt kezdett, valamint a mintában szereplő tanulók megyénkénti eloszlását az 35. ábra tartalmazza, míg a nemenkénti elkülönítést a 36. és 37. ábra jeleníti meg. A 35. ábráról leolvasható, hogy Budapest és Pest megye alulreprezentáltsága a legerősebb. Felülreprezentáltnak tekinthető Fejér, Komárom-Esztergom, Jász-Nagykun-Szolnok, Békés és Csongrád megye. A lányok (36. ábra) és fiúk (37. ábra) esetében is egyaránt esetében az alulreprezentált a főváros, valamint Pest, Veszprém és Szabolcs-Szatmár-Bereg megye. A megyék szerinti eloszlás vizsgálata során sem tapasztaltunk különbséget sem a teljes minta $\left(\chi^{2}=420,00 \mathrm{df}=400 \mathrm{p}>0,05\right)$, sem a lányok $\left(\chi^{2}=399,00 \mathrm{df}=380\right.$ $\mathrm{p}>0,05)$, sem a fiúk $\left(\chi^{2}=399,00 \mathrm{df}=380\right.$ p>0,05) eloszlásának tekintetében. 


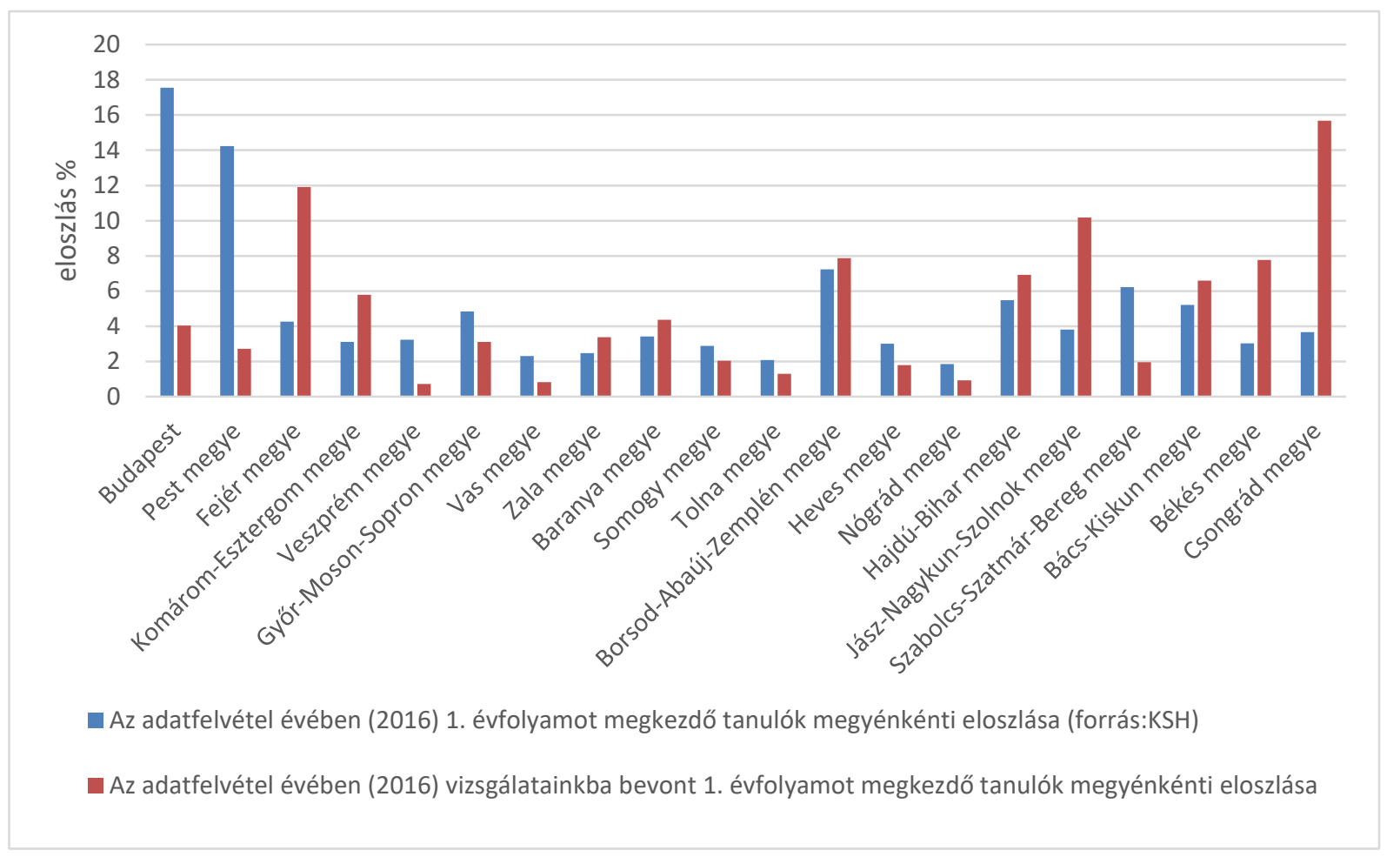

35. ábra

Az adatfelvétel évében (2016) 1. évfolyamot megkezdö tanulók, valamint a vizsgálatainkba bevont minta megyénkénti eloszlása

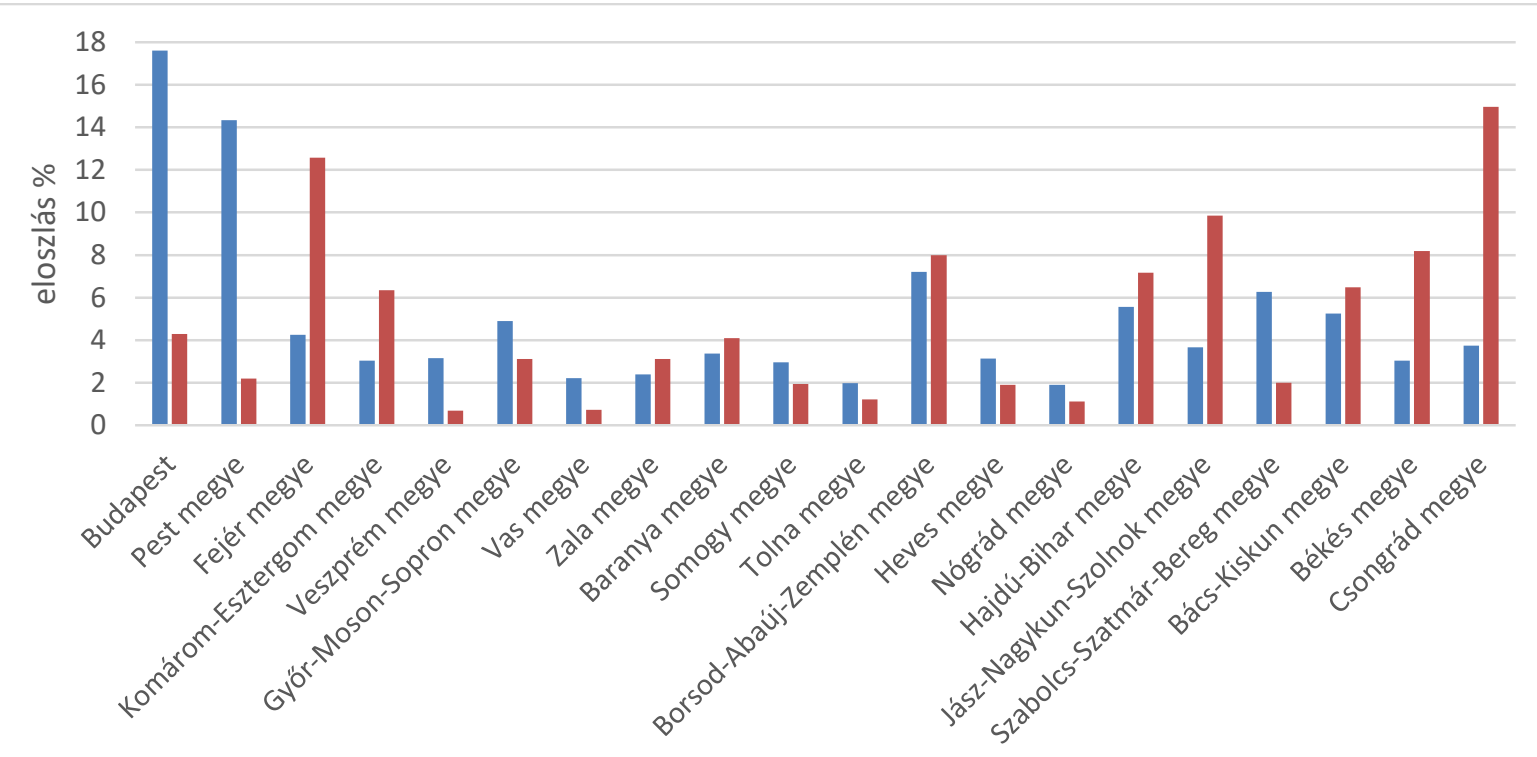

— Az adatfelvétel évében (2016) 1. évfolyamot megkezdő lány tanulók megyénkénti eloszlása (forrás:KSH)

— Az adatfelvétel évében (2016) vizsgálatainkba bevont 1. évfolyamot megkezdő lány tanulók megyénkénti eloszlása

36. ábra

Az adatfelvétel évében (2016) 1. évfolyamot megkezdö lány tanulók, valamint a vizsgálatainkba bevont lány tanulók megyénkénti eloszlása 


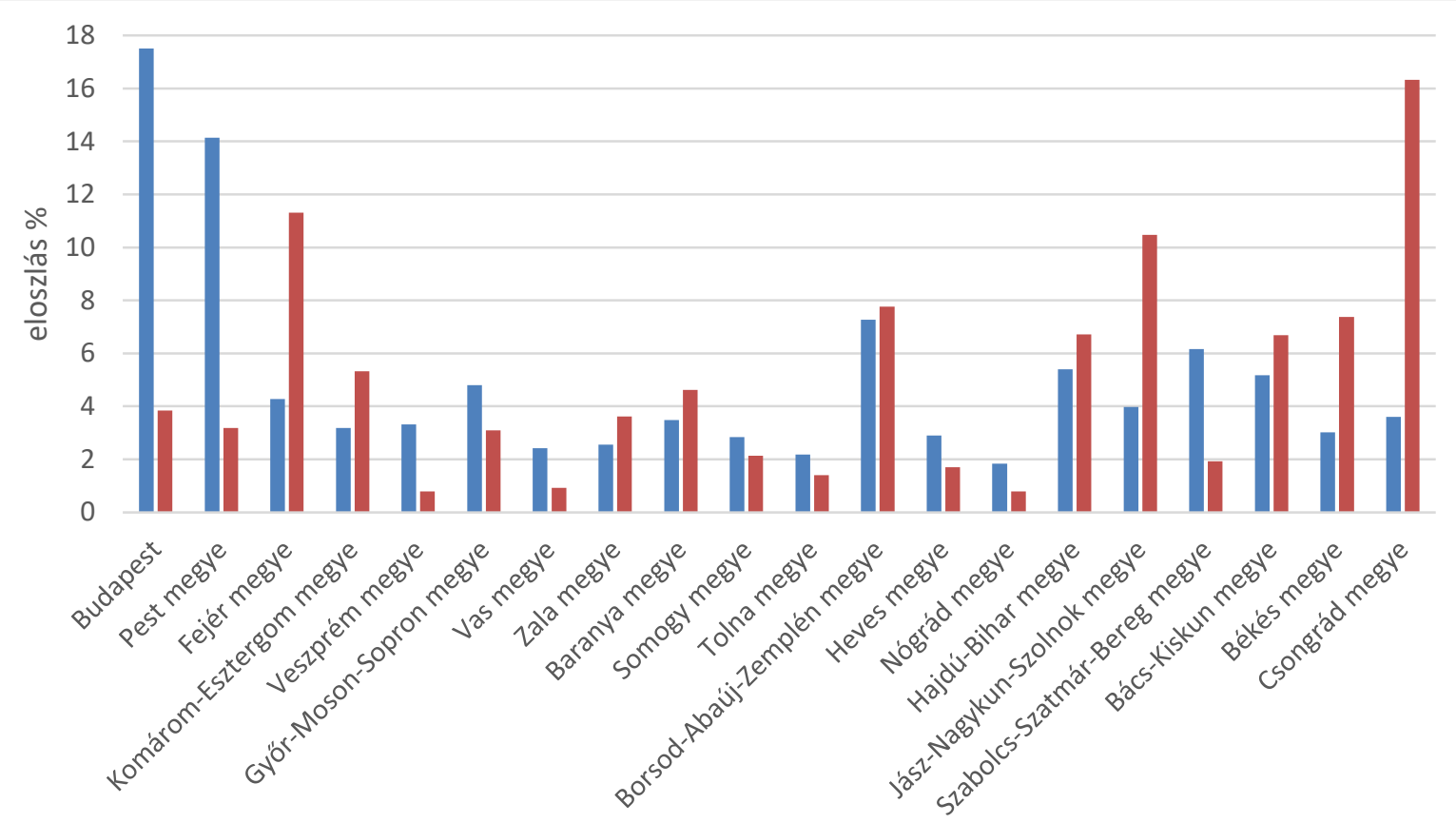

— Az adatfelvétel évében (2016) 1. évfolyamot megkezdő fiú tanulók megyénkénti eloszlása (forrás:KSH)

— Az adatfelvétel évében (2016) vizsgálatainkba bevont 1. évfolyamot megkezdő fiú tanulók megyénkénti eloszlása

\section{7. ábra}

Az adatfelvétel évében (2016) 1. évfolyamot megkezdö fiú tanulók, valamint a vizsgálatainkba bevont fiú tanulók megyénkénti eloszlása

\section{1. 2. A mérőeszköz}

A mérőeszköz, a 2015-ös őszi mérés tapasztalatai után, 2016 őszén rövidített formában került felvételre. Ennek oka kettős volt: egyrészt a fonológiai tudatosságot mérő teszt az iskolakészültségi mérőeszköz-csomag, a matematikatanulás-előfeltételeit vizsgáló résztesztjével, 45 perces tanóra keretein belül, ugyanazon alkalommal került felvételre, másrészt pedig a 2015-ös mérés eredményei arra engedtek következtetni, hogy a vizsgált korcsoport esetében nem a nyelvi egység mérete a fő differenciáló erő a feladatok és a képességstruktúra terén, és nem is ez a tényező határozza meg a teszt belső konstruktumát, hanem a müveleti szint. Ezen tapasztalatok, illetve azon szempont alapján, hogy a gyermekek iskolakészültségi tesztje is fonéma szintű műveletvégzést kíván meg az első osztályba lépő korosztálytól, a szótag szintű feladatokat eltávolítottuk a mérőeszközből.

A tesztben a másik lényeges változtatás, a szegmentálás feladattípus esetében történt. A szegmentálás müveletét kérő feladatok elkülönültek a 2015-ös mérés személy- és itemtérképe alapján is, valamint ez volt az egyetlen feladat a 2015-ös adatfelvétel esetében, mely a drag and 
drop, tehát a vonszolás müveletét kérte a gyermekektől. Jelen adatfelvétel esetében a feladat megjelenési formáját úgy módosítottuk, hogy a válaszadás formája (a tesztben szereplő többi feladathoz hasonlóan) kattintás legyen. A mérőeszköz feladattípusai tartalmi szempontból megfeleltethetők a 2015-ös mérés vonatkozó feladatainak, ugyanazon példaanyaggal dolgoznak. A szótagszintü feladatok eltávolításával a fonématudatosság teszt 40 itemből állt (29. táblázat). A mérőeszköz túlnyomó részében (25 item) az azonosításhoz köthető feladatok jelentek meg, míg a hangokkal történő manipuláció műveleteit (szintézis, szegmentálás, törlés) vizsgáló részt 15 item alkotta.

29. táblázat. A fonématudatosság teszt felépitése

\begin{tabular}{ccc}
\hline Részterület & Feladattípus & Itemszám \\
\hline Fonématudatosság & Fonémaazonosítás & 10 \\
& $\begin{array}{c}\text { Fonémaazonosítás a hívóhang } \\
\text { helyének meghatározásával } \\
\text { Szókezdő hang azonosítása }\end{array}$ & 10 \\
& Fonémaszegmentálás & 5 \\
& Fonémaszintézis & 5 \\
& Fonémaszegmentálás & 5 \\
& Fonématörlés & 5 \\
\hline Teljes teszt & & 5 \\
\hline
\end{tabular}

A feladatok megjelenési formáit az 5. 1. 2. fejezetben szereplő az 18-23. ábra, valamint a 2015-ös adatfelvétel és a 2016-os adatfelvétel között módosult feladattípust az 38. és 39. ábra szemlélteti. A feladat módosítása során látszik, hogy az első esetben a válaszadás a bábu, Robi robot megfelelő mezőre való húzásával történt, míg a módosított esetben annyi sziromra kell kattintania a tanulónak, ahány hangot hall a szóban. A kattintás sorrendje, és eloszlása teljesen opcionális, a válasz helyességének megállapításához a kattintások számát vettük figyelembe. 


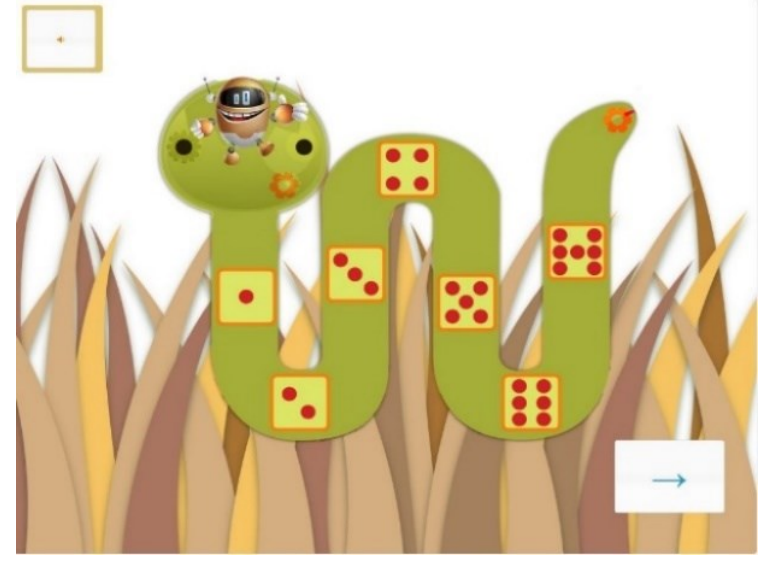

9. ábra - Példafeladat a fonémaszegmentálás feladat megjelenitési formájára

[Társasjátékot fogunk játszani. Szavakat fogsz hallani. Lépj annyit Robi robottal, ahány hangot hallasz a szóban! fa]

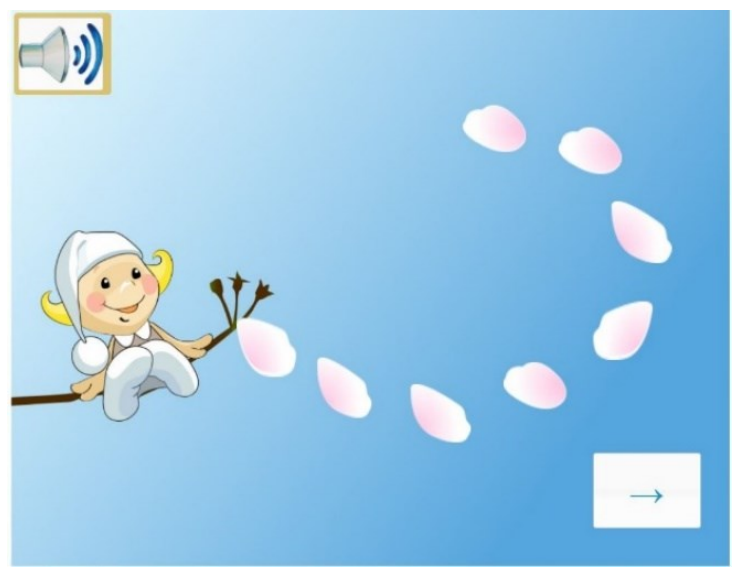

39. ábra - Példafeladat a módositott fonémaszegmentálás feladat megjelenitési formájára

[Szavakat fogsz hallani! Kattints annyi sziromra, ahány hangot hallasz a szóban! füge] 


\section{1. 3. Eljárás}

Az adatfelvétel módja jelentősen hasonlít a 2015-ös mérés esetén alkalmazottal, hiszen a tanulók ugyanúgy asztali számítógépek (PC-k) segítségével, pedagógusaik felügyeletével és elökészületével oldották meg a teszteket. A tanulók minden esetben, külön tanóra keretén belül, a géphasználat teszttel kezdtek, mely az előző adatfelvételhez képest több itemet és és változatosabb feladattípusokat tartalmazott. Míg az előző adatfelvétel esetében a fonológiai tudatosság teszt kitöltésére egy tanóra állt a tanulók rendelkezésére, jelen esetben a matematikatanulás előfeltétel-készségei teszttel együtt történt a fonématudatosság teszt, majd egy másik tanóra keretein belül az induktív gondolkodás, vizuális memória és feladattartás tesztsorok rögzítése (6. melléklet). Mivel a géphasználat és a fonématudatosság teszt felvétele külön alkalommal történt, illetve fontosnak tartottuk azt is, hogy a tanulók ne rögtön a fonématudatosságot vizsgáló teszt első feladatát oldják meg az azonosító oldalról történő továbblépés után, ezért néhány, a kattintás müveletének gyakorlására, ismétlésére vonatkozó játékos ismétlőfeladatot kaptak, mely a teszten elért teljesítménybe nem számított bele.

\section{2. Eredmények}

\section{2. 1. A mérőeszköz megbízhatóságának vizsgálata}

A teljes teszt és a feladattípusok itemszámait, megbízhatósági mutatóit, valamint a mintaelemszámokat a 30. táblázat foglalja össze. A teljes teszt megbízhatósága magas értéket mutat (Cronbach- $\alpha=0,90)$. A feladattípusok megbízhatósági mutatóinak vizsgálata során viszont kiemelkedően alacsony a szótagtörlés részteszt megbízhatósága, mely 5, és a fonémaazonosítás feladattípusé, mely 10 itemes szubtesztből állt. Amennyiben a feladatokat a müveleti szintek szerint (szintézis, szegmentálás, törlés, azonosítás) különítjük el, 0,80-hoz közelítő Cronbach- $\alpha$ értékeket kapunk. A szintézis, szegmentálás és törlés müveleti tagolódásának értékei megegyeznek az egyes feladattípusok értékeivel, de a könnyebb átláthatóság érdekében újra, a műveleti szintü tagolódásánál is közöltük őket. A tesztbe összesen 4342 gyermek lépett be, közülük 4 tanuló az első résztesztet sem fejezte be. Az első részteszt így 4338 érvényes adattal rendelkezik, a teljes tesztre vonatkozóan 4308 érvényes kitöltés érkezett. 
30. táblázat. A fonématudatosság teljes tesztjének és résztesztjeinek reliabilitás mutatói (Cronbach- $\alpha$ )

\begin{tabular}{cccc}
\hline Feladattípus & Itemek száma & Cronbach- $\alpha$ & $\mathrm{N}$ \\
\hline Fonémaazonosítás & 10 & 0,58 & 4338 \\
$\begin{array}{c}\text { Fonémaazonosítás a hívóhang } \\
\text { helyének meghatározásával }\end{array}$ & 10 & 0,79 & 4331 \\
Fonémaszegmentálás & 5 & 0,76 & 4326 \\
Szókezdő hang azonosítása & 5 & 0,70 & 4321 \\
Fonémaszintézis & 5 & 0,75 & 4317 \\
Fonématörlés & 5 & 0,76 & 4308 \\
\hline Azonosítás & 25 & 0,84 & 4321 \\
Szintézis & 5 & 0,75 & 4317 \\
Szegmentálás & 5 & 0,76 & 4326 \\
Törlés & 5 & 0,76 & 4308 \\
\hline Teljes teszt & $\mathbf{4 0}$ & $\mathbf{0 , 9 0}$ & $\mathbf{4 3 0 8}$ \\
\hline
\end{tabular}

Mivel a résztesztek reliabilitásmutatói közti különbség jelentős, ezért indokoltnak találtuk az itemek elkülönítés mutatóinak vizsgálatát (40. ábra). A kapott értékek alapján 3 item rendelkezik 0,3 alatti értékkel. Mindhárom item a fonémaazonosítás feladattípusból került ki. Ezen itemek nem képezik a további elemzések részét, tesztből való eltávolításuk bár az összteszt reliabilitását csak kis mértékben növeli, a fonémaazonosítás részteszt esetében jelentős javulást eredményez. A tesztben szereplő további 37 item eléri vagy meghaladja a 0,3as teszt-item korrelációs értéket. Az itemek közti korrelációk értékeit az 5. melléklet tartalmazza. A teszt kitöltésének átlagos ideje 13,09 perc (szórás=4,76), mely, a vonatkozó rövidítés és a szegmentálás feladat átalakítása után megfelel az előzetes elvárásoknak, a tanulók számára könnyen teljesíthetö. 


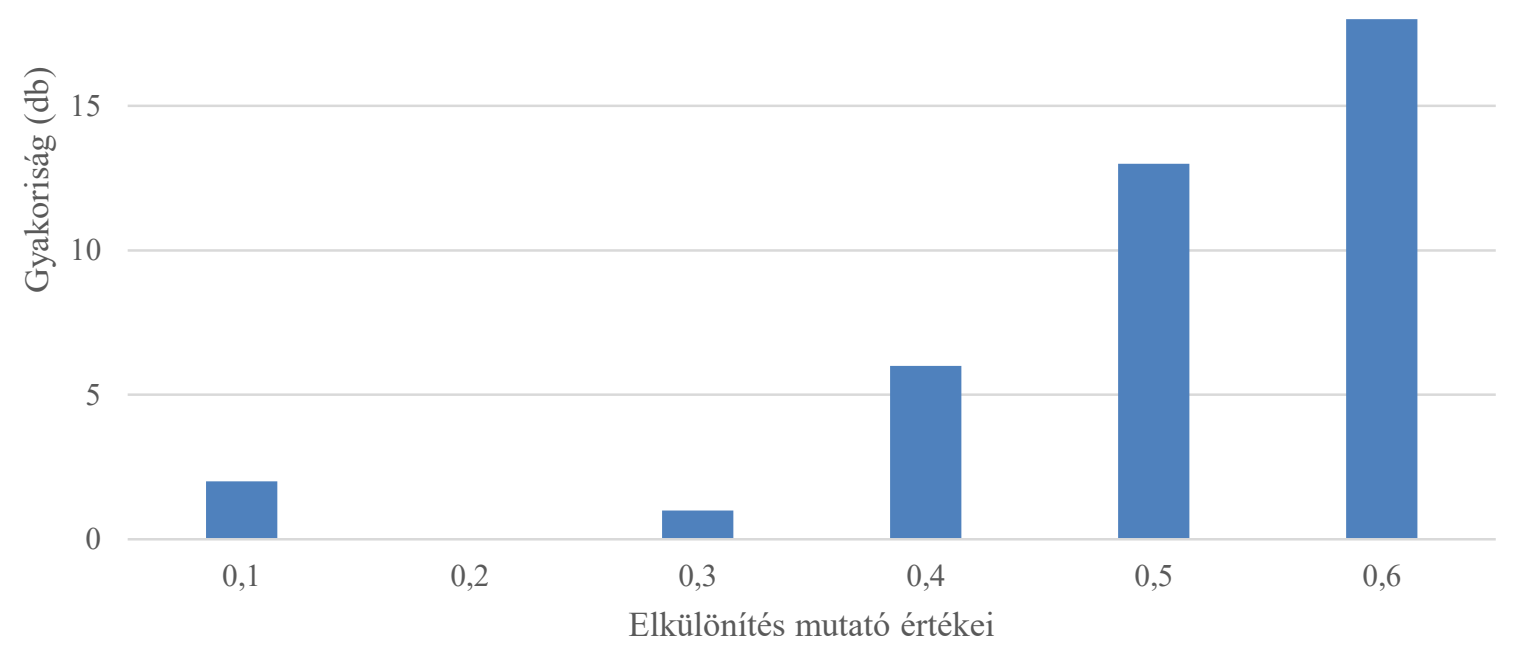

40. ábra

Az itemek elkülönités mutatóinak eloszlási gyakorisága az első osztályos fonématudatossági teszt esetében

31. táblázat. Az elkülönités mutatók figyelembe vételével módositott fonématudatosság teszt felépitése, a teljes teszt és a résztesztek reliabilitás mutatói (Cronbach- $\alpha$ )

\begin{tabular}{cccc}
\hline Feladattípus & Itemek száma & Cronbach- $\alpha$ & $\mathrm{N}$ \\
\hline $\begin{array}{c}\text { Fonémaazonosítás } \\
\text { Fonémaazonosítás a hívóhang helyének } \\
\text { meghatározásával }\end{array}$ & 7 & 0,67 & 4338 \\
Fonémaszegmentálás & 10 & 0,79 & 4331 \\
Szókezdő hang azonosítása & 5 & 0,76 & 4326 \\
Fonémaszintézis & 5 & 0,70 & 4321 \\
Fonématörlés & 5 & 0,75 & 4317 \\
\hline Azonosítás & 5 & 0,76 & 4308 \\
Szintézis & 22 & 0,86 & 4321 \\
Szegmentálás & 5 & 0,75 & 4317 \\
Törlés & 5 & 0,76 & 4326 \\
Teljes teszt & 5 & 0,76 & 4308 \\
\hline
\end{tabular}




\section{2. 2. A feladatok nehézségi, és a tanulók képességszintjének feltárása}

Az itemek müködéséről további információt nyújthat a valószínűségi tesztelmélet alkalmazása. Az EAP/PV reliabilitás mutató értéke 0,89. Az 41. ábra személy-item térképén látható minden X 28,9 tanulót reprezentál. Az ábra jobb oldala tükrözi az itemnehézségi skálát, a bal oldala pedig a tanulókra vonatkoztatható képességskálát. Az itemek áttekinthetőségét színek segítik. A fonémaazonosítást kék (1-17 és 23-27), a fonémaszegmentálást türkiz (1822), a fonématörlést sötétzöld (33-37), a fonémaszintézist szürke (28-32). Az itemek a képességskála széles tartományát lefedik, -1,537 és 2,931 itemnehézségi szint közt helyezkednek el. A szegmentálás müveletét magába foglaló feladatok az 0,934 és 2,931-es logitértékek között helyezkednek el, ezzel kijelenthető, hogy ezen feladatok bár széles intervallumban helyezkednek el, mégis a tanulók számára nehéznek tekinthetők. Az azonosítást kérő feladatok vegyülnek a szegmentálást kérő feladatokkal a 0,819 és -0,048 közti intervallumban, csupán egyet feladat különül el jelentősen a többitől, melyhez az -1,177-es logitérték tartozik. Ez a feladat tehát könnyebbnek bizonyult a tanulók számára, mint a többi azonosítást kérő feladat. A -0,287, 1,537 közötti intervallumban keverednek a törlés és a szintézis müveletét kérő feladatok. Köztük kap helyet az előbb említett azonosítási feladat is. Az itemnehézségi skála szerint tehát az egyes feladattípusok vegyes képet mutatnak. Egyetlen item kivételével viszont megállapítható, hogy a 0 képességszint körül, illetve a felett helyezkednek el az azonosítást és szegmentálást kérő feladatok, míg a 0 képességszint alatt a szintézist és törlést kérő itemtípusok. 
1 $\operatorname{xxxxx|}$

$\operatorname{xxxxxxx|10} 11$

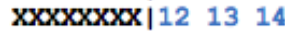

$\operatorname{xxxxxxxxx} \mid 4 \quad 17$

$\begin{array}{lllll}X X X X X X X X \mid 2 & 18 & 20 & 26\end{array}$

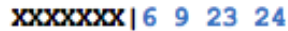

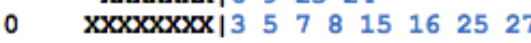

$\operatorname{xxxxxxxx}$

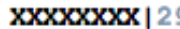

$\operatorname{xxxxxxxxx|}$

$\operatorname{xxxxxx} \mid 36$

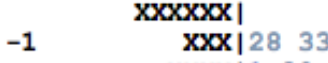

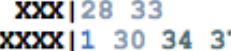

$\mathbf{x x x} \mid 35$

$\mathbf{x x} \mid 3132$

xx|

$\mathbf{x x}$

$-2$

$\mathbf{x} \mid$

$\mathbf{x} \mid$

$\mathbf{x}$ |

$\mathbf{x} \mid$

$-3$

$\begin{array}{lll}-3 & 1 \\ & -4 & 1 \\ & 1 \\ & & 1 \\ & & 1\end{array}$

41. ábra

Az elsö osztályos fonématudatosság teszt személy-item térképe.

A fonémaazonositást a kék, a fonémaszegmentálást a türkiz, a fonématörlést a sötétzöld, a fonémaszintézist a szürke szinek jelölik. 


\section{2. 3. A fonématudatosság teszt belső konstruktumának vizsgálata}

A teszt belső konstruktumának vizsgálatához a résztesztek közti korrelációk feltárását alkalmaztuk. A korrelációk vizsgálata során elsőként a müveleteket vettük alapul, tehát az azonosítás, szintézis, szegmentálás és törlés müveletét (ezen müveletek, mivel csak a fonéma szintü feladatok szerepeltek a tesztben megegyeznek a vonatkozó résztesztek értékeivel). Vizsgáltuk az említett műveletek teljes teszttel való kapcsolatát, majd az azonosítás különböző feladattípusainak egymás közti és a teljes teszttel alkotott kapcsolatát. A teljes teszt és az azonosítás müvelete között erős, függő kapcsolat áll fenn, ami nem meglepő, hiszen a feladatok zömét az azonosítás műveletéhez kapcsolódó feladattípusok teszik ki (25 item). A szegmentálás és a törlés esetében a teljes teszttel közepes, míg a szintézis feladatok és az összteszt között magas korreláció jelentkezik. A müveletek és a teljes teszt között minden esetben közepes erősségü kapcsolat áll fenn. A müveletek egymás közti kapcsolata a szegmentálás és törlés kapcsolatát kivéve közepes erősségü, a szegmentálás és a törlés között gyenge kapcsolat jelentkezett (32. táblázat).

32. táblázat. A feladattípusok egymásközti, valamint a feladattípusok és a teljes teszt közti korrelációs együtthatók

\begin{tabular}{cccccccc}
\hline & F_Az & F_Hh & F_Szeg & F_Szh & F_Szin & F_Tor & F_Az \\
\hline F_Hh & 0,55 & & & & & & \\
F_Szeg & 0,40 & 0,49 & & & & & \\
F_Szh & 0,42 & 0,51 & 0,50 & & & & \\
F_Szin & 0,39 & 0,46 & 0,42 & 0,48 & & & \\
F_Tor & 0,35 & 0,43 & 0,29 & 0,40 & 0,59 & & \\
F_Az & 0,79 & 0,90 & 0,56 & 0,74 & 0,54 & 0,49 & \\
\hline Teljes teszt & 0,73 & 0,84 & 0,69 & 0,74 & 0,72 & 0,66 & 0,95 \\
\hline Megjegyzés: minden & korreláció & p<0,01 szinten szignifikáns; F_Szh: szókezdó hang azonosítása; $F_{\text {S_Szeg: }}$ \\
fonémaszegmentálás; F_Tor: fonématörlés; F_szin: fonémaszintézis; F_Az: fonémaazonositás; F_Hh: & Fonémaazonositás a hivóhang helyének meghatározásával
\end{tabular}

\section{2. 4. A tanulók teszten elért teljesítményének vizsgálata}

A tanulók teszten nyújtott átlagteljesítményét és annak szórását az 33. táblázat mutatja be. A teljes teszten elért átlagos teljesítmény 53,87\%pont, ami szinte megegyezik a pszichometrikailag kívánatos 50\%-kal. Az összteszt szórása 23,18\%pont, ami rámutat a tanulók közötti nagy különbségekre. A táblázatban szereplő átlagteljesítmény alapján látható, hogy a fonématörlés, és a fonémaszintézis feladatokon magasabb, míg a szegmentálás feladatokon a legalacsonyabb átlagteljesítmény tapasztalható. A legmagasabb szórás értékkel $(33,64 \%)$ a 
szókezdő hang azonosítása feladattípus rendelkezik, tehát ezen adatok alapján ez a feladat differenciálta leginkább a tanulókat, az egyéni különbségek ebben az esetben a legszembetűnőbbek.

33. táblázat. A tanulók fonématudatosság teszten nyújtott teljesitményének átlaga és szórása

\begin{tabular}{ccccc}
\hline Feladattípus & $\begin{array}{c}\text { Itemek } \\
\text { száma }\end{array}$ & $\begin{array}{c}\text { Átlag } \\
\%\end{array}$ & $\begin{array}{c}\text { Szórás } \\
\%\end{array}$ & $\mathrm{~N}$ \\
\hline Fonémaazonosítás & 7 & 55,12 & 28,30 & 4338 \\
Fonémaazonosítás a hívóhang & 10 & 47,05 & 28,93 & 4331 \\
helyének meghatározásával & & 52,24 & 33,64 & 4326 \\
Szókezdő hang azonosítása & 5 & 73,43 & 30,65 & 4321 \\
Fonémaszintézis & 5 & 32,82 & 32,15 & 4317 \\
Fonémaszegmentálás & 5 & 74,13 & 31,08 & 4308 \\
Fonématörlés & 5 & $\mathbf{5 3 , 8 7}$ & $\mathbf{2 3 , 1 8}$ & $\mathbf{4 3 0 8}$ \\
\hline Teljes teszt & $\mathbf{3 7}$ & & &
\end{tabular}

A tanulók képességeinek árnyaltabb feltárását szolgálja a teljes és a részteszteken nyújtott teljesítmények eloszlásának vizsgálata (34. táblázat). A Kolmogorov-Smirnov teszt szerint minden eloszlás szignifikánsan eltér a normál eloszlástól. Az eloszlások jobbra asszimetrikusak a fonémaazonnosítás, a szókezdő hang azonosítása, a fonémaszintézis, a fonématörlés résztesztek és a teljes teszt esetében is, tehát ezeken a részteszteken a normál eloszláshoz képest több tanuló ért el magasabb teljesítményt. Az eloszlások lapultabbak a fonémaazonosítás, a fonémaazonosítás a hívóhang helyének meghatározásával, a szókezdő hangazonosítása, a fonémaszegmentálás és a teljes teszt esetében, azaz a normál eloszláshoz képest alacsonyabb és egyenletesebb eloszlású volt a tanulók teljesítménye.

34. táblázat. A teljes fonématudatosság teszt és a résztesztek eloszlásainak statisztikai mutatói

\begin{tabular}{|c|c|c|c|c|c|}
\hline Teszt megnevezése & $\begin{array}{c}\text { skewness } \\
\text { (szimmetria) }\end{array}$ & $\begin{array}{c}\text { kurtosis } \\
\text { (lapultság) }\end{array}$ & $\begin{array}{l}\text { Kolmogorov- } \\
\text { Szmirnov teszt }\end{array}$ & $d f$ & $p$ \\
\hline $\begin{array}{l}\text { Fonémaazonosítás } \\
\text { Fonémaazonosítás a }\end{array}$ & $-0,109$ & $-1,085$ & 0,145 & 4317 & $<0,01$ \\
\hline $\begin{array}{l}\text { hívóhang helyének } \\
\text { meghatározásával }\end{array}$ & 0,242 & $-0,989$ & 0,124 & 4317 & $<0,01$ \\
\hline $\begin{array}{l}\text { Szókezdő hang } \\
\text { azonosítása }\end{array}$ & $-0,135$ & $-1,180$ & 0,140 & 4317 & $<0,01$ \\
\hline Fonémaszintézis & $-1,046$ & 0,031 & 0,234 & 4317 & $<0,01$ \\
\hline Fonémaszegmentálás & 0,640 & $-0,824$ & 0,205 & 4317 & $<0,01$ \\
\hline Fonématörlés & $-1,154$ & 0,237 & 0,254 & 4317 & $<0,01$ \\
\hline Teljes teszt & $-0,172$ & $-0,571$ & 0,041 & 4386 & $<0,01$ \\
\hline
\end{tabular}




\section{2. 5. A tanulók teljesítményének eloszlása az életkoruk és nemük szerint}

A nemek közti különbségek vizsgálata során elsőként a teljes teszt és a nem közti korrelációs értéket vizsgáltuk. A 2015-ös adatok elemzéséhez hasonlóan, az elemzések során a fiúkat az 1-es, míg a lányokat a 2-es változó jellemzi, így ha a korrelációs együttható értéke pozitív, akkor a lányok, ha negatív, akkor a fiúk teljesítménybeli előnyét jelzi. A teljes teszt és a nem közötti korrelációs együttható értéke $r=0,06$, az összefüggés szignifikáns $(\mathrm{p}<0,01)$. Mivel a korreláció pozitív értékü, ezért kijelenthető, hogy az összteljesítmény tekintetében a lányok szignifikánsan jobban teljesítettek, mint a fiúk. Az összteszttel való összefüggésen kívül vizsgáltuk a müveletek, valamint a résztesztek közti összefüggéseket is. A müveletek a szintézis, szegmentálás és törlés esetében megegyeznek a vonatkozó résztesztekkel, hiszen jelen teszt csak fonéma szintü feladatokkal dolgozik. Egyedül az azonosítás müvelet esetében kerültek összevonásra a fonémaazonosítás, a fonémaazonosítás a hang helyének meghatározásával, illetve a szókezdő hang azonosítását kérő résztesztek. A műveletek és résztesztek nemekkel való kapcsolatának vizsgálata esetében mind esetben szignifikáns különbséget találtunk, mely minden esetben a lányok előnyét bizonyítja. A korrelációs együtthatók értékeit a vonatkozó szignifikancia értékkel és a mintaelemszámával az 35. táblázat tartalmazza, míg a fonématudatosság fejlettségéről és a tanulók elért pontszámait az 36. táblázat tartalmazza. Bár a különbség minden esetben szignifikáns, mégis az elért \%pontok alapján ennek mértéke elhanyagolható.

35. táblázat. A nem és a résztesztek közti korrelációs együtthatók értékei, a vonatkozó szignifikancia értékek és a mintaelemszáma

\begin{tabular}{llcc}
\hline & nem & $\mathrm{p}$ & $\mathrm{N}$ \\
\hline $\begin{array}{l}\text { Fonémaazonosítás } \\
\text { Fonémaazonosítás a }\end{array}$ & $0,03^{*}$ & 0,02 & 4236 \\
hívóhang helyének & $0,04^{*}$ & 0,01 & 4233 \\
meghatározásával & & & \\
$\begin{array}{l}\text { Szókezdő hang } \\
\text { azonosítása }\end{array}$ & $0,06^{*}$ & 0,00 & 4219 \\
Fonémaszintézis & $0,07^{*}$ & 0,00 & 4216 \\
Fonémaszegmentálás & $0,05^{*}$ & 0,00 & 4226 \\
Fonématörlés & $0,03^{*}$ & 0,04 & 4213 \\
Azonosítás & $0,05^{*}$ & 0,00 & 4236 \\
\hline Teljes teszt & $\mathbf{0 , 0 6 *}$ & $\mathbf{0 , 0 0}$ & $\mathbf{4 2 3 6}$ \\
\hline
\end{tabular}




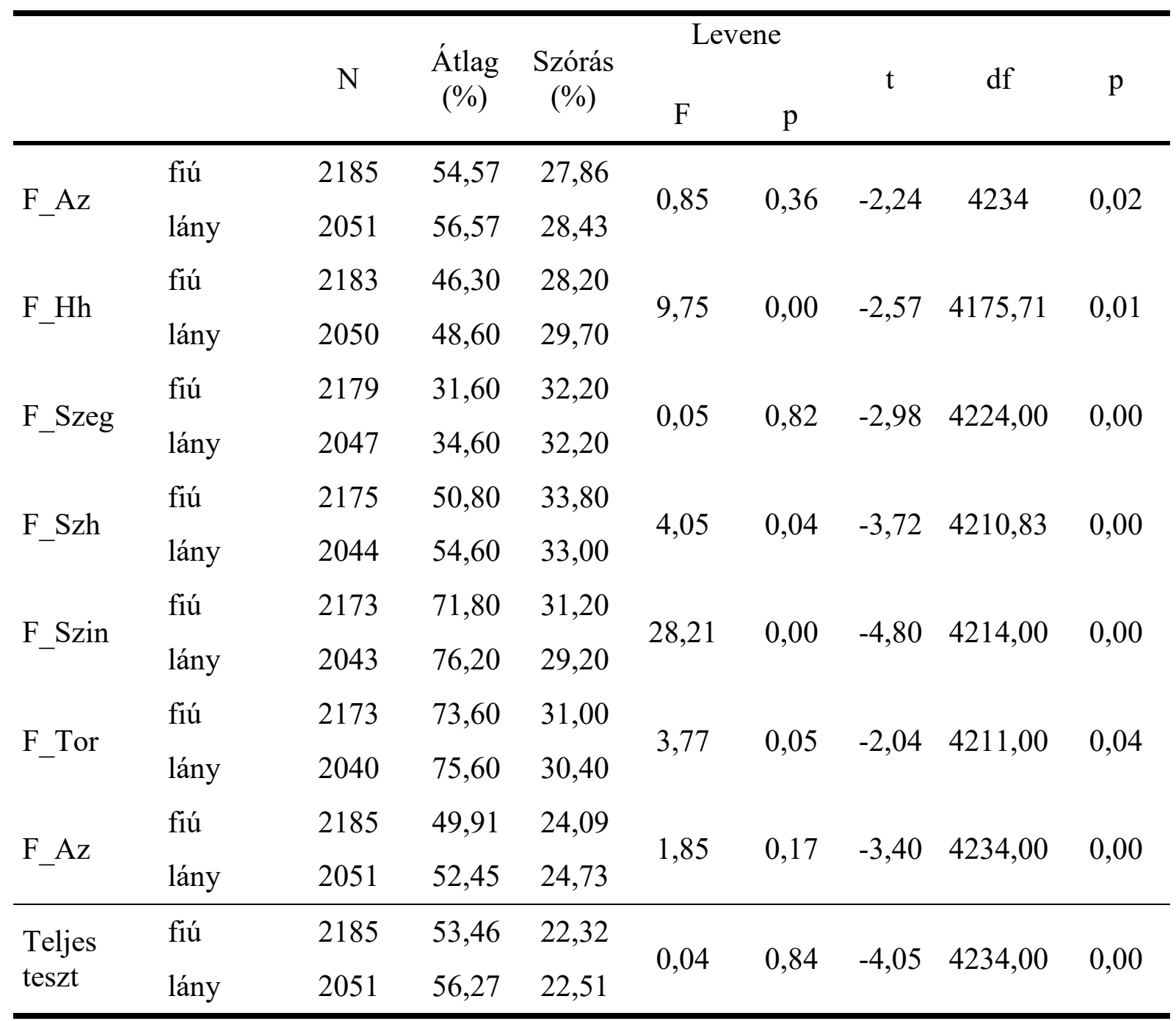

Megjegyzés: $F_{-}$Szh: szókezdö hang azonositása; $F_{-}$Szeg: fonémaszegmentálás; $F_{-}$Tor: fonématörlés; $F_{-}$szin: fonémaszintézis; $F_{-}$Az: fonémaazonositás; $F_{-}$Hh: fonémaazonositás a hivóhang helyének meghatározásával

A minta születési évenként történő bontása alapján 2007 és 2010 között született tanulók töltötték ki a tesztek, a minta elemszámához képest elenyésző számú, csupán 54 tanuló életkori adata hiányzik. A minta jellemzése során már megnéztük, hogy milyen átlagéletkor és szórás jellemezte az első osztályos gyermekeket, míg a korcsoportonkénti átlagéletkort és annak szórását a 37. táblázat tartalmazza.

37. táblázat. A tanulók átlagéletkora a fonématudatosság teszt rögzítésének idejében

\begin{tabular}{cccc}
\hline Születési év & Átlagéletkor (év) & Szórás (év) & N \\
\hline 2007 & 8,43 & 0,51 & 23 \\
2008 & 7,59 & 0,49 & 325 \\
2009 & 6,81 & 0,39 & 2865
\end{tabular}


A mintában legkevésbé a 2007-es születésű tanulók (23 tanuló), míg legnagyobb mértékben a 2009-ben született tanulók (2865 tanuló) képviseltetik magukat. A legjobb átlagteljesítményt a 2009-ben született tanulók értek el, a legnagyobb szórás érték pedig az első évfolyam legfiatalabb, a 2010-ben született tanulóihoz köthető (38. táblázat).

38. táblázat. A tanulók teljesitményének átlaga és szórása a születési év függvényében

\begin{tabular}{llll}
\hline Születési év & Átlag (\%) & Szórás (\%) & N \\
\hline 2007 & 51,00 & 21,97 & 23 \\
2008 & 46,62 & 21,24 & 325 \\
2009 & 55,35 & 22,46 & 2865 \\
2010 & 54,41 & 22,96 & 1075 \\
\hline
\end{tabular}

A születési év tekintetében szignifikáns különbség tapasztalható az életkor és az összteljesítmény tekintetében $(\mathrm{F}(4,4337)=11,16, \mathrm{p}<0,01)$, a 2009-ben és 2010-ben született gyermekek szignifikánsan jobban teljesítettek, mint a 2008-ban született tanulók. Hasonlóan a korábbi elemzéshez, a müveleti szintü és résztesztenkénti bontást is tanulmányoztuk. Minden esetben szignifikáns különbségeket találtunk az egyes korcsoportok között. Az azonosítás müveletének esetében $(F(4,4337)=14,03 p<0,01)$ a 2009-ben és 2010-ben született tanulók szignifikánsan jobban teljesítettek a 2008-ban születetteknél. Ugyanez a tendencia figyelhető meg a fonémaszegmentálás $(\mathrm{F}(4,4325)=4,11 \mathrm{p}<0,01)$, a fonémaazonosítás $(\mathrm{F}(4,4337)=8,32$ $\mathrm{p}<0,01)$, a fonémaazonosítás a hang helyének meghatározásával $(\mathrm{F}(4,4332)=8,56 \mathrm{p}<0,01)$, valamint a szókezdő hang azonosítását $(\mathrm{F}(4,4318)=12,72 \mathrm{p}<0,01)$ kérő feladattípusok esetében. A fonémaszintézis $(F(4,4315)=2,78 p<0,05)$ esetében szignifikáns különbség a 2008-as és 2009-es korosztály között jelentkezik, míg az a fonématörlés $(F(4,4312)=2,95$ p <0,05) esetében az ANOVA elemzés bár mutat szignifikáns különbséget, a Tukey’s-b post hoc teszt alapján ez nem egyértelmüsíthető.

Mivel az első osztályosok körében az adott születési év a készség- és képességfejlődés nagy intervallumát fedi le, ezért az életkori csoportok féléves bontás mellett döntöttünk. A minta féléves bontását, illetve a gyermek mintaelemszámát és teszten elért teljesítményét a 39. táblázat tartalmazza. A féléves életkori csoportok között az összteljesítmény tekintetében szignifikáns különbség tapasztalható $(F(7,4334)=7,35, p<0,01)$, a 2008. 2. félévben született tanulók szignifikánsan gyengébb teljesítményt nyújtottak a náluk fiatalabb korosztálynál. 
39. táblázat. A tanulók teljesitményének átlaga és szórása a születési félév függvényében

\begin{tabular}{llccc}
\hline \multirow{2}{*}{ Születési félév } & $\begin{array}{c}\text { Átlag } \\
(\%)\end{array}$ & $\begin{array}{c}\text { Szórás } \\
(\%)\end{array}$ & $\mathrm{N}$ \\
\hline \multirow{2}{*}{2007} & 1. félév & 52,70 & 26,19 & 54 \\
& 2. félév & 51,00 & 21,97 & 23 \\
\multirow{2}{*}{2008} & 1. félév & 46,16 & 21,42 & 51 \\
& 2. félév & 46,70 & 21,25 & 274 \\
\multirow{2}{*}{2009} & 1. félév & 53,62 & 22,54 & 790 \\
& 2. félév & 56,03 & 22,40 & 2075 \\
\multirow{2}{*}{2010} & 1. félév & 54,24 & 23,30 & 873 \\
& 2. félév & 55,14 & 21,49 & 202 \\
\hline
\end{tabular}

A fonématörlés részteszt $(F(7,4309)=2,01 p>0,05)$ kivételével az ANOVA elemzés minden esetben szignifikáns különbség jelentkezett. A fonémaszintézis $(F(7,4312)=2,61 p<0,05)$ esetében a post hoc teszt nem mutatott rá a szignifikáns korcsoportbeli különbségekre. Az azonosítás múvelete $(F(7,4334)=8,71 \mathrm{p}<0,01)$ szerint a 2008. 1. és 2. félévében születettek teljesítménye szignifikánsan gyengébb a náluk fiatalabb tanulók ezen műveleti szinten nyújtott teljesítményétől. A fonémaszegmentálás esetében $(\mathrm{F}(7,4322)=4,00 \mathrm{p}<0,01)$ a 2008.2 . félévében született tanulók szignifikánsan gyengébb teljesítményt nyújtottak fiatalabb társaiknál. A fonémaazonosítás részteszt $(F(7,4334)=5,55 \quad p<0,01)$ esetében a 2009. 2. félévében született tanulók szignifikánsan jobban teljesítettek, mint a 2008. 1. félévében születettek. A fonémaazonosítás a hívóhang helyének meghatározásával feladattípus ( $\mathrm{F}(7$, 4329)=5,08 p <0,01) esetében a 2008. 2. félévében születettek szignifikánsabb gyengébb teljesítményt nyújtottak, mint a náluk fiatalabb korosztály, a szókezdő hang azonosítását kérő részteszt $(F(7,4315)=8,71 p<0,01)$ esetében pedig a 2008. 1. félévében születettek a 2009. 2. és 2010. 1. félévében születetteknél, a 2008. 2. félévében születettek pedig a náluk fiatalabb korosztálynál nyújtottak szignifikánsan gyengébb teljesítményt.

\section{2. 6. A fonématudatosság teszt és a számítógép-használat teszt összefüggése az} első osztályosok esetében

Az első osztályosok fonématudatosságának vizsgálata során csak kattintást igénylő feladatok szerepeltek a tesztben, hiszen a szegmentálás feladat cseréjével az egyetlen vonszolást kérő feladatot is lecseréltük (6.1.2. fejezet). Jelen esetben tehát a teljes géphasználat és a teljes 
fonématudatosság teszt között, valamint a kattintást igénylő géphasználat feladatok és a teljes fonématudatosság teszt közötti magyarázóerő vizsgálatára szorítkoztunk (40. táblázat).

A tanulók a géphasználat teszten nyújtott teljesítménye átlagosan 86,96\%pont (szórás $=15,45 \%$ pont), a géphasználat kattintást igénylő feladatain pedig átlagosan $86,10 \%$ pont (szórás $=13,67 \%$ pont). A fonématudatosság teszt és a kattintós géphasználat feladatok közötti megmagyarázott variancia 4,4\% $(\mathrm{F}(1,4179)=191,45, \mathrm{p}<0,01)$. Teljes géphasználat 7,3\%-ban magyarázza a teszten nyújtott teljesítményt $(\mathrm{F}(1,4179)=327,56, \mathrm{p}<0,01)$. Mindkét esetben szignifikáns magyarázóerő jelentkezik.

40. táblázat. A géphasználat teszt és a fonématudatosság teszt összefüggésének vizsgálata az elsö osztályos tanulók körében

\begin{tabular}{cccccc}
\hline & $\mathrm{r}$ & $\beta$ & $\mathrm{r} \beta * 100$ & $\mathrm{p}$ & $\mathrm{r}^{2}$ \\
\hline Teljes teszt & 0,27 & 0,27 & 7,29 & $<0,01$ & 0,07 \\
Kattintás & 0,21 & 0,21 & 4,41 & $<0,01$ & 0,04 \\
\hline
\end{tabular}

\section{3. Az első osztályos tanulók körében rögzített fonématudatossági teszt eredményeinek összefoglalása}

A 2016-ban rögzített fonématudatosság teszt a 2015-ös munka javított, fejlesztett változata. Az új konstruktumban eltávolításra kerültek a szótagtudatosságot vizsgáló feladatok. Egyrészt azért, mert a fonológiai tudatosságot, beszédhanghallás vizsgáló iskolakészültségi tesztek már fonémaszintü mủveletek alkalmaznak, valamint - a gyermekek képességeit figyelembe véve - a szótagszintü műveletek és manipuláció már nem okozhat gondolt az általános iskola első osztályát megkezdett, azaz iskolaérett tanuló számára. Jordanidisz (2017) kimutatta, hogy a szótagtudatosság fejlődése folyamatos, illetve már a 4 éves magyar gyermekek többségének nem okoz gondot a valódi szavak szótagszám szerinti bontása. Kutatása arra is rámutatott, hogy a fonématudatosság fejlődése az olvasás- és írástanulás, tanítás hatására jelentős (Jordanidisz, 2017). Másrészt a 2015-ös tesztfelvételhez képest csökkenteni kívántuk a vizsgált nyelvi képességek, valamint a géphasználat teszt között fellépő megmagyarázott variancia mértékét, ezért a tanulók számára egyszerűbben megválaszolható feladatmegjelenítési formát fejlesztettünk, kiiktatva ezzel a vonszolás műveletére épülő feladatokat.

A 2016-os mintavétel során 4342 tanuló töltötte ki a tesztet, melyet az Oktatáselméleti Kutatócsoport partnerhálózata biztosított. A minta sem a régiók sem a megyék szintjén nem 
tekinthető reprezentatívnak sem a teljes minta, sem a nemek szerinti bontás tekintetében. A 2015-ös tesztböl eltávolítva a szótagszintü feladatokat, 40 fonémaszintủ feladattal történt az adatfelvétel. Az elsődleges elemzések, a teszt megbízhatóságának és a teszt-item korrelációk vizsgálata után a további elemzésekbe 37 itemet vontunk be. Az eltávolított három item mind, a dichotóm, fonémaazonosítást kérő feladatok közül került ki.

A teszt személy-item térképe alapján leolvasható, hogy bár a feladat megjelenítési formájában, illetve a válaszadás módjában változás történt, a szegmentálás feladatok továbbra is nehéznek bizonyultak az első osztályosok számára, viszont a müveletek szerinti elkülönülés jelen elemzésben nem külön el élesen, hiszen a szegmentálás és azonosítás feladatok, valamint a szintézis és törlés feladatok az itemnehézségük tekintetében vegyülnek. A teszt belső szerkezetének vizsgálatakor a szintézis és a törlés feladatok között tapasztaltuk a legerősebb összefüggést ( $\mathrm{r}=0,59, \mathrm{p}<0,01)$.

A tanulók teszten nyújtott teljesítménye 53,87\%pont, mely megfelel az elvárásainknak. A szókezdő hang azonosítását kérő feladat differenciálta leginkább a tanulókat, a legalacsonyabb átlagteljesítményt pedig szegmentálás feladat esetében tapasztalhatjuk. A teszten nyújtott teljesítmény mind a müveletek, mind az összteszt szintjén a lányok előnyét mutatja.

A tanulók életkori bontása alapján az 2016-os első évfolyamos tanulók négy születési évet fednek le (2007-2010). Legnagyobb mértékben a 2009-ben, tehát a vizsgálat évében 7. életévüket betöltött vagy betöltő tanulók jelennek meg. Az összteszt tekintetében a 2009-es és 2010-es tanulók, (tehát azok, akik egy évvel később, vagy valóban a koruk szerinti iskolaérettség tekintetében kezdték meg az első osztályt) szignifikánsan jobb teljesítményt nyújtottak, mint a 2008-as születésüek, azaz átlagosan 7,59 éves tanulók. Feltételezhető, hogy a 2008-ban vagy 2007-ben született tanulók esetében egyéb, nem feltétlenül kognitív tényező miatti óvodai évismétlésre került sor, hiszen a féléves bontás során is szembetűnő, hogy a 2007. 1. félévében született tanulókat differenciálta leginkább a fonématudatosság teszt, valamint az is, hogy a két idősebb korosztály átlagteljesítménye, bár közel azonos szórásértékkel, de kis mértékben elmarad a két fiatalabb korosztályétól. Ugyanez a tendencia a feladattípusok esetében is megjelenik. Ezen feltételezések bizonyítása további háttéradatok bevonását igényelné, illetve a további fejlesztések megvalósításához pedagógusok figyelmét a korábbi mérési, iskolakészültségi, szakszolgálati adatok be- és elkérésére ösztönözetné.

A szegmentálás feladat megjelenítési formájának megváltoztatásával bár a feladat nehézségi szintje nem, viszont a géphasználat és a fonématudatosság teszt közti megmagyarázott variancia csökkent. 
Összességében megállapítható, hogy a fonématudatosság teszt megbízható mérőeszköze az általános iskola első osztályos tanulói számára. A tesztfejlesztés további állomásaként viszont nem elhanyagolható az újabb részterületek, feladattípusok vizsgálatba történő bevonása, az egyes feladattípusok itemszámának bővítése, a hangok környezete, szóban betöltött pozíciója és a hang minősége szerinti csoportosítása, valamint a pontosabb monitorozást segítő adaptív teszt fejlesztése (Csapó, Molnár, \& R. Tóth, 2008). 


\section{A FONOLÓGIAI TUDATOSSÁG TESZT ADAPTÁLHATÓ RÉSZEINEK ONLINE TESZTELÉSE AZ ÓVODAI KOROSZTÁLY KÖRÉBEN}

\section{1. Módszerek}

\section{1. 1. Minta}

Az óvodai mintában szereplő gyermekek Szeged Megyei Jogú Város Önkormányzati Óvodáiból kerültek ki, egyéni mintaszervezés által, kizárólag önkéntes csatlakozás alapján. A mintában szereplő összes gyermek szülöje vagy törvényes képviselője beleegyező nyilatkozatot írt alá, mellyel támogatta a kutatási munkánkat (8. melléklet). A mintaszervezés során elsődleges cél volt, hogy olyan gyermekek kerüljenek a mintába, akik a vizsgálat évében korukból adódóan tankötelessé válnak, tehát a vizsgálat évének szeptember 1-jéig betöltik a hatodik életévüket. Az óvodai csoportstruktúrából adódóan (heterogén csoportok) a tesztet olyan gyermek is kitöltötték, akik nem feleltek meg az előbb említett kritériumnak. Szinte minden csoportban szerepelt néhány olyan gyermek, aki adott év szeptemberéig nem vált kora szerint tankötelessé, viszont őket a játékból/tesztelésből kihagyni, a gyerekek online tesztek iránti motivációját látva, nem tartottuk fontosnak. A fiatalabb korosztály adatai jelen elemzésekben nem jelennek meg. A kutatásban, összesen 18 óvoda 472 gyermeke vett részt, melyből a kívánt kritériumoknak 317 vizsgált gyermek felelt meg. Közülük 311 óvodás gyermek válaszolta meg végig a tesztkérdéseket. A vizsgálatban szereplő gyermekek átlagéletkora 6,61 év (szórás=0,54 év).

\section{1. 2. Mérőeszköz}

A mérőeszköz a 2015-ös, első osztályos mintán is alkalmazott részterületeket és feladattípusokat tartalmazta, a feladatok példaanyagai is teljes egyezöséget mutatnak. Mivel a teljes tesztet, illetve a feladatok megjelenítési formáját az 5.1. 2. fejezet részletesen bemutatja, ezért jelen esetben eltekintünk ettől.

\section{1. 3. Eljárás}

\section{1. 3. 1. A közvetitö médium szerepe az óvodai tesztelések során}

2014 öszén az eDia rendszer fejlesztései lehetővé tették, hogy az eddig asztali számítógépen alkalmazott tesztek érintőképernyős eszközökre is átültethetővé váljanak. Igazodva az óvodás 
korosztályú gyermekek körében használt eszközök kialakításához, célszerünek láttuk az érintőképernyős tesztelési forma kialakítását, minél nagyobb képernyőjü eszköz alkalmazásával, így az óvodai tesztelések esetében a 10'1'”-os tabletek használata mellett döntöttünk. A gyermekek tabletek segítségével, fejhallgatókon keresztül kapták meg a feladat megoldásához szükséges instrukciót, a feladatokat saját ütemükben oldhatták meg. A fejhallgatókon keresztül kapott utasítás, valamint a gyermekek eszközökön történő önálló válaszadása lehetővé tette az eddigi szemtől-szembeni tesztelések során elképzelhetetlen, kiscsoportos tesztelést. Így az óvodai mérések egyszerre öt gyermek együttes tesztelését tették lehetővé. A gyermekek számának meghatározása egyrészt a technikai feltételek miatt vált szükségessé, másrészt pedig, megfigyeléseink alapján, öt gyermek még ösztönzi egymást a gördülékeny munkavégzésre, a gyermekek közti kooperáció bár megjelenik, de a kommunikáció maga többnyire nem verbális és nem a feladatok tartalmára irányul. A technika feltétel meghatározása egyszerü, hiszen az óvodák infrastruktúrája nem teszi lehetővé az óvodai wifi-hálózaton át történő tesztelést, míg az alkalmazott mobilinternetek sávszélessége az öt eszközön történő tesztelést biztosítani képes.

\section{1. 3. 2. A méröbiztosok szerepe az óvodai online tesztelések során}

Az óvodai mérések megvalósítása fokozottan igényelte a megfelelő mérőbiztosok jelenlétét. $\mathrm{Az}$ online tesztek felvételét a Szegedi Tudományegyetem Juhász Gyula Pedagógusképző Karának óvodapedagógus, tanító és szociálpedagógia szakos hallgatói, valamint a Szegedi Tudományegyetem Neveléstudományi Intézetének alap- és mesterképzésben résztvevő hallgatói végezték. A hallgatók előzetesen egyetemi kurzuson vettek részt, melyben a munka elméleti hátterére kaptak rálátást, illetve megtekintették a teszteket, eligazítást kaptak a végzendő munka gyakorlati részéhez. Felhívtuk a figyelmüket egyes, óvodában jelentkező szituációra (pl. egészségügyi szünetek), melyekre szituációs gyakorlatok segítségével megoldásokat is kerestünk.

A hallgatók kettesével teljesítették a gyakorlatot, és mivel több hallgató visszatérő kurzuslátogató volt már a 2016-os adatfelvétel idejére, ezért a mérőbiztosi párok egy, már korábban gyakorlatot szerzett hallgatóból és egy, pozíciót frissen betöltő csoporttársából állt. Az óvodai mérések a méröbiztosi szerepkör kettősségét kívánják meg, hiszen a gyermekek csoportszobából való kiemelésétől, megnyugtatásától, rövid, játékra való hangolásától, egészen a játék végi élménybeszámolójukig fokozottabb figyelmet igényelnek, mint az általános iskolai tesztelésben résztvevő tanulók. Éppen ezért a mérőbiztosi feladatok felosztása során arra tettünk javaslatot, hogy az egyik mérőbiztos magának a tesztfelvételnek a sikeres lebonyolítására 
koncentráljon, rögzítse az anonim mérési azonosítókat, figyelje és segítse a tesztben történő dimanikus haladást, addig a másik mérőbiztos a gyermekek esetleges felmerülő igényeire, szükségleteire, motivációjának fenntartására fókuszáljon.

\section{1. 3. 3. A rögzitendö teszt helye a mérési folyamatban}

A fonológiai tudatosságot vizsgáló mérőeszköz egy, négy tesztet tartalmazó tesztbattéria elemeként került felvételre. A battéria további elemei között szerepelt a géphasználat/eszközhasználatot vizsgáló játékos feladatsor, a gyermekek induktív gondolkodását vizsgáló és a matematikatanulás előfeltételeit vizsgáló feladatsor. A mérési folyamat kezdeteként minden gyermek elöször a géphasználat tesztet töltötte ki, ezzel biztosítottuk, hogy ismerősek legyenek a tableteken elvégezhető müveletek. Másodikként az induktív gondolkodás, majd a fonológiai tudatosság és a matematikatanulás előfeltételeit vizsgáló feladatok kerültek rögzítésre, minden esetben külön ülésben, tehát egy gyermek egy mérési alkalommal csupán egy tesztet töltött ki. Mivel a tesztek rögzítése külön napon történt, ezért az egyes kognitív területeket vizsgáló tesztek előtt is szerepelt egy-egy, a géphasználatra vonatkozó gyakorlófeladat, mintegy ráhangolódásként az aznapi feladatsorra. A gyakorló feladatok csak olyan müveletekre fókuszáltak, melyek aznap szerepeltek. A fonológiai tudatosság tesztben az egy és két mezőre/képre történő kattintás, valamint a drag \& drop funkció használata, azaz a vonszolás jelent meg. Az adott mủveletekre vonatkozó feladatok a dolgozat 3. mellékletében szerepelnek, jelen fejezet olyan példafeladatokat tartalmaz (42. és 43. ábra), melyek csak az óvodás korosztály géphasználati feladatai között jelentek meg, illetve az 43. ábra feladata már a válasz (pötty) eltávolítási lehetőségére is kitér (Pásztor, 2016). 


\section{$-(\lambda)$}

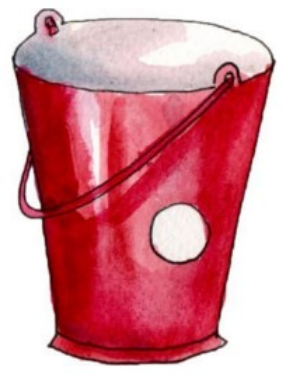

42. ábra

Célmezőbe való kattintás gyakorlása Instrukció: Kilyukadt a vödör. Foltozd be minél gyorsabban! A befoltozáshoz kattints a lyukra! Ha készen vagy, kattints a nyílra!

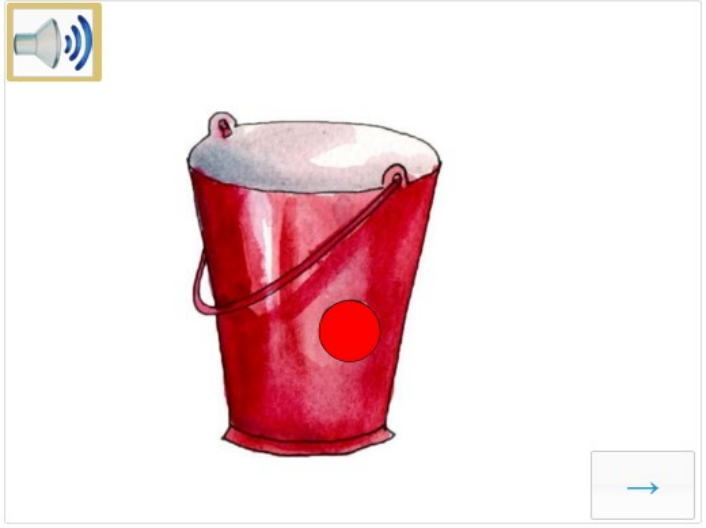

43. ábra

Adott célmezöbe történő válasz törlése/javitása Instrukció: A piros pöttyöket törölni is tudod. A törléshez rájuk kell kattintani. Most lyukasszuk ki a vödröt! Kattints rá a piros pöttyre a törléshez! Ha készen vagy, kattints a nyillra!

A vonszolást kérő mintafeladatok kialakítása során előtérbe került a feladatok irányultságának kérdése, így a példafeladatok kialakítása a függőleges (44. ábra), illetve a balról jobbra történő mozgatásokat (45. ábra) helyeztük előtérbe.

\section{(1))}

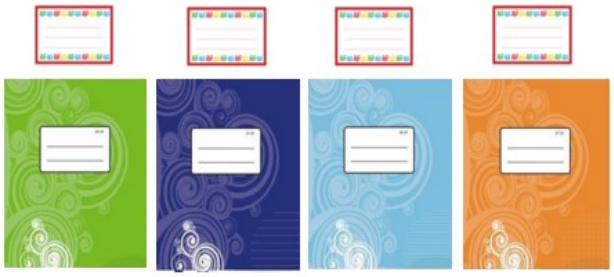

10. ábra

Példafeladat a függöleges vonszolás gyakorlására

Instrukció: Már csak a névmatricák hiányoznak a füzeteidröl. Húzd az egyes matricákat az alattuk található füzetekre!

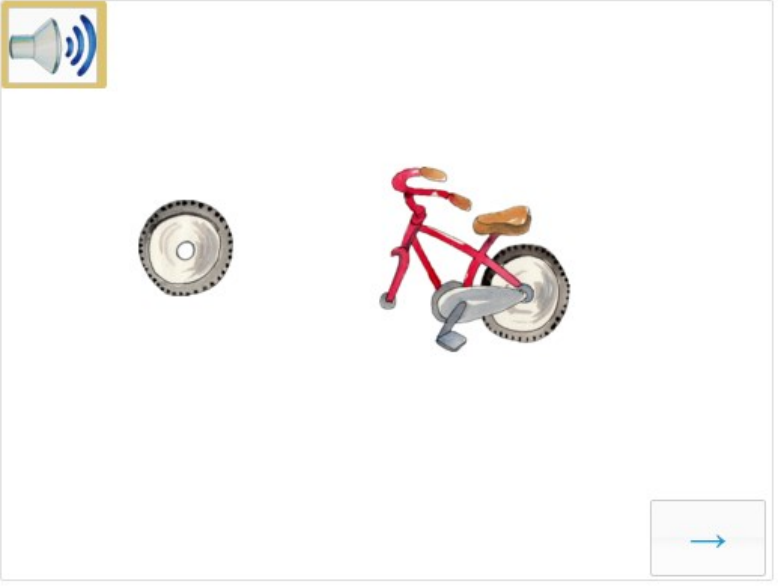

45. ábra

Példafeladat a balról jobbra történő vonszolásra Instrukció: Szereld meg a biciklid! Húzd a pótkereket a hiányzó kerék helyére olyan gyorsan, ahogyan csak tudod! 


\section{2. Eredmények}

\section{2. 1. A mérőeszköz megbízhatóságának vizsgálata}

A fonológiai tudatosság teszt megbízhatósági mutatóit és a mintaelemszámokat a 41 . táblázat foglalja össze. A táblázatban továbbá megjelennek a feladattípusok, müveletek és részterületek szerinti bontások adatai is. Bár a teszt 311 kitöltő eredménye alapján, összteszt szinten, megbízhatóan mér (Cronbach- $\alpha=0,82$ ), a résztesztek megbízhatósága nem éri el a kívánt, 0,80-as Cronbach- $\alpha$ értéket, sőt egyedül a szótagszegmentálás részteszt közelíti meg azt. A fonémaazonosítás feladattípus Cronbach- $\alpha$ értéke a legalacsonyabb (Cronbach- $\alpha=0,41)$. Ez az egyetlen feladattípust, mely a válaszadás szempontjából dichotóm, a gyermekek két lehetőség között kattintással döntenek. A résztesztek reliabilitása után a nyelvi egység mérete szerinti tagolódást, valamint a müveletek szintjén történő tagolódás megbízhatóságát is vizsgáltuk. Ennek tükrében a szótagszintü feladatok megbízhatósági mutatója alacsony, míg a fonéma szintű feladatok elérik a képességmérő tesztek esetében kívánatos 0,80 -as Cronbach- $\alpha$ értéket. A müveletek szerinti tagolódás szerint az azonosítást kérő feladattípusok összesített mutatója közelíti meg az elvárt értéket.

41. táblázat. A fonológiai tudatosság teljes tesztjének és résztesztjeinek reliabilitás mutatói (Cronbach- $\alpha$ )

\begin{tabular}{cccc}
\hline A teszt megnevezése & Itemek száma & Cronbach- $\alpha$ & $\mathrm{N}$ \\
\hline Szótagszintézis & 5 & 0,41 & 317 \\
Szótagszegmentálás & 5 & 0,79 & 317 \\
Szótagtörlés & 5 & 0,41 & 316 \\
Fonémaazonosítás & 10 & 0,39 & 315 \\
Fonémaazonosítás a & & & \\
hívóhang helyének & 10 & 0,56 & 312 \\
meghatározásával & & & \\
Szókezdő hang & 5 & 0,64 & 312 \\
azonosítása & 5 & 0,68 & 311 \\
Fonémaszintézis & 5 & 0,51 & 312 \\
Fonémaszegmentálás & 5 & 0,65 & 311 \\
Fonématörlés & 25 & 0,72 & 312 \\
\hline Azonosítás & 10 & 0,65 & 311 \\
Szintézis & 10 & 0,62 & 312 \\
Szegmentálás & 10 & 0,64 & 311 \\
Törlés & 15 & 0,65 & 311 \\
\hline Szótag szintü feladatok & 40 & 0,81 & $\mathbf{3 1 1}$ \\
Fonéma szintü & $\mathbf{5 5}$ & $\mathbf{0 , 8 2}$ & \\
feladatok & & & \\
\hline Teljes teszt & & & \\
\hline
\end{tabular}


Az elkülönítés mutatók alapján csupán két item értéke sorolható 0,1 alá (9. melléklet). Az itemek elkülönítés mutatóinak eloszlását az 46. ábra mutatja be. Az 55 tesztfeladatból 25 tesztitem korrelációja éri el vagy haladja meg a 0,35-ös korrelációs értéket. Tekintve ezen értékeket, valamint az itemek elhagyása esetén történő részteszt és teszt szintű reliabilitás növekedését a 0,3-as korrelációs értéket el nem érő itemek eltávolítása mellett döntöttünk, így a módosított teszt 44 itemet tartalmaz (42. táblázat). Az alacsony teszt-item korrelációval rendelkező itemek eltávolítása után a teljes teszt megbízhatósága nőtt, ugyanez tapasztalható a szótag és fonémaszintü feladatok, az azonosítás és törlés müvelete, valamint a szótagszegmentálás és fonémaazonosítás feladattípusok esetében. Az 42. táblázat utolsó oszlopából leolvasható, hogy csupán 6 gyermek nem fejezte be a tesztet, közülük kettő csupán a szótagszintű feladatokra adott választ. A tesztfeladatokban töltött átlagos idő 21,43 perc (szórás=8,81 perc), mely megfelel az előzetes elvárásoknak, az óvodás korosztály számára könnyen teljesíthető.

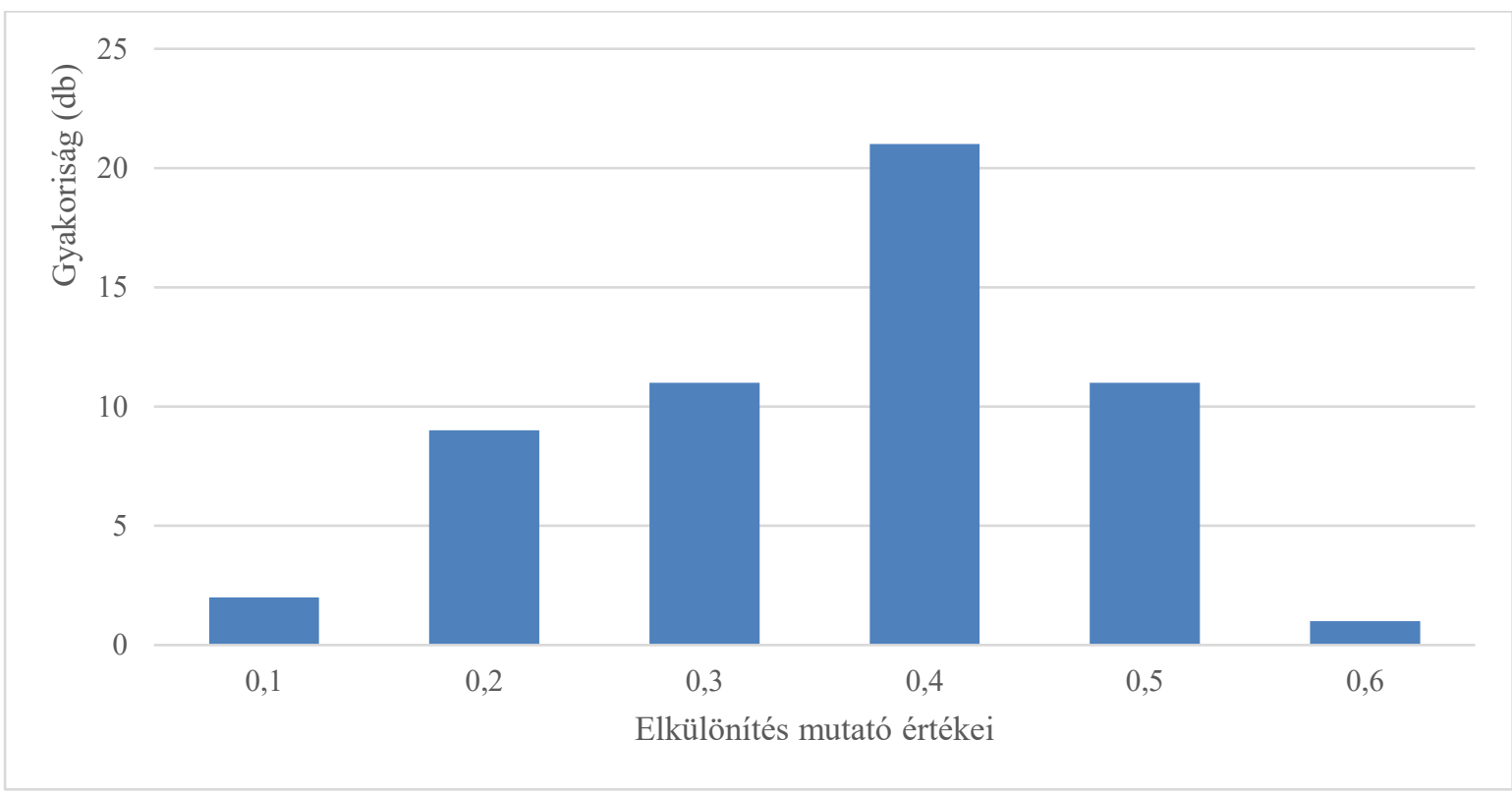

46. ábra

Az itemek elkülönités mutatóinak eloszlási gyakorisága 
42. táblázat. Az elkülönités mutatók figyelembe vételével módositott teszt felépitése, a teljes teszt és a résztesztek reliabilitás mutatói (Cronbach- $\alpha$ )

\begin{tabular}{cccc}
\hline A teszt megnevezése & Itemek száma & Cronbach- $\alpha$ & $\mathrm{N}$ \\
\hline Szótagszintézis & 3 & 0,27 & 317 \\
Szótagszegmentálás & 4 & 0,80 & 317 \\
Szótagtörlés & 3 & 0,38 & 316 \\
Fonémaazonosítás & 6 & 0,69 & 315 \\
Fonémaazonosítás a & & & \\
hívóhang helyének & 10 & 0,56 & 312 \\
meghatározásával & & & \\
Szókezdő hang & 5 & 0,64 & 312 \\
azonosítása & 5 & 0,68 & 311 \\
Fonémaszintézis & 3 & 0,48 & 312 \\
Fonémaszegmentálás & 5 & 0,65 & 311 \\
Fonématörlés & 21 & 0,76 & 312 \\
\hline Azonosítás & 8 & 0,64 & 311 \\
Szintézis & 7 & 0,62 & 311 \\
Szegmentálás & 8 & 0,68 & 311 \\
Törlés & 10 & 0,66 & 311 \\
\hline Szótag szintű & & & $\mathbf{3 1 1}$ \\
feladatok & 34 & 0,83 & \\
Fonéma szintü & $\mathbf{4 4}$ & & \\
feladatok & & $\mathbf{0 , 8 4}$ & \\
\hline Teljes teszt & $\mathbf{4 4}$ & & \\
\hline
\end{tabular}

\section{2. 2. A feladatok nehézségének és a gyermekek képességszintjének feltárása}

A feladatok nehézségének és a gyermekek képességszintjének feltárására a Rasch modellt alkalmaztuk (47. ábra). Az elemzés során kapott EAP/PV reliabilitás mutató értéke 0,84, mely megfelelőnek tekinthető. Az ábra bal oldalán lévő skála a feladatok nehézségét, míg jobb oldala a tanulók képességszintjét jelzi. Az ábra bal oldalán lévő minden x 2.0 tanulót reprezentál. A könnyebb áttekinthetőség érdekében a fonémaszintű feladatokat a színpaletta hideg, míg a szótagszintű feladatokat a paletta meleg árnyalatai jelzik. Így fonémaazonosítást kék, a fonémaszegmentálást türkiz, a fonématörlést sötétzöld, a fonémaszintézist szürke, míg a szótagszegmentálást arany, szótagszintézist narancssárga és a szótagtörlést halvanysárga színek jelölik. Az ábra jobb oldalán lévő számok a teszt itemeit jelölik. Az itemek a képességskála széles tartományát lefedik, -3,324 és 2,310 közötti logitértékkel rendelkeznek. A két szélső értéket képviselő item elkülönül a többitől. A szegmentálást kérő itemek a 0,926 és 2,310 közötti logitértékkel rendelkeznek, az azonosítás feladatok az 1,186 és az 0,191-es logitértékek között találhatók, ezen érték alatt helyezkednek a szintézist és a törlést kérö itemek. Egyetlen azonosítást kérő item jelentősen, -1,010-es logitértékkel elkülönül a többitől azonos műveletet 
kérö itemtípustól. A feladatok nehézségi szintje tehát a nyelvi egység mérettől függetlenül, a müveletek szerint különül el. 


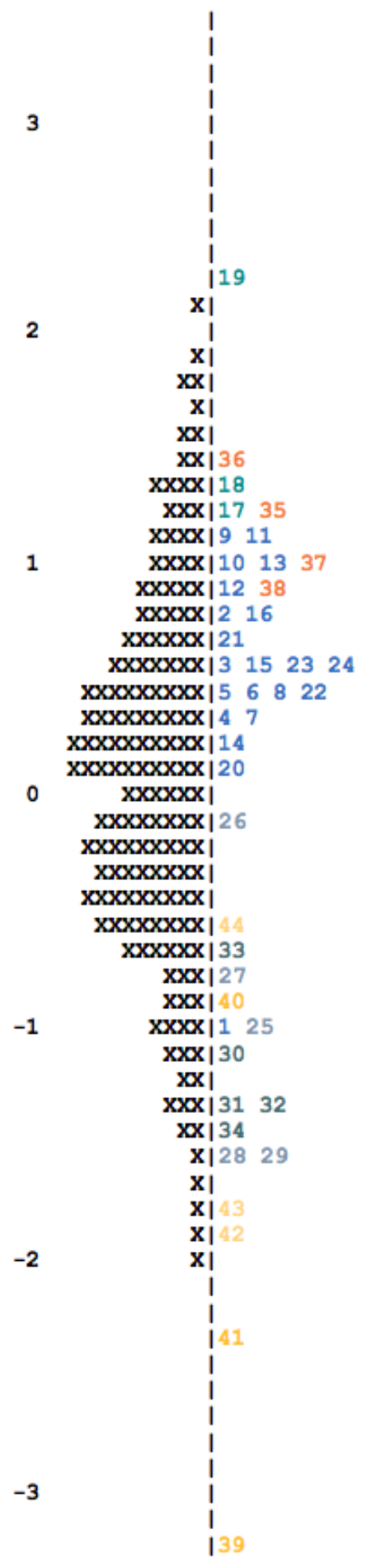

\section{7. ábra}

Az óvodai korosztály esetében rögzitet fonológiai tudatosság teszt személy-item térképe. A fonémaszintü feladatokat a színpaletta hideg, míg a szótagszintü feladatokat a paletta meleg árnyalatai jelzik. Így fonémaazonositást kék, a fonémaszegmentálást türkiz, a fonématörlést sötétzöld, a fonémaszintézist szürke, míg a szótagszegmentálást arany, szótagszintézist narancssárga és a szótagtörlést halvanysárga színek jelölik. 


\section{2. 3. A fonológiai tudatosság teszt belső konstruktumának vizsgálata}

A teszt belső konstruktumának vizsgálatára a résztesztek közti korrelációk feltárását, valamint a CFA (Confirmatory Factor Analyses) módszerét alkalmaztuk. Korrelációk vizsgálata során figyelme vettük a nyelvi egység mérete szerinti tagolódást, a müveletek szerinti tagolódást és a vizsgált területek szerinti tagolódást is. A nyelvi egység mérete szerinti tagolódás esetében a szótag szubteszt 10, míg a fonéma 34 itemből állt. A korrelációs együttható a résztesztek és az összteszt között erős összefüggést mutatott, míg a két nyelvi egység között gyenge korrelációt tapasztaltunk (43. táblázat).

\section{3. táblázat. A nyelvi egységek és a teljes teszt közti korrelációs együtthatók}

\begin{tabular}{ccc}
\hline & Szótag & Fonéma \\
\hline Fonéma & 0,39 & \\
Teljes teszt & 0,61 & 0,97 \\
\hline
\end{tabular}

Megjegyzés: minden korreláció szignifikáns $p<0,01$ szinten

A müveletek szerinti elkülönítés szerint, a nyelvi egység méretétől függetlenül, az azonosítás 21 , a szintézis 8 , a szegmentálás 7 , a törlés pedig 8 itemes egységekben jelenik meg. A müvelet szerinti tagolódás tekintetében a területek között gyenge vagy közepes összefüggést tapasztaltunk, míg a teljes teszttel a szegmentálás művelete közepes, a többi a műveleti szint erős korrelációs értéket mutatott. (44. táblázat)

44. táblázat. A müveleti szintek és a teljes teszt közti korrelációs együtthatók

\begin{tabular}{ccccc}
\hline & Szegmentálás & Szintézis & Törlés & Azonosítás \\
\hline Szintézis & 0,29 & & & \\
Törlés & 0,28 & 0,56 & & \\
Azonosítás & 0,35 & 0,47 & 0,43 & 0,88 \\
\hline Teljes teszt & 0,57 & 0,73 & 0,71 &
\end{tabular}

Megjegyzés: minden korreláció szignifikáns p<0,01 szinten

A feladattípusok szerinti elkülönülés esetében (45. táblázat) a teljes teszt és a feladattípusok közti korrelációs érték gyenge vagy közepes összefüggést mutat, míg a feladattípusok közti korrelációs értékek többségükben gyengék. A teljes teszttel a szótagszintézis feladattípus mutatta a leggyengébb, a fonémaazonosítás a hang helyének meghatározásával feladattípus pedig a legerősebb összefüggést. Érdemes viszont azt is 
megemlíteni ezen értékek mellett, hogy a szótagszintézis feladatok a teljes teszt 6\%-át, míg a fonémaazonosítás a hang helyének meghatározásával feladatok a teszt 23\%-át foglalják magukban. A feladattípusok közti korrelációs értékek között elhanyagolható a szegmentálás résztesztek közti összefüggés, míg ezen értékek között a legmagasabbnak, bár így is csak közepes erősségünek tekinthető a fonématörlés és fonémaszintézis kapcsolata. Az eltérő itemszámok miatt a korrelációs mátrix csupán támpontként szolgál a későbbi CFA modellek kialakításához.

45. táblázat. A résztesztek és a teljes teszt közti korrelációs együtthatók

\begin{tabular}{|c|c|c|c|c|c|c|c|c|c|}
\hline & Sz_Szeg & Sz_Szin & Sz_Tor & F_Az & F_Hh & F_Szeg & F_Szh & F_Szin & F_Tor \\
\hline Sz_Szin & 0,16 & & & & & & & & \\
\hline Sz_Tor & 0,24 & 0,18 & & & & & & & \\
\hline F_Az & $0,12^{*}$ & $0,12^{*}$ & $0,12^{*}$ & & & & & & \\
\hline $\mathrm{F} \_\mathrm{Hh}$ & 0,25 & 0,21 & 0,23 & 0,39 & & & & & \\
\hline F_Szzeg & $0,14^{*}$ & 0,02 & 0,15 & 0,18 & 0,27 & & & & \\
\hline F_Szh & 0,22 & 0,10 & 0,22 & 0,21 & 0,45 & 0,31 & & & \\
\hline F_Szin & 0,25 & $0,14^{*}$ & 0,34 & 0,19 & 0,36 & 0,25 & 0,37 & & \\
\hline F_Tor & 0,16 & $0,14^{*}$ & 0,42 & 0,18 & 0,37 & 0,21 & 0,30 & 0,51 & \\
\hline Teljes teszt & 0,40 & 0,40 & 0,48 & 0,57 & 0,77 & 0,44 & 0,65 & 0,66 & 0,64 \\
\hline
\end{tabular}

A teszt belső struktúrájának további vizsgálatára a megerősítő faktoranalízis módszerét alkalmaztuk. A felállított modellek megegyeznek az első osztályosok teljes teszttel végzett vizsgálatai során felállított modellekkel. Az óvodás gyermekek esetében is a 9-dimenziós modell rendelkezett megfelelő illeszkedésmutatókkal (46. táblázat). Mivel a felállított modell a dimenziók kapcsolatára nem adott pontos választ, ezért ebben az esetben is a modellek kirajzolása, az egyes kapcsolatok meghatározása mellett döntöttünk (47. táblázat és 48-50. ábra). A felrajzolt modellek közül a harmadik modellünk bizonyult fitnek, ez alapján kijelenthető, hogy a teszt belső konstruktumát nem a nyelvi egység mérete, hanem a nyelvi egységekkel végrehajtott műveletek határozzák meg (50. ábra). 
46. táblázat. Az óvodai fonológiai tudatosság teszt megerősitö faktorelemzésének eredményei

\begin{tabular}{ccccccc}
\hline Modell & $\chi^{2}$ & $d f$ & $p$ & CFI & TLI & RMSEA (95\% CI) \\
\hline 1-dimenziós & 1912,218 & 902 & 0,000 & 0,516 & 0,492 & $0,060(0,056-0,064)$ \\
2-dimenziós & 1655,193 & 901 & 0,000 & 0,639 & 0,621 & $0,052(0,048-0,056)$ \\
4-dimenziós & 1393,087 & 896 & 0,000 & 0,762 & 0,748 & $0,042(0,038-0,046)$ \\
7-dimenziós & 1287,484 & 881 & 0,000 & 0,805 & 0,791 & $0,039(0,034-0,043)$ \\
9-dimenziós & 1045,874 & 866 & 0,000 & 0,916 & 0,906 & $0,026(0,020-0,031)$ \\
\hline
\end{tabular}

Megjegyzés: $d f=$ degrees of freedom; $C F I=$ Comparative Fit Index; $T L I=$ Tucker-Lewis Index; RMSEA = Root Mean Square Error of Approximation; $\chi^{2}$ and df are estimated by WLSM5.

47. táblázat. Az óvodai fonológiai tudatosság teszt belsö kontsruktumának meghatározása

\begin{tabular}{ccccccc}
\hline Modell & $\chi^{2}$ & $d f$ & $p$ & CFI & TLI & RMSEA (95\% CI) \\
\hline Modell 1 & 1124,769 & 893 & 0,000 & 0,889 & 0,882 & $0,029(0,023-0,034)$ \\
Modell 2 & 1124,750 & 891 & 0,000 & 0,888 & 0,881 & $0,029(0,023-0,034)$ \\
Modell 3 & 1088,160 & 889 & 0,000 & 0,905 & 0,901 & $0,027(0,021-0,032)$ \\
\hline
\end{tabular}

Megjegyzés: $d f=$ degrees of freedom; $C F I=$ Comparative Fit Index; TLI = Tucker-Lewis Index; RMSEA = Root Mean Square Error of Approximation; $\chi 2$ and df are estimated by WLSM5. 


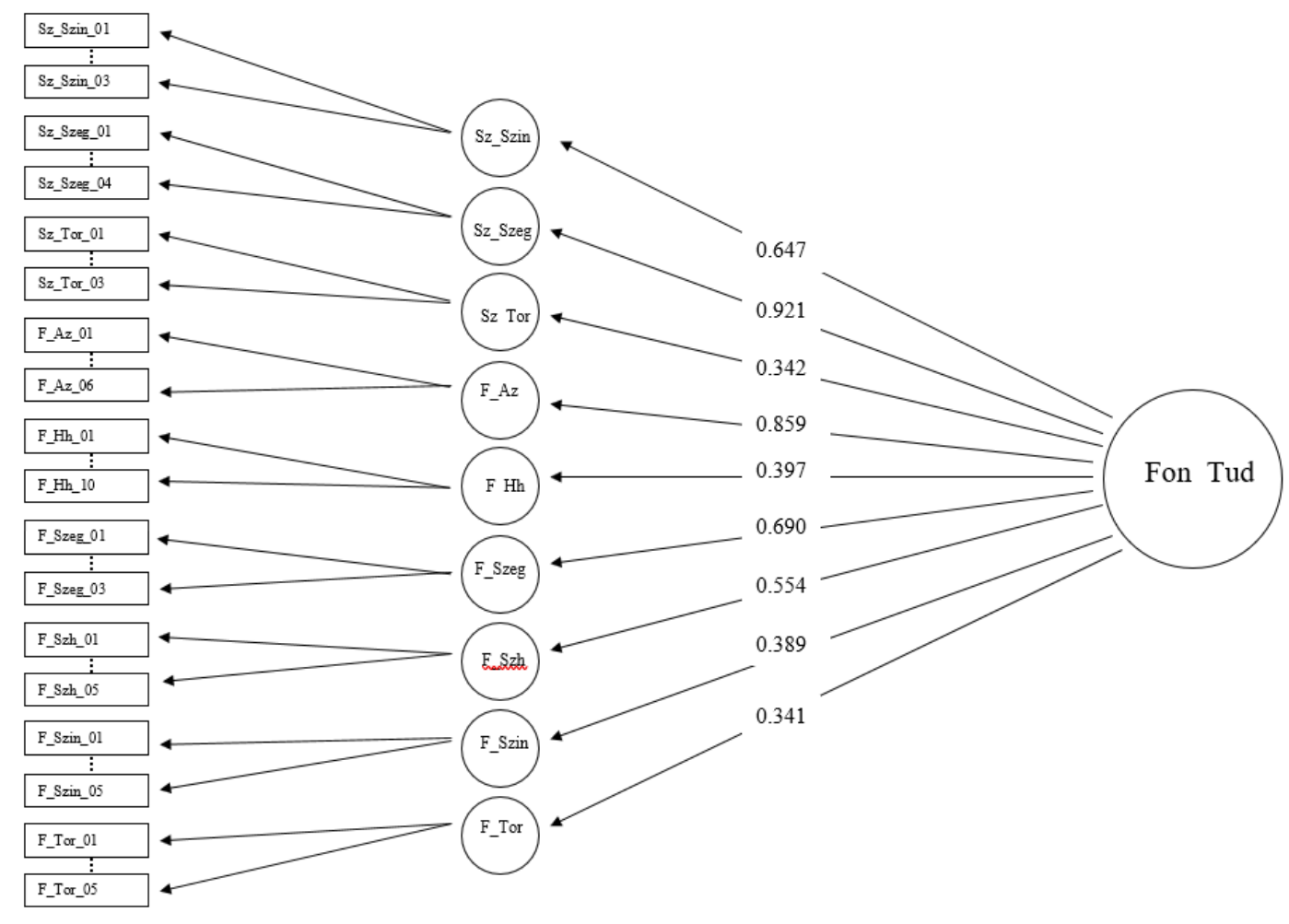

48. ábra

A fonológiai tudatosság teszt hierarchikus faktorelemzése az óvodai korcsoport körében, 1. modell

Fon_tud: fonológiai tudatosság; Sz_Szin: szótagszintézis; Sz_Szeg: szótagszegmentálás;

Sz_Tor: szótagtörlés; F_Szh: szókezdö hang azonositása; F_Szeg: fonémaszegmentálás;

F_Tor: fonématörlés; $F \_$szin: fonémaszintézis; $F_{-}$Az: fonémaazonositás; $F \_h h$ :

fonémaazonositás a hivóhang helyéne $\bar{k}$ meghatározásával 


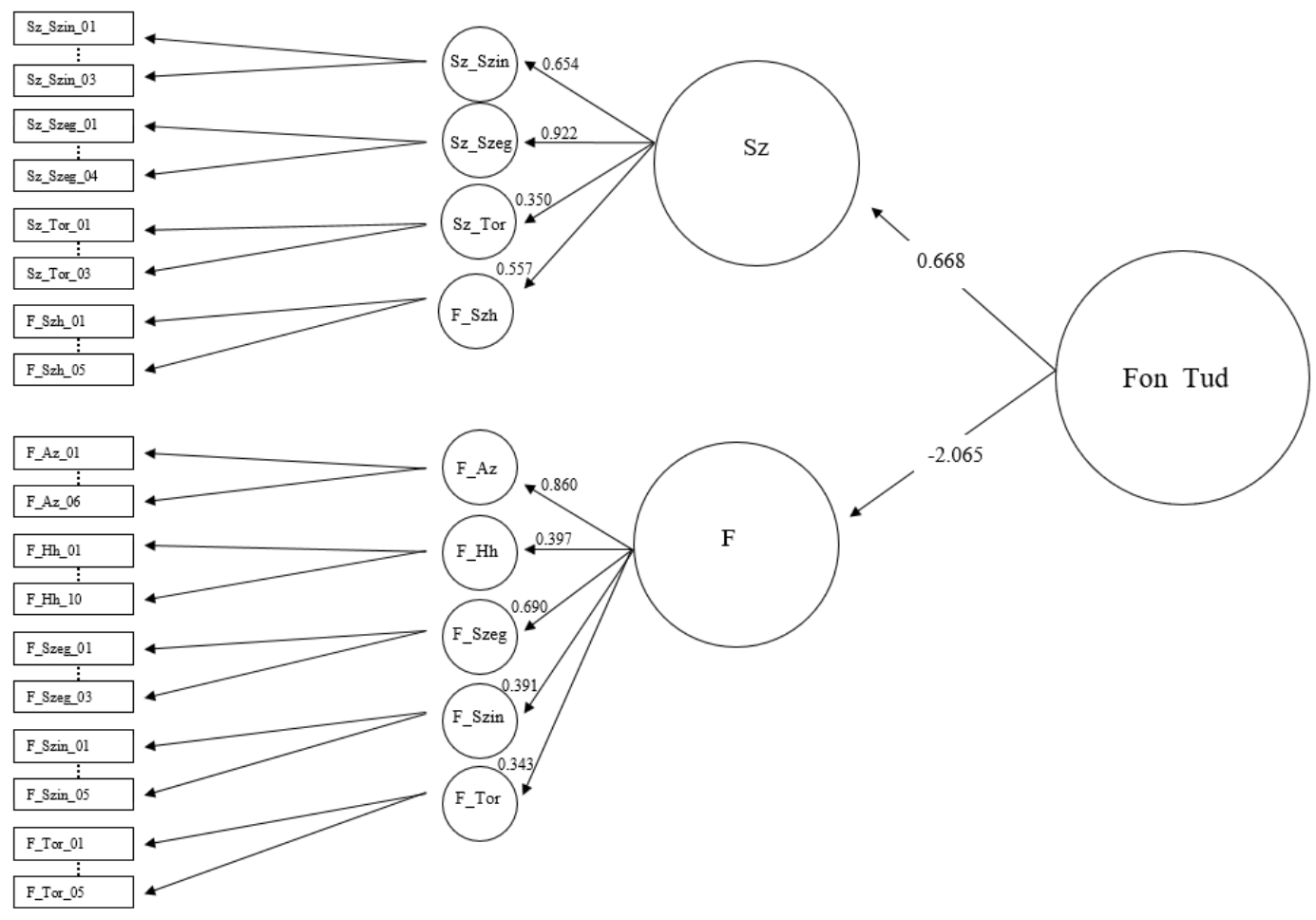

11. ábra

A fonológiai tudatosság teszt hierarchikus faktorelemzése az óvodai korcsoport körében, 2. modell

Fon_tud: fonológiai tudatosság; Sz: szótag; F: fonéma; Sz_Szin: szótagszintézis; Sz_Szeg: szótagszegmentálás; Sz_Tor: szótagtörlés; $F \_S z h$ : szókezdö hang azonositása; $F \_S z e g$ :

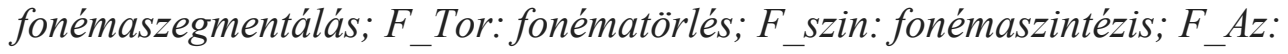
fonémaazonositás; $F \_$hh: fonémaazonositás a hívóhang helyének meghatározásával 


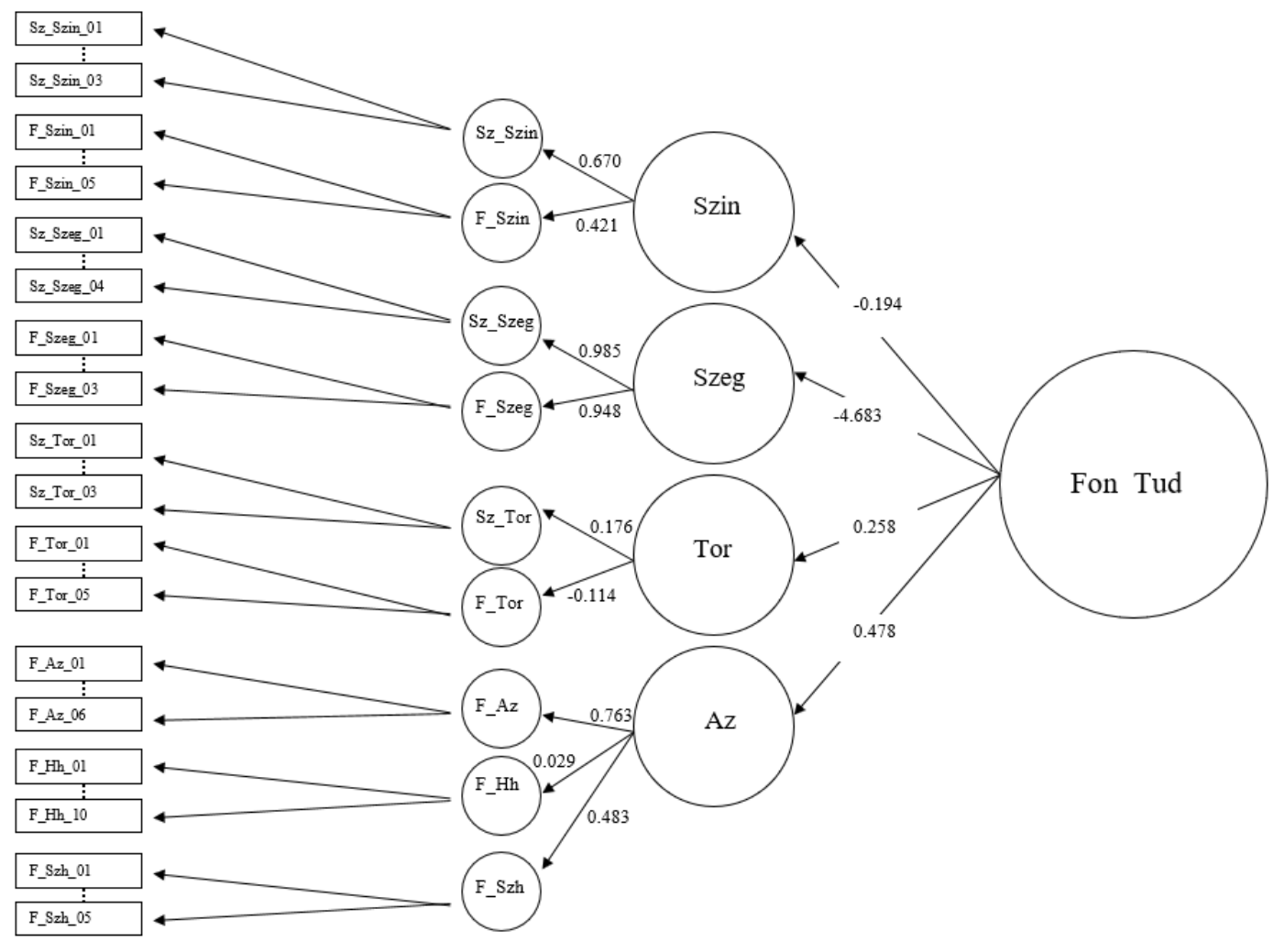

12. ábra

A fonológiai tudatosság teszt hierarchikus faktorelemzése az óvodai korcsoport körében, 3. modell

Fon_tud: fonológiai tudatosság; Sz_Szin: szótagszintézis; Sz_Szeg: szótagszegmentálás;

Sz_Tor: szótagtörlés; $F$ Szh: szókezdő hang azonositása; $F$ Szeg: fonémaszegmentálás; F_Tor: fonématörlés; $F \_$szin: fonémaszintézis; $F \_$Az: fonémaazonositás; $F \_h h$ : fonémaazonositás a hívóhang helyének meghatározásával; Szin: szintézis; Szeg: szegmentálás; Tor: törlés; Az: azonositás

A modell, hasonlóan az első osztályosok vizsgálata esetében, szintén az itemektől a fonológiai tudatosság, mint látens változóig építkezik. Az itemek faktorsúlyát a 10. melléklet tartalmazza. Bár a modellben megjelenő, a fonológiai tudatosság látens konstruktumához kapcsolódó faktorsúlyok értéke magasabb, mint az általános iskolai minta esetében kapottak, az óvodai tesztfelvételen alapuló modell esetében is a szegmentálás látens komponensének negatív faktorsúly elkülönül a másik három komponens értékeitől.

\section{2. 4. A gyermekek teszten elért teljesítményének vizsgálata}

A teszt megbízhatóságának és konstruktumának vizsgálata után a gyermekek teszten elért teljesítményét is vizsgálni kívánjuk. A gyermekek teszten nyújtott átlagteljesítményét és annak szórását az 48. táblázat mutatja be. A teljes teszten elért átlagos teljesítmény 50,16\%pont, ami 
szinte teljesen megfelel a pszichometrikailag kívánatos 50\%-nak. A teljes teszt szórása 16,89\%pont, ami jelzi a teszt megfelelő differenciáló erejét, másrészt annak ellenére, hogy elmarad az egyes feladattípusok szórásának értékétől, rámutat a gyermekek közötti nagy különbségekre. A táblázat értékei alapján látható, hogy a szótagszintézis feladatokon érték el a gyermekek a legmagasabb átlagértéket (84,86\%pont), míg a legalacsonyabb átlagteljesítmény a fonémaszegmentálás feladatokon (20,94\%pont) nyújtották. Szembetűnő, hogy a szókezdő hang azonosítása feladattípus szórása bizonyult a legnagyobbnak, tehát ezen a feladattípuson mutatkoztak meg leginkább az egyéni különbségek. Összességében elmondható, hogy a gyermekek közötti különbségek igen nagyok, melyet a feladattípusok szórásainak és az összteszt szórásának értéke is látványosan alátámaszt.

48. táblázat. A gyermekek teszten nyújtott teljesitményének átlaga és szórása

\begin{tabular}{ccccc}
\hline Feladattípus & Itemek száma & $\begin{array}{c}\text { Átlag } \\
\%\end{array}$ & $\begin{array}{c}\text { Szórás } \\
\%\end{array}$ & $\mathrm{~N}$ \\
\hline Szótagszintézis & 3 & 84,86 & 21,73 & 317 \\
Szótagszegmentálás & 4 & 27,92 & 35,32 & 317 \\
Szótagtörlés & 3 & 77,53 & 27,18 & 316 \\
Fonémaazonosítás & 6 & 46,00 & 30,41 & 316 \\
Fonémaazonosítás a hívóhang & 10 & 36,11 & 21,51 & 314 \\
helyének meghatározásával & 5 & 40,90 & 31,50 & 312 \\
Szókezdő hang azonosítása & 5 & 70,38 & 29,66 & 312 \\
Fonémaszintézis & 3 & 20,94 & 28,09 & 312 \\
Fonémaszegmentálás & 5 & 74,53 & 27,96 & 311 \\
Fonématörlés & $\mathbf{4 4}$ & $\mathbf{5 0 , 1 6}$ & $\mathbf{1 6 , 8 9}$ & $\mathbf{3 1 1}$ \\
\hline Teljes teszt & & & &
\end{tabular}

A gyermekek képességeinek árnyaltabb feltárását szolgálja a teljes és a részteszteken nyújtott teljesítmények eloszlásának vizsgálata (49. táblázat). A Kolmogorov-Smirnov teszt szerint minden eloszlás szignifikánsan eltér a normál eloszlástól. Az eloszlások jobbra aszimmetrikusak a szótagszintézis, szótagtörlés, fonémaszintézis, fonématörlés feladattípusok, valamint a teljes teszt esetében. A felsorolt résztesztek esetében a normál eloszláshoz képest több tanuló ért el magasabb teljesítményt. Az eloszlások lapultabbak a szótagszegmentálás, fonémaazonosítás, a szókezdő hang azonosítása, a fonémaszintézis, valamint a teljes teszt esetében, azaz a normál eloszláshoz képest alacsonyabb és egyenletesebb eloszlású volt a tanulók teljesítménye. 


\begin{tabular}{cccccc}
\hline Teszt megnevezése & $\begin{array}{c}\text { skewness } \\
\text { (szimmetria) }\end{array}$ & $\begin{array}{c}\text { kurtosis } \\
\text { (lapultság) }\end{array}$ & $\begin{array}{c}\text { Kolmogorov- } \\
\text { Szmirnov } \\
\text { teszt }\end{array}$ & df & $\mathrm{p}$ \\
\hline Szótagszintézis & $-1,37$ & 1,56 & 0,38 & 311 & $<0,01$ \\
$\begin{array}{c}\text { Szótagszegmentálás } \\
\text { Szótagtörlés }\end{array}$ & 0,90 & $-0,63$ & 0,31 & 311 & $<0,01$ \\
Fonémaazonosítás & $-1,01$ & 0,24 & 0,32 & 311 & $<0,01$ \\
Fonémaazonosítás a & 0,30 & $-1,18$ & 0,20 & 311 & $<0,01$ \\
hívóhang helyének & 0,71 & 0,23 & 0,16 & 311 & $<0,01$ \\
meghatározásával & & & & & \\
Szókezdő hang & 0,28 & $-1,00$ & 0,16 & 311 & $<0,01$ \\
$\quad$ azonosítása & $-0,85$ & $-0,16$ & 0,20 & 311 & $<0,01$ \\
Fonémaszintézis & 1,27 & 0,90 & 0,33 & 311 & $<0,01$ \\
Fonémaszegmentálás & $-1,05$ & 0,26 & 0,24 & 311 & $<0,01$ \\
$\quad$ Fonématörlés & $\mathbf{- 0 , 1 1}$ & $\mathbf{- 0 , 1 1}$ & $\mathbf{0 , 0 6}$ & $\mathbf{3 1 1}$ & $<\mathbf{0 , 0 1}$ \\
\hline Teljes teszt & & & & & \\
\hline
\end{tabular}

\section{2. 5. A gyermekek teljesítményének eloszlása az életkoruk és nemük szerint}

Az óvodás korcsoport mintaszervezése kapcsán már részben említésre került, hogy a mérésekbe, az óvodák vegyes csoportjai miatt, olyan gyermekek is bekerültek, akik koruk szerint adott vizsgálati évben nem válnak iskolakötelessé, tehát a vizsgálatot követő szeptember 1-jéig nem töltik be hatodik életévüket (Nemzeti Köznevelési Törvény (Nkt.) 45. §). Ezen gyerekek nem képezték a vizsgált mintánkat. Annak ellenére, hogy első említésre viszonylag homogénnek tủnhet a vizsgált korcsoport, mégis az iskolaérettség számos kritériuma mellett az életkor is csupán egyetlen tényező. Az óvodai vegyes csoportok kialakítása miatt a középső és nagycsoport elkülönítés sem mérvadó, valamint az is további vizsgálatot igényelne, hogy a gyermek melyik adott csoportot ismételné az óvodai elömenetel során. A mintában 2008 és 2010 között született gyermekek szerepelnek, ők azok, akik életkoruk szerint a vizsgálat évében iskolába léphetnek. Az 50. táblázat alapján látható, hogy legkevesebben a 2008-as gyermekek, míg legtöbben a 2010-es gyermekek szerepeltek a mintában. A 2008-as gyermekek a felvétel idejében már megközelítették vagy meghaladták 8. életévüket, a 2009-es gyermekek vagy évvesztesek voltak, vagy egyéb (egyelőre feltáratlan) okok miatt nem kezdték meg az általános iskolát. Fontosnak tartom megemlíteni, hogy a mintában szereplő egyik gyermek sem sajátos nevelési igényü. Az 51. táblázat alapján megállapítható, hogy legjobb átlagteljesítményt a 2009-ben született gyermekek értek el, míg a legnagyobb szórás értéket a 2010-es gyermekek esetében tapasztaltuk. Az évenkénti életkori osztályozás szerint szignifikáns különbség nem tapasztalható az életkor és az összteljesítmény tekintetében $(F(2,314)=2,80, p>0,05)$. 
50. táblázat. A gyermekek átlagéletkora és annak szórása a teszt rögzitésének idöpontjában

\begin{tabular}{cccc}
\hline Születési év & Átlagéletkor & Szórás & N \\
\hline 2008 & 7,06 & 0,12 & 6 \\
2009 & 6,16 & 0,36 & 148 \\
2010 & 5,40 & 0,49 & 163 \\
\hline Összesen & 5,79 & 0,59 & 317 \\
\hline
\end{tabular}

51. táblázat. A gyermekek teljesitményének átlaga és szórása a születési év függvényében

\begin{tabular}{cccc}
\hline Születési év & $\begin{array}{c}\text { Átlag } \\
(\%)\end{array}$ & $\begin{array}{c}\text { Szórás } \\
(\%)\end{array}$ & $\mathrm{N}$ \\
\hline 2008 & 49,61 & 22,43 & 6 \\
2009 & 52,52 & 16,16 & 148 \\
2010 & 48,02 & 17,16 & 163 \\
\hline
\end{tabular}

Mivel a gyermekek óvodáskori készség és képességfejlődése rendkívül gyors, és eltérő, ezért fontosnak tartottuk, hogy a születési félévek bontásával még árnyaltabb képet adjunk a különböző korcsoportú óvodás gyermekek teljesítményéröl. A teljesítmények féléves bontásban való tanulmányozását tovább indokolja, hogy maga, a gyermekek iskolakészültségét vizsgáló teszt is félévenkénti monitorozást javasol, feltérképezve ezzel a gyermekek rendkívül gyors és eltérő fejlődését. A minta féléves bontását, illetve a gyermek mintaelemszámát és teszten elért teljesítményét az 52. táblázat tartalmazza. A féléves bontás esetében sincs szignifikáns különbség az összteljesítmény tekintetében $(\mathrm{F}(4,312)=1,80, \mathrm{p}>0,05)$.

52. táblázat. A gyermekek teljesítményének átlaga és szórása a születési félév függvényében

\begin{tabular}{cccc}
\hline & $\begin{array}{c}\text { Átlag } \\
(\%)\end{array}$ & $\begin{array}{c}\text { Szórás } \\
(\%)\end{array}$ & $\mathrm{N}$ \\
\hline $2008 / 2$ & 49,61 & 22,43 & 6 \\
$2009 / 1$ & 53,72 & 16,29 & 36 \\
$2009 / 2$ & 52,16 & 16,16 & 112 \\
$2010 / 1$ & 49,11 & 16,66 & 108 \\
$2010 / 2$ & 45,86 & 18,07 & 55 \\
\hline
\end{tabular}

A nyelvi egység mérete, a müveleti és a résztesztenkénti bontás esetében a szótag szintü feladatok $(F(4,312)=3,55 p<0,01)$, a szegmentálási művelet $(F(4,312)=4,74 p<0,01)$ és a szótagszegmentálás részteszt $(\mathrm{F}(4,312)=4,09 \mathrm{p}<0,01)$ esetében tapasztalhattunk szignifikáns 
különbséget a korcsoportok között. A variancianalízis Levene-próbája alapján a Tukey’s-b post hoc elemzéseredményeit vettük figyelembe a szótag szintü feladatok $(\alpha=1,64 p>0,05)$, illetve a szegmentálás müveletének esetében $(\alpha=0,92$ p >0,05). A szótagszintü feladatok esetében a 2009 1. félévében született gyerekek szignifikánsan jobban teljesítettek, a szegmentálás feladatok esetében a 2008 2. félévi és 2009 1. félévi gyerekek között jelentkezett szignifikáns különbség, a 2009 1. félévében született gyerekek szignifikánsan jobban teljesítettek. A szótagszegmentálás feladatok esetében Dunnett's T3 post hoc elemzést alkalmaztuk $(\alpha=7,60$ p<0,01). A 2008 2. félévi gyermekek teljesítménye szignifikánsan különbözött a 2009 1. félévi és 2009 2. félévi gyermekektől is, illetve további különbség mutatható ki a 2009 2. és a 20101. félévében született gyermekek között. Mindkét esetben a 2009-ben születettek nyújtottan jobb teljesítményt.

Az óvodai korosztály esetében a teljes teszt és a nem közötti korrelációs együttható értéke $\mathrm{r}=0,07$, az összefüggés nem szignifikáns ( $>00,05)$ (53. táblázat). Mivel a korreláció pozitív értékü, ezért a tendencia a lányok előnyét mutatja. Az összteszttel való összefüggésen kívül vizsgáltuk a nyelvi egység mérete, a müveletek, valamint a résztesztek közti összefüggéseket is. A nyelvi egység nagysága szerinti tagolódás és a nemek között nem találtunk szignifikáns összefüggést, illetve ugyanez a tendencia rajzolódott ki a műveletek szerinti tagolódás esetében is. A fonológiai tudatosság fejlettségében szignifikáns különbség egyedül a fonémaszintézis feladattípus során mutatható ki a lányok javára (54. táblázat).

53. táblázat. A nem és résztesztek közti korrelációs együtthatók értékei, a vonatkozó szignifikancia értékek és a mintaelemszáma

\begin{tabular}{cccc}
\hline & $\mathrm{nem}$ & $\mathrm{p}$ & $\mathrm{N}$ \\
\hline Szótagszintézis & $-0,04$ & 0,53 & 317 \\
Szótagszegmentálás & 0,01 & 0,88 & 317 \\
Szótagtörlés & 0,03 & 0,64 & 316 \\
Fonémaazonosítás & 0,10 & 0,06 & 316 \\
Fonémaazonosítás a & & & \\
hívóhang helyének & 0,01 & 0,86 & 314 \\
meghatározásával & & & \\
Szókezdő hang & 0,06 & 0,29 & 312 \\
azonosítása & 0,14 & 0,01 & 312 \\
Fonémaszintézis & $-0,02$ & 0,07 & 312 \\
Fonémaszegmentálás & 0,05 & 0,37 & 311 \\
Fonématörlés & 0,07 & 0,21 & 316 \\
\hline Azonosítás & 0,09 & 0,11 & 317 \\
Szintézis & $-0,01$ & 0,93 & 317 \\
Szegmentálás & 0,05 & 0,40 & 316 \\
Törlés & 0,01 & 0,88 & 317
\end{tabular}




\begin{tabular}{cccc} 
Fonéma & 0,08 & 0,14 & 316 \\
\hline Teljes teszt & $\mathbf{0 , 0 7}$ & $\mathbf{0 , 1 9}$ & $\mathbf{3 1 7}$ \\
\hline
\end{tabular}

54. táblázat. A fonológiai tudatosság fejlettsége óvodáskorban

\begin{tabular}{|c|c|c|c|c|c|c|c|c|c|}
\hline \multirow{2}{*}{ Teszt megnevezése } & \multirow{2}{*}{ nem } & \multirow{2}{*}{$\mathrm{N}$} & \multirow{2}{*}{$\begin{array}{c}\text { Átlag } \\
(\%)\end{array}$} & \multirow{2}{*}{$\begin{array}{c}\text { Szórás } \\
(\%)\end{array}$} & \multicolumn{2}{|c|}{ Levene-teszt } & \multirow{2}{*}{$t$} & \multirow{2}{*}{ df } & \multirow{2}{*}{$\mathrm{p}$} \\
\hline & & & & & $\mathrm{F}$ & $p$ & & & \\
\hline \multirow{2}{*}{ Szótagszintézis } & fiú & 171 & 85,58 & 20,13 & \multirow{2}{*}{3,57} & \multirow{2}{*}{0,06} & \multirow{2}{*}{0,63} & \multirow{2}{*}{315} & \multirow{2}{*}{0,53} \\
\hline & lány & 146 & 84,02 & 23,56 & & & & & \\
\hline \multirow[t]{2}{*}{ Szótagszegmentálás } & fiú & 171 & 27,63 & 36,08 & \multirow[t]{2}{*}{0,08} & \multirow[t]{2}{*}{0,78} & \multirow[t]{2}{*}{0,16} & \multirow[t]{2}{*}{315,00} & \multirow[t]{2}{*}{0,88} \\
\hline & lány & 146 & 28,25 & 34,52 & & & & & \\
\hline \multirow{2}{*}{ Szótagtörlés } & fiú & 171 & 61,40 & 12,19 & \multirow{2}{*}{0,11} & \multirow{2}{*}{0,74} & \multirow{2}{*}{0,47} & \multirow{2}{*}{314,00} & \multirow{2}{*}{0,64} \\
\hline & lány & 146 & 60,73 & 12,80 & & & & & \\
\hline \multirow{2}{*}{ Fonémaazonosítás } & fiú & 170 & 43,33 & 29,59 & 005 & 090 & 106 & 21500 & $00 \Omega$ \\
\hline & lány & 146 & 49,43 & 30,97 & , & 0,02 & 1,00 & 15,00 &, 00 \\
\hline Fonémaazonosítás a & fiú & 169 & 35,92 & 22,35 & 120 & 026 & 018 & & \\
\hline meghatározásával & lány & 145 & 36,34 & 20,58 & (1, &, 20 & 0,10 & 10, 10 & , \\
\hline Szókezdő hang & fiú & 169 & 39,17 & 31,72 & 004 & 084 & 105 & 31000 & $0>9$ \\
\hline azonosítása & lány & 143 & 42,94 & 31,22 & & & & & \\
\hline Fonémaszintézis & fiú & 169 & 66,63 & 32,49 & 1243 & 000 & 250 & 30797 & 0.01 \\
\hline 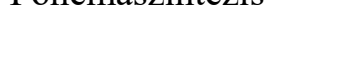 & lány & 143 & 74,83 & 25,31 & & 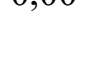 & & & \\
\hline Fonémaszegmentálás & fiú & 169 & 21,50 & 28,02 & 0,01 & 0,94 & 0,38 & 310,00 & 0,70 \\
\hline & lány & 143 & 20,28 & 28,26 & & & & & \\
\hline Eonómä̈̈rlóc & fiú & 168 & 73,21 & 28,61 & 050 & $0-14$ & 001 & 30523 & 027 \\
\hline 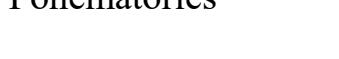 & lány & 143 & 76,08 & 27,19 & 0,37 & $0,4+4$ & $-0,91$ & ( & ונד, \\
\hline A ronocítóc & fiú & 171 & 38,43 & 20,30 & 000 & 007 & 126 & 31500 & 021 \\
\hline & lány & 146 & 41,32 & 20,37 & & & & J10,00 & \\
\hline Szintézis & fiú & 171 & 73,25 & 23,53 & 1,72 & 0,19 & $-1,61$ & 313,69 & 0,11 \\
\hline & lány & 146 & 77,31 & 21,43 & & & & & \\
\hline Sreamentólác & fiú & 171 & 24,90 & 24,27 & 086 & 036 & 000 & 31146 & 003 \\
\hline SLE gittintalas & lány & 146 & 24,66 & 23,04 & 0,00 & 0, 0 & 0,07 & $J 11,40$ & ני, \\
\hline Törlés & fiú & 171 & 67,98 & 20,70 & 1.37 & 0.24 & -0.84 & 31366 & 0.40 \\
\hline & lány & 146 & 69,35 & 19,65 & & & & & \\
\hline Szótag & fiú & 171 & 55,15 & 17,33 & 0,02 & 0,89 & $-0,15$ & 315,00 & 0,88 \\
\hline & lány & 146 & 54,73 & 17,86 & & & & & \\
\hline Fonéma & fiú & 170 & 46,14 & 18,68 & 0,00 & 1,00 & $-1,48$ & 315,00 & 0,14 \\
\hline & lány & 146 & 49,01 & 18,61 & & & & & \\
\hline Teljes teszt & fiú & 171 & 49 & 17,15 & & & $-1,32$ & 315,00 & 0,19 \\
\hline
\end{tabular}




\section{2. 6. A fonológiai tudatosság teszt és a géphasználat teszt összefüggése óvodás}

\section{korban}

Az óvodai teszteket tabletek segítségével töltötték ki a gyermekek, ezzel kivonva az egeret mint közvetítő perifériát és a kurzort mint a képernyőn megjelenő pozícionáló és vezérlő eszközt. A gyerekek közvetlenül a képernyő érintésével, ujjaik segítségével adtak választ.

A géphasználat teszten nyújtott teljesítmény 5,3\%-ban magyarázta a fonológiai tudatosság teszten nyújtott teljesítményt $(\mathrm{F}(1,315)=17,63, \mathrm{p}<0,01)(55$. táblázat). A két teszt közti kapcsolat árnyaltabb feltárásához segítséget adhat, ha a géphasználat teszt fonológiai tudatosság tesztben megjelenő típusfeladatainak kapcsolatát vizsgáljuk, így elemzéseink kitértek a géphasználat drag\&drop, tehát a vonszolás technikáját alkalmazó feladatok, valamit a kattintást kérő feladatok vizsgálatára is. A vonszolást kérő feladatok esetében csak a géphasználat és a fonológiai tudatosság tesztben fellelhető, kizárólag vonszolást kérő feladatok kapcsolatának feltárása került sor. Vonszolás esetében az összefüggés nem szignifikáns $(\mathrm{F}(1$, $310)=0,056, p>0,05)$, illetve maga a magyarázóerő is elhanyagolható. A kattintást kérő feladatok esetében a megmagyarázott variancia $6,25 \%(F(1,312)=20,23 \mathrm{p}<0,01)$.

55. táblázat. A géphasználat teszt és a fonológia tudatosság teszt összefüggésének vizsgálata az óvodás korosztály körében

\begin{tabular}{cccccc}
\hline & $\mathrm{r}$ & $\beta$ & $\mathrm{r} \beta^{*} 100$ & $\mathrm{p}$ & $\mathrm{r}^{2}$ \\
\hline Teljes teszt & 0,23 & 0,23 & 5,29 & $<0,01$ & 0,05 \\
Kattintás & 0,25 & 0,25 & 6,25 & $<0,01$ & 0,06 \\
Vonszolás & $-0,01$ & $-0,01$ & 0,01 & $>0,05$ & 0,00 \\
\hline
\end{tabular}

\section{3. A fonológiai tudatosság óvodás korosztály körében végzett vizsgálat eredményeinek összefoglalása}

Az óvodai mintavétel elemszáma lényegesen elmarad az eddigi online vizsgálatoktól, valamint a minta is megyeszékhelyi óvodákra korlátozódik. Ennek oka többrétű, hiszen egyrészt az óvodai tesztelés kisebb csoportokban valósul meg, a tesztelés során figyelembe kell venni az infrastrukturális korlátokat, valamint ez a tesztelési forma sokkal nagyobb mértékü 
empátiát, törődést és figyelmet követel meg a mérőbiztosok részéről. Ezen tényezők összessége merőben lassíthatja a tesztfelvételi folyamatot.

A teszt összességében megbízhatónak tekinthető, viszont az egyes résztesztek Cronbach$\alpha$ értéke elmarad a kívánatos határértéktől. Összességében elmondható, hogy a nyelvi egység mérete szerinti tagolódás esetében a szótagszintű feladatok (csupán 10 item) megbízhatósági mutatói alacsonynak, míg a fonémaszintü feladatok értékei megbízhatónak tekinthetők. A mérőeszköz feladatai, az óvodai mérések megbízhatósági mutatóinak tükrében, javításra, részleges újragondolásra szorulnak.

Az IRT elemzés szerint a feladatok nehézségi szintjének eloszlása a müveleti szintek szerint valósul meg, adataink szerint a legnehezebbnek a szegmentálás feladatok bizonyultak. A teszt belső konstruktumának vizsgálata során is arra a következtetésre jutottunk, hogy a müveletek szerinti tagolódás a mérvadó az óvodai mérőeszköz esetében is.

A gyermekek összességében a legalacsonyabb átlagteljesítményt a szegmentálás feladatokon érték el. A minta születési évenként és félévenkénti elkülönítésében is szembetűnő, hogy a legidősebb korosztály nyújtotta átlagosan a legalacsonyabb teljesítményt, míg a 2009es születésü gyermekek, akik a mérés idejében meghaladták hatodik életévüket, teljesítettek a legjobban.

Az óvodások esetében a megváltozott közvetítő médium miatt kiemelten fontos a médiahatás vizsgálata. A fonológiai tudatosság teszt és a géphasználat teszt között tapasztalható megmagyarázott variancia értéke megfelelő.

Összességében megállapítható, hogy a fonológiai tudatosság teszt első óvodai tesztelése fontos tanulságokat hordoz magában. Egyrészt bár a teszt összteszt szempontjából megbízható, mégis a feladatok újragondolására sarkallóak az alacsony megbízhatósági mutatók. Másrészt a megváltozott tesztkörnyezet, a tesztek és mérőbiztosok gyermekközpontúsága egy új, másfajta mérőbiztosi, tesztelési attitüdöt hordoz magában, melyben nemcsak a tesztelés, hanem a játékosság is szerepet kap. 


\section{A FONOLÓGIAI TUDATOSSÁG FEJLETTSÉGÉNEK VIZSGÁLATA AZ ÓVODA-}

ISKOLA ÁTMENET SORÁN

\section{1. A vizsgált minta és a két korosztályban rögzített közös itemek bemutatása}

Az óvoda-iskola átmenet közti különbségek feltárására két évfolyamon felvett tesztek közös itemeinek vizsgálata mellett döntöttünk. Az óvodai tesztet a 2015-ben rögzített fonológiai tudatosság teszttel vetettük össze. Az eredetileg, az első osztályosok körében rögzített teszt 1301 tanuló adatait tartalmazza, míg az óvodai mintavétel 311 gyermekét. A mintavétel további eltérése abban rejlik, hogy míg az óvodai minta kizárólag a csongrádi megyeszékhely óvodáit tartalmazza, addig az első osztályosok körében végzett vizsgálat országos mintán zajlott. Az adatok összehasonlíthatósága céljából kizárólag azon itemekkel dolgoztunk, melyek mindkét tesztben szerepeltek, így az összehasonlítás alapját képező teszt minden vizsgált területről tartalmazott itemeket. A minta eltérő elemszáma és területi tagolódása miatt úgy döntöttünk, hogy az első osztályosok körében leszükítjük a válaszadókat területi tagolódás alapján, és a mintaillesztés során csak csongrád megyei iskolák tanulóinak válaszaival dolgozunk. Így a mintaelemszáma is jelentősen csökken. A 7. fejezetben bemutatott óvodai minta összetételében és elemszámában változás nem történt. A mintához illesztett iskolai korosztály esetében 261 tanuló lépett be a fonológiai tudatosság tesztbe, és közülük 260an be is fejezték azt (56. táblázat) 
56. táblázat. Az óvodai és általános iskolai tesztfelvétel során rögzített közös itemek

\begin{tabular}{cccc}
\hline Feladattípus & Itemek száma & $\begin{array}{c}\text { N } \\
\text { óvoda }\end{array}$ & $\begin{array}{c}\text { N } \\
\text { első osztály }\end{array}$ \\
\hline Szótagszintézis & 3 & 317 & 261 \\
Szótagszegmentálás & 4 & 317 & 261 \\
Szótagtörlés & 2 & 317 & 261 \\
Fonémaazonosítás & 6 & 316 & 261 \\
Fonémaazonosítás a hívóhang helyének & 10 & 314 & 261 \\
meghatározásával & 5 & 312 & 260 \\
Szókezdő hang azonosítása & 5 & 311 & 260 \\
Fonémaszintézis & 3 & 312 & 260 \\
Fonémaszegmentálás & 5 & 311 & 260 \\
Fonématörlés & 7 & 317 & 261 \\
\hline Szegmentálás & 8 & 317 & 261 \\
Szintézis & 7 & 317 & 261 \\
Törlés & 21 & 317 & 261 \\
Azonosítás & 9 & 317 & 261 \\
\hline Szótag & 34 & 316 & 261 \\
Fonéma & $\mathbf{4 3}$ & $\mathbf{3 1 1}$ & $\mathbf{2 6 0}$ \\
\hline Teljes teszt & &
\end{tabular}

\section{2. A fonológiai tudatosság fejlettsége az óvoda befejező és az iskola kezdő szakaszában}

Az óvodai és iskolai korosztály teszten elért teljesítményét és annak összehasonlítását többféle szempont alapján vizsgáljuk. Célunk a teljesítménybeli különbségek minél árnyaltabb feltárása. A különbözőségek és az azonosságok megállapítására elsőként a két korosztály összteszten, nyelvi szinteken, müveleti szinteken, valamint részteszteken nyújtott teljesítményét hasonlítjuk össze. A két korcsoport teljesítménye között a törlés müvelete, valamint a hozzá tartozó résztesztek, a szótag- és fonématörlés esetében nem tapasztalható jelentős különbség, a többi esetben mindenhol szignifikáns különbséget fedezhetünk fel, minden esetben az első osztályosok nyújtottak szignifikánsan jobb teljesítményt (57. táblázat). Jordanidisz (2010) kismintás vizsgálatában 4-5, 5-6 és 6-7 éves óvodásokat vizsgált. Eredményei alátámasztották, hogy a törlés, mint manipulatív müvelet csupán hat éves kor körül kezd el fejlődni, így adataink alapján feltételezthető, hogy ebben a korcsoportban, illetve az olvasástanítás kezdetleges szakaszában ezért sem jelnnek meg jelentős különbségek a két közoktatási szintér gyermekei között. 
57. táblázat. A fonológiai tudatosság fejlettsége az óvoda befejezö és az iskola kezdö szakaszában

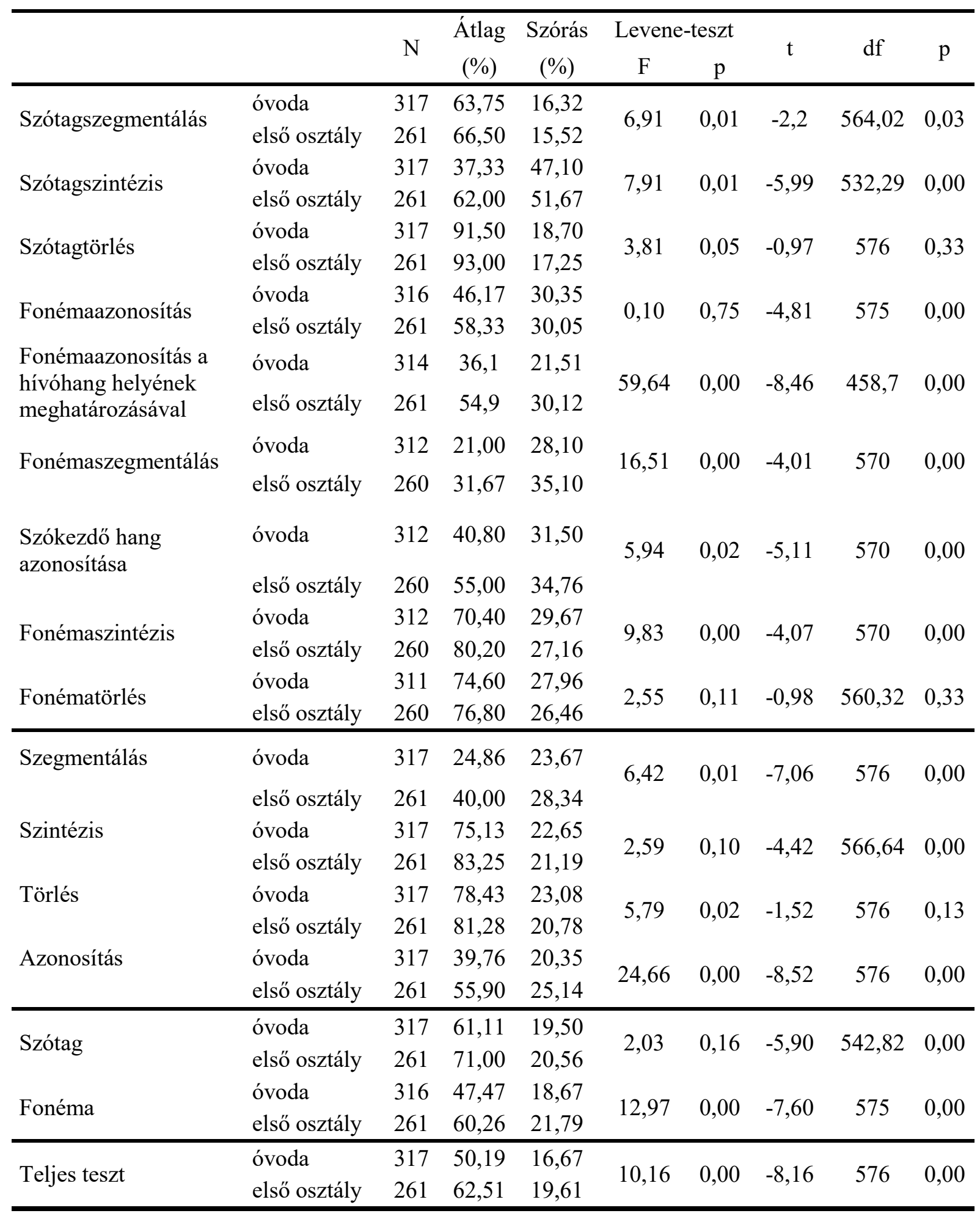




\section{3. A nemek szerinti különbségek vizsgálata}

A nem vizsgálata esetében megemlítendő, hogy az általános iskolai mintából 19 tanulóra vonatkozó adatunk hiányzunk, így a vizsgált 261 tanulóból 242 esetében rendelkezünk adattal. Az első osztályos válaszadók közül 120 fiú és 122 lány, míg az óvodai korosztály esetében 171 fiú és 146 lány töltötte ki a teszteket.

A nemek szerinti bontás esetében szignifikáns különbség fedezhető fel az összteszt (F(3, $555)=24,76 \mathrm{p}<0,01)$, a fonéma $(\mathrm{F}(3,554)=22,03 \mathrm{p}<0,01)$ és a szótag $(\mathrm{F}(3,555)=11,97 \mathrm{p}<0,01)$ mint nyelvi egység, az azonosítás $(\mathrm{F}(3,555)=27,96 \mathrm{p}<0,01)$, a szintézis $(\mathrm{F}(3,555)=7,38$ $\mathrm{p}<0,01)$ és a szegmentálás $(\mathrm{F}(3,555)=16,21 \mathrm{p}<0,01)$ műveletek, valamint a szótagszegmentálás $(\mathrm{F}(3,555)=12,61 \mathrm{p}<0,01)$, a fonémaazonosítás $(\mathrm{F}(3,554)=10,72 \mathrm{p}<0,01)$, a fonémaazonosítás a hanghelyének meghatározásával $(\mathrm{F}(3,552)=29,09 \mathrm{p}<0,01)$, a szókezdő hang azonosítása $(\mathrm{F}(3$, $549)=9,38 \mathrm{p}<0,01)$, a fonémaszegmentálás $(\mathrm{F}(3,549)=4,67 \mathrm{p}<0,01)$, a fonémaszintézis $(\mathrm{F}(3$, $549)=7,75 \mathrm{p}<0,01)$ résztesztek esetében. A törlés mint müvelet, a müveletet alkotó résztesztek (szótag- és fonématörlés), valamint a szótagszintézis feladatok esetében nem figyelhető meg szignifikáns különbség a nemek teljesítménye között sem óvodai, sem az általános iskolai mintán belül, illetve ugyanez tükröződik a két közoktatási szintér nemek szerinti összehasonlítása során is.

A felsorolt szignifikáns különbségek esetében, a fonémaszegmentálás részteszt kivételével, az a tendencia rajzolódik ki, mely szerint az általános iskolát megkezdő fiúk és lányok szignifikánsan jobb teljesítményt nyújtottak az óvodai, koruknál fogva iskolaérettnek tekinthető fiú és lány gyermekeknél. A fonémaszegmentálás részteszt esetében csak a lány tanulók teljesítménye bizonyult szignifikánsan jobbnak az óvodás fiú és lánygyermekeknél. Bár a különbség nem jelentős, az átlagteljesítmények alapján elmondható, hogy a szótagtörlés részteszt kivételével, ahol egyforma átlagteljesítményt nyújtottak az általános iskolás fiúk és lányok, minden esetben az első osztályos lány tanulók nyújtották a legjobb teljesítményt. A minta elemszáma, a kis itemszám, valamint egyéb háttérváltozók hiánya alapján nem egyértelműsíthető a lány tanulók előnye, de az ezirányú tendencia kimutatható, hasonlóan azonos online felületen, bár csak első osztályos tanulók körében végzett beszédhanghallást vizsgáló kutatáshoz (Csapó, Molnár, \& Nagy, 2015). 


\section{4. A mintán belüli korcsoportok fejlettségének vizsgálata}

Mivel a teljes minta vizsgálata során szignifikáns különbségeket fedeztünk fel az egyes életkorok elkülönítése esetében, ezért az óvoda-iskola átmenet közti, korcsoportonkénti különbségeket is vizsgálni kívántuk (58. táblázat). A mintaelemszáma nem mutat egyenletes eloszlást. A 2007-ben született gyermekek már nem jelennek meg az óvodás korcsoportban, viszont a 2008-as születésủek még hatan képviseltetik magukat, holott ez a korosztály már az iskola első évfolyamán is betöltötte a 7. életévet. Metszeti mintának tekinthetők a 2008-ban és 2009-ben született gyermekek. A két minta életkori csoportjainak összehasonlítása esetében is az a tendencia rajzolódik ki, hogy az iskolakezdés az életkor tekintetében kitolódik, hatodik életév betöltését követően, jelen mintából levont következtetések alapján is, csak kevesen kezdik meg az általános iskola első osztályát, mindez a vizsgált minta 23,85\%-át jelenti. Az óvodai korcsoportban, a gyermekek kora alapján, a 317 gyermekből 87 gyermeknek kellett volna megkezdenie az általános iskola első osztályát 2015 szeptemberében.

58. táblázat. A vizsgált minta átlagéletkora a teszt felvételének idejében

\begin{tabular}{ccccc}
\hline Közoktatás színtere & Születési év & Átlagéletkor & Szórás & N \\
\hline \multirow{3}{*}{ általános iskola } & 2007 & 7,35 & 0,49 & 18 \\
& 2008 & 6,74 & 0,44 & 181 \\
& 2009 & 6,01 & 0,21 & 62 \\
\hline \multirow{2}{*}{ óvoda } & 2008 & 7,06 & 0,12 & 6 \\
& 2009 & 6,16 & 0,36 & 148 \\
& 2010 & 5,40 & 0,49 & 163
\end{tabular}

A korosztályok teszten nyújtott teljesítménye alapján, a törlés müvelete $(F(5,572)=2,03$ $\mathrm{p}=0,07)$, valamint a részét képező szótag- $(\mathrm{F}(5,572)=1,25 \mathrm{p}=0,28)$ és fonématörlés $(\mathrm{F}(5$, $565)=1,56 \mathrm{p}=0,17$ ) résztesztek kivétel, minden esetben szignifikáns különbség mutatkozott (A korcsoportok teszteken nyújtott átlagteljesítményét és annak szórását az 59. táblázat tükrözi). A különbségek könnyebb áttekinthetősége miatt az eredmények értelmezését a korcsoportok tükrében három egységre bontottuk. Az első egység képviseli az óvodán belüli, a második az első osztályon belüli, míg a harmadik az óvoda és általános iskola közti különbséget.

Az óvodai korcsoportban a 2008-as születésü gyermekek a szótagszintézis (F(5, $572)=2,45 \mathrm{p}<0,05)$ részteszten nyújtottak szignifikánsan jobb teljesítményt, mint a 2009-es születésű gyermekek, a szótagszintü feladatok esetében $(F(5,572)=9,73 p<0,01)$, valamint a 
szegmentálás mủveletét $(\mathrm{F}(5,572)=13,83 \mathrm{p}<0,01)$ érintő feladatok esetében szignifikánsan jobban teljesítettek a 2009-es születésű gyermekek, 2010-es társaiknál.

Az általános iskolai korcsoporton belül szignifikáns különbségeket nem tapasztaltunk. Az óvodás gyermekek, valamint az általános iskolai tanulók a törlés müvelete, valamint a müvelethez tartozó résztesztek kivételével viszont minden esetben különbséget mutattak.

A teljes teszt tekintetében a 2008-as tanulók jelentősen jobb teljesítményt értek el, mint a 2009-es és 2010-es óvodás gyermekek $(\mathrm{F}(5,572)=16,06 \mathrm{p}<0,01)$. Legtöbb esetben (a fonémaszintü feladatok $(F(5,571)=13,96 p<0,01)$, az azonosítás $(F(5,572)=16,51 p<0,01)$, a szintézis $(F(5,572)=4,84 p<0,01)$ és a szegmentálás müvelete $(F(5,572)=13,83 p<0,01)$, a fonémaazonosítás $(\mathrm{F}(5, \quad 571)=5,50 \quad \mathrm{p}<0,01), \quad \mathrm{a}$ fonémaazonosítás a hanghelyének meghatározásával $(\mathrm{F}(5,569)=17,57 \mathrm{p}<0,01)$, a szókezdő hang azonosítása $(\mathrm{F}(5,566)=5,87$ $\mathrm{p}<0,01)$ és a fonémaszintézis $(\mathrm{F}(5,566)=4,11 \mathrm{p}<0,01)$ feladattípusok) a 2008-as születésü tanulók szignifikánsan jobban teljesítettek, mint a 2009-ben és 2010-ben született gyermekek. Bár háttérváltozók nékül egyértelműen nem lehet kijelenteni, de valószínűsíthető, hogy egyrészt a spontán fejlődés, másrészt az írás-olvasástanítás kezdeti szakasza hatással lehet az ezirányú teljesítmények alakulására. A szótagszintézis, szótagszegmentálás, valamint a fonémaazonosítás a hívóhang helyének meghatározásával résztesztek esetében azonos korcsoportok között is jelentős különbség figyelhető meg. A szótagszintézis és a szótagszegmentálás esetében a különbség a 2008-as születésüek esetében jelentkezik, a szótagszintézis esetében az óvodai, míg a -szegmentálás esetében az iskolai korosztály nyújtott szignifikánsan jobb teljesítményt. A fonémaazonosítás a hívóhang helyének meghatározásával részteszt esetében a 2009-es születésűek közti különbség jelentős, ebben az esetben a tanulók nyújtottak szignifikánsabb jobb teljesítményt.

59. táblázat. Az óvodás gyermekek és az iskolás tanulók teszten nyújtott átlagteljesitménye és annak szórása a születési év, a feladattípusok, a müveletek és az összteszt szempontjából

\begin{tabular}{|c|c|c|c|c|c|}
\hline A teszt megnevezése & $\begin{array}{l}\text { Születési } \\
\text { év }\end{array}$ & Közoktatás színtere & $\mathrm{N}$ & Átlag (\%) & $\begin{array}{l}\text { Szórás } \\
(\%)\end{array}$ \\
\hline \multirow[t]{7}{*}{ Szótagszintézis } & 2007 & Óvoda & & & \\
\hline & & Általános iskola & 18 & 88,89 & 19,80 \\
\hline & 2008 & Óvoda & 6 & 100,00 & 0,00 \\
\hline & & Általános iskola & 181 & 89,87 & 19,92 \\
\hline & 2009 & Óvoda & 148 & 86,49 & 19,76 \\
\hline & & Általános iskola & 62 & 85,48 & 23,08 \\
\hline & 2010 & $\begin{array}{l}\text { Óvoda } \\
\text { Általános iskola }\end{array}$ & 163 & 82,82 & 23,53 \\
\hline Szótagszegmentálás & 2007 & $\begin{array}{l}\text { Óvoda } \\
\text { Általános iskola }\end{array}$ & 18 & 40,28 & 38,48 \\
\hline
\end{tabular}




\begin{tabular}{|c|c|c|c|c|c|}
\hline & 2008 & Óvoda & 6 & 8,33 & 12,91 \\
\hline & & Általános iskola & 181 & 46,55 & 38,80 \\
\hline & 2009 & Óvoda & 148 & 35,98 & 38,27 \\
\hline & & Általános iskola & 62 & 48,39 & 39,17 \\
\hline & 2010 & Óvoda & 163 & 21,32 & 31,33 \\
\hline & & Általános iskola & & & \\
\hline Szótagtörlés & 2007 & Óvoda & & & \\
\hline & & Általános iskola & 18 & 94,44 & 16,17 \\
\hline & 2008 & Óvoda & 6 & 75,00 & 27,39 \\
\hline & & Általános iskola & 181 & 93,09 & 17,30 \\
\hline & 2009 & Óvoda & 148 & 91,89 & 18,49 \\
\hline & & Általános iskola & 62 & 92,74 & 17,76 \\
\hline & 2010 & Óvoda & 163 & 92,02 & 18,36 \\
\hline & & Általános iskola & & & \\
\hline Fonémaazonosítás & 2007 & Óvoda & & & \\
\hline & & Általános iskola & 18 & 52,78 & 31,96 \\
\hline & 2008 & Óvoda & 6 & 50,00 & 38,01 \\
\hline & & Általános iskola & 181 & 60,13 & 30,05 \\
\hline & 2009 & Óvoda & 148 & 48,65 & 30,27 \\
\hline & & Általános iskola & 62 & 54,57 & 29,44 \\
\hline & 2010 & Óvoda & 162 & 43,72 & 30,13 \\
\hline & & Általános iskola & & & \\
\hline Fonémaazonosítás a hívóhang & 2007 & Óvoda & & & \\
\hline & & Általános iskola & 18 & 37,78 & 27,98 \\
\hline & 2008 & Óvoda & 6 & 36,67 & 24,22 \\
\hline & & Általános iskola & 181 & 57,62 & 29,16 \\
\hline & 2009 & Óvoda & 148 & 36,49 & 21,25 \\
\hline & & Általános iskola & 62 & 52,10 & 31,99 \\
\hline & 2010 & Óvoda & 160 & 35,75 & 21,79 \\
\hline & & Általános iskola & & & \\
\hline Szókezdő hang azonosítása & 2007 & Óvoda & & & \\
\hline & & Általános iskola & 18 & 43,33 & 30,10 \\
\hline & 2008 & Óvoda & 6 & 36,67 & 32,04 \\
\hline & & Általános iskola & 181 & 56,13 & 34,71 \\
\hline & 2009 & Óvoda & 147 & 42,59 & 30,55 \\
\hline & & Általános iskola & 61 & 55,41 & 36,04 \\
\hline & 2010 & Óvoda & 159 & 39,50 & 32,45 \\
\hline & & Általános iskola & & & \\
\hline Fonémaszintézis & 2007 & Óvoda & & & \\
\hline & & Általános iskola & 18 & 71,11 & 34,45 \\
\hline & 2008 & Óvoda & 6 & 66,67 & 30,11 \\
\hline & & Általános iskola & 181 & 82,21 & 25,90 \\
\hline & 2009 & Óvoda & 147 & 69,66 & 29,46 \\
\hline & & Általános iskola & 61 & 76,72 & 28,09 \\
\hline & 2010 & Óvoda & 159 & 71,19 & 29,99 \\
\hline & & Általános iskola & & & \\
\hline Fonémaszegmentálás & 2007 & Óvoda & & & \\
\hline & & Általános iskola & 18 & 14,81 & 28,52 \\
\hline & 2008 & Óvoda & 6 & 22,22 & 40,37 \\
\hline & & Általános iskola & 181 & 33,70 & 34,96 \\
\hline & 2009 & Óvoda & 147 & 23,58 & 28,19 \\
\hline & & Általános iskola & 61 & 30,05 & 36,36 \\
\hline & 2010 & Óvoda & 159 & 18,45 & 27,47 \\
\hline & & Általános iskola & & & \\
\hline
\end{tabular}




\begin{tabular}{|c|c|c|c|c|c|}
\hline \multirow[t]{8}{*}{ Fonématörlés } & 2007 & Óvoda & & & \\
\hline & \multirow[b]{2}{*}{2008} & \multirow{2}{*}{$\begin{array}{l}\text { Általános iskola } \\
\text { Óvoda }\end{array}$} & 18 & 70,00 & 28,49 \\
\hline & & & 6 & 7667 & 32,04 \\
\hline & \multirow{3}{*}{2009} & Általános iskola & 181 & 78,45 & 25,95 \\
\hline & & Óvoda & 147 & 77,82 & 24,79 \\
\hline & & Általános iskola & 61 & 73,77 & 27,21 \\
\hline & \multirow[t]{2}{*}{2010} & Óvoda & 158 & 71,39 & 30,32 \\
\hline & & Általános iskola & & & \\
\hline \multirow[t]{8}{*}{ Szegmentálás } & \multirow[t]{2}{*}{2007} & Óvoda & & & \\
\hline & & Általános iskola & 18 & 29,37 & 27,49 \\
\hline & \multirow[t]{2}{*}{2008} & Óvoda & 6 & 14,29 & 22,13 \\
\hline & & Általános iskola & 181 & 41,04 & 28,21 \\
\hline & \multirow[t]{2}{*}{2009} & Óvoda & 148 & 30,60 & 24,26 \\
\hline & & Általános iskola & 62 & 40,32 & 28,75 \\
\hline & \multirow[t]{2}{*}{2010} & Óvoda & 163 & 19,89 & 22,02 \\
\hline & & Általános iskola & & & \\
\hline \multirow[t]{8}{*}{ Szintézis } & \multirow[t]{2}{*}{2007} & Óvoda & & & \\
\hline & & Általános iskola & 18 & 77,78 & 23,31 \\
\hline & \multirow[t]{2}{*}{2008} & Óvoda & 6 & 79,17 & 18,82 \\
\hline & & Általános iskola & 181 & 85,08 & 20,07 \\
\hline & \multirow[t]{2}{*}{2009} & Óvoda & 148 & 75,68 & 22,10 \\
\hline & & Általános iskola & 62 & 79,23 & 23,19 \\
\hline & \multirow[t]{2}{*}{2010} & Óvoda & 163 & 74,46 & 23,34 \\
\hline & & Általános iskola & & & \\
\hline \multirow[t]{8}{*}{ Törlés } & \multirow[t]{2}{*}{2007} & Óvoda & & & \\
\hline & & Általános iskola & 18 & 76,98 & 20,29 \\
\hline & \multirow[t]{2}{*}{2008} & Óvoda & 6 & 76,19 & 28,09 \\
\hline & & Általános iskola & 181 & 82,64 & 20,55 \\
\hline & \multirow[t]{2}{*}{2009} & Óvoda & 148 & 81,47 & 19,96 \\
\hline & & Általános iskola & 62 & 78,34 & 21,45 \\
\hline & 2010 & Óvoda & 163 & 75,72 & 25,25 \\
\hline & & Általános iskola & & & \\
\hline Azonosítás & 2007 & Óvoda & & & \\
\hline & & Általános iskola & 18 & 43,39 & 24,76 \\
\hline & 2008 & Óvoda & 6 & 40,48 & 26,04 \\
\hline & & Általános iskola & 181 & 57,98 & 24,70 \\
\hline & 2009 & Óvoda & 148 & 41,34 & 19,49 \\
\hline & & Általános iskola & 62 & 53,38 & 25,62 \\
\hline & 2010 & Óvoda & 163 & 38,30 & 20,93 \\
\hline & & Általános iskola & & & \\
\hline Szótag & 2007 & Óvoda & & & \\
\hline & & Általános iskola & 18 & 68,52 & 20,61 \\
\hline & 2008 & Óvoda & 6 & 53,70 & 8,36 \\
\hline & & Általános iskola & 181 & 71,33 & 20,46 \\
\hline & 2009 & Óvoda & 148 & 65,24 & 20,50 \\
\hline & & Általános iskola & 62 & 70,61 & 21,11 \\
\hline & 2010 & Óvoda & 163 & 57,53 & 18,10 \\
\hline & & Általános iskola & & & \\
\hline Fonéma & 2007 & Óvoda & & & \\
\hline & & Általános iskola & 18 & 48,86 & 19,95 \\
\hline & 2008 & Óvoda & 6 & 48,04 & 25,95 \\
\hline & & Általános iskola & 181 & 62,41 & 21,28 \\
\hline & 2009 & Óvoda & 148 & 49,15 & 17,66 \\
\hline & & Általános iskola & 62 & 57,35 & 22,71 \\
\hline
\end{tabular}




\begin{tabular}{|c|c|c|c|c|c|}
\hline & 2010 & $\begin{array}{l}\text { Óvoda } \\
\text { Általános iskola }\end{array}$ & 162 & 45,92 & 19,27 \\
\hline \multirow[t]{7}{*}{ Teljes teszt } & 2007 & Óvoda & & & \\
\hline & & Általános iskola & 18 & 52,97 & 18,34 \\
\hline & 2008 & Óvoda & 6 & 49,22 & 22,08 \\
\hline & & Általános iskola & 181 & 64,28 & 19,11 \\
\hline & 2009 & Óvoda & 148 & 52,51 & 15,93 \\
\hline & & Általános iskola & 62 & 60,13 & 20,61 \\
\hline & 2010 & $\begin{array}{l}\text { Óvoda } \\
\text { Általános iskola }\end{array}$ & 163 & 48,12 & 16,96 \\
\hline
\end{tabular}

\section{5. A feladatok nehézségi, és a tanulók képességszintjének összehasonlítása az óvodai és az általános iskolai tesztek esetében}

Mivel az óvodai adatgyüjtés a koruk szerint iskolaérett, az általános iskolai adatgyüjtés pedig az első osztályt megkezdett tanulókat érintette, ezért kíváncsiak voltunk, hogy a keresztmetszeti adatfelvétel tekintetében hogyan változik, illetve egyáltalán eltérő képet mutat-e a még óvodások és a már első osztályosok személy-itemtérképe (51. ábra). A bal oldali térkép az óvodai, míg a jobb oldali az általános iskolai tanulók adatait tükrözi. Az ábrák bal oldalán lévő skála a feladatok nehézségét, míg jobb oldala a tanulók képességszintjét jelzi. Az óvodai ábra bal oldalán lévő minden x 2.2, míg az általános iskolai ábra bal oldalán lévő minden x 1.6 tanulót reprezentál. Mindkét korosztály jellemzéséhez a Rasch modellt alkalmaztuk (Molnár, 2013), az EAP/PV reliabilitásmutató mind az óvodai $(0,84)$, mind az általános iskolai korcsoportnál $(0,89)$ megfelelő. Mindkét vizsgált korosztály esetében az itemek a képességskála széles spektrumát lefedik, egyaránt találhatunk a tanulók/gyermekek számára könnyü és nehéz itemeket. Mindkét korosztályban a legnehezebbnek (19) egy fonémaszegmentálás, míg legkönnyebbnek egy szótagszintézis feladat bizonyult. Az óvodai korcsoportban az itemek inkább a 0 képességszint köré (-1-1) intervallumban, míg az általános iskolai korosztályban inkább 1-es érték köré (0-1) közé csoportosulnak. A legnehezebb és legkönnyebb feladatok mindkét korcsoportban megegyeznek, az eloszlások tekintetében az általános iskolások teljesítménye inkább az egyes érték felé húz, mely azt jelzi, hogy számukra a tesztfeladatok könnyebbnek tekinthetök. Az óvodai korcsoport esetében találhatunk olyan gyermekeket, akik szinte hibátlanul válaszoltak a tesztkérdésekre, illetve mindkét korcsoportban találhatunk gyenge képességü válaszadókat is, de szembetűnő, hogy az általános iskolai korosztály esetében figyelhetjük meg a leggyengébb teljesítményt nyújtó tanulókat. A 7. és 15. számú item (mindkét item a fonémaazonosítást kér a hívóhang helyének meghatározásával), majdnem egy teljes értékkel nehezebb az óvodai korosztály számára, annak 
ellenére, hogy mindkét feladat magánhangzó előtti, szókezdő mássalhangzó meghatározását kéri a gyermekektől. Az iskolásoknál (1-2) szintek között megközelítőleg ugyanannyi tanuló található, mint (0-1) között, illetve az ábra alapján megállapítható, hogy (-1 és -2) szintek között a két poupuláció közel azonos számban képvisleteti magát. 
3

2

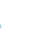

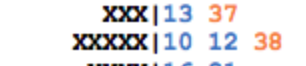

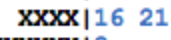

$\mathbf{x x x x x x} \mid 2$

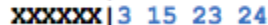

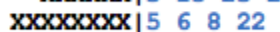

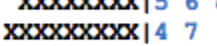

$\operatorname{XXXXXXXXXX|1420}$

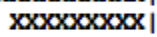

$\operatorname{xxxxxx|26}$

$\mathbf{x x x x x}$

$\operatorname{xxxxxxxx}$

xxxxxxx

$\mathrm{XXXXXXXX}$

$\operatorname{xxxxxx|}$

$\mathbf{X X X X X X | 2 7 3 3}$

$\mathbf{x x x}$

$\mathbf{X X X X | 4 0}$

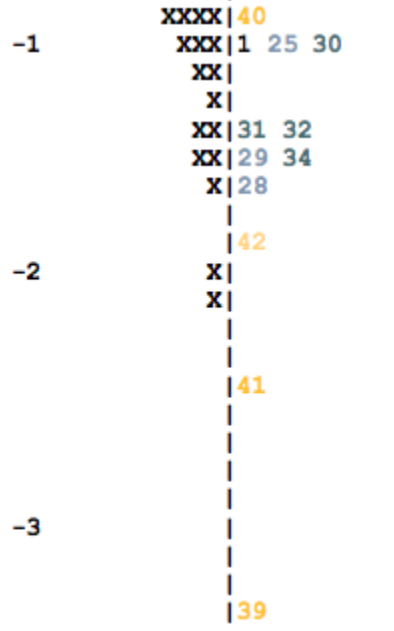

Óvoda
5

x।

3

|

$\mathrm{x}$

$\mathbf{x}$

1

$\mathbf{x x x} 19$

$\operatorname{xxxxx}$

2

$\mathbf{x x x}$

$\mathrm{xx \times x \times x \times x}$

$\operatorname{xxxxxx|}$

$\operatorname{xxxxxxx|17}$

$\operatorname{xxxxxxxx|~}$

$\operatorname{XXXXXXXXXX|18}$

$1 \quad \operatorname{xxxx\times x\times x\times x|9\quad 35}$

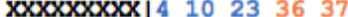

$\begin{array}{llll}\mathbf{X X X} X \mathbf{X} \times \mathbf{X X X} & 12 & 21 & 38\end{array}$

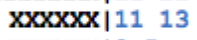

$\operatorname{xxxxxx} \mid 25$

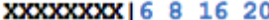

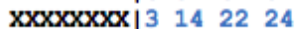

0

$\operatorname{xxxxxxxx}$

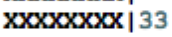

$\begin{array}{llll}x x x x \mid 7 \quad 15 \quad 26 & 43\end{array}$

$\mathbf{x x x}$ |

$\operatorname{xxxx}$

$\mathbf{X X X X} \mid 25 \quad 30$

$\mathbf{x x x} \mid 1$

$x \times 13134$

$-1$

$\mathbf{x x} \mid 2732$

XX|

$\mathbf{x x} \mid 2$

$\mathbf{x x} \mid$

x|29

$\mathrm{x}$

$-2$

I

$\mathrm{x}$ |

$\mathbf{x} \mid$

$\mathbf{x}$

$-3$

Iskola

51. ábra

Az óvodai korosztály és az általános iskola első osztályos tanulók körében rögzített fonológiai tudatosság teszt közös itemjeinek személy-item térképe.

A fonémaszintü feladatokat a színpaletta hideg, míg a szótagszintü feladatokat a paletta meleg árnyalatai jelzik. Így fonémaazonositást kék, a fonémaszegmentálást türkiz, a fonématörlést sötétzöld, a fonémaszintézist szürke, míg a szótagszegmentálást arany, szótagszintézist narancssárga és a szótagtörlést halvanysárga szinek jelölik. 


\section{6. Az óvodai és általános iskolai minta összehasonlítása során kapott eredmények összefoglalása}

Az óvodai és általános iskolai minta összehasonlítása során mintaillesztést végeztünk. Az így szürt gyermekek és tanulók száma megközelítette egymást. A tesztben a 2015-ös első osztályos mérés, illetve az óvodai tesztelés közös itemei jelentek meg, az így kapott teszt, mely az összehasonlítás alapját szolgálta, 43 itemet tartalmazott. A közoktatás két színtere közti teljesítménybeli különbség jelentkezett a törlés műveletének kivételével minden esetben, az iskolások javára. A nemenkénti vizsgálat során a szótagszintézis és a törlés müvelete, valamint az azt alkotó feladattípusok között nem tapasztalható jelentős különbség sem az óvodai és iskolai mintán belül, se a két minta között. Életkori szempontból a 2008-ban és 2009-ben született gyermekek közül kerül ki a metszeti mintánk, amely mindkét közoktatási színtéren megjelenik. A 2008-ban, és a 2009-ben született iskolások jobb teljesítményt nyújtanak a teszt rögzítése az azonos korú óvodásoknál, akik a vizsgálat idejében már szintén tanköteles korúnak számítanak. A személy-itemtérkép jelentős különbséget mutatott a korosztályok tekintetében. Az óvodai korosztály esetében a gyermekek többsége a (-1-1) szintek között találhatók, ugyanez a tanulók esetében a $(-1,2)$ szintek között jellemző. Az iskolai tanulók a képességskála tágabb tartományában mozognak. 5-5 fő kivételével az óvodai minta $(-2,2)$, míg az általános iskolai populáció (-2,3) szintek között találhatok. mindezen felül megállapítható, hogy ugyanazon feladatok bizonyultak a legnehezebbnek és a legkönnyebbnek a korcsoportok számára, illetve az is, hogy az első osztályos tanulók számára a teszt könnyebbnek bizonyult.

Összességében megállapítható, hogy az általános iskolát megkezdő tanulók a fonológiai tudatosság teszten jobb teljesítmény nyújtottak, viszont ezen különbségek nem minden esetben szignifikánsak. A mintaelemszáma, az egyes feladattípusok csekély itemszáma, valamint háttérváltozók hiányában további következtetések levonására nem vállalkoztunk. 


\section{9. ÖSSZEGZÉS, KÖVETKEZTETÉSEK}

A társadalomba való beilleszkedés, a sikeres olvasóvá nevelés egyik alappillére, az olvasási előképesség elsajátításának alapvető komponense a megfelelő fonológiai tudatossági szint korai elsajátítása. A képesség kutatásában újfajta, innovatív irányvonalat nyit a 21. század adta innovatív tesztfejlesztési lehetőség

Mind hazai, mind nemzetközi szinten számos kutatás, változatos mérőeszközökkel igyekszik feltárni a tanulók fonológiai tudatosság teszteken nyújtott teljesítményét, a résztesztek közti összefüggést, viszont a mérőeszközök nemcsak feladattípusukban, példaanyagukban, szerkezetükben, hanem értékelésükben, illetve a tesztrögzítési formájukban is eltérnek. Kevés a valóban olyan kutatás, mely a fonológiai tudatosságot önmagában, több részteszten keresztük, és nem egy-egy képességét, egyéb kognitív faktorok vagy dekódolási feladatok környezetében vizsgálja, és kevés az olyan mérőeszköz, mely ingyenesen, széles kör számára elérhető.

Kutatásunk célja egyrészt egy olyan online, a fonológiai tudatosság több részterületét lefedő online mérőeszköz fejlesztése volt, mely objektív és megbízható mérőeszközévé válhat az óvodai és általános iskolai korcsoportnak, másrészt pedig, hogy a kidolgozott mérőeszköz alkalmazhatóságát, valamint a gyermekek/tanulók teszten nyújtott teljesítményét vizsgáljuk a koruk szerint iskolaérett óvodai korosztály és az általános iskola első osztályos tanulói körében.

A tesztfejlesztés több szakaszban valósult meg. Az óvodai tesztelés technikai hátterének kialakítása még gyermekcipőben járt, így a fejlesztett fonológiai tudatosság teszt mérése és bemérése előtt kis itemszámú óvodai pilotvizsgálatokat hajtottunk végre, melyek nemcsak az óvodai mérések technikai feltételeinek feltárását és megismerését, hanem a kezdeti tesztek müködésére is rávilágítottak.

A fonológiai tudatosságot vizsgáló mérőeszközzel három mérési ponton dolgoztunk. A fonológiai tudatosság tesztet óvoda nagycsoportos, koruk szerint iskolaérett, valamint általános iskola első osztályos tanulók körében rögzítettük, majd a tesztben megjelenő kisebb nyelvi egység, a fonémaszintű müveletek kiemelésével, illetve egy feladat megjelenési és válaszadási módjának javításával fonématudatossági teszt rögzítésére került sor az általános iskola első osztályos tanulók körében. A számítógépes környezet mindhárom esetben megkönnyítette mind az adatfelvételt, mind az adatelemzést.

A kutatás eredetisége főként az óvodai tesztelés esetében jelentkezik. Egyedülálló törekvés, hogy két kutatócsoport, illetve a Szegedi Tudományegyetem két kara együttes hallgatói képzéssel hozza közelebb a pedagógushallgatókat az innovatív technika által 
biztosított lehetőséghez, valamint az is, hogy a kutatás elméletéhez hátteréhez és gyakorlati megvalósításához kapcsolódó kurzusok mind a két kar kurzuskínálatában szerepelnek. Ezáltal a hallgatók gyakorlati kurzusaikon keresztül megismerik az online tesztelés adta lehetőségeket, és valóban az innovatív, az digitális eszközelek megfelelően használni tudó pedagógusokká válnak. A kurzusok célja, hogy az innovatív szemlélet valóban a pedagógushallgatók részévé váljon. Természetesen a szemléletmód kialakítása nem azt jelenti hogy alkalmankként vagy kötelezően meg kell jelleniük az IKT-eszközöknek a pedagógusok mindennapjaiban, hanem azt, hogy ezt a lehetőséget ismertessük a hallgatókkal (Fáyné Dombi, Hódi \& Kiss, 2016; Kiss, 2016)

A kutatás korlátai egyrészt a szemtől szembeni és online környezet közti különbözőségeiben, illetve az eddig online, teljes osztályokat érintő tesztelés és óvodai tesztelés közti különbségekben mutatkoznak meg. A közoktatás két színtere közti infrastrukturális különbség, a közvetítő médium különbözősége, az óvodai mérések területi centralizáltsága, illetve mérőbiztosok felől megkövetelt viszonyulásmódok különbözősége jelentősen befolyásolja a vizsgálható minta mértékét, ezáltal megnehezítve a közoktatás két színterének összehasonlíthatóságát. Módszertanilag mégis újdonságnak tekinthető az online tesztelési forma, melynek elterjedése megkönnyítené az óvópedagógusok munkáját, valamint csökkentené nemcsak a gyermekek mérésére, tesztelésére szánt időt, hanem megkönnyítené a kapott adatok értelmezését, a gyermekek teljesítményének és fejlödésének nyomon követését. A mérési folyamatok felgyorsulásával, a játékos környezettel a gyermekek frusztrációja csökkenthető, a tesztelési folyamat objektívebbé válásával, a könnyen kinyerhető adatokkal pedig a pedagógusok munkája is könnyíthető.

\section{1. A hipotézisek igazolása}

A vizsgálat során felvetett hipotéziseink három fő szempont köré csoportosultak, egyrészt a teszt konstruktumát, másrészt a képesség fejlődését, harmadrészt pedig az egyéb, a teszten nyújtott teljesítményt befolyásoló tényezőket vettük górcső alá.

Mindhárom, a dolgozatban ismertetett teszt megbízhatóan méri a gyermekek képességét (H1) (Cronbach- $\alpha_{2015}=0,90$; Cronbach- $\alpha_{2016}=0,91$; Cronbach- $\left.\alpha_{\text {óvoda }}=0,84\right)$. Összességében a legalacsonyabb megbízhatósági mutatóval az óvodások körében mért teszt mutatkozott (Cronbach- $\alpha=0,82$ ), viszont megemlítendő, hogy a minta mindhárom mérési pontnál eltérő nagyságú volt, a 2016-os első osztályos mintában csak fonémaszintű feladatokat alkalmaztunk, valamint a teszt-item korrelációk vizsgálata után, illetve a szótag szintű feladatok elhagyása 
után, eltérő számú itemek kerültek eltávolításra. Míg a 2015-ös mintavételben 1301 tanuló lépett be a tesztbe, addig a 2016-os minta esetében 4338, az óvodások esetében pedig 317-en kezdték meg a tesztelést. Az össztesztek tekintetében a legfiatalabb és legkisebb mintaelemszámmal megjelenő óvodai korosztály esetében tapasztaltuk a legalacsonyabb Cronbach- $\alpha$ értéket. A résztesztek esetében szintén találhatunk alacsony megbízhatósági mutatóval rendelkezőket, melyek egyértelműen az adott itemcsoport újragondolását vonják maguk után. A teszt-item korrelációk vizsgálata, valamint a legalacsonyabb korrelációs értékekkel rendelkező itemek eltávolítása után, a 2015-ös adafelvétel esetében a leggyengébb résztesztnek a szótagtörlés, a 2016-os fonématudatosság teszt esetében a fonémaazonosítás, míg az óvodai adatfelvétel során a szótagszintézis feladattípúsok megbízhatósági mutatói mutatták a legalacsonyabb értéket.

A teszt konstruktumának vizsgálata $(\mathrm{H} 2)$ során elsőként a korrelációk vizsgálata mellett döntöttünk, majd megerősítő faktorelemzést alkalmaztunk. Az első osztályosok körében a nyelvi szintek között közepes $(\mathrm{r}=0,50, \mathrm{p}<0,01)$, a müveletek között gyenge vagy közepes kapcsolat áll fenn $(\mathrm{r}=0,37-0,54, \mathrm{p}<0,01)$. A teljes teszttel való kapcsolat estében müveletek közül leginkább a legnagyobb itemszámban megjelenő azonosítás $(\mathrm{r}=0,92, \mathrm{p}<0,01)$, míg a feladattípusok közül a fonémaazonosítás $(\mathrm{r}=0,70, \mathrm{p}<0,01)$, és a fonémaazonosítás a hang helyének meghatározásával $(\mathrm{r}=0,81, \mathrm{p}<0,01)$ típusú feladatok meghatározók. Mivel a korrelációs értékek vegyes képet mutattak, ezért a megerősítő faktorelemzések során öt modellt állítottunk fel, melyből végül a mutatói szerint fitnek tekinthető $\left(\chi^{2}=2043,286 \mathrm{df}=1044 \mathrm{p}<0,001\right.$ CFI=0,926 TLI=0,920 RMSEA=0,027), 9-dimenziós modell kirajzolása mellett döntöttünk $\left(\chi^{2}=2286,649 \mathrm{df}=1067 \mathrm{p}<0,001 \mathrm{CFI}=0,910 \mathrm{TLI}=0,905 \mathrm{RMSEA}=0,030\right)$. A három modelltípus felállítása után megállapíthatóvá vált, hogy a teszt belső konstuktumát a nyelvi egység méretétől függetlenül, a müveletek határozzák meg. Az óvodai minta esetében ugyanezen teszttel dolgoztunk. Az óvodások körében rögzített teszt esetében a korrelációs értékek némileg gyengébbek, viszont a feladattípusok és a teljes teszt tekintetében a fonémaazonosítás a hívóhang helyének meghatározásával típusú feladat $(\mathrm{r}=0,77 \mathrm{p}<0,05)$ mellett a szókezdő hang azonosítása $(\mathrm{r}=0,65, \mathrm{p}<0,05)$ és a fonémaszintézis $(\mathrm{r}=0,66, \mathrm{p}<0,05)$ mutatja az összteszttel való legerősebb kapcsolatot. A műveletek és a teljes teszt közti kapcsolat kimutatása során viszont a szegmentálás kivételével minden esetben (azonosítás, szintézis és törlés) erős korrelációs viszony fedezhető fel $(\mathrm{r}=0,71-0,88 \mathrm{p}<0,01)$. A CFA vizsgálat során szintén öt modellt állítottunk fel. Szintén a fit $\left(\chi^{2}=1045,874 \quad \mathrm{df}=866 \quad \mathrm{p}<0,001 \quad \mathrm{CFI}=0,916 \quad\right.$ TLI=0,906 RMSEA=0,026), 9-dimenziós modell kirajzolása mellett döntöttünk $\left(\chi^{2}=1088,160 \mathrm{df}=889\right.$ $\mathrm{p}<0,001 \mathrm{CFI}=0,905$ TLI=0,901 RMSEA=0,027). A 2015-ös fonológiai tudatosság teszt 
modelljének, valamint az óvodai tesztelés modelljének struktúrája azonos, valamint ugyanezen teszttel, másik, első osztályos mintán végzett vizsgálat eredményei szintén 9-dimenziós modellt állítottak fel (Kiss, Hódi, Tóth, \& B. Németh, 2016). A 2016-os általános iskolai mérés során a szótagszintű feladatok eltávolításra kerültek a tesztből, így a kapcsolatok vizsgálata a kizárólag a fonémaszintü feladatok köré csoportosult. A teljes teszt és a szintézis, szegmantálás és törlés müvelete $(r=0,66.0,72 \mathrm{p}<0,01)$, valamint a teljes teszt és a feladattípusok között zömében közepes, némely esetben magas korrelációs értéket tapasztalhattunk $(r=0,66-0,84, p<0,01)$. A mủvelet között föként közepes erősségü kapcsolat áll fenn, a legmagasabb korrelációs érték a fonémaazonosítás $(\mathrm{r}=0,73, \mathrm{p}<0,01)$ és a fonémaazonosítás a hívóhang helyének meghatározásával $(\mathrm{r}=0,84, \mathrm{p}<0,01)$ feladattípusok között tapasztalható, hasonlóan a 2015-ös mintához. Ennek értelmében a H2 hipotézisünk, melyet a nyelvi fejlődésre való modellek figyelembe vételével állítottunk fel (pl. Farrall, 2012), nem igazolható. Jelen, online teszt konstruktuma a nyelvi egység méretétől függetlenül, a müveletek meghatározó szerepére hívja fel a figyelmet mind az általános iskola első osztályában, mind az óvodás korú gyermekek körében. A hazai, a fonológiai tudatosság több, többek közt az általunk vizsgált részteket is magába foglaló vizsgálatban a résztesztek közti korrelációs érték kiszámítása nem jelent meg, ennek oka lehet a szemtől szembeni vizsgálat csekély mintaelemszáma (Jordanidisz, 2011).

A fonológiai tudatosság fejlődésére vonatkozó hipotéziseink (H3 és H4) vizsgálatára a 2015-ös első osztályos mintavétel, valamint az óvodai eredmények közös itemeit használtuk fel. A 8. fejezet összehasonlításában közel azonos mintaelemszámot, azonos itemeket alkalmaztunk, illetve figyelembe vettük a minta területi eloszlását is. Eredményeink rámutattak arra, hogy az első osztályos és az óvodai minta esetében, kizárólag a törlés müvelete köré csoportosuló feladatok esetében nincs szignifikáns különbség a két korosztály között. Jordanidisz (2010) munkájában megmelíti, hogy a törlés mủveletének kialakulása 6 éves kor köré tehető, ezért feltételezhető, hogy pont a vizsgált korosztály, tehát az óvoda-iskola átmenet által érintett korosztály különbségei is ebből adódhatnak. Továbbá figyelembe kell vennünk azt, hogy ezt a megállapítást csupán két szótagszintű és öt fonémaszintű feladat, valamint kis mintaelemszám bevonásával tettük meg, tehát az elméleti megállapítás alátámasztása további vizsgálatokat igényel. Az első osztályosok előnye mind az összteszt, mind a nyelvi szintek, mind az azonosítást, szintézist és szegmentálás kérő feladatok esetében megmutatkozott. A törlés müveletének vizsgálata során, valamint a mủvelet nyelvi szintenkénti bontása során is (szótag és fonémaszint), a feladatokon nyújtott átlagteljesítmény az első osztályosok esetében magasabb, viszont a két korosztály közti különbség nem szignifikáns. Így a H3 feltevésünk valóban helytálló, viszont a megmutatkozó különbség nem minden esetben számottevő. A 
vizsgált mintában a közoktatás két színtere, születési évek alapján, négy különböző életkori csoportot állítottunk fel. A legidősebb korosztály (2007-ben születettek) óvodai, illetve a legfiatalabb korosztály (2010-ben születettek) általános iskolai közegben nem jelennek meg. A különböző korcsoportok mintaelemszáma közti különbség jelentős, ezért a statisztikailag igazolható különbségeket a vonatkozó fejezet részletesen bemutatja, ezen adatok, az előző két szempont figyelembe vételével, a H4 igazolására vagy elvetésére nem tartottuk alkalmasnak.

A fonológiai tudatosság mérésére és háttérváltozóira vonatkozó hipotézisek a médiahatás mértékét (H5), valamint a nemek közti teljesítménykülönbséget (H6) hivatottak feltárni. A médiahatás vizsgálatára a géphasználat és a fonológiai tudatosság tesztek közti magyarázóerőt tártuk fel regresszióanalízis segítségével. A 2015-ös és az óvodai minta esetében kattintást és vonszolást kérő feladatok is megjelentek, ezért ezen műveleteket külön-külön is vizsgáltuk. A 2015-ös általános iskolai mintavétel asztali gépek segítségével valósult meg. A teljes géphasználat és a teljes fonológiai tudatosság teszt közti 9,3\%-os magyarázóerővel szemben $(\mathrm{F}(1,1299)=133,32, \mathrm{p}<0,01)$ csak kis mértékben maradt el a vonszolás müveletét kérő feladatok és a teljes teszt között tapasztalható 8,9\%-os érték $(F(1,1299)=126,74, p<0,01)$. A legkisebb megmagyarázott variancia $(2,9 \% ; \mathrm{F}(1,1299)=38,54, \mathrm{p}<0,01)$ a kattintást igénylő géphasználat és fonológiai tudatosság tesztfeladatok között jelentkezett. Az óvodai teszt esetében a közvetítő médium az érintőképernyős táblagép volt, így az egér mint a mozgást a számítógépre közvetítő hardvereszköz kiiktatásra került. Az óvodai tesztelés során így már 4\%-al kevesebb, 5,3\%-nyi magyarázóerő jelentkezett a géphasználat és a fonológiai tudatosság teszt között $(\mathrm{F}(1,315)=17,63 \mathrm{p}<0,01)$, viszont a kattintás müvelete esetében nagyobb, 6,25\%-nyi megmagyarázott variancia lépett fel a feladatok között $(F(1,312)=20,23, p<0,01)$. Az óvodai közegben a vonszolás kérő feladatok között nem tapasztaltunk szignifikáns összefüggést. A 2016-os vizsgálat során a fonématudatosság tesztben már csak kattintást igénylő feladatok jelentek meg, a közvetítő médiumok asztali számítógépek voltak. A teljes géphasználat teszt kisebb mértékben, 7,3\%-ban magyarázta a teszten nyújtott teljesítményt $(F(1,4179)=191,45$, $\mathrm{p}<0,01$ ), mint a 2015-ös mintavétel esetében, ahol ez az érték 9,3\%-volt, így a vonszolást igénylő feladatok eltávolítása hatásosnak tekinthető, a kattintás igénylő feladatok közti megmagyarázott variancia mértéke viszont 1,5\%-al nagyobb, mint a 2015-ös mintavétel esetében. Összességében megállapítható, hogy az össztesztek tekintetében a legkisebb megmagyarázott variancia az óvodai, táblagépes tesztelés során jelentkezett $(5,3 \%)$. A vonszolást igénylő feladatok kapcsán ilyen megállapítást nem tehetünk, hiszen az összefüggés az óvodai mintavétel esetében nem tekinthető szignifikánsnak, míg a kattintást igénylő feladatok esetében a 2015-ös mintavétel esetén tapasztaltuk a legkisebb magyarázóerőt (2,9\%). 
Rausch és Pásztor (2017) kutatásukban rámutattak arra, hogy a tesztek közti megmagyarázott variancia mértéke mögött további tényezők is megjelenhetnek. Kutatásukban ugyanazon gyermekeken rögzítették az iskolakészültségi teszt matematikatanulás előfeltétel-készségeire vonatkozó részt, melyet géphasználat teszt előzött meg, illetve a DIFER teszt elemi számolási részképességét vizsgáló szemtől szembeni tesztváltozatot. Bár céljuk az online matematika teszt validálása volt, összefüggést találtak a szemtől szembeni tesztfelvétel és a géphasználat teszt között is. Ezáltal feltételezték, és feltételezhetjük, hogy a tesztek összefüggés-vizsgálata során egyéb tényezők is közrejátszhatnak a megmagyarázott variancia mértékének feltárása során.

Az iskolaértettséggel szemben számos esetben hallhatjuk, hogy a lányok korábban érnek, fejlettségük megelőzi az azonos korú fiúk fejlettségét. A nemek közti különbségek vizsgálata az olvasási képességek terén is előtérbe kerül (Price-Mohr \& Price, 2017). Hazánkban az óvodásokkal (Nagy, 1980) és az általános iskolásokkal (Józsa, 2004) végzett vizsgálatok arra hívják fel a figyelmet, hogy bár hozzávetőlegesen 1,5 hónapnyi fejlettségbeli különbség tapasztalható a két nem között a lányok javára, ez pedagógiailag nem tekinthető számottevő fejlettségbeli különbségnek. A DIFER teszt beszédhanghallás résztesztjével végzett online vizsgálatok a lányok statisztikailag kimutatható előnyét bizonyították (Csapó, Molnár \& Nagy, 2015). Eredményeink mindhárom mintavételi ponton a lányok előnyét mutatják, az összefüggés viszont csak a 2016-os fonématudatosság teszt eredményei esetében szignifikáns.

\section{2. További kutatási lehetőségek}

A dolgozatban szereplő kutatások eredményei számos újabb irányvonalat jelöltek ki számunkra. A tesztváltozatok a fonológiai tudatosság csupán egy szeletét mérik, hiányterületként jelentkezik például a rímmel kapcsolatos feladatok adaptálása, az olvasás előkészségeit vizsgáló egyéb készségek bevonása, illetve az olvasás másik két kognitív faktorainak online mérése. A tanulók képességeinek hátterében meghúzódó további tényezők feltáráshoz a szülöi háttérkérdőív rögzítése elengedhetetlennek látszik, hiszen a szocioökonómiai státusz, családi háttérindex jelentősen meghatározhatja a gyermekek teljesítményét, illetve későbbi előmenetelük sikerességét (Carroll, Mundy, \& Cunningham, 2014; Elliott \& Grigorenko, 2014), másrészt egy olvasási nehézségekkel küzdő közeli hozzátartozó is befolyásolhatja a gyermek ezirányú fejlődését (Leavett, Nash, \& Snowling, 2014). A teszt továbbfejlesztése során indokolt lehet egy, a tesztelést megelőző hallásvizsgálat online rendszerbe történő integrálása/adaptálása is. 
Az egyes feladattípusok kis itemszámban jelennek meg, mellyel az egyes résztesztek teljesítménye jellemezhető, viszont a mélyebb összefüggések feltárására nem alkalmasak. Célszerü lenne az egyes feladattípusokon belül a 3. és 4. táblázatban megjelenő szempontok elkülönített vizsgálata is. Jelen kutatás a 3. táblázat első két szempontja köré (a nyelvi szintek és a művelet) csoportosítható egyértelmủen. Bár mérőeszköz tartalmazza a szógyakoriság, a szemantikai értelmezhetőség, valamint a szavak hosszúságának szempontjait, azaz a tesztek példaanyagát ezen szempontok mentén alakítottuk ki, mégis aaz egyes résztesztek, feladattípusok kis itemszáma nem teszi lehetővé, hogy a különböző szempontokat is statisztikai elemzések alá vonjuk. Az óvoda-iskola átmenet rendkívül szenzitív szakaszában szintén fontos lenne, ha sikerülne feltárni a keresett fonéma környezete, a fonémaszóbeli pozíciója, illetve a hang minsége szerinti szempontok jelentőségét, egymáshoz való viszonyát. A feladatok ezen szempont szerinti bővítése és ezáltal a lényegesen megnövekvő itemszám viszont hatalmas terhet róna a vizsgált gyermekekre. A gyermekek képességszintjének felállításához megoldást nyújthat az adaptív tesztek kialakítása, melyhez megfelelő alapot nyújthatnak az eddigi vizsgálatok során kapott személy-item térkép eredményei.

Szintén további kutatási lehetőségként tárul elénk a vizsgált, főként óvodai populáció fejlesztési módszertanának feltárása. Carlisle (1990) megállapítása nyomán, melyben kifejti, hogy a gyermekek teljesítményét onset-rhyme típusú feladatok esetében jobban meghatározhatja a feladat típusa, mint a valóban megjelenő nyelvi tudás, mindenképpen integrálni kellene a hazai gyakorlatba, és a vizsgált populáció esetében megvizsgálni, hogy a tesztelés időszakát megelőzően milyen típusú gyakorlófeladatok jelentek meg a foglalkozások során. 


\section{KÖSZÖNETNYILVÁNÍTÁS}

Köszönettel tartozom Csapó Benőnek, témavezetőmnek, a Neveléstudományi Doktori Iskola vezetőjének, hogy szakmai és emberi iránymutatásával támogatta disszertációm létrejöttét.

Köszönöm Molnár Gyöngyvérnek, hogy lehetőséget biztosított és szabad kezet adott az online rendszer használatára, hozzáértő szakmai iránymutatásával támogatta az innovatív feladatok létrejöttét.

Köszönöm Fáyné Dombi Alice-nek, hogy mind szakmailag, mind emberileg támogatta a mérések létrejöttét, ezáltal segítő együttmüködésben összekapcsolhatóvá vált a kutatás elméleti és gyakorlati oldala.

Köszönöm Nyitrai Ágnes és Szili Katalin házi opponenseim építő javaslatait, segítő tanácsait.

Köszönöm az Oktatáselméleti Kutatócsoport, a Képességfejlődés Kutatócsoport, a Szegedi Tudományegyetem Juhász Gyula Pedagógusképző Kar Tanító- és Óvóképző Intézetének munkatársainak, valamint lektorainknak elméleti és gyakorlati segítségét, a közös tesztfejlesztésben vállalt szerepüket.

Köszönöm Szeged Megyei Jogú Város Óvodáinak közel 5 éves együttmüködését.

Köszönettel tartozom az Oktatáselméleti Kutatócsoport kutatásszervezőinek az általános iskola minta megszervezésében, valamint hallgatóimnak és kollégáimnak az óvodai mérések lebonyolításában nyújtott segítségükért. 


\section{IRODALOM}

Adams, M. J., Foorman, B. R., Lundberg, I., \& Beeler, T. (1998). Phonemic awareness in young children: A classroom curriculum. Baltimore: Brookes.

Adams, M. J., Treadway, J., \& CTB/McGraw-Hill. (2000). Fox in a Box: An Adventure in Literacy. Monterey, CA: Author

Alibali, M. \& DiRusso A. (1999). The function of gesture in learning to count: more than keeping track. Cognitive Development, 14(1), 37-55.

Andrews, J. F., \& Wang, Y. (2014). The qualitative similarity hypothesis: research synthesis and future directions. American Annals for the Deaf, 159(4). doi: 10.1353/aad.2014.0028

Baddeley, A. D., Thomson, N., \& Buchanan, M. (1975). Word length and the structure of short term memory. Journal of Verbal Learning and Behavior, 14, 575-589.

Bailet, L. L., Repper, K., Murphy, S., Piasta, S., \& Zetter-Greeley, C. (2013). Emergent literacy intervention for prekindergarteners at risk for reading failure: Years 2 and 3 of a multiyear study. Journal of Learning Disabilities, 46, 133-153. doi: 10.1177/0022219411407925

Barbour, K., Keafer, K., \& Scott, K. (2003). Sounds of Speech. Phonological Processing Activities. Norfolk: NILD.

Berninger, V. W. (2001). Process Assessment of the Learner: Test Battery for Reading and Writing. San Antonio, TX: Psychological corporation.

Beschorner, B. \& Hutchison, A. (2013). iPads as a literacy teaching tool in early childhood. International Journal of Education in Mathematics, Science and Technology, 1, 16-24.

Blachman, B. A. (1994). What we have learned from longitudinal studies of phonological processing and reading, and some unanswered questions: A response to Torgesen, Wagner, \& Rashotte. Journal of Learning Disabilities, 27, 287-291.

Blomert, L. \& Csépe, V. (2012): Az olvasástanulás- és mérés pszichológiai alapjai. In B. Csapó \& V. Csépe (Eds.), Tartalmi keretek az olvasás diagnosztikus értékeléséhez. Budapest: Nemzeti Tankönyvkiadó.

Bradley, L. \& Bryant, P. E. (1983). Categorizing sounds and learning to read - a causal connection. Nature, 301, 419-421. 
Brady, S. A., Braze, D., \& Fowler, C. A. (Eds). (2011). Explaining individual differences in reading: Theory and evidence. New York: Psychology Press.

Brady, S. A., Shankweiler, D., \& Mann, V. (1983). Speech perception and memory coding in relation to reading ability. Journal of Experimental Child Psychology, 53, 345-376.

Bruce, D. J. (1964). The analysis of word sounds by young children. British Journal of Educational Psychology, 34(2), 158-170.

Bruinsma, R. (2003). The Joy of Language. Colorado Springs, Colorado: Purpusful Design.

Campbell, R. \& Butterworth, B. (1985). Phonological dyslexia and dysgraphia in a highly literate subject: a developmental case with associated of phonemic processing and awareness. Quarterly Journal of Experimental Psychology, 37A, 435-475.

Carlisle, J.F. (1991). Questioning the psychological reality of onset-rime as a level of phonological awareness. Phonological processes in literacy. A tribute to Isabelle Y. Liberman, S.A. Brady D.P. Shankweiler (eds.), Hillsdale (NJ):Lawrence Erlbaum, 85-95.

Carroll, J., Mundy, I., \& Cunningham, A. (2014). The roles of family history of dyslexia, language, speech production and phonological processing in predicting literacy progress. Developmental Science, 17(5), 727-742. DOI:10.1111/desc.12153.

Carson, K. L, Gillon, G. T., \& Boustead, T. M. (2013). Classroom phonological awareness instruction and literacy outcomes in the first year of school. Language, Speech, and Hearing Services in Schools, 44(2), 147-160.

Castles, A. \& Coltheart, M. (2004). Is there a causal link from phonological awareness to success in learning to read? Cognition, 91(1), 77-111.

Catts, H. W., Fey, M. E., Zhang, X., \& Tomblin, J. B. (2001). Estimating the risk of future reading difficulties in kindergarten children: A research-based model and its clinical implementation. Language, speech, and hearing services in schools, 32, 38-50.

Chappell, J. C., Stephens, T. L., Kinnison, L., \& Pettigrew, J. D. (2009). Educational diagnosticians' understanding of phonological awareness, phonemic awareness, and reading fluency. Assessment for Effective Intervention, 35(1), 24-33.

Chard, D. J. \& Dickson, S. V. (1999). Phonological awareness: instructional and assessment guidelines. Intervention in School and Clinic, 34(5), 261-270. 
Cooper, D. H., Roth, F. P., \& Speece, D. L. (2002). The contribution of oral language skills to the development of phonological awareness. Applied Psycholinguistics, 23(3), 399-416.

Crystal, D. (2003). A nyelv enciklopédiája. Budapest, Osiris.

Cuetos, F., Martínez-García, C., \& Suárez-Coalla, P. (2018). Prosodic Perception Problems in Spanish Dyslexia. Scientific Studies of Reading, 22(1), 41-54.

Cummings, K. D., Otterstedt, J., Kennedy, P. C., Baker, S. K., \& Kame'enui, E. J. (2011). DIBELS Data System: 2009-2010 Percentile Ranks for DIBELS 6th Edition Benchmark Assessments (Technical Report 1102). Eugene, OR: University of Oregon, Center on $\begin{array}{llll}\text { Teaching and from } & \text { Learning. }\end{array}$ https://dibels.uoregon.edu/research/techreports/\#dibels

Cunningham, A. J. \& Carroll, J. M. (2013). Early predictors of phonological and morphological awareness and the link with reading: Evidence from children with different patterns of early deficit. Applied Linguistics, 36(3), 509-531.

Csapó B., Józsa K., Steklács J., Hódi Á., \& Csíkos Cs. (2012). A diagnosztikus olvasás mérések részletes tartalmi kereteinek kidolgozása: elméleti alapok és gyakorlati kérdések. In B. Csapó \& V. Csépe (Eds.), Tartalmi keretek az olvasás diagnosztikus értékeléséhez (pp189-218). Budapest: Nemzeti Tankönyvkiadó.

Csapó, B., Molnár, G., \& Nagy, J. (2014). Computer-based assessment of school readiness and early reasoning. Journal of Educational Psychology, 106(3), 639-650. doi: $10.1037 / \mathrm{a} 0035756$

Csapó, B., Molnár, Gy., \& R. Tóth, K. (2008). A papír alapú tesztektől a számítógépes adaptív tesztelésig: a pedagógiai mérés-értékelés technikájának fejlődési tendenciái. Iskolakultúra, 18(3-4), 3-16.

Csépe, V. (2006). Az olvasó agy. Budapest: Akadémiai Kiadó.

Csépe, V. (2013). Olvasás, olvasási zavar és a fejlődő agy. Pszichológia, 33(1), 1-14.

Csépe, V. (2014). Az olvasás rendszere, fejlödése és modelljei. In V. Csépe (Ed.), Pszicholingvisztika (pp. 339-370). Budapest, Akadémiai Kiadó.

Csépe, V., Győri, M., \& Ragó, A. (2008, Eds.). Általános pszichológia 3. - Nyelv, tudat, gondolkodás. Budapest: Osiris. 
Deacon, S. H. (2012). Sounds, letters and meanings: The independent influences of phonological, morphological and orthographic skills on early word reading accuracy. Journal of Research in Reading, 35(4), 1-20.

Duff, F. J., Hulme, C., Grainger, K., Hardwick, S. J., Miles, J. N., \& Snowling, M. J. (2014). Reading and language intervention for children at risk of dyslexia: a randomised controlled trial. Journal of Child Psychology and Psychiatry, and Allied Disciplines, 55(11), 1234-1243. http://doi.org/10.1111/jcpp.12257

Elliott, J. \& Grigorenko, E. (2014). The dyslexia debate. New York: Cambridge University Press.

Ellis, N. C. \& Hennelly, R. A. (1980). A bilingual word-lenght effect: implications for intelligence testing and the relative ease of mental calculation in Welsh and English. British Journal of Psychology, 71, 43-51.

Ellis, R. (2009). Implicit and explicit learning, knowledge and instruction. In R. Ellis, S. Loewen, C. Elder, R. Erlam, J. Philp, \& H. Reiders (Eds.) Implicit and Explixit knowledge in second language learning and teaching (pp 3-25). Bristol: Multilingual Matters.

Farrall, M. L. (2012). Reading assessment: linking language literacy and cognition. New Jersey: Wiley. doi: 10.1002/9781118092668

Fáyné, Dombi. A., Hódi, Á., \& Kiss, R. (2016). IKT az óvodában: kihívások és lehetőségek. Magyar Pedagógia, 116(1), 91-117.

Fazekasné Fenyvesi, M. (2000). A beszédhanghallás kritériumorientált fejlesztése. Új Pedagógiai Szemle, 50(7-8), 279-284.

Flynn, J. (2001). Predictive Reading Profile. East Moline, IL: LinguiSystems.

Foormann, B. R., Fletcher, J. M., Francis, D. J., Carlson, C. D., Chen, D. T., Mouzaki, A., et al. (2002). Texas Primary Reading Inventory -2002-2003. Houston: Center for Academic and Reading Skills, University of Texas- Houston Health Science Center \& University of Houston.

Furnes, B. \& Samuelsson, S. (2010). Predicting reading and spelling difficulties in transparent and opaque orthographies: A comparison between Scandinavian and US/Australian children. Dyslexia, 16, 119-142. 
Geary, D. (1995). Reflections of evolution and culture in children's cognition: Implications for mathematical development and instruction. American Psychologist, 50(1), 24-37.

Gillon G. (2002). Follow-up study investigating the benefits of phonological awareness intervention for children with spoken language impairment. International Journal of Language and Communication Disorders. 37, 381- 400.

Gillon, G. T. (2004). Phonological Awareness: From Research to Practice. New York: The Guilford Press.

Good, R. H., \& Kaminski, R. A. (Eds.) (2002). Dynamic indicators of Basic Early Literacy Skills - Six Edition [Online]. Retrieved from http://dibels.uoregon.edu

Goswami, U. (2002). Phonolgy, reading development and dyslexia: a cross-linguistic perspective. Annals of Dyslexia, 52(1), 141-163.

Goswami, U. (2003). Phonology, learning to read and dyslexia: A cross-linguistic analysis. In V. Csépe (Ed.) Dyslexia. Different Brain, Different Behaviour. New York: Kluwer Academic.

Gósy, M. (1995/2006). GMP-diagnosztika. A beszédészlelés és a beszédmegértés folyamatának vizsgálata, fejlesztési javaslatok. Budapest: Nikol Kkt.

Göncz, L. (2003). A metanyelvi képességek fejlődése egynyelvü és kétnyelvű gyerekeknél. Alkalmazott nyelvtudomány, 3(2), 5-20.

Graham, S., Harris, K.R. \& Adkins, M. (2018). The impact of supplemental handwriting and spelling instruction with first grade students who do not acquire transcription skills as rapidly as peers: a randomized control trial. Reading \& Writing. Retrieved from http://www.readcube.com/articles/10.1007/s11145-018-9822-0

Graves, M. F., Juel, C., \& Graves, B. B. (1998). Teaching Reading in the 21st Century. Needham Heights:Allyn and Bacon.

Hatcher, P. J., Hulme, C., \& Ellis, A. W. (1994). Ameliorating early reading failure by integrating the teaching of reading and phonological skills: the phonological linkage Hypothesis. Child $\quad$ Development, 65(1), $\quad 41-57 . \quad$ DOI: 10.1111/j.14678624.1994.tb00733.x

Hatcher, P. J., Hulme, C., Miles, J. N. V., Carroll, J. M., Hatcher, J., Gibbs, S., \& Snowling, M. J. (2006): Efficacy of small group reading intervention for beginning readers with 
reading-delay: A randomized controlled trial. Journal of Child Psychology and Psychiatry, 47(8), 820-827.

Hayes, L., \& Flanigan, K. (2014). Developing word recognition. New York: Guilford Press

Hsuan, C., Tsai, H., \& Stainthorp, R. (2018). The role of phonological and orthographic awareness in learning to read among Grade 1 and 2 students in Taiwan. Applied Psycholinguistics, 39(1), 117-143.

Inverzinni, M. \& Meier, J. (2002a). PALS 1-3: Phonological Awareness Literacy Screening 2002-2003. Charlottesville: Curry School of Education, University of Virginia Press.

Inverzinni, M. \& Meier, J. (2002b). PALS 1-3: Phonological Awareness Literacy Screening 2002-2003 technical reference. Charlottesville: Curry School of Education, University of Virginia Press.

Jordanidisz, Á. (2009). A fonológiai tudatosság fejlődése az olvasástanulás időszakában. Anyanyelvpedagógia, 4. Retrieved from http://www.anyanyelvpedagogia.hu/cikkek.php?id=222

Jordanidisz, Á. (2010). A gyermekek fonológiai tudatosságának fejlődése 4-6 éves korban. Papre presented at the 4. Alkalmazott Nyelvészeti Doktorandusz Konferencia, Abstract retrieved from http://www.nytud.hu/alknyelvdok10/proceedings10.pdf

Jordanidisz, Á. (2011). A kétnyelvű gyermek olvasástanulásának és fonológiai tudatosságának kapcsolata. Gyógypedagógiai Szemle, 3-4. Retrieved from https://www.prae.hu/prae/gyosze.php?menu_id=102\&jid=37\&jaid=543

Józsa, K. (2004). Az első osztályos tanulók elemi alapkészségeinek fejlettsége: Egy longitudinális kutatás első mérési pontjai. Iskolakultúra, 14(11), 3-16.

Józsa, K., Kiss, R., Nyitrai, Á., Steklács, J., Szenczi, B., \& Tóth, D. (2015). Az olvasásszövegértés pszichológiai dimenziójának online diagnosztikus értékelése. In B. Csapó, J. Steklács, G. Molnár (Eds.), Az olvasás-szövegértés online diagnosztikus értékelésének tartalmi keretei (pp 33-103). Budapest: Oktatáskutató és Fejlesztő Intézet (OFI).

Józsa, K., Steklács, J. , Hódi, Á., Csíkos Cs., Adamikné Jászó, A., Molnár, E. K., Nagy Zs., \& Szenczi, B. (2012). Detailed framework for the diagnostic assessment of reading. In B. Csapó \& V. Csépe (Eds.) Framework for diagnostic assessment of reading (pp 215-305). Budapest: Nemzeti Tankönyvkiadó. 
Juhász, V. \& Kálló, V. (2017). A szótagtudatosság fejlesztése óvodás-, illetve kisiskoláskorban. Anyanyelv-pedagógia, 10(3). DOI: 10.21030/anyp.2017.3.3 Retrieved from http://www.anyanyelv-pedagogia.hu/img/keptar/2017_3/Anyp_X_2017_3_3.pdf

Juhász, V. \& Radics, M. (2017). Ujjtudatosság és számolásfejlesztés óvodás-, illetve kisiskoláskorban. Új Pedagógiai Szemle, 11-12, 50-72.

Kamhi, A. G. \& Catts, H. W. (1986). Toward an understanding od developmental language and reading disorders. Journal of Speech and Hearing Disorders, 51, 337-347.

Karmeenui, E. J. \& Simmons, D. (1990). Designing Instructural Strategies. The Prevention of Academic Learning Problems. Columbus, Ohio: Merrill Publishing Company.

Kas, B., Lőrik, J., M. Bogáth, R., Sz. Vékony, A., \& Sz. Mályi, N. (2015). SZÓL-E? Szürőeljárás az óvodai logopédiai ellátáshoz. Székesfehérvár: Logotech.

Kassai, I. (1999). Szótagtudat és olvasástanulás. In I. Kassai, (Ed.) Szótagfogalom szótagrealizációk (pp 153-166). Budapest: MTA Nyelvtudományi Intézet.

Kassai, I. (2001). Metanyelvi tudatosság és olvasási képesség. In B. Csapó (Ed.) 1. Országos Neveléstudományi Konferencia. Program. Tartalmi összefoglalók (pp 304). Budapest: MTA Pedagógiai Bizottság.

Kassai, I. (2006). Fonetika. In F. Kiefer (Ed.), Magyar nyelv (pp. 789-834). Budapest: Akadémiai Kiadó

Kiss, R. \& Patai, J. (2015a). The impact of the first school years on children's phoneme identification and verbal comprehension skills. Paper presented at the BCCCD 2015 Budapest CEU Conference on Cognitive Development. Budapest: Central European University.

Kiss, R. \& Patai, J. (2015b). Possibilities of technology-based assessment in kindergarten and early school age. In Cs. Csíkos \& Z. Gál (Eds.), X3III. Pedagógiai Értékelési Konferencia - 13th Conference on Educational Assessment. Program; Előadás-összefoglalók Program; Abstracts (pp. 117). Szeged: SZTE BTK Neveléstudományi Doktori Iskola

Kiss, R. (2015). Az olvasás korai szakaszának online diagnosztikus mérési lehetőségei. In E. Fazekas, A. Benő, \& B. Zsemlyei (Eds.), Többnyelvűség és kommunikáció KeletKözép-Európában: A XX4IV. Magyar Alkalmazott Nyelvészeti Kongresszus előadásai (pp. 53-59). Kolozsvár: Erdélyi Múzeum-Egyesület. 
Kiss, R. (2016). Innovatív óvópedagógus-képzés a Szegedi Tudományegyetem Juhász gyula Pedagógusképző Kar Tanító - és Óvóképző Intézetében. In A. Dombi \& M. Dombi (Eds.), Érték és nevelés, (pp. 265-272). Szeged: Szegedi Egyetemi Kiadó Juhász Gyula Felsőoktatási Kiadó

Kiss, R., Hodi, A., \& Török, T. (2015). Linguistic Factors Influencing Hungarian Students' Phonemic Identification From Grades 1 to 4. In Toward Justice: Culture, Language, And Heritage In Education Research And Praxis (pp 308). Washington: American Educational Research Association.

Kiss, R., Hódi, Á., Tóth, E., \& B. Németh, M. (2016). Egy magyar nyelvü fonológiai tudatosság teszt reliabilitásának és validitásának vizsgálata. In a. Zsolnai \& L. Kasik (Eds.), XVI. Országos Neveléstudományi Konferencia. Program és absztaktkötet, (pp. 255). Szeged: SZTE Neveléstudományi Intézet.

Klicpera, C. \& Gasteiger-Klicpera, B. (1995). Psychologie der Lese- und Schreibschwierigkeiten. Entwicklung, Ursachen, Förderung. Weinheim, Beltz: Psychologie Verlags Union.

Konza, D. (2011). Phonological awareness. Research into practice. Understanding the reading $\begin{array}{lll}\text { process. } & \text { Retrieved from }\end{array}$ https://www.ecu.edu.au/_data/assets/pdf_file/0009/663696/SA-DECS_Understanding-the-Reading-Process.pdf

Konza, D. (2014): Teaching Reading: Why the "Fab Five" should be the "Big Six". Australian Journal of Teacher Education, 39(12), 152-169.

Leavett, R., Nash, H. M., \& Snowling, M. J. (2014). Am I dyslexic? Parental self-report of literacy difficulties. Dyslexia, 20(4), 297-304. doi: 10.1002/dys.1481.

Leong, C.K. \& Sheh, S. (1982). Knowing about language - Some evidence from readers. Annals of Dyslexia, 32,149-161.

Logan, J. A. R., Schatschneider, C., \& Wagner, R. K. (2011). Rapid serial naming and reading ability: the role of lexical access. Reading and Writing, 24(1), 1-25.

Lonigan, C. J., Purpura, D. J., Wilson, S. B., Walker, P. M., \& Clancy-Menchetti, J. (2013). Evaluating the components of an emergent literacy intervention for preschool children at risk for reading difficulties. Journal of Experimental Child Psychology, 114, 111-130. doi: 10.1016/j.jecp2012.08.010 
Lonigan, C., Schatschneider, C., \& Westberg, L. (2008). Results of the national early literacy panel research synthesis: Identification of children's skills and abilities linked to later outcomes in reading, writing, and spelling. In NELP: Developing early literacy: Report of the National early literacy panel (pp. 55-106). Washington: National Institute for Literacy.

Lonigan, C.J., Burgess, S.R., \& Anthony, J.L. (2000). Development of emergent literacy and early reading skills in preschool children: Evidence from a latent-variable longitudinal study. Developmental Psychology, 36(5), 596-613.

Lőrik J. \& Kászonyiné Jancsó, I. (2009). A fonológiai tudatosság fejlesztése és hatása az írott nyelv elsajátítására. In K. Marton (Ed.), Neurokognitív fejlödési zavarok vizsgálata és terápiája. Példák a bizonyitékon alapuló gyakorlatra (pp. 11-42). Budapest: ELTE Eötvös Kiadó.

Lőrik, J., \& Májercsik, E. (2015). Iskolába lépö és 1. osztályos gyermekek néhány olvasásiirási alapkészségének vizsgálata. Tesztfelvételi, pontozási és értékelési útmutató. Budapest: Educatio Társadalmi Szolgáltató Nonprofit Kft.

Lőrik, J. (2006). A gyermeki fonológiai tudatosság megismeréséről. Beszédgyógyitás, 17(2), 32-60. Retrieved from http://www.beszed.hu/repository/2124.pdf

Lundberg, I., Frost, J., \& Peterson, O-P. (1988). Effects of an extensive program for stimulating phonological awareness in preschool children. Reading Research Quarterly, 23, $263-284$.

Marcel, A. J. (1980). Conscious and unconscious perception: experiments on visual masking and word recognition. Cognitive Psychology, 15(2), 197-237.

Marinelli, C. V., Romani, C., Burani, C., \& Zoccolotti, P. (2015). Spelling acquisition in English and Italian: A cross-linguistic study. Frontiers in Psychology, 6, 1843. doi:10.3389/fpsyg.2015.01843

Marsh, J., Yamada-Rice, D., Bishop, J., Lahmar, J., Scott, F., \& Plowman, L. (2015). Exploring play and creativity in pre-schoolers' use of apps: Technology and play. Economic and Social Research Council. Retrieved from http://www.techandplay.org/tap-mediapack.pdf

Mayer C., \& Trezek, B. J. (2014). Is reading different for deaf individuals? Reexamining the role of phonology. American Annals of the Deaf, 159(4), 359-371. 
McKenney, S., \& Voogt, J. (2012). Teacher design of technology for emergent literacy: An explorative feasibility study. Australasian Journal of Early Childhood, (37), 4-12.

Meixner, I. \& Justhné Kéry, H. (1967). Az olvasástanitás pszichológiai alapjai. Budapest: Akadémiai Kiadó.

Meixner, I. (1993). A dyslexia prevenció, reedukáció módszere. Budapest, Bárczi Gusztáv Gyógypedagógiai Tanárképző Főiskola.

Meixner, I. (2012). Játékház, Képes olvasókönyv. Nemzeti Tankönyvkiadó.

Molnár, E. (1989). Leíró magyar hangtan. Budapest, Tankönyvkiadó.

Molnár, G. \& Magyar, A. (2015). A számítógép alapú tesztelés elfogadottsága pedagógusok és diákok körében. Magyar Pedagógia, 115(1), 49-66.

Molnár, G. (2013). A Rasch modell alkalmazási lehetöségei az empirikus kutatások gyakorlatában. Budapest: Gondolat Kiadó.

Molnár, G. (2015). A képességmérés dilemmái: A diagnosztikus mérések (eDia) szerepe és helye a magyar közoktatásban. Géniusz Mühely: A magyar tehetségsegítő szervezetek szövetsége (MATEHETSZ) kiadványsorozata, 15(2), 16-29. Retrieved from http://tehetseg.hu/sites/default/files/mentorok_es_mentoraltak/nwp15.pdf.

Molnár, Gy. (2016). Technológiaalapú tesztelés az oktatásban: a problémamegoldó képesség fejlődésének értékelése. Akadémiai doktori értekezés. Retrieved from http://reald.mtak.hu/920/7/dc_968_14_doktori_mu.pdf

Morais, J. (1991). Phonological awareness: A bridge between language and literacy. In D. Sawyer, \& B. Fox (Eds.): Phonological awareness and reading acquisition (pp 31-71). New York: Springer-Verlag.

Muñoz, K., Valenzuela, M. F., \& Orellana, P. (2018). Phonological awareness instruction: A program training design for low-income children. International Journal of Educational Research, 89, 47-58.

Muter, V., Hulme, C., \& Snowling, M. (1997). Phonological Abilities Test. London: Psychological Corporation.

Nagy, J. (1980). 5-6 éves gyermekeink iskolakészültsége. Budapest: Akadémiai Kiadó. 
Nagy, J., Józsa, K., Vidákovich, T., \& Fazekasné Fenyvesi, M. (2004). DIFER Programcsomag: Diagnosztikus fejlődésvizsgáló és kritériumorientált fejlesztő rendszer 4-8 évesek számára. Szeged: Mozaik Kiadó.

Nation, K. \& Snowling, M. J. (2004). Beyond phonological skills: broader language skills contribute to the development of reading. Journal of Research in Reading, 27(4), 342356.

Newcomer, P.L., \& Hammill, D. D. (1997). Test of Language Development - Primary: Third Edition, Austin, TX: PRO-ED.

Nicolson, R. I., \& Facett, A. J. (1996). Dyslexia Early Screening Test. London: Psychological Corporation.

Ollé, J. (2013). Pedagógiai kultúra az információs társadalomban. In J. Ollé, A. Papp-Danka, D. Lévai, Sz. Tóth-Mózer, \& A. Virányi (Eds.), Oktatásinformatikai módszerek: Tanítás és tanulás az információs társadalomban (pp. 9-30). Budapest: ELTE Eötvös Kiadó.

Oulette, G. P., \& Haley, A. (2013). One complicated extended family: the influence of alphabetic knowledge and vocabulary on phonemic awareness. Journal of Research in Reading, 36(1), 29-41.

Palmer, S. B., Fleming, K. K., Horn, E. M., Butera,G. D., \& Lieber, J. A. (2018). Progress Monitoring in Inclusive Preschools: Using Children's School Success + Curriculum Framework. Inclusion, 6(2), 110-126.

Papp, I. (1966). Leíró magyar hangtan. Budapest, Tankönyvkiadó.

Pásztor, A. (2016). Az induktív gondolkodás technológia alapú mérése és fejlesztése. (Doctoral dissertation). $\quad$ Retrieved from http://doktori.bibl.uszeged.hu/3191/1/PasztorA_2016_disszertacio.pdf

Pennington, B. F. \& Lefly, D. L. (2001). Early reading development in children at family risk of dyslexia. Child Development, (72), 816-833.

Phillips, D., Gormley, W., \& Sara Anderson, S. (2016). The Effects of Tulsa's CAP Head Start Program on Middle-School Academic Outcomes and Progress. Developmental Psychology, 52(8), 1247-1261. 
Price-Mohr, R. \& Price, C. (2017). Gender differences in early reading strategies: A comparison of synthetic phonics only with a mixed approach to teaching reading to 4-5 year-old children. Early Childhood Education, 45, 613-620.

Pullen, P. C. \& Justice, L. M. (2003). Enhancing phonological awareness, print awareness, and oral language skills in preschool children. Intervention in School and Clinic, 39(2), $87-98$.

Rack, J. P., Snowling, M. J., \& Olson, R. K. (1992). The nonword reading deficit in developmental dyslexia: A review. Reading Research Quarterly. 27(1), 28-53.

Racsmány, M., Lukács, Á., Németh, D., \& Pléh, Cs. (2005). A verbális munkamemória magyar nyelvü vizsgálóeljárásai. Magyar Pszichológiai Szemle, 60(4), 479-505.

Ranschburg, P. (1939). Az emberi tévedések törvényszerüségei. Budapest, Novák Rudolf és Társa.

Rathvon, N. (2004). Early Reading Assessment: A Practitioner's Handbook. Guilford Press.

Rausch, A. \& Pásztor, A. (2017, July). Exploring the possibilities of online assessment of early numeracy in kindergarten. 41st Conference of the International Group for the Psychology of Mathematics Education (PME41), Singapore. Abstract retrieved from https://www.researchgate.net/publication/318317010_EXPLORING_THE_POSSIBILI TIES_OF_ONLINE_ASSESSMENT_OF_EARLY_NUMERACY_IN_KINDERGART EN

Rego, L. B. \& Bryant, P. E. (1993), The connection between phonological, syntactic and semantic skills and children's reading and spelling. European Journal of Psychology and Education. 8, 235-246.

Robertson, C. \& Salter, W. (1997). Phonological Awareness Test. East Moline, IL: LinguiSystems.

Robertson, C. \& Salter, W. (2007a). Phonological Awareness Test- $2^{\text {nd }}$ edition. East Moline, IL: LinguiSystems.

Robertson, C. \& Salter, W. (2007b). Examiner's manual. Phonological awareness test 2. East Moline, IL: Linguisystems. 
Rozin, P., \& Gleitman, L. R. (1977). The structure and acquisition of reading. II. The reading process and the acquisition of the alphabetic principle. In A. S. Reber \& D. Scarborough (Eds.), Toward a Psychology of Reading (pp. 55-141). Potomac, Maryland: Erlbaum.

Ruan, Y., Georgiou, G. K., Song, S., Li, Y., \& Shu, H. (2018). Does writing system influence the associations between phonological awareness, morphological awareness, and reading? A meta-analysis..Journal of Educational Psychology, 110(2), 180-202.

Rudginsky, L. T. \& Haskell, E. C. (2002). How to teach spelling. Toronto: Educators Publishing Service.

Schatschneider, C., Francis, D. J., Foorman, B. R., Fletcher, J. M., \& Mehta, P. (1999). The dimensionality of phonological awareness: An application of item response theory. Journal of Educational Psychology, 91(3), 439-449.

Siptár, P. (2006). Hangtan. In F. Kiefer (Ed.), Magyar nyelv (pp. 28-53). Budapest, Akadémiai Kiadó

Skibbe, L. E., Grimm, K. J., Bowles, R. P., \& Morisson, F. J. (2012). Literacy growth in the academic year versus summer from preschool through second grade: differential effects of schooling across four skills. Scientific Studies of Reading, 16(2), 141-165.

Smith, S. L. Scott, K. A., Roberts, J., \& Locke, J. (2008). Disabled readers' performance on tasks of phonological processing, rapid naming, and letter knowledge before and after kindergarten. Learning Disabilities Research \& Practice, 23, 113-124.

Snowling M.J., Gallagher A., \& Frith U. (2003). Family risk of dyslexia is continuous: individual differences in the precursors of reading skill. Child Development, 74(2), $358-73$.

Snowling, M. \& Hulme, C. (1989). A longitudinal case study of developmental phonological dyslexia. Cognitive Neuropsychology, 6, 379-401.

Stackhouse, J., Wells, B., Pascoe, M., \& Rees, R. (2002). Von der phonologischen Therapie zur phonologischen Bewusstheit. Sprache - Stimme - Gehör, 157-165.

Stahl, S. A., \& Murray, B. A. (1994). Defining Phonological Awareness and Its Relationship to Early Reading. Journal of Educational Psychology, 86, 221-234. 
Stanley, C. T., Petsher, Y., \& Catts, H. (2018). A longitudinal investigation of direc and indirect links between reading skills in kindergarten and reading comprehension in tnth grade. Reading \& Writing, 31(1), 133-153.

Stanovich, K. E. \& Siegel, L. (1994). Phenotypic performance profile of children with reading disabilities: A regression-based test of the phonological-core variable-difference model. Journal of Educational Psychology, 86, 24-53.

Storch, S. A., \& Whitehurst, G. J. (2002). Oral language and code-related precursors to reading: Evidence from a longitudinal structural model. Developmental Psychology, 38, 934-947.

Swanson, H. L. \& Siegel, L.(2001). Learning disabilities as a working memory deficit. Issues in Education: Contribution of Educational Psychology, 7, 1-48.

Szili, K. \& Pásztor, A. (2013, April). A beszédpercepció online mérése 1-3. osztályos tanulók körében. Paper presented at the Pedagógiai Értékelési Konferencia, Szeged. Abstract retrieved from http://www.edu.u-szeged.hu/pek2013/download/PEK2013_kotet.pdf

Szili, K. (2016a). A fonológiai tudatosság és a mentális lexikon fejlettségének számítógépalapú mérését lehetővé tevő tesztrendszer kidolgozása. Iskolakultúra, 26(2), 31-49.

Szili, K. (2016b). A fonológiai tudatosság és a mentális lexikon fejlettségének mérését lehetővé tevő online tesztrendszer kidolgozása és müködésének hatékonyságvizsgálata, Doktori Értekezés, Szegedi Tudományegyetem Doktori Iskola.

Szili, K. (2016c). A fonológiai tudatosság és a mentális lexikon fejlettségének online vizsgálata kisiskolások körében. Magyar Pedagógia, 116(3), 257-282.

Tarnóczy, T. (1995). A beszédérthetőség mint pszichofizikai fogalom. Fizikai Szemle, 3, 90102.

Tibi, S. \& Kirby, J.R. (2018). Investigating Phonological Awareness and Naming Speed as Predictors of Reading in Arabic, Scientific Studies of Reading, 22(1), 70-84.

Torgesen, J. K. \& Mathes, P. G. (2000). A Basic Guide to Understanding, Assessing and Teaching Phonological Awareness. Florida: Florida State University.

Torgesen, J. K., \& Bryant, B. R. (1994). Test of Phonological Awareness. Austin, TX: PROED.

Tóth, D. (2012). Mit, miért, hogyan? Mérés és értelmezés a kognitív olvasásfejlödési vizsgálatokban. Doktori értekezés, ELTE PPK 
Tóth, D. (2012). Mit, miért, hogyan? Mérés és értelmezés a kognitív olvasásfejlődési vizsgálatokban. Doktori értekezés. Eötvös Loránd Tudományegyetem Pszichológiai Doktori Iskola

Tóth, D., Csépe, V., Anniek, V., \& Blomert L. (2014). 3DM-H: a diszlexia differenciáldiagnózisa. Az olvasás és a helyesírás kognitív elemzése. Nyiregyháza, Kogentum.

Tunmer, W. E. \& Fletcher, C. M. (1981). The relationship between conceptual tempo, phonological awareness, and word recognition in beginning readers. Journal of Literacy Research, 13(2), 173-185.

van Tilborg, A., Segers, E., van Balkom, H., \& Verhoeven, L. (2018). Modeling individual variation in early literacy skills in kindergarten children with intellectual disabilities. Research in Developmental Disabilities, 72, 1-12.

Wackerle-Hollman, A., Schmitt, B., Bradfield, T., Rodriguez, M., \& McConnell, S. (2013). Redefining individual growth and development indicators: Phonological awareness. Journal of Learning Disabilities, 48(5), 495-510. doi: 10.1177/0022219413510181

Wagner, R. K., Torgesen, J. K., \& Rashotte, C. A. (1994). Development of reading-related phonological processing abilities: New evidence of bidirectional causality from a latent variable longitudinal study. Developmental Psychology, 30(1), 73-87. http://dx.doi.org/10.1037/0012-1649.30.1.73

Wagner, R. K., Torgesen, J.K., Rashotte, C.A., \& Pearson, N.A. (2013). Comprehensive Test of Phonological Processing, Second Edition (CTOPP-2). Austin, TX: PRO_ED.

Wagner, R.K., Torgesen, J.K., \& Rashotte, C. A. (1999). Comprehensive Test of Phonological Processing. Austin, TX: PRO_ED.

Williams, K.T. (2002). Group Reading Assessment and Diagnostic Evaluation. Circle Press, MN:American Guide Service.

Wolf, M. \& Bowers P. G. (1999). The double-deficit hypothesis for the developmental dyslexias. Journal of Educational Psychology, 91, 415-438.

Yopp, H. K. (1988). The Validity and Reliability of Phonemic Awareness Tests. Reading Research Quarterly, 23, 159-177. 
Yopp, H. K. (1992). Developing phonemic awareness in Young Children. The Reading Teacher, 45(9), 696-703.

Yopp, H. K. (1995). A test for assessing phonemic awareness in young children. The Reading Teacher, 49, 20-29.

Zaranis, N., \& Oikonomidis, V. (2015). Profiling the attitudes of Greek kindergarten teachers towards computers. Educational and Information Technologies, 20, 201-215. doi: 10.1007/s10639-013-9296-2

Ziegler, J. C., Goswami, U. (2005). Reading acquistion, developmental dyslexia, and skilled reading arcoss languages: a psycholinguistic grain size theory. Psychological Bulletin, 131(1), 3-29.

Zifcak, M. (1981). Phonological awareness and reading acquisition. Contemporary Educational Psychology, 6(2), 117-126.

Zsigri, Gy. (2006). Magyar mássalhangzószabályok. Szeged, Jate Press. 


\section{ÁBRAJEGYZÉK}

10. ábra A fonológiai tudatosság online tesztelésének első megjelenési formája

Hiba! A

könyvjelző nem létezik.

11. ábra Változatok a fonémaazonosítás feladat megjelenítési formájára .. Hiba! A könyvjelző nem létezik.

12. ábra A fonémaazonosítás a hívóhang helyének meghatározásával típusú feladat megjelenítési formája

Hiba! A könyvjelzö nem létezik.

13. ábra A szókezdő hang azonosítását kérő feladat megjelenítési formájaHiba! A könyvjelző nem létezik.

14. ábra A szótag- és a fonémaszintézist, valamint a szótag- és a fonématörlést kérő feladatok megjelenítési formája

.Hiba! A könyvjelző nem létezik.

15. ábra A szótag- és a fonémaszegmentálás feladatok megjelenítési formája

Hiba! A könyvjelző nem létezik.

16. ábra A fonémaszegmentálás feladat eredeti és módosított változatának megjelenítési formája

Hiba! A könyvjelző nem létezik.

17. ábra A rögzített tesztek egységes nyitóoldala .... 50

18. ábra A rögzített tesztek egységes záróoldala. 50

19. ábra A tesztben való előrehaladást segítő instrukciót tartalmazó dia. 51

20. ábra A tesztben való eligazodást segítő instrukciót tartalmazó dia 51

21. ábra Az adatfelvétel évében (2015) 1. évfolyamot megkezdő tanulók, valamint a vizsgálatainkba bevont minta regionális eloszlása....

22. ábra Az adatfelvétel évében (2015) 1. évfolyamot megkezdő lány tanulók, valamint a vizsgálatainkba bevont lány tanulók regionális eloszlása

23. ábra Az adatfelvétel évében (2015) 1. évfolyamot megkezdő fiú tanulók, valamint a vizsgálatainkba bevont fiú tanulók regionális eloszlása.

24. ábra Az adatfelvétel évében (2015) 1. évfolyamot megkezdő tanulók megyénkénti eloszlása

25. ábra Az adatfelvétel évében (2015) 1. évfolyamot megkezdő lány tanulók, valamint a vizsgálatainkba bevont lány tanulók megyénkénti eloszlása

26. ábra Az adatfelvétel évében (2015) 1. évfolyamot megkezdő fiú tanulók, valamint a vizsgálatainkba bevont fiú tanulók megyénkénti eloszlása.

27. ábra Példafeladat a szótagszintézis feladat megjelenítési formájára

28. ábra Példafeladat a szótagszegmentálás feladat megjelenítési formájára

29. ábra Példafeladat a szótagtörlés feladat megjelenítési formájára 
30. ábra Példafeladat a fonémaazonosítás feladat megjelenítési formájára

31. ábra Példafeladat a fonémaazonosítás a hívóhang helyének meghatározásával típusú feladat megjelenítési formájára

32. ábra Példafeladat a szókezdő hangok azonosítását vizsgáló feladat megjelenítési formájára

33. ábra Példafeladat a fonémaszintézis feladat megjelenítési formájára

34. ábra Példafeladat a fonémaszegmentálás feladat megjelenítési formájára .66

35. ábra Példafeladat a fonématörlés feladat megjelenítési formájára. 66

36. ábra Egy kattintást kérő géphasználat példafeladat Hiba! A könyvjelző nem létezik.

37. ábra Több kattintást kérő géphasználat feladat Hiba! A könyvjelző nem létezik.

38. ábra Vonszolást, húzást kérő géphasználat feladat Hiba! A könyvjelző nem létezik.

39. ábra Az itemek elkülönítés mutatóinak eloszlási gyakorisága 69

40. ábra Az első osztályos fonológiai tudatosság teszt személy-item térképe .71

41. ábra Az első évfolyamos fonológiai tudatosság teszt hierarchikus faktorelemzése, 1. modell.

42. ábra Az első évfolyamos fonológiai tudatosság teszt hierarchikus faktorelemzése, 2. modell.

43. ábra Az első évfolyamos fonológiai tudatosság teszt hierarchikus faktorelemzése, 3. modell.....

44. ábra Az adatfelvétel évében (2016) 1. évfolyamot megkezdő tanulók, valamint a vizsgálatainkba bevont minta regionális eloszlása....

45. ábra Az adatfelvétel évében (2016) 1. évfolyamot megkezdő lány tanulók, valamint a vizsgálatainkba bevont lány tanulók regionális eloszlása ...

46. ábra Az adatfelvétel évében (2016) 1. évfolyamot megkezdő fiú tanulók, valamint a vizsgálatainkba bevont fiú tanulók regionális eloszlása.

47. ábra Az adatfelvétel évében (2016) 1. évfolyamot megkezdő tanulók, valamint a vizsgálatainkba bevont minta megyénkénti eloszlása

48. ábra Az adatfelvétel évében (2016) 1. évfolyamot megkezdő lány tanulók, valamint a vizsgálatainkba bevont lány tanulók megyénkénti eloszlása

49. ábra Az adatfelvétel évében (2016) 1. évfolyamot megkezdő fiú tanulók, valamint a vizsgálatainkba bevont fiú tanulók megyénkénti eloszlása.

50. ábra - Példafeladat a fonémaszegmentálás feladat megjelenítési formájára

51. ábra - Példafeladat a módosított fonémaszegmentálás feladat megjelenítési formájára ....93

52. ábra Az itemek elkülönítés mutatóinak eloszlási gyakorisága az első osztályos

fonématudatossági teszt esetében 
53. ábra Az első osztályos fonématudatosság teszt személy-item térképe. .98

54. ábra Célmezőbe való kattintás gyakorlása

55. ábra Adott célmezőbe történő válasz törlése/javítása..

56. ábra Példafeladat a függőleges vonszolás gyakorlására

57. ábra Példafeladat a balról jobbra történő vonszolásra

58. ábra Az itemek elkülönítés mutatóinak eloszlási gyakorisága

59. ábra Az óvodai korosztály esetében rögzítet fonológiai tudatosság teszt személy-item térképe

60. ábra A fonológiai tudatosság teszt hierarchikus faktorelemzése az óvodai korcsoport körében, 1. modell

61. ábra A fonológiai tudatosság teszt hierarchikus faktorelemzése az óvodai korcsoport körében, 2. modell.

62. ábra A fonológiai tudatosság teszt hierarchikus faktorelemzése az óvodai korcsoport körében, 3. modell.

63. ábra Az óvodai korosztály és az általános iskola első osztályos tanulók körében rögzített fonológiai tudatosság teszt közös itemjeinek személy-item térképe 


\section{TÁBLÁZATOK JEGYZÉKE}

1. táblázat. Az angol és magyar nyelv összehasonlítása a fonológiai tudatosság szemszögéből

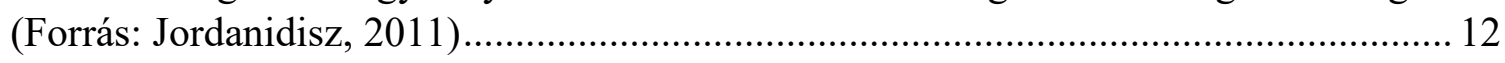

2. táblázat. A fonológiai tudatosság fejlődése óvodáskorban (Forrás: Farrall, 2012)............. 13

3. táblázat. A fonológiai tudatosság mérőfeladatainak nehézségi szintjét befolyásoló tényezők

4. táblázat. A fonématudatosság mérőfeladatainak nehézségi szintjét befolyásoló tényezők . 17

5. táblázat. Betütévesztések lehetősége optikai, akusztikai és ejtésbeli hasonlóság alapján

(Forrás: Meixner \& Justhné, (1967. p. 32-3.).............................................................. 19

6. táblázat. A korai olvasási képesség komponenseire irányuló mérések .............................. 26

7. táblázat. Az olvasás komponenseire alapuló mérőeszközök ............................................. 30

8. táblázat. A fonológiai tudatosság magyar nyelvű mérőeljárásai ....................................... 33

9. táblázat. Az élőszavas tesztfelvétel és az online tesztelés jellemzői .................................. 36

10. táblázat. Az asztali gépes (PC-s) és tabeletes tesztelés közti különbségek ....................... 42

11. táblázat. A dolgozatban szereplő mérőeszközök megnevezése és felvételének ütemezése46

12. táblázat. A minták összetétele, nemek szerinti bontása............................................... 49

13. táblázat. Az online fonológiai tudatosság teszt felépítése ..............................................62

14. táblázat. A fonológiai tudatosság teljes tesztjének és résztesztjeinek reliabilitás mutatói

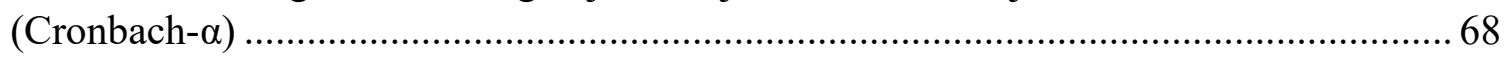

15. táblázat. Az elkülönítés mutatók figyelembe vételével módosított teszt felépítése, a teljes teszt és a résztesztek reliabilitás mutatói (Cronbach- $\alpha$ ) …............................................... 69

16. táblázat. A nyelvi egységek és a teljes teszt közti korrelációs együtthatók .............. Hiba! A könyvjelző nem létezik.

17. táblázat. A műveleti szintek és a teljes teszt közti korrelációs együtthatók.............. Hiba! A könyvjelző nem létezik.

18. táblázat. A feladattípusok és a teljes teszt közti korrelációs együtthatók .73

19. táblázat. Az első osztályos fonológiai tudatosság teszt megerősítő faktorelemzésének

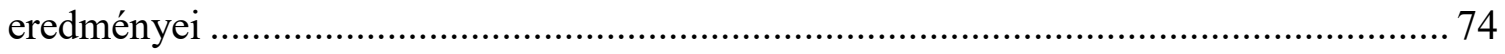

20. táblázat. Az első osztályos fonológiai tudatosság teszt belső kontsruktumának meghatározása

21. táblázat. A tanulók teszten elért teljesítményének átlaga és szórása................................ 78

22. táblázat. A teljes teszt és a feladattípusok eloszlásainak statisztikai mutatói .................... 79 
23. táblázat. A nem és résztesztek közti korrelációs együtthatók értékei, a vonatkozó szignifikancia értékek és a mintaelemszáma.

24. táblázat. A fonológiai tudatosság fejlettsége az általános iskola első osztályos tanulók körében.....

25. táblázat. A tanulók átlagéletkora a teszt felvételének idejében.

26. táblázat. A tanulók teljesítményének átlaga és szórása a születési év függvényében

27. táblázat. A tanulók teljesítményének átlaga és szórása a születési félév függvényében.... 83

28. táblázat. A géphasználat teszt és a fonológia tudatosság teszt összefüggésének vizsgálata az általános iskola első osztályos tanulóinak körében.

29. táblázat. A fonématudatosság teszt felépítése.

30. táblázat. A fonématudatosság teljes tesztjének és résztesztjeinek reliabilitás mutatói (Cronbach- $\alpha)$

31. táblázat. Az elkülönítés mutatók figyelembe vételével módosított teszt felépítése, a teljes teszt és a résztesztek reliabilitás mutatói (Cronbach- $\alpha)$

32. táblázat. A feladattípusok egymásközti, valamint a feladattípusok és teljes teszt közti korrelációs együtthatók

33. táblázat. A tanulók teszten nyújtott teljesítményének átlaga és szórása 100

34. táblázat. A teljes és a résztesztek eloszlásainak statisztikai mutatói 100

35. táblázat. A nem és résztesztek közti korrelációs együtthatók értékei, a vonatkozó szignifikancia értékek és a mintaelemszáma.

36. táblázat. A fonématudatosság fejlettsége az általános iskola első osztályosainak körében

37. táblázat. A tanulók átlagéletkora a teszt felvételének idejében. 102

38. táblázat. A tanulók teljesítményének átlaga és szórása a születési év függvényében 103

39. táblázat. A tanulók teljesítményének átlaga és szórása a születési félév függvényében.. 104

40. táblázat. A géphasználat teszt és a fonématudatosság teszt összefüggésének vizsgálata az óvodás korosztály körében

41. táblázat. A fonológiai tudatosság teljes tesztjének és résztesztjeinek reliabilitás mutatói (Cronbach- $\alpha$ )

42. táblázat. Az elkülönítés mutatók figyelembe vételével módosított teszt felépítése, a teljes teszt és a résztesztek reliabilitás mutatói (Cronbach- $\alpha)$

43. táblázat. A nyelvi egységek és a teljes teszt közti korrelációs együtthatók

44. táblázat. A müveleti szintek és a teljes teszt közti korrelációs együtthatók

45. táblázat. A résztesztek és a teljes teszt közti korrelációs együtthatók. 
46. táblázat. Az óvodai fonológiai tudatosság teszt megerősítő faktorelemzésének eredményei

47. táblázat. Az óvodai fonológiai tudatosság teszt belső kontsruktumának meghatározása 119

48. táblázat. A gyermekek teszten nyújtott teljesítményének átlaga és szórása.

49. táblázat. A teljes és a résztesztek eloszlásainak statisztikai mutatói

50. táblázat. A gyermekek átlagéletkora és annak szórása a teszt rögzítésének időpontjában

51. táblázat. A gyermekek teljesítményének átlaga és szórása a születési év függvényében 125

52. táblázat. A gyermekek teljesítményének átlaga és szórása a születési félév függvényében

53. táblázat. A nem és résztesztek közti korrelációs együtthatók értékei, a vonatkozó szignifikancia értékek és a mintaelemszáma......................................................... 126

54. táblázat. A fonológiai tudatosság fejlettsége óvodáskorban

55. táblázat. A géphasználat teszt és a fonológia tudatosság teszt összefüggésének vizsgálata

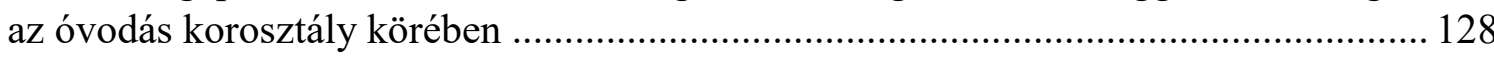

56. táblázat. Az óvodai és általános iskolai tesztfelvétel során rögzített közös itemek

57. táblázat. A fonológiai tudatosság fejlettsége az óvoda befejező és az iskola kezdő szakaszában

58. táblázat. A vizsgált minta átlagéletkora a teszt felvételének idejében

59. táblázat. Az óvodás gyermekek és az iskolás tanulók teszten nyújtott átlagteljesítménye és annak szórása a születési év, a feladattípusok, a müveletek és az összteszt szempontjából 


\section{MELLÉKLETEK JEGYZÉKE}

1. számú melléklet. A fonológiai tudatosság szemtől-szembeni mérőeljárásai 173

2. számú melléklet. Tájékoztató az online iskolakészültség mérőeszköz-csomagról, 2015 őszi adatfelvétel

3. számú melléklet. A tesztben megjelenő feladattípusok gyakorlására vonatkozó géphasználat feladatok

4. számú melléklet: Az első osztályos tanulók körében, 2015-ben rögzített fonológiai tudatosság teszt statisztikai mutatói

5. számú melléklet: Az első osztályos fonológiai tudatosság teszt megerősítő faktorelemzésének eredményei

6. számú melléklet: Az online iskolakezdő mérőeszközcsomag mérési útmutatója, 2016 őszi adatfelvétel

7. számú melléklet: Az első osztályos tanulók körében, 2016-ban rögzített fonématudatosság teszt elkülönítés mutatói

8. számú melléklet: Informált beleegyező nyilatkozat az óvodai mérésekhez 190

9. számú melléklet: Az óvodás gyermekek körében rögzített fonológiai tudatosság teszt statisztikai mutatói.

10. számú melléklet: Az óvodai mintán rögzített fonológiai tudatosság teszt megerősítő faktorelemzésének eredményei 
1. számú melléklet. A fonológiai tudatosság szemtöl-szembeni méröeljárásai

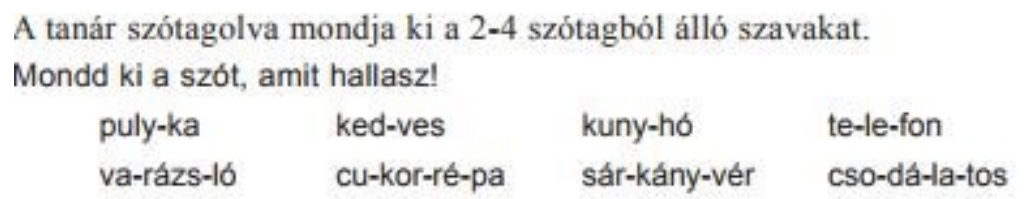

A szótagszintézis feladatok szemtöl szembeni felvételen alapuló példafeladata

(Forrás: Józsa, Steklács, Hódi, Csíkos, Adamikné, Molnár, Nagy, \& Szenczi, 2012. p. 225)

\begin{tabular}{clll}
\multicolumn{2}{c}{ Hányat tapsolsz a szóra? } & & \\
óvoda & barlang & szőlő & kabát \\
sport & koszorú & strand & csokoládé
\end{tabular}

A szótagszegmentálás feladatok szemtöl szembeni felvételen alapuló példafeladata

(Forrás: Józsa et al. 2012. p. 224)

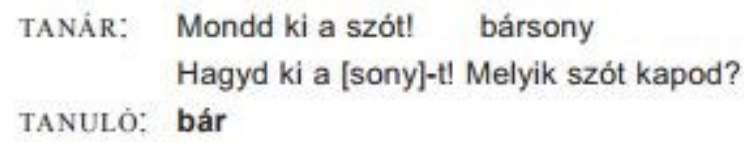

A szótagtörlés feladatok szemtöl szembeni felvételen alapuló példafeladata, a törlendö szótag megnevezésével

(Forrás: Józsa et al. 2012. p. 225)

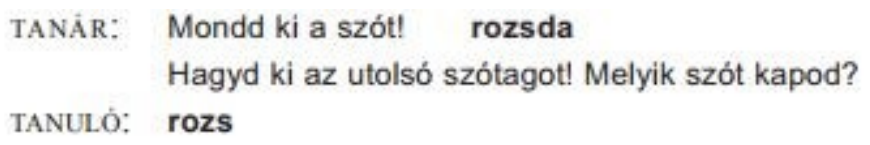

A szótagtörlés feladatok szemtöl szembeni felvételen alapuló példafeladata, a törlendő szótag szóbeli pozíciójának megnevezésével

(Forás: Józsa et al. 2012.p. 225) 
TANÁR: Most írjuk fel a sál szó hangjait a táblára!

[s] leirva s [á] leirva á [l] leírva I

TANÁR: (Felirja a sál szót a táblára.)

Most olvassuk fel a táblára irt szót! sál

A fonémaszintézis feladatok szemtöl szembeni felvételen alapuló példafeladata

(Forrás: Józsa et al. 2012.p. 228)

TANÁR: Hány hangot hallasz a következő szóban?

sál

TANULó: [s] [â] [l]. Három hangot hallok.

A fonémaszegmentálás feladatok szemtöl szembeni felvételen alapuló példafeladata

(Forrás: Józsa et al. 2012. p. 227)

Bontsd hangokra a következö szavakat!

Hány hangot hallasz?

Rakj ki annyi gombot, ahány hangot hallasz a szóban!

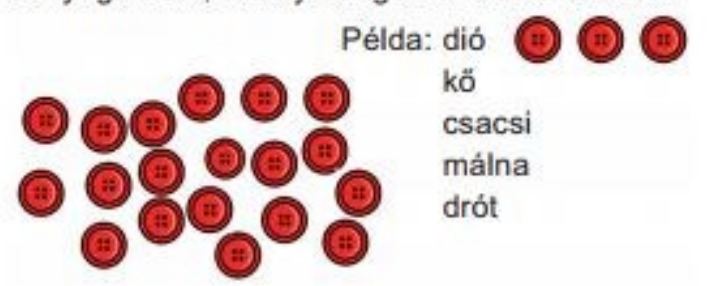

A fonémaszegmentálás feladatok szemtől szembeni felvételen alapuló példafeladata manuális segédeszközzel

(Forrás: Józsa et al. 2012. p. 230)

TANÁR: Mondd ki a kapa szót az első hang nélkül!

További lehetséges példák: hír, fárad, süveg

TANULó: A kapa a [k] nélkül apa.

A fonématörlés feladatok szemtöl szembeni felvételen alapuló példafeladata

(Forrás: Józsa et al. 2012. p. 228) 
Hol hallod a [c] hangot a következö szavakban?

cica cékla cumi

A fonémaazonositás (szókezdö hang azonositása) feladatok szemtöl szembeni felvételen alapuló példafeladata

(Forrás: Józsa et al. 2012.p. 228) 
2. számú melléklet: Tájékoztató az online iskolakészültség méröeszköz-csomagról, 2015 öszi adatfelvétel

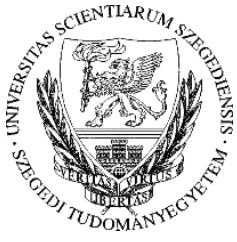

SZEGEDI TUDOMÁNYEGYETEM

OKTATÁSELMÉLETI KUTATÓCSOPORT

TÁMOP 3.1.9-11/1-2012-0001

SZÉCHENYI 2020

Kedves Kapcsolattartó!

Köszönjük, hogy az Ön iskolája is részt vesz a Szegedi Tudományegyetem Oktatáselméleti Kutatócsoportjának „Diagnosztikus mérések fejlesztése” című felmérés-sorozatában. Kutatássorozatunk következő állomásaként egy 1. osztályos tanulók számára összeállított, új generációs iskolakészültség mérőeszköz-csomagot kínálunk Önöknek. Ennek keretében lehetőségük adódik, hogy az 1. évfolyamos tanulóikkal tét nélkül kipróbálják és teszteljék a feladatokat, s egyszersmind képet kaphatnak a tanulók iskolakészültségi szintjéről is.

Az új generációs iskolakészültség mérőeszköz-csomag két online tesztblokkból áll, mely összesen 2 tanórát vesz igénybe.

1. játékos géphasználat és olvasási előképességek teszt (1 tanóra)

2. feladattartás és matematika teszt (1 tanóra).

Ezen kívül lehetőségük van egy szabadon választható tesztblokk kitöltésére is, mely szintén 1 tanórát igényel:

3. induktív gondolkodás és zenei képességek teszt (1 tanóra).

A tesztekröl bővebb információt az iskolakészültség leírás címü csatolt dokumentumban találhat.

A játékos géphasználati mérés feladatainak jellegéröl demo tesztünk kipróbálásával tájékozódhat, melyet az alábbi linken érhet el:

edia.hu/gephaszn

Az online adatfelvételhez szükséges feltételek a következők:

- internetkapcsolattal rendelkező számítógépek 
- Mozilla Firefox vagy Google Chrome böngésző (mindkettő a legfrissebb verzióval)

- fülhallgatók

Kérjük, hogy a regisztrációs ürlap kitöltésével legkésőbb 2015. október 22-éig jelezze, hogy mely osztállyal/osztályokkal kíván részt venni a mérésben, s hogy a két kötelező blokkon kívül részt kívánnak-e venni az induktív gondolkodás és zenei képességek teszten is!

\section{A regisztrációs ürlap linkje:}

http://www.edu.u-szeged.hu/urlap/uj-gen-iskolafelkeszultsegi-meres-1evf 
DIAGNOSZTIKUS MÉRÉSEK FEJLESZTÉSE

Kérjük, a mérésben résztvevő osztályok mérési azonosítós táblázatait a csatolt segédlet alapján töltse fel az eDia felületre (pontos születési dátumokat és generált mérési azonosítókat tartalmazó, .xls kiterjesztésű Excel fileban)! Felhívjuk a figyelmét, hogy amíg az eDia felületén nincsenek fent az adott osztály(ok) adatai a kért módon, addig nem tudjuk küldeni a mérési útmutatót, és a mérést nem tudják elkezdeni, hiszen a teszt eléréséhez az egyedi mérési azonosítók elengedhetetlenek!

\section{A mérés lebonyolítására 2015 októberében-novemberében lesz lehetőségük.}

A vizsgálat ideje alatt informatikus kollégáink és a kutatásszervező csoport munkatársai rendelkezésükre állnak az iskola@edu.u-szeged.hu e-mail címen, vagy a következő telefonszámok egyikén: 06-62-544-628, 06-62-343-063, 06-62-343-487.

Köszönjük, hogy együttmüködésükkel támogatják munkánkat!

Szeged, 2015. október 15.

Üdvözlettel:

SZTE-OK Kutatásszervező Munkacsoport 
3. számú melléklet. A tesztben megjelenö feladattípusok gyakorlására vonatkozó géphasználat feladatok (Pásztor, 2016 alapján)

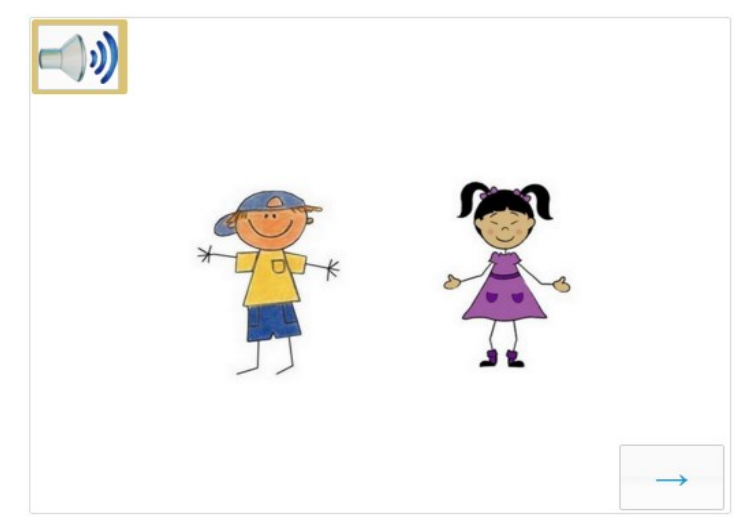

Egy kattintást kérő géphasználat példafeladat Instrukció: Fiú vagy lány vagy? Kattints rá a megfelelö képre, majd a nyilra!

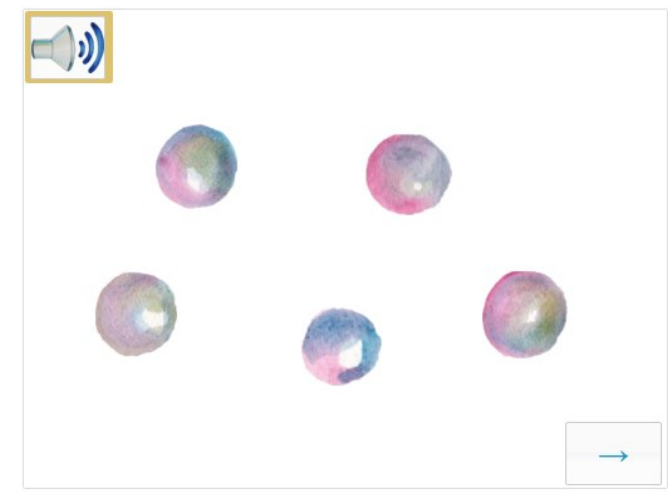

Több kattintást kérő géphasználat feladat Instrukció: Pukkaszd ki az összes buborékot! Kattints rájuk!

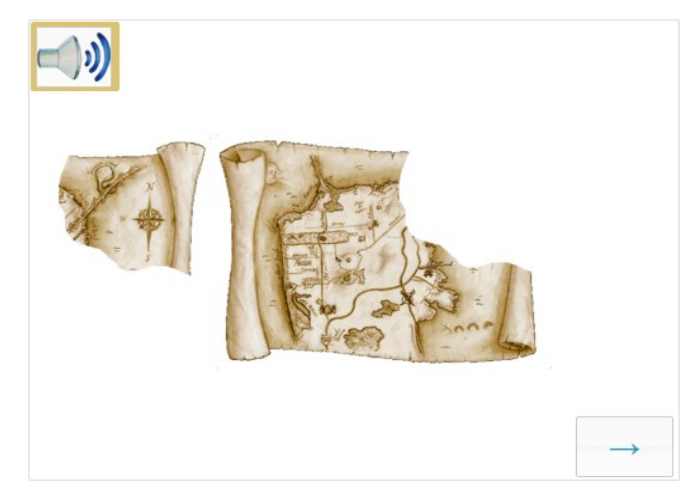

Vonszolást, húzást kérő géphasználat feladat Instrukció: Szétszakadt a kincses térkép. Húzd a térképhez a leszakadt darabot! Kattints rá a térkép leszakadt darabjára, tartsd az ujjad a gombon, és húzd a helyére!

A tesztet megelőzte a géphasználat teszt, melynek kitöltésével a tanulók gyakorolhatták a kézegér együttmozgásának törvényszerüségét, illetve játékos feladatokon keresztül megismerkedhettek a tesztre jellemző itemtípusokkal, gyakorolhatták az egy (36. ábra) vagy több helyre, képre való kattintást (37. ábra), illetve az itemek húzását, vonszolását (38. ábra). A példafeladatok Pásztor (2016) alapján kerültek beemelésre. 
4. számú melléklet: Az elsö osztályos tanulók körében, 2015-ben rögzített fonológiai tudatosság teszt statisztikai mutatói

Megjegyzések a feladatok elnevezéséhez: Sz_Szin: szótagszintézis; Sz_Szeg: szótagszegmentálás; Sz_Tor: szótagtörlés; F_Szh: szókezdő hang azonosítása; F_Szeg: fonémaszegmentálás; F_Tor: fonématörlés; F_szin: fonémaszintézis; F_Az: fonémaazonosítás; F_Hh: fonémaazonosítás a hívóhang helyének meghatározásával

\begin{tabular}{|c|c|c|c|c|}
\hline Item & Átlag & Szórás & $\begin{array}{c}\text { Elkülönítés } \\
\text { mutató }\end{array}$ & $\begin{array}{l}\text { Cronbach- } \alpha \text { változása } \\
\text { az item törlése esetén }\end{array}$ \\
\hline F_01_Sz_Szin & 0,89 & 0,313 & 0,353 & 0,891 \\
\hline F_02_Sz_Szin & 0,90 & 0,303 & 0,348 & 0,891 \\
\hline F_03_Sz_Szin & 0,77 & 0,418 & 0,386 & 0,891 \\
\hline F_04_Sz_Szin & 0,88 & 0,326 & 0,419 & 0,891 \\
\hline F_05_Sz_Szin & 0,92 & 0,278 & 0,328 & 0,891 \\
\hline F_06_Sz_Szeg & 0,32 & 0,468 & 0,338 & 0,891 \\
\hline F_07_Sz_Szeg & 0,42 & 0,493 & 0,354 & 0,891 \\
\hline F_08_Sz_Szeg & 0,43 & 0,495 & 0,413 & 0,890 \\
\hline F_09_Sz_Szeg & 0,38 & 0,486 & 0,376 & 0,891 \\
\hline F_10_Sz_Szeg & 0,45 & 0,497 & 0,367 & 0,891 \\
\hline F_11_Sz_Tor & 0,72 & 0,451 & 0,234 & 0,893 \\
\hline F_12_Sz_Tor & 0,34 & 0,474 & 0,204 & 0,893 \\
\hline F_13_Sz_Tor & 0,35 & 0,478 & 0,151 & 0,894 \\
\hline F_14_Sz_Tor & 0,82 & 0,384 & 0,360 & 0,891 \\
\hline F_15_Sz_Tor & 0,64 & 0,479 & 0,352 & 0,891 \\
\hline F_16_F_Az & 0,74 & 0,438 & 0,115 & 0,894 \\
\hline F_17_F_Az & 0,72 & 0,449 & 0,359 & 0,891 \\
\hline F_18_F_Az & 0,47 & 0,499 & 0,345 & 0,891 \\
\hline F_19_F_Az & 0,65 & 0,479 & 0,262 & 0,892 \\
\hline F_20_F_Az & 0,52 & 0,500 & 0,477 & 0,889 \\
\hline F_21_F_Az & 0,43 & 0,495 & 0,315 & 0,892 \\
\hline F_22_F_Az & 0,52 & 0,500 & 0,423 & 0,890 \\
\hline F_23_F_Az & 0,51 & 0,500 & 0,425 & 0,890 \\
\hline F_24_F_Az & 0,22 & 0,412 & 0,050 & 0,894 \\
\hline F_25_F_Az & 0,58 & 0,494 & 0,330 & 0,891 \\
\hline F_26_F_Hh & 0,57 & 0,495 & 0,467 & 0,890 \\
\hline
\end{tabular}




\begin{tabular}{|c|c|c|c|c|}
\hline F_27_F_Hh & 0,53 & 0,499 & 0,376 & 0,891 \\
\hline F_28_F_Hh & 0,39 & 0,488 & 0,423 & 0,890 \\
\hline F_29_F_Hh & 0,42 & 0,494 & 0,445 & 0,890 \\
\hline F_30_F_Hh & 0,45 & 0,498 & 0,492 & 0,889 \\
\hline F_31_F_Hh & 0,45 & 0,498 & 0,448 & 0,890 \\
\hline F_32_F_Hh & 0,56 & 0,497 & 0,517 & 0,889 \\
\hline F_33_F_Hh & 0,57 & 0,496 & 0,545 & 0,888 \\
\hline F_34_F_Hh & 0,47 & 0,499 & 0,476 & 0,889 \\
\hline F_35_F_Hh & 0,45 & 0,498 & 0,473 & 0,890 \\
\hline F_36_F_Szeg & 0,41 & 0,491 & 0,381 & 0,891 \\
\hline F_37_F_Szeg & 0,24 & 0,427 & 0,385 & 0,891 \\
\hline F_38_F_Szeg & 0,38 & 0,486 & 0,393 & 0,891 \\
\hline F_39_F_Szeg & 0,21 & 0,411 & 0,394 & 0,891 \\
\hline F_40_F_Szeg & 0,08 & 0,268 & 0,281 & 0,892 \\
\hline F_41_F_Szh & 0,50 & 0,500 & 0,525 & 0,889 \\
\hline F_42_F_Szh & 0,45 & 0,498 & 0,464 & 0,890 \\
\hline F_43_F_Szh & 0,51 & 0,500 & 0,494 & 0,889 \\
\hline F_44_F_Szh & 0,47 & 0,499 & 0,458 & 0,890 \\
\hline F_45_F_Szh & 0,52 & 0,500 & 0,498 & 0,889 \\
\hline F_46_F_Szin & 0,77 & 0,421 & 0,393 & 0,891 \\
\hline F_47_F_Szin & 0,66 & 0,473 & 0,422 & 0,890 \\
\hline F_48_F_Szin & 0,79 & 0,406 & 0,442 & 0,890 \\
\hline F_49_F_Szin & 0,85 & 0,357 & 0,447 & 0,890 \\
\hline F_50_F_Szin & 0,84 & 0,363 & 0,414 & 0,890 \\
\hline F_51_F_Tor & 0,73 & 0,443 & 0,356 & 0,891 \\
\hline F_52_F_Tor & 0,79 & 0,410 & 0,434 & 0,890 \\
\hline F_53_F_Tor & 0,81 & 0,394 & 0,418 & 0,890 \\
\hline F_54_F_Tor & 0,80 & 0,402 & 0,434 & 0,890 \\
\hline F_55_F_Tor & 0,65 & 0,478 & 0,348 & 0,891 \\
\hline
\end{tabular}


5. számú melléklet: Az elsö osztályos fonológiai tudatosság teszt megerösitö faktorelemzésének eredményei

Megjegyzések a feladatok elnevezéséhez: Sz_Szin: szótagszintézis; Sz_Szeg: szótagszegmentálás; Sz_Tor: szótagtörlés; F_Szh: szókezdő hang azonosítása; F_Szeg: fonémaszegmentálás; F_Tor: fonématörlés; F_szin: fonémaszintézis; F_Az: fonémaazonosítás; F_Hh: fonémaazonosítás a hívóhang helyének meghatározásával

\begin{tabular}{|c|c|c|c|}
\hline & Estimate & S.E. & P-VALUE \\
\hline F_01_Sz_Szin & 0,063 & 0,003 & 0,000 \\
\hline F_02_Sz_Szin & 0,057 & 0,003 & 0,000 \\
\hline F_03_Sz_Szin & 0,140 & 0,006 & 0,000 \\
\hline F_04_Sz_Szin & 0,069 & 0,003 & 0,000 \\
\hline F_05_Sz_Szin & 0,053 & 0,003 & 0,000 \\
\hline F_01_Sz_Szeg & 0,143 & 0,007 & 0,000 \\
\hline F_02_Sz_Szeg & 0,130 & 0,007 & 0,000 \\
\hline F_03_Sz_Szeg & 0,136 & 0,007 & 0,000 \\
\hline F_04_Sz_Szeg & 0,131 & 0,007 & 0,000 \\
\hline F_05_Sz_Szeg & 0,141 & 0,007 & 0,000 \\
\hline F_01_Sz_Tor & 0,112 & 0,006 & 0,000 \\
\hline F_02_Sz_Tor & 0,180 & 0,009 & 0,000 \\
\hline F_01_F_Az & 0,191 & 0,008 & 0,000 \\
\hline F_02_F_Az & 0,189 & 0,008 & 0,000 \\
\hline F_03_F_Az & 0,131 & 0,007 & 0,000 \\
\hline F_04_F_Az & 0,198 & 0,008 & 0,000 \\
\hline F_05_F_Az & 0,146 & 0,007 & 0,000 \\
\hline F_06_F_Az & 0,151 & 0,007 & 0,000 \\
\hline F_07_F_Az & 0,240 & 0,01 & 0,000 \\
\hline F_01_F_Hh & 0,185 & 0,008 & 0,000 \\
\hline F_02_F_Hh & 0,215 & 0,009 & 0,000 \\
\hline F_03_F_Hh & 0,195 & 0,008 & 0,000 \\
\hline F_04_F_Hh & 0,188 & 0,008 & 0,000 \\
\hline F_05_F_Hh & 0,185 & 0,008 & 0,000 \\
\hline F_06_F_Hh & 0,185 & 0,008 & 0,000 \\
\hline F_07_F_Hh & 0,155 & 0,007 & 0,000 \\
\hline F_08_F_Hh & 0,146 & 0,007 & 0,000 \\
\hline
\end{tabular}




$\begin{array}{llll}\text { F_09_F_Hh } & 0,175 & 0,008 & 0,000 \\ \text { F_10_F_Hh } & 0,181 & 0,008 & 0,000 \\ \text { F_01_F_Szeg } & 0,167 & 0,007 & 0,000 \\ \text { F_02_F_Szeg } & 0,079 & 0,005 & 0,000 \\ \text { F_03_F_Szeg } & 0,137 & 0,007 & 0,000 \\ \text { F_04_F_Szeg } & 0,077 & 0,004 & 0,000 \\ \text { F_01_F_Szh } & 0,152 & 0,007 & 0,000 \\ \text { F_02_F_Szh } & 0,167 & 0,008 & 0,000 \\ \text { F_03_F_Szh } & 0,150 & 0,007 & 0,000 \\ \text { F_04_F_Szh } & 0,171 & 0,008 & 0,000 \\ \text { F_05_F_Szh } & 0,151 & 0,007 & 0,000 \\ \text { F_01_F_Szin } & 0,130 & 0,006 & 0,000 \\ \text { F_02_F_Szin } & 0,163 & 0,007 & 0,000 \\ \text { F_03_F_Szin } & 0,097 & 0,005 & 0,000 \\ \text { F_04_F_Szin } & 0,076 & 0,004 & 0,000 \\ \text { F_05_F_Szin } & 0,077 & 0,004 & 0,000 \\ \text { F_01_F_Tor } & 0,156 & 0,007 & 0,000 \\ \text { F_02_F_Tor } & 0,112 & 0,005 & 0,000 \\ \text { F_03_F_Tor } & 0,100 & 0,005 & 0,000 \\ \text { F_04_F_Tor } & 0,101 & 0,005 & 0,000 \\ \text { F_05_F_Tor } & 0,180 & 0,008 & 0,000\end{array}$


6. számú melléklet: Az online iskolakezdö méröeszközcsomag mérési útmutatója, 2016 öszi adatfelvétel
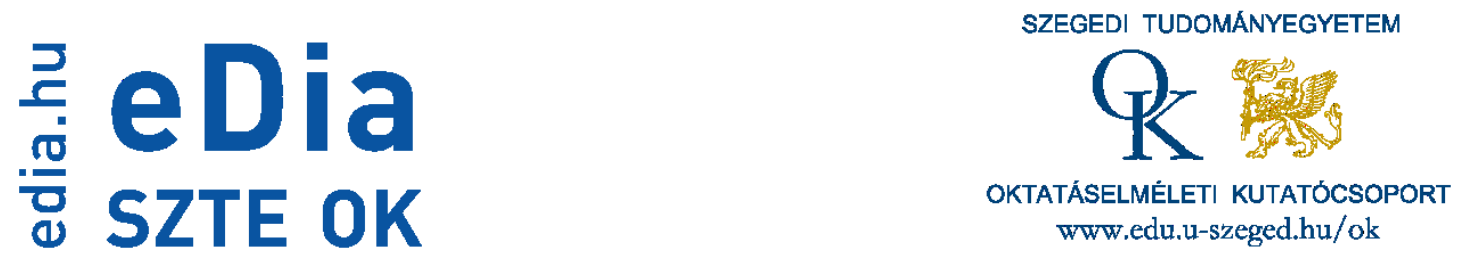

eDia-ÚJ GENERÁCIÓS ISKOLAKÉSZÜLTSÉG MÉRŐESZKÖZ-CSOMAG

\section{Mérési útmutató}

Köszönjük, hogy az Ön iskolája is részt vesz az eDia rendszer fejlesztésében. A rendszerbe belépő első osztályos diákok induló képességszintjének mérése céljából a 2015/16-os tanévtől kezdve egy új generációs iskolakezdés mérőeszköz-csomagot ajánlunk fel az iskolák számára. A mérőeszközcsomag tesztjei a következő készségek, képességek mérését valósítják meg:

- Géphasználat

- Matematika

- Olvasási előkészségek

- Vizuális memória

- Feladattartás

- Induktív gondolkodás

\section{HOGYAN ÉS HOL ÉRHETŐEK EL A TESZTEK?}

A tesztek a következő webcímen érhetőek el: edia.hu/evf1

A teljes tesztcsomag felvételére három mérési alkalom szükséges:

- fejlesztéssel egybekötött játékos egér és billentyüzethasználat (1 tanóra; elérhető: 2016. október 04-től);

- matematika és olvasási előképességek teszt (1 tanóra; elérhető: 2016. október 06-tól);

- rövidtávú memória, feladattartás és induktív gondolkodás teszt (1 tanóra; elérhető: 2016. október 06-tól).

Fontos, hogy a tanulók ebben a sorrendben oldják meg a teszteket, mivel így elöször játékos feladatok megoldásán keresztül gyakorolhatják a diákok a tesztek megoldásához szükséges egérkezelési müveleteket. 


\section{MILYEN ELŐKÉSZÜLETEK SZÜKSÉGESEK A TESZTELÉS MEGKEZDÉSE ELÖTT?}

A munka megkezdése előtt kérjük, hogy...

○ a termet készítse elö, a gépeket kapcsolja be, minden gépen indítson el egy internetes böngészőt (Mozilla Firefox vagy Google Chrome - más böngésző nem használható). Fontos, hogy a gépeken a böngészőprogramok legfrissebb változatai legyenek (pl.: Firefox -> Súgó -> A Firefox névjegye; Google Chrome esetén is hasonló az eljárás). A nyár folyamán nagymértékü fejlesztés valósult meg a rendszerben, ezért a böngészők frissítése elengedhetetlen a tesztek, a feladatok zavartalan müködéséhez és futásához.

○ amennyiben az iskola internet sávszélessége nagyon kicsi vagy túlterhelt, lehetőség van a tesztek proxy szerveren keresztüli kitöltésére, melynek beállítása a teszt kitöltése előtt szükséges. Az erre vonatkozó információk a teszt linkjének nyitóoldalán elérhetőek, valamint egy útmutatót is mellékelünk a proxy szerver használatához. Nagyon fontos, hogy a proxy szerver alkalmazása esetén mindenképp jussanak el a proxy szerverként szolgáló számítógépen a nyitó oldalig, ahol a diákoknak a mérési azonosítót kell beírn1.

○ minden gépen töltse be és indítsa el a feladatsort! Ellenőrizze, hogy a böngésző $100 \%$-os nagyításban legyen.

- Mivel jelen mérésünk az 1. évfolyamra készült, a tesztek feladatai nem olvashatóak, csak meghallgathatóak, ezért kérjük, biztosítsanak fülhallgatót a kisiskolás diákok számára. A mérés megkezdése előtt ellenőrizze a fejhallgatókat, hogy megfelelően müködnek-e!

○ Kérem, készítse elő a tanulók mérési azonosítószámait, majd a terembe való beérkezésük után gépelje be a gyerekek megfelelő mérési azonosítóit!

○ A hiányzó tanulók mérési azonosítóját más nem használhatja!

Kérjük, a mérés során tett észrevételeinek, javaslatainak lejegyzésével segítse további munkánkat! Figyelje meg, hogy...

○ milyen kérdéseket tesznek fel a tanulók a feladatokkal, a megoldás módjával kapcsolatban!

○ milyen egyéb észrevételeket, javaslatokat tud megfogalmazni a feladatokra és az adatfelvételre nézve?

\section{MEDDIG LEHET HASZNÁLNI A TESZTEKET?}

Lehetőségüknek megfelelően az öszi szünetig (2016. október 28-ig) bonyolítsák le az adatfelvételt.

\section{HOL ÉRHETŐEK EL - SEGÍTSÉGKÉRÉS ESETÉN - AZ SZTE OK KUTATÁSSZERVEZŐ CSOPORT MUNKATÁRSAI?}

Amennyiben a kutatással vagy az adatfelvétellel kapcsolatban bármilyen kérdés, probléma merülne fel, forduljanak hozzánk bizalommal a kutatásszervezö csoport munkatársaihoz a 62/544-628, 62/343-063 illetve a 62/343-487-es telefonszámokon! Ha kíváncsiak, hogyan néznek ki a tesztjeink, ajánljuk figyelmébe demo tesztjeinket, melyek az edia.hu/ok internetes oldalon érhetőek el. 
Köszönjük, hogy munkájával támogatja a kutatásunk és az eDia rendszer felépitésének megvalósitását!

Szeged, 2016. október 03. 
7. számú melléklet: Az elsö osztályos tanulók körében, 2016-ban rögzített fonématudatosság teszt elkülönités mutatói

Megjegyzések a feladatok elnevezéséhez: F_Szh: szókezdő hang azonosítása; F_Szeg: fonémaszegmentálás; F_Tor: fonématörlés; F_szin: fonémaszintézis; F_Az: fonémaazonosítás; F_Hh: fonémaazonosítás a hívóhang helyének meghatározásával

\begin{tabular}{|c|c|c|c|c|}
\hline Item & Átlag & Szórás & $\begin{array}{l}\text { Elkülönítés } \\
\text { mutató }\end{array}$ & $\begin{array}{l}\text { Cronbach- } \alpha \text { változása az } \\
\text { item törlése esetén }\end{array}$ \\
\hline F_01_F_Az & 0,71 & 0,453 & 0,076 & 0,903 \\
\hline F_02_F_Az & 0,75 & 0,431 & 0,325 & 0,900 \\
\hline F_03_F_Az & 0,49 & 0,500 & 0,396 & 0,899 \\
\hline F_04_F_Az & 0,66 & 0,473 & 0,298 & 0,900 \\
\hline F_05_F_Az & 0,55 & 0,497 & 0,520 & 0,897 \\
\hline F_06_F_Az & 0,44 & 0,497 & 0,306 & 0,900 \\
\hline F_07_F_Az & 0,55 & 0,497 & 0,509 & 0,897 \\
\hline F_08_F_Az & 0,52 & 0,500 & 0,477 & 0,898 \\
\hline F_09_F_Az & 0,21 & 0,408 & 0,076 & 0,903 \\
\hline F_10_F_Az & 0,54 & 0,498 & 0,367 & 0,900 \\
\hline F_11_F_Hh & 0,55 & 0,498 & 0,476 & 0,898 \\
\hline F_12_F_Hh & 0,50 & 0,500 & 0,366 & 0,900 \\
\hline F_13_F_Hh & 0,39 & 0,488 & 0,424 & 0,899 \\
\hline F_14_F_Hh & 0,40 & 0,490 & 0,426 & 0,899 \\
\hline F_15_F_Hh & 0,43 & 0,496 & 0,530 & 0,897 \\
\hline F_16_F_Hh & 0,44 & 0,496 & 0,491 & 0,898 \\
\hline F_17_F_Hh & 0,42 & 0,494 & 0,460 & 0,898 \\
\hline F_18_F_Hh & 0,55 & 0,497 & 0,567 & 0,896 \\
\hline F_19_F_Hh & 0,56 & 0,497 & 0,589 & 0,896 \\
\hline F_20_F_Hh & 0,46 & 0,499 & 0,531 & 0,897 \\
\hline F_21_F_Szeg & 0,48 & 0,500 & 0,536 & 0,897 \\
\hline F_22_F_Szeg & 0,33 & 0,470 & 0,502 & 0,897 \\
\hline F_23_F_Szeg & 0,47 & 0,499 & 0,508 & 0,897 \\
\hline F_24_F_Szeg & 0,11 & 0,310 & 0,381 & 0,899 \\
\hline F_25_F_Szeg & 0,26 & 0,439 & 0,528 & 0,897 \\
\hline F_26_F_Szh & 0,52 & 0,500 & 0,533 & 0,897 \\
\hline
\end{tabular}




\begin{tabular}{lllll} 
F_27_F_Szh & 0,51 & 0,500 & 0,456 & 0,898 \\
F_28_F_Szh & 0,56 & 0,497 & 0,507 & 0,897 \\
F_29_F_Szh & 0,47 & 0,499 & 0,455 & 0,898 \\
F_30_F_Szh & 0,56 & 0,497 & 0,529 & 0,897 \\
F_31_F_Szin & 0,72 & 0,447 & 0,477 & 0,898 \\
F_32_F_Szin & 0,61 & 0,488 & 0,523 & 0,897 \\
F_33_F_Szin & 0,75 & 0,434 & 0,501 & 0,898 \\
F_34_F_Szin & 0,80 & 0,399 & 0,530 & 0,897 \\
F_35_F_Szin & 0,81 & 0,395 & 0,508 & 0,898 \\
F_36_F_Tor & 0,72 & 0,451 & 0,446 & 0,898 \\
F_37_F_Tor & 0,76 & 0,425 & 0,482 & 0,898 \\
F_38_F_Tor & 0,79 & 0,410 & 0,495 & 0,898 \\
F_39_F_Tor & 0,68 & 0,467 & 0,441 & 0,898 \\
F_40_F_Tor & 0,77 & 0,423 & 0,507 & 0,897 \\
\hline
\end{tabular}




\section{Beleegyező nyilatkozat}

Kijelentem, hogy a SZTE Oktatáselméleti Kutatócsoport által végzendő, az óvodai mérés-értékelési folyamatot kiegészítő online tesztekben engedélyezem gyermekem részvételét. A vizsgálat jellegéről annak megkezdése előtt kielégítő tájékoztatást kaptam.

Tudomásul veszem, hogy a gyermekem azonosítására alkalmas személyi adatokat bizalmasan kezelik. Hozzájárulok ahhoz, hogy a vizsgálat során a felvett, gyermekem azonosítására nem alkalmas adatok más kutatók számára is hozzáférhetők legyenek.

A méréshez való hozzájárulás jeleként kitöltöm a dokumentum következő oldalán lévő táblázatot, melyben rögzítem gyermekem csoportját, nevét és születési dátumát.

A táblázatban igen (I) vagy nem (N) jelzést teszek arra vonatkozóan, hogy engedélyezem-e a Szegedi Tudományegyetem Oktatáselméleti Kutatócsoportjának munkatársai számára kép és hangfelvétel készítését gyermekemről, mely magát a tesztelést és annak menetét szemléltet1.

Az Oktatáselméleti Kutatócsoport az elkészült felvételeket kiadványokhoz, webes megjelenésekhez kizárólag nonprofit módon használja fel. A felvételek alapján készült videókkal, kiadványokkal a kutatócsoport szemléltetni kívánja a gyermekek számítógép alapú tesztelésen szerzett élményeit.

Email címemre rövid időn belül a kutatócsoport egy háttérkérdőívet küld, melybe gyermekem azonosítójával fogok tudni belépn1. A háttérkérdőívben anonim módon olyan háttéradatokat adok meg, melyek kapcsolatba hozhatók gyermekem teszten nyújtott teljesítményével.

Fenntartom a jogot arra, hogy a vizsgálat során annak folytatásától bármikor elállhassak.

Tudomásul veszem, hogy a vizsgálat eredményéról külön laboratóriumi lelet, orvosi zárójelentés nem készül.

Kelt: Szeged, 2015. december 22. 


\begin{tabular}{|c|c|c|c|c|c|}
\hline Csoport & Név & Születési dátum & \begin{tabular}{|c}
$\begin{array}{l}\text { Vágókép készitísébe } \\
\text { történő beleegyezés } \\
(1 / N)\end{array}$ \\
\end{tabular} & A szülló email címe & A szülö aláírása \\
\hline pl. Mackó & pl. Teszt Elek & pl. 2011.04.08. & pl. 1 & pl. elek@elek.hu & \\
\hline & & & & & \\
\hline & & & & & \\
\hline & & & & & \\
\hline & & & & & \\
\hline & & & & & \\
\hline & & & & & \\
\hline & & & & & \\
\hline & & & & & \\
\hline & & & & & \\
\hline & & & & & \\
\hline & & & & & \\
\hline & & & & & \\
\hline & & & & & \\
\hline
\end{tabular}


9. számú melléklet: Az óvodás gyermekek körében rögzített fonológiai tudatosság teszt statisztikai mutatói

Megjegyzések a feladatok elnevezéséhez: Sz_Szin: szótagszintézis; Sz_Szeg: szótagszegmentálás; Sz_Tor: szótagtörlés; F_Szh: szókezdő hang azonosítása; F_Szeg: fonémaszegmentálás; F_Tor: fonématörlés; F_szin: fonémaszintézis; F_Az: fonémaazonosítás; F_Hh: fonémaazonosítás a hívóhang helyének meghatározásával

\begin{tabular}{|c|c|c|c|c|}
\hline Item & Átlag & Szórás & $\begin{array}{c}\text { Elkülönítés } \\
\text { mutató }\end{array}$ & $\begin{array}{l}\text { Cronbach- } \alpha \text { változása az } \\
\text { item törlése esetén }\end{array}$ \\
\hline F_01_Sz_Szin & 0,73 & 0,444 & $-0,006$ & 0,829 \\
\hline F_02_Sz_Szin & 0,72 & 0,447 & 0,331 & 0,822 \\
\hline F_03_Sz_Szin & 0,36 & 0,480 & 0,222 & 0,824 \\
\hline F_04_Sz_Szin & 0,65 & 0,476 & 0,188 & 0,825 \\
\hline F_05_Sz_Szin & 0,40 & 0,490 & 0,388 & 0,820 \\
\hline F_06_Sz_Szeg & 0,45 & 0,499 & 0,239 & 0,824 \\
\hline F_07_Sz_Szeg & 0,42 & 0,494 & 0,390 & 0,820 \\
\hline F_08_Sz_Szeg & 0,42 & 0,495 & 0,357 & 0,821 \\
\hline F_09_Sz_Szeg & 0,25 & 0,432 & $-0,025$ & 0,830 \\
\hline F_10_Sz_Szeg & 0,47 & 0,500 & 0,184 & 0,826 \\
\hline F_11_Sz_Tor & 0,45 & 0,498 & 0,255 & 0,824 \\
\hline F_12_Sz_Tor & 0,43 & 0,495 & 0,221 & 0,825 \\
\hline F_13_Sz_Tor & 0,28 & 0,450 & 0,289 & 0,822 \\
\hline F_14_Sz_Tor & 0,32 & 0,466 & 0,348 & 0,821 \\
\hline F_15_Sz_Tor & 0,29 & 0,457 & 0,395 & 0,820 \\
\hline F_16_F_Az & 0,32 & 0,467 & 0,353 & 0,821 \\
\hline F_17_F_Az & 0,31 & 0,462 & 0,307 & 0,822 \\
\hline F_18_F_Az & 0,48 & 0,500 & 0,419 & 0,819 \\
\hline F_19_F_Az & 0,39 & 0,489 & 0,475 & 0,817 \\
\hline F_20_F_Az & 0,36 & 0,480 & 0,385 & 0,820 \\
\hline F_21_F_Az & 0,27 & 0,444 & 0,360 & 0,821 \\
\hline F_22_F_Az & 0,24 & 0,426 & 0,327 & 0,821 \\
\hline
\end{tabular}




\begin{tabular}{|c|c|c|c|c|}
\hline F_23_F_Az & 0,12 & 0,328 & 0,240 & 0,823 \\
\hline F_24_F_Az & 0,05 & 0,221 & 0,116 & 0,825 \\
\hline F_25_F_Az & 0,06 & 0,245 & 0,178 & 0,824 \\
\hline F_26_F_Hh & 0,48 & 0,500 & 0,414 & 0,819 \\
\hline F_27_F_Hh & 0,36 & 0,480 & 0,445 & 0,818 \\
\hline F_28_F_Hh & 0,41 & 0,493 & 0,423 & 0,819 \\
\hline F_29_F_Hh & 0,40 & 0,491 & 0,392 & 0,820 \\
\hline F_30_F_Hh & 0,39 & 0,489 & 0,380 & 0,820 \\
\hline F_31_F_Hh & 0,72 & 0,451 & 0,396 & 0,820 \\
\hline F_32_F_Hh & 0,53 & 0,500 & 0,452 & 0,818 \\
\hline F_33_F_Hh & 0,67 & 0,472 & 0,459 & 0,818 \\
\hline F_34_F_Hh & 0,81 & 0,390 & 0,438 & 0,819 \\
\hline F_35_F_Hh & 0,80 & 0,400 & 0,396 & 0,820 \\
\hline F_36_F_Szeg & 0,73 & 0,445 & 0,322 & 0,822 \\
\hline F_37_F_Szeg & 0,77 & 0,422 & 0,412 & 0,819 \\
\hline F_38_F_Szeg & 0,78 & 0,414 & 0,513 & 0,817 \\
\hline F_39_F_Szeg & 0,66 & 0,476 & 0,371 & 0,820 \\
\hline F_40_F_Szeg & 0,79 & 0,407 & 0,414 & 0,819 \\
\hline F_41_F_Szh & 0,25 & 0,435 & 0,153 & 0,825 \\
\hline F_42_F_Szh & 0,26 & 0,442 & 0,247 & 0,823 \\
\hline F_43_F_Szh & 0,23 & 0,422 & 0,275 & 0,822 \\
\hline F_44_F_Szh & 0,30 & 0,459 & 0,336 & 0,821 \\
\hline F_45_F_Szh & 0,32 & 0,468 & 0,374 & 0,820 \\
\hline F_46_F_Szin & 0,96 & 0,206 & 0,235 & 0,823 \\
\hline F_47_F_Szin & 0,96 & 0,191 & 0,144 & 0,824 \\
\hline F_48_F_Szin & 0,69 & 0,462 & 0,304 & 0,822 \\
\hline F_49_F_Szin & 0,90 & 0,306 & 0,274 & 0,823 \\
\hline F_50_F_Szin & 0,97 & 0,166 & 0,134 & 0,824 \\
\hline F_51_F_Tor & 0,85 & 0,359 & 0,219 & 0,823 \\
\hline F_52_F_Tor & 0,84 & 0,371 & 0,315 & 0,821 \\
\hline
\end{tabular}




\begin{tabular}{lllll} 
F_53_F_Tor & 0,38 & 0,487 & 0,169 & 0,825 \\
F_54_F_Tor & 0,64 & 0,480 & 0,443 & 0,819 \\
F_55_F_Tor & 0,42 & 0,495 & 0,125 & 0,827 \\
\hline
\end{tabular}


10. számú melléklet: Az óvodai mintán rögzített fonológiai tudatosság teszt megerösitő faktorelemzésének eredményei

Megjegyzések a feladatok elnevezéséhez: Sz_Szin: szótagszintézis; Sz_Szeg: szótagszegmentálás; Sz_Tor: szótagtörlés; F_Szh: szókezdő hang azonosítása; F_Szeg: fonémaszegmentálás; F_Tor: fonématörlés; F_szin: fonémaszintézis; F_Az: fonémaazonosítás; F_Hh: fonémaazonosítás a hívóhang helyének meghatározásával

\begin{tabular}{|c|c|c|c|}
\hline & Estimate & S.E. & P-VALUE \\
\hline F_01_Sz_Szin & 0,037 & 0,00 & 0,000 \\
\hline F_02_Sz_Szin & 0,191 & 0,02 & 0,000 \\
\hline F_03_Sz_Szin & 0,073 & 0,01 & 0,000 \\
\hline F_01_Sz_Szeg & 0,088 & 0,01 & 0,000 \\
\hline F_02_Sz_Szeg & 0,080 & 0,01 & 0,000 \\
\hline F_03_Sz_Szeg & 0,116 & 0,01 & 0,000 \\
\hline F_04_Sz_Szeg & 0,109 & 0,01 & 0,000 \\
\hline F_01_Sz_Tor & 0,115 & 0,01 & 0,000 \\
\hline F_02_Sz_Tor & 0,115 & 0,01 & 0,000 \\
\hline F_03_Sz_Tor & 0,171 & 0,02 & 0,000 \\
\hline F_01_F_Az & 0,195 & 0,02 & 0,000 \\
\hline F_02_F_Az & 0,178 & 0,02 & 0,000 \\
\hline F_03_F_Az & 0,135 & 0,01 & 0,000 \\
\hline F_04_F_Az & 0,167 & 0,02 & 0,000 \\
\hline F_05_F_Az & 0,133 & 0,01 & 0,000 \\
\hline F_06_F_Az & 0,120 & 0,01 & 0,000 \\
\hline F_01_F_Hh & 0,237 & 0,02 & 0,000 \\
\hline F_02_F_Hh & 0,242 & 0,02 & 0,000 \\
\hline F_03_F_Hh & 0,185 & 0,02 & 0,000 \\
\hline F_04_F_Hh & 0,194 & 0,02 & 0,000 \\
\hline F_05_F_Hh & 0,174 & 0,02 & 0,000 \\
\hline F_06_F_Hh & 0,193 & 0,02 & 0,000 \\
\hline F_07_F_Hh & 0,196 & 0,02 & 0,000 \\
\hline F_08_F_Hh & 0,177 & 0,02 & 0,000 \\
\hline F_09_F_Hh & 0,192 & 0,02 & 0,000 \\
\hline $\mathrm{F}_{-} 10 \_\mathrm{F} \_\mathrm{Hh}$ & 0,192 & 0,02 & 0,000 \\
\hline F_01_F_Szeg & 0,132 & 0,02 & 0,000 \\
\hline
\end{tabular}




\begin{tabular}{llll} 
F_02_F_Szeg & 0,087 & 0,01 & 0,000 \\
F_03_F_Szeg & 0,145 & 0,02 & 0,000 \\
F_01_F_Szh & 0,171 & 0,02 & 0,000 \\
F_02_F_Szh & 0,159 & 0,02 & 0,000 \\
F_03_F_Szh & 0,175 & 0,02 & 0,000 \\
F_04_F_Szh & 0,177 & 0,02 & 0,000 \\
F_05_F_Szh & 0,197 & 0,02 & 0,000 \\
F_01_F_Szin & 0,156 & 0,01 & 0,000 \\
F_02_F_Szin & 0,190 & 0,02 & 0,000 \\
F_03_F_Szin & 0,140 & 0,01 & 0,000 \\
F_04_F_Szin & 0,086 & 0,01 & 0,000 \\
F_05_F_Szin & 0,107 & 0,01 & 0,000 \\
F_01_F_Tor & 0,170 & 0,01 & 0,000 \\
F_02_F_Tor & 0,124 & 0,01 & 0,000 \\
F_03_F_Tor & 0,088 & 0,01 & 0,000 \\
F_04_F_Tor & 0,102 & 0,01 & 0,000 \\
F_05_F_Tor & 0,189 & 0,02 & 0,000 \\
\hline
\end{tabular}

